\title{
ipen
}

INSTITUTO DE PESQUISAS ENERGÉTICAS E NUCLEARES

Autarquia associada à Universidade de São Paulo

\section{DESENVOLVIMENTO DE CONJUNTOS ELETRODO-MEMBRANA-ELETRODO PARA CÉLULAS A COMBUSTÍVEL A MEMBRANA TROCADORA DE PRÓTONS (PEMFC) POR IMPRESSÃO À TELA}

ALEXANDRE BODART DE ANDRADE

Dissertação apresentada como parte dos requisitos para obtenção do Grau de Mestre em Ciências na Área de Tecnologia Nuclear - Materiais.

Orientador:

Dr. Marcelo Linardi

SÃO PAULO 


\section{DEDICATÓRIA}

Ao meu anjo na Terra, minha esposa Fabíola, que acreditou neste sonho quando não havia um horizonte tão claro e que agora, no final das contas e no começo dos contos, sabe que hoje somos felizes os dois, e que continuaremos sendo amanhã e depois.

E que assim seja! 


\section{AGRADECIMENTOS}

O meu sonho de estudar células a combustível e de estar perto de onde as informações mais recentes sobre este assunto são discutidas foi realizado com a execução deste trabalho e com a minha participação no dia-a-dia das pesquisas do Programa de Células a Combustível do IPEN. Isto não seria possível sem a oportunidade dada pelo Prof. Dr. Marcelo Linardi, que além dos ensinamentos em sala de aula enriqueceu este cenário com suas orientações. Aqui ficam registrados meus sinceros agradecimentos a ele.

Aproveito para agradecer ao IPEN (Instituto de Pesquisas Energéticas e Nucleares) e ao PROH2 (Programa Brasileiro de Células a Combustível e Hidrogênio) por darem todo o suporte estrutural necessário ao desenvolvimento da pesquisa, seja na providência de infra-estrutura de laboratório, de matériaprima para o trabalho ou mesmo de ajuda em meu sustento nesta cidade.

O caminho percorrido teria sido mais árduo sem a solidariedade, as informações, as discussões técnicas e os momentos de descontração vividos com os funcionários e estudantes do Programa de Células a Combustível. Agradeço a todos pela ajuda e principalmente pela amizade desenvolvida neste período. Sem demérito aos demais, quero especialmente agradecer à Dr. Martha Mora Bejarano e aos mestres Edgar Ferrari da Cunha e Eric Robalinho que dentro deste grupo estiveram um pouco mais próximos, inclusive dividindo alguns objetivos de pesquisa.

Agradeço ainda ao grupo de pesquisas do Hydrogen Institute for Applied Technology (HIAT) de Schwerin, na Alemanha, que facilitou o início desta pesquisa com suas colaborações

Muito obrigado à minha família, por ter apoiado minha decisão e entendido meu distanciamento físico. Mas acima de tudo, obrigado pelo carinho e pelos valores que me ensinaram até aqui.

À minha doce esposa, obrigado por ter enfrentado a barra desta jornada e ainda assim continuar com suas demonstrações de amor e carinho. 


\section{EPÍGRAFE}

“... para que Deus vos deu a inteligência e a ciência, senão para repartir com vossos irmãos, para os adiantar no caminho da alegria e da felicidade eterna."

São Luís, Santo Agostinho. 


\title{
DESENVOLVIMENTO DE CONJUNTOS ELETRODO-MEMBRANA-ELETRODO PARA CÉLULAS A COMBUSTÍVEL A MEMBRANA TROCADORA DE PRÓTONS (PEMFC) POR IMPRESSÃO À TELA
}

\author{
Alexandre Bodart de Andrade
}

RESUMO

O processo de Impressão à Tela foi desenvolvido neste trabalho para ser aplicável à deposição de camadas catalíticas em eletrólitos utilizados em PEMFC. Inicialmente foram construídos conjuntos eletrodos-membrana (MEAs) de $25 \mathrm{~cm}^{2}$ de área ativa e comparados com outros produzidos pelo método de Aspersão. Os dois métodos produziram MEAs que apresentaram densidades de corrente acima de $600 \mathrm{~mA} \cdot \mathrm{cm}^{-2}$ a $600 \mathrm{mV}$. Foi conduzido um estudo para o aumento de escala do MEA para $144 \mathrm{~cm}^{2}$ de área ativa. Para este fim, foi projetada uma célula para abrigar os MEAs destas dimensões. Neste projeto, o perfil dos canais de distribuição de gás foi desenvolvido através da ferramenta de fluido dinâmica computacional "Comsol Multiphysics", sendo que, para o projeto das placas componentes da célula foi utilizado o "AutoCAD". Os MEAs de $144 \mathrm{~cm}^{2}$ confeccionados por Aspersão e por Impressão à Tela foram confrontados com MEAs comerciais de iguais dimensões. Estes apresentaram melhor desempenho a $600 \mathrm{mV}$, entretanto são mais custosos que a solução desenvolvida neste estudo. O novo método apresentou-se adequado para a confecção de MEAs de baixo custo de diferentes geometrias e para a produção de lotes a serem utilizados em pequenos módulos de potência. 


\title{
DEVELOPMENT OF ELECTRODE-MEMBRANE-ELECTRODE ASSEMBLIES FOR PROTON EXCHANGE MEMBRANE FUEL CELLS (PEMFC) BY SIEVE PRINTING
}

\author{
Alexandre Bodart de Andrade
}

\begin{abstract}
The Sieve Printing process was studied in this work to apply the catalyst layers onto electrolytes utilized in PEMFC. Initially, $25 \mathrm{~cm}^{2}$ active area MEAs were built for comparison with others MEAs produced by the Spray technique. The two methods produced MEAs that showed current densities higher than $600 \mathrm{~mA} . \mathrm{cm}^{-2}$ at $600 \mathrm{mV}$. A scaling up study for $144 \mathrm{~cm}^{2}$ of active area MEAs was carried out. For this purpose, a new cell had to be projected for shelter the MEAs in such dimensions. The profile of the gas distribution channels was developed through the computational fluid dynamic tool "Comsol Multiphysics". For the design of the bipolar plates of the cell the "AutoCAD" was used. The $144 \mathrm{~cm}^{2}$ MEAs made by Spray and by Sieve Printing methods were confronted with commercials MEAs ones of equal dimensions. These commercials MEAs presented better performance at $600 \mathrm{mV}$, however they were more costly than the solution developed in this study. The new method was showed to be adequate to fabricate low cost MEAs of different geometries and to produce any amount of MEAs for small scale stacks (up to $10 \mathrm{~kW}$ ).
\end{abstract}




\section{SUMÁRIO}

Página

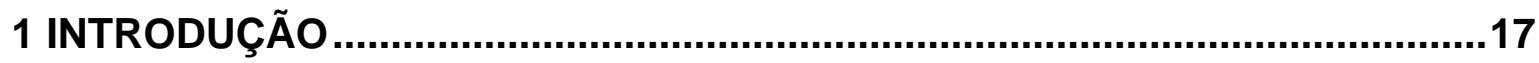

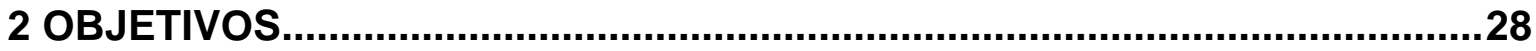

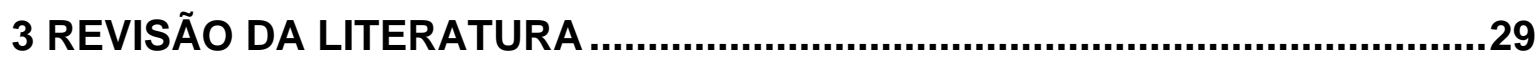

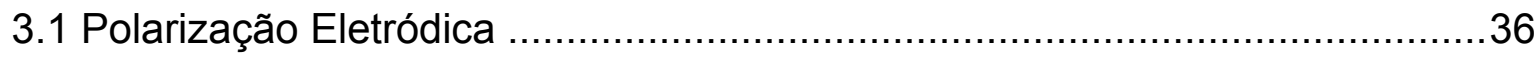

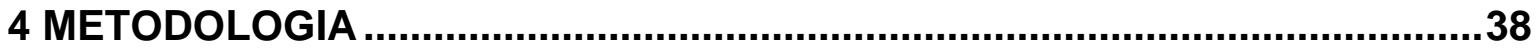

4.1 Microscopia Eletrônica de Varredura (MEV) ………..................................... 38

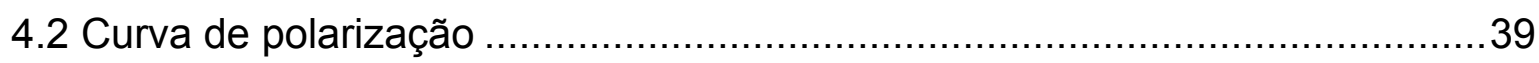

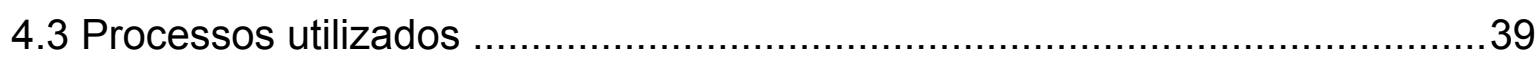

4.3.1 Confecção de MEAs e montagem de PEMFC .........................................39

4.3.2 Tratamento de Membrana (Aspersão) …………..................................... 41

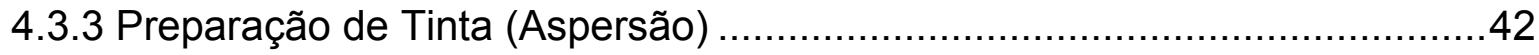

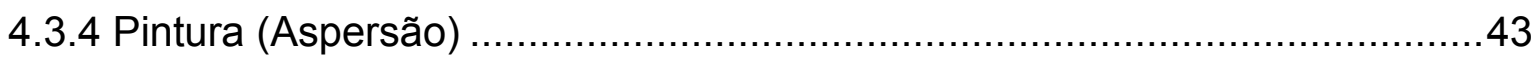

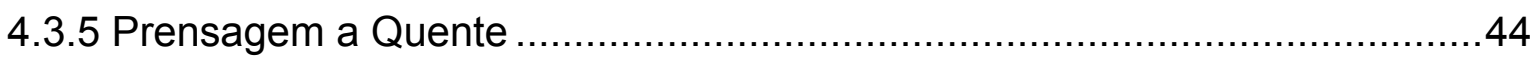

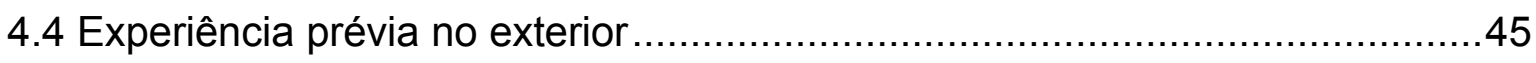

4.5 Procedimentos para o estabelecimento do processo de Impressão ................46

4.6 Comparação entre os métodos de Impressão à Tela e Aspersão ....................49

4.7 Aumento de escala dos MEAs produzidos ...................................................

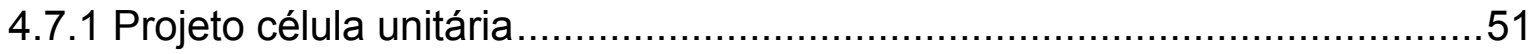

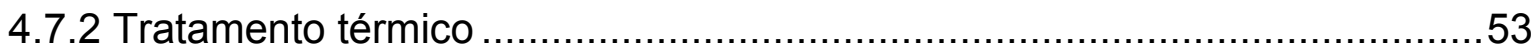

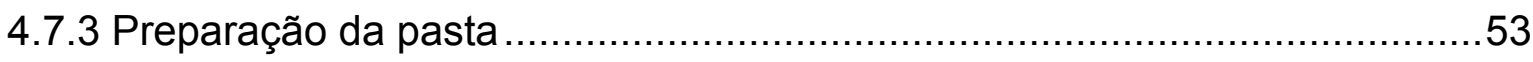

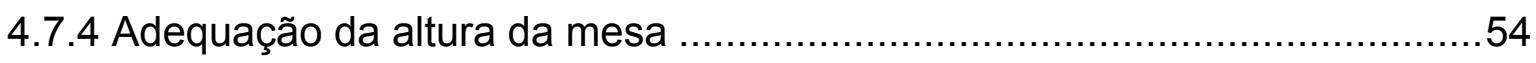

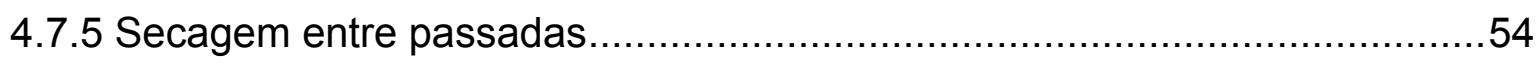

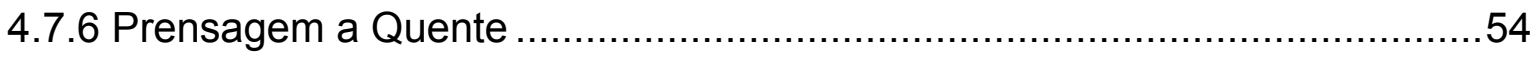

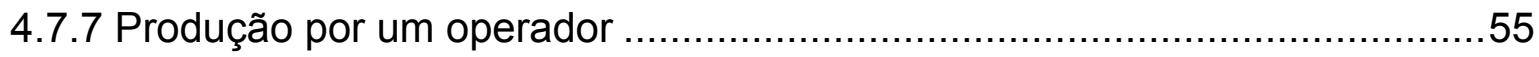

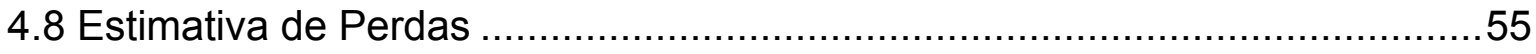

4.9 Curva de Polarização - Impressão à Tela vs Aspersão vs Comercial ..............55

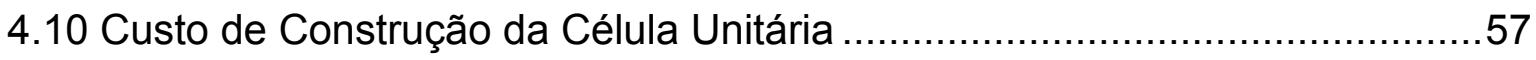

4.11 Custo de Produção do MEA por Impressão à Tela ......................................57

5 RESULTADOS E DISCUSSÕES.............................................................59 
5.1 Tratamento Térmico da Membrana $\left(25 \mathrm{~cm}^{2}\right)$ .59

5.2 Adição da solução de Nafion ${ }^{\circledR}$ e do Solvente $\left(25 \mathrm{~cm}^{2}\right)$.................................60

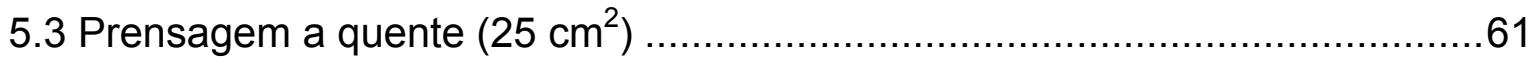

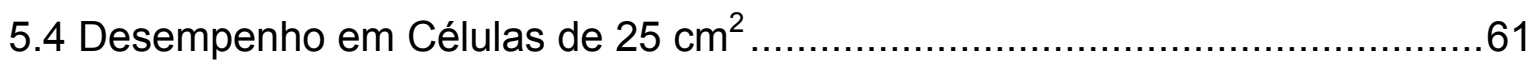

$5.5 \mathrm{MEV} 25 \mathrm{~cm}^{2}$ - Impressão à Tela vs Aspersão ………............................... 71

5.6 Curva de Polarização $25 \mathrm{~cm}^{2}$ - Impressão à Tela vs Aspersão......................73

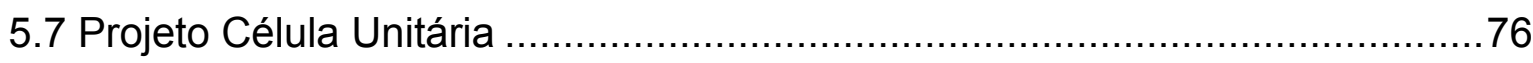

5.8 Tratamento Térmico da Membrana $\left(144 \mathrm{~cm}^{2}\right)$..............................................8.

5.9 Parâmetros da Preparação da Pasta, da Máquina e da Prensagem ...............84

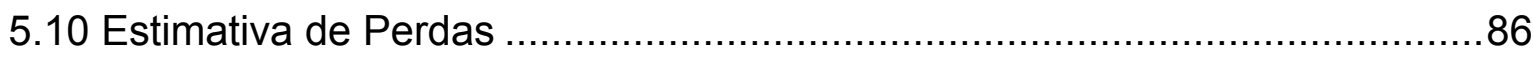

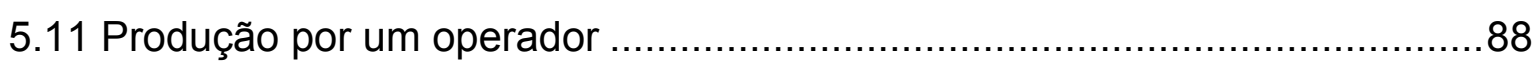

5.12 Desempenho $144 \mathrm{~cm}^{2}$ - Impressão à Tela vs Aspersão vs Comercial ..........89

5.13 Custo da Célula Unitária de $144 \mathrm{~cm}^{2}$ de área ativa.....................................96

5.14 Custo de Produção do MEA de $144 \mathrm{~cm}^{2}$ por Impressão à Tela ....................97

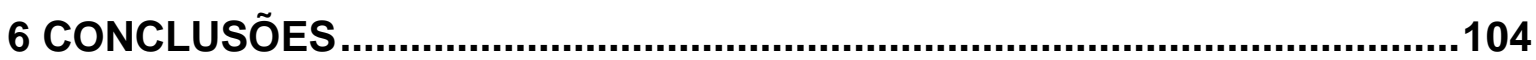

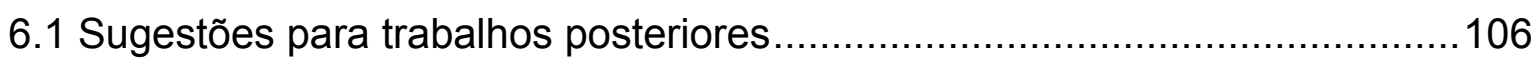

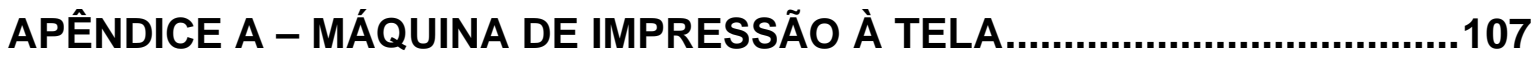

APÊNDICE B - RESULTADOS DO PERFIL PQ20 …...................................108

APÊNDICE C - RESULTADOS DO PERFIL PQ15 ……..................................109

APÊNDICE D - RESULTADOS DO PERFIL PT.........................................110

APÊNDICE E - VISTA FRONTAL - GRAFITE - PERFIL QUADRADO ...........111

APÊNDICE F - VISTA POSTERIOR - GRAFITE - PERFIL QUADRADO.........112

APÊNDICE G - VISTA DE TOPO - GRAFITE - PERFIL QUADRADO .............113

APÊNDICE H - VISTA FRONTAL - GRAFITE - PERFIL TRAPEZOIDAL ........114

APÊNDICE I - VISTA POSTERIOR - GRAFITE - PERFIL TRAPEZOIDAL ....115

APÊNDICE J - VISTA DE TOPO - GRAFITE - PERFIL TRAPEZOIDAL .........116

APÊNDICE K - VISTA FRONTAL - COBRE.............................................117

APÊNDICE L - VISTA FRONTAL - ALUMÍNIO …......................................118

APÊNDICE M - VISTA POSTERIOR - ALUMÍNIO ……................................119

APÊNDICE N - VISTA DE TOPO - ALUMÍNIO ............................................120

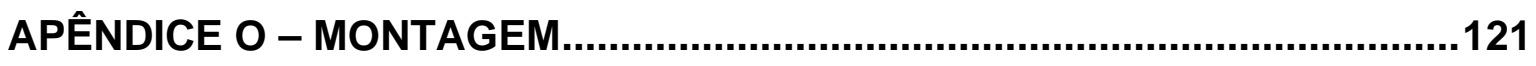

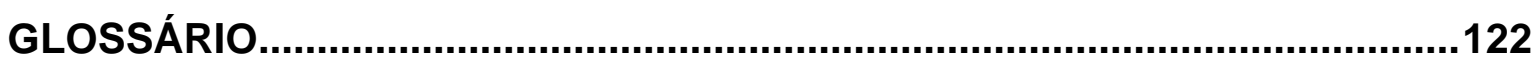

REFERÊNCIAS BIBLIOGRÁFICAS......................................................123 


\section{LISTA DE TABELAS}

TABELA 1 - Principais tipos de Célula a Combustível................................... 17

TABELA 2 - Confecção de MEAs e montagem de PEMFC ............................40

TABELA 3 - Tratamento de Membrana (Aspersão) .................................. 41

TABELA 4 - Preparação de Tinta (Aspersão) ...........................................42

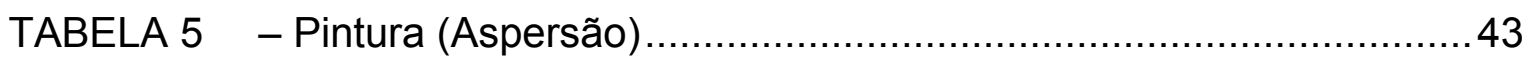

TABELA 6 - Prensagem a Quente...................................................... 44

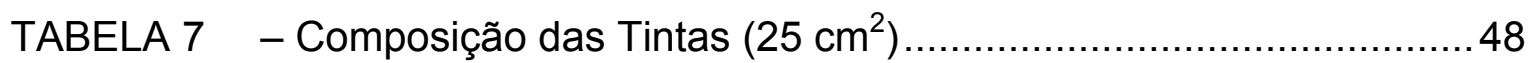

TABELA 8 - Resultados do Tratamento Térmico $\left(25 \mathrm{~cm}^{2}\right)$................................. 59

TABELA 9 - Resultados da adição da solução de Nafion ${ }^{\circledR}$ e do solvente .........60

TABELA 10 - Cargas calculadas - Impressão à Tela $\left(25 \mathrm{~cm}^{2}\right)$...................... 62

TABELA 11 - Potencial de Operação - Impressão à Tela $\left(25 \mathrm{~cm}^{2}\right)$.................... 62

TABELA 12 - Potência Máxima - Impressão à Tela $\left(25 \mathrm{~cm}^{2}\right) \ldots \ldots \ldots \ldots \ldots \ldots \ldots \ldots . . . . . . . . . . .68$

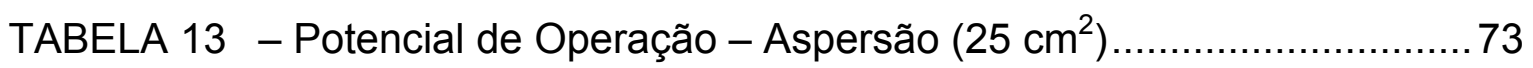

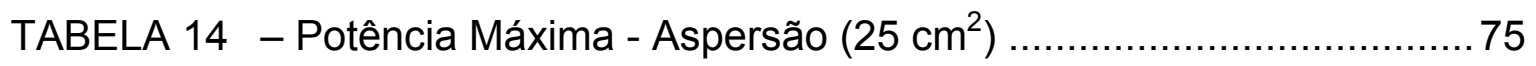

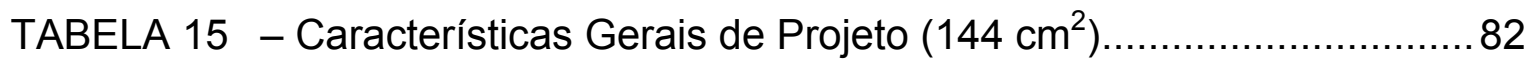

TABELA 16 - Resultados do Tratamento Térmico da Membrana $\left(144 \mathrm{~cm}^{2}\right) \ldots . .83$

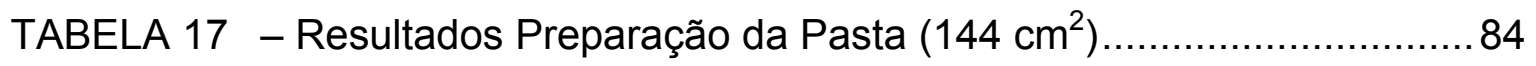

TABELA 18 - Resultados Massas dos Potes $\left(144 \mathrm{~cm}^{2}\right)$................................... 86

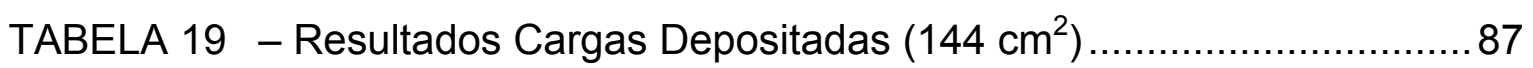

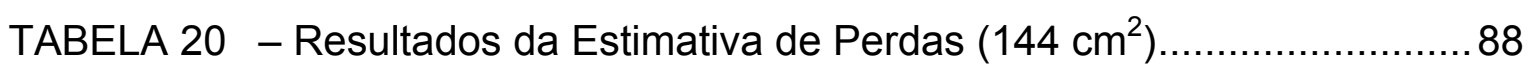

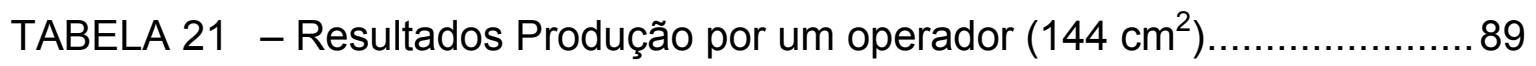

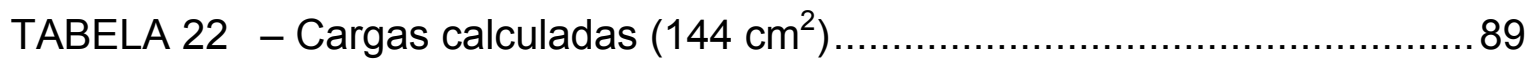

TABELA 23 - Resultados no Potencial de Operação $\left(144 \mathrm{~cm}^{2}\right)$....................... 90

TABELA 24 - Resultados na Potência Máxima $\left(144 \mathrm{~cm}^{2}\right)$................................ 94

TABELA 25 - Custo dos Materiais da Célula Unitária.....................................97

TABELA 26 - Custo dos Serviços realizados na Célula Unitária ......................97

TABELA 27 - Estimativa de custo (Spr - Aspersão; Sie - Impressão à Tela) ... 98

TABELA 28 - Cálculo da massa total de pasta produzida ...............................98

TABELA 29 - Cálculo dos componentes sólidos .........................................99

TABELA 30 - Componentes da pasta catalítica de referência ......................... 99

TABELA 31 - Quadro de massas por lote .......................................... 100

TABELA 32 - Custo da pasta catalítica por MEA .................................... 100

TABELA 33 - Custo total dos componentes por MEA ............................... 101 
TABELA 34 - Simulação de Custo (Ope - operadores; HH - homem-hora).. 102 


\section{LISTA DE FIGURAS}

FIGURA 1 - Esquema de uma PEMFC e suas reações eletródicas.................... 18

FIGURA 2 - Ilustração dos componentes de um MEA .................................... 20

FIGURA 3 - llustração da cadeia polimérica da membrana NAFION ${ }^{\circledR}$................20

FIGURA 4 - Ilustração da estrutura da membrana NAFION ${ }^{\circledR} \ldots \ldots \ldots \ldots \ldots \ldots \ldots \ldots . . . \ldots 21$

FIGURA 5 - Principais fenômenos de transporte dentro da membrana ...............22

FIGURA 6 - Ilustração do EDG. Fonte - /LIT04/ ..........................................23

FIGURA 7 - Processo básico de Impressão à Tela. Fonte - /GWE97/ ............... 26

FIGURA 8 - Perfis de Canais de Gás: (a) PQ20, (b) PQ15 e (c) PT................... 52

FIGURA 9 - Curvas de Polarização dos MEAs $\left(25 \mathrm{~cm}^{2}\right)$ pintados por Impressão à Tela com a tinta 102EA (solução de Nafion $^{\circledR} 10 \%$ em massa, 2EEA e $\mathrm{H}_{2} \mathrm{O}$ ultrapura). Operação com $\mathrm{H}_{2} / \mathrm{O}_{2}$ puros. Umidificação somente no ânodo $\left(85^{\circ} \mathrm{C}\right)$. Vazões com o dobro da estequiometria. Temperatura de célula mantida a $70{ }^{\circ} \mathrm{C}$. 64

FIGURA 10 - Curvas de Polarização dos MEAs $\left(25 \mathrm{~cm}^{2}\right)$ pintados por Impressão à Tela com a tinta 52ES (solução de Nafion ${ }^{\circledR} 5 \%$ em massa e 2EEA). Operação com $\mathrm{H}_{2} / \mathrm{O}_{2}$ puros. Umidificação somente no ânodo (85 $\left.{ }^{\circ} \mathrm{C}\right)$. Vazões com o dobro da estequiometria. Temperatura de célula mantida a $70{ }^{\circ} \mathrm{C}$ 65

FIGURA 11 - Curvas de Polarização dos MEAs $\left(25 \mathrm{~cm}^{2}\right)$ pintados por Impressão à Tela com a tinta 5 SS (solução de Nafion $^{\circledR} 5 \%$ em massa sem 2EEA). Operação com $\mathrm{H}_{2} / \mathrm{O}_{2}$ puros. Umidificação somente no ânodo $\left(85^{\circ} \mathrm{C}\right)$. Vazões com o dobro da estequiometria. Temperatura de célula mantida a $70{ }^{\circ} \mathrm{C}$. 66

FIGURA 12 - Curvas de Polarização dos melhores MEAs $\left(25 \mathrm{~cm}^{2}\right)$ de cada tinta (Sie25_02c, Sie25_04c e Sie25_06a) pintados por Impressão à Tela. Operação com $\mathrm{H}_{2} / \mathrm{O}_{2}$ puros. Umidificação somente no ânodo (85 $\left.{ }^{\circ} \mathrm{C}\right)$. Vazões com o dobro da estequiometria. Temperatura de célula mantida a $70^{\circ} \mathrm{C}$. 67

FIGURA 13 - Curvas de Potência dos melhores MEAs $\left(25 \mathrm{~cm}^{2}\right)$ de cada tinta (Sie25_02c, Sie25_04c e Sie25_06a) pintados por Impressão à Tela. Operação com $\mathrm{H}_{2} / \mathrm{O}_{2}$ puros. Umidificação somente no ânodo (85 ${ }^{\circ} \mathrm{C}$ ). Vazões com o dobro da estequiometria. Temperatura de célula mantida a $70^{\circ} \mathrm{C}$ 
FIGURA 14 - Curva de Polarização e de Potência do melhor MEA $\left(25 \mathrm{~cm}^{2}\right)$ (Sie25_04c) pintado por Impressão à Tela. Operação com $\mathrm{H}_{2} / \mathrm{O}_{2}$ puros. Umidificação somente no ânodo $\left(85^{\circ} \mathrm{C}\right)$. Vazões com o dobro da estequiometria. Temperatura de célula mantida a $70^{\circ} \mathrm{C}$............. 70

FIGURA 15 - MEV da superfície dos MEAs (sem prensagem): (a) Aspersão; (b)

Impressão à Tela ................................................................. 71

FIGURA 16 - MEV da seção transversal dos MEAs (sem prensagem): (a)

Aspersão; (b) Impressão à Tela. ................................................. 72

FIGURA 17 - MEV dos MEAs com GDLs descolados: (a) Aspersão; (b)

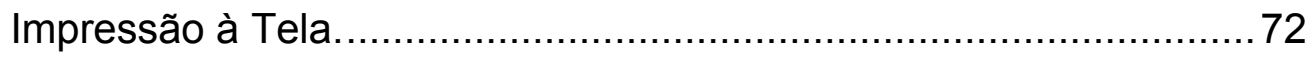

FIGURA 18 - Curvas de Polarização dos melhores MEAs $\left(25 \mathrm{~cm}^{2}\right)$ com e sem tratamento químico posterior à confecção por Aspersão e do melhor MEA produzido por Impressão à Tela. Operação com $\mathrm{H}_{2} / \mathrm{O}_{2}$ puros. Umidificação somente no ânodo $\left(85^{\circ} \mathrm{C}\right)$. Vazões com o dobro da estequiometria. Temperatura de célula mantida a $70^{\circ} \mathrm{C}$. .................. 74

FIGURA 19 - Curvas de Potência dos melhores MEAs $\left(25 \mathrm{~cm}^{2}\right)$ com e sem tratamento químico posterior à confecção por Aspersão e do melhor MEA produzido por Impressão à Tela. Operação com $\mathrm{H}_{2} / \mathrm{O}_{2}$ puros. Umidificação somente no ânodo $\left(85^{\circ} \mathrm{C}\right)$. Vazões com o dobro da estequiometria. Temperatura de célula mantida a $70^{\circ} \mathrm{C}$................... 76

FIGURA 20 - PQ20 - canal quadrado (2 mm), parede quadrada $(2 \mathrm{~mm})$........... 77

FIGURA 21 - PQ15 - canal quadrado (1,5 mm), parede de 0,5 mm x 1,5 mm ...77

FIGURA 22 - PT - canal trapezoidal $(b=1 \mathrm{~mm} ; \mathrm{B}=2 \mathrm{~mm})$, parede triangular ..78

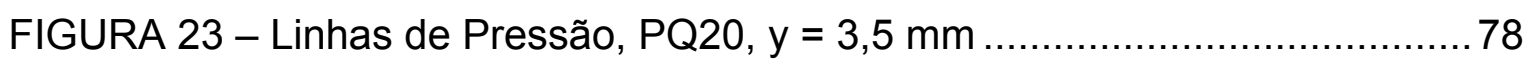

FIGURA 24 - Linhas de Pressão, PQ15, y = 3,5 mm ...................................... 79

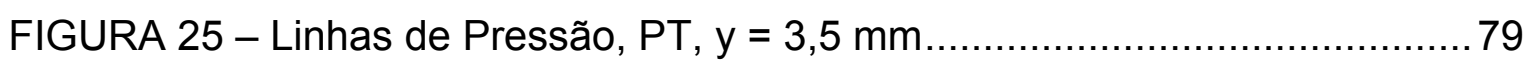

FIGURA 26 - Velocidade (direção z), PQ20, y = 3,5 mm …………................ 80

FIGURA 27 - Velocidade (direção z), PQ15, y = 3,5 mm ................................. 80

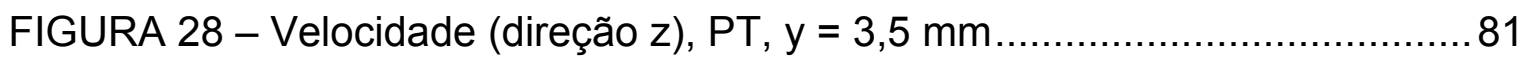

FIGURA 29 - Impressão do experimento de altura de mesa............................... 85

FIGURA 30 - Curvas de Polarização dos MEAs $\left(144 \mathrm{~cm}^{2}\right)$ confeccionados por Aspersão. Operação com $\mathrm{H}_{2} / \mathrm{O}_{2}$ puros. Umidificação no ânodo $\left(90^{\circ} \mathrm{C}\right)$ e no cátodo $\left(80^{\circ} \mathrm{C}\right)$. Vazões de $1,0 \mathrm{~L} \cdot \mathrm{min}^{-1}$. Temperatura de célula

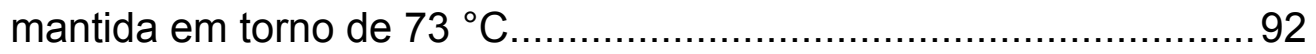


FIGURA 31 - Curvas de Polarização dos MEAs $\left(144 \mathrm{~cm}^{2}\right)$ confeccionados por Impressão à Tela. Operação com $\mathrm{H}_{2} / \mathrm{O}_{2}$ puros. Umidificação no ânodo $\left(90^{\circ} \mathrm{C}\right)$ e no cátodo $\left(80^{\circ} \mathrm{C}\right)$. Vazões de $1,0 \mathrm{~L} \cdot \mathrm{min}^{-1}$. Temperatura de célula mantida em torno de $65^{\circ} \mathrm{C}$ 91

FIGURA 32 - Curvas de Polarização dos melhores MEAs $\left(144 \mathrm{~cm}^{2}\right)$, Aspersão, Impressão à Tela e o comercial da E-TEK. Operação com $\mathrm{H}_{2} / \mathrm{O}_{2}$ puros. Umidificação no ânodo $\left(90^{\circ} \mathrm{C}\right)$ e no cátodo $\left(80^{\circ} \mathrm{C}\right)$. Vazões de 1,0 L. $\mathrm{min}^{-1}$. Temperatura de célula mantida entre $65^{\circ} \mathrm{C}$ e $73^{\circ} \mathrm{C} \ldots . . .93$

FIGURA 33 - Curvas de Potência dos melhores MEAs $\left(144 \mathrm{~cm}^{2}\right)$, Aspersão, Impressão à Tela e o comercial da E-TEK. Operação com $\mathrm{H}_{2} / \mathrm{O}_{2}$ puros. Umidificação no ânodo $\left(90^{\circ} \mathrm{C}\right)$ e no cátodo $\left(80^{\circ} \mathrm{C}\right)$. Vazões de 1,0 L.min ${ }^{-1}$. Temperatura de célula mantida entre $65^{\circ} \mathrm{C}$ e $73^{\circ} \mathrm{C} \ldots . . .95$ 


\section{LISTA DE ABREVIATURAS E SIGLAS}

AFC Alkaline Fuel Cell

CaC Célula a Combustível

CAD Computer Aided Engineer

CCTM Centro de Ciência e Tecnologia dos Materiais do IPEN

DAFC Direct Alcohol Fuel Cell

DMFC Direct Methanol Fuel Cell

EDG Eletrodo de Difusão Gasosa

FDC Fluido Dinâmica Computacional

GDL Gas Diffusion Layer

HIAT Hydrogen Institute for Applied Technology

IPEN Instituto de Pesquisas Energéticas e Nucleares

MCFC Molten Carbonate Fuel Cell

MEA Membrane Electrode Assembly

MEV Microscopia Eletrônica de Varredura

PAFC Phosphoric Acid Fuel Cell

PEMFC Proton Exchange Membrane Fuel Cell

$\mathrm{PROH} 2$ Programa Brasileiro de Célula a Combustível e Hidrogênio

PTFE Politetrafluoretileno

RRO Reação de Redução do Oxigênio

SOFC Solid Oxide Fuel Cell

USP Universidade de São Paulo

vol\% Percentual em volume de um componente

WML Water Management Layer

2EEA 2-[2 Ethoxyethoxy] Ethyl Acetate 


\section{LISTA DE SÍMBOLOS}

$\rightarrow \quad$ Indica direção preferencial da reação química

$E_{e q} \quad$ Potencial de Equilíbrio da Reação

$E_{e q}^{o} \quad$ Potencial Padrão de Equilíbrio - ocorre com substâncias em solução de concentração unitária $\left(1,0 \mathrm{~mol} \cdot \mathrm{L}^{-1}\right)$. Para gases, ocorre à pressão de uma atmosfera. Ocorre a $25^{\circ} \mathrm{C}(298 \mathrm{~K})$.

$R \quad$ Constante Universal dos Gases $\left(R=8,314 \mathrm{~J} \cdot \mathrm{mol}^{-1} \cdot \mathrm{K}^{-1}\right)$

T Temperatura

z $\quad$ Número de elétrons envolvidos na reação

F $\quad$ Constante de Faraday $\left(F \approx 96500 C . \mathrm{mol}^{-1}\right)$

ln Logaritmo neperiano

П Produtório

$E_{\text {célula }} \quad$ Potencial da Célula $\left(E_{\text {célula }}=\mathbf{E}\right)$

$\eta_{\text {ânodo }} \quad$ Somatório das Polarizações no Ânodo

$\eta_{\text {cátodo }}$ Somatório das Polarizações no Cátodo

$\eta^{R} \quad$ Polarização por Queda Ôhmica

$\eta_{\text {ânodo }}^{A} \quad$ Polarização por Ativação no Ânodo

$\eta_{\text {ânodo }}^{C} \quad$ Polarização por Concentração no Ânodo

$\eta_{\text {cátodo }}^{A} \quad$ Polarização por Ativação no Cátodo

$\eta_{\text {cátodo }}^{C} \quad$ Polarização por Concentração no Cátodo

$\mu \quad$ Representa $10^{-6}$ da unidade de medida

pKa logaritmo negativo de base 10 da constante de equilíbrio, $K$, da reação entre o composto e a água

$\beta \quad$ Parâmetro de basicidade

$\Omega \quad$ Ohm (unidade de resistência elétrica) 


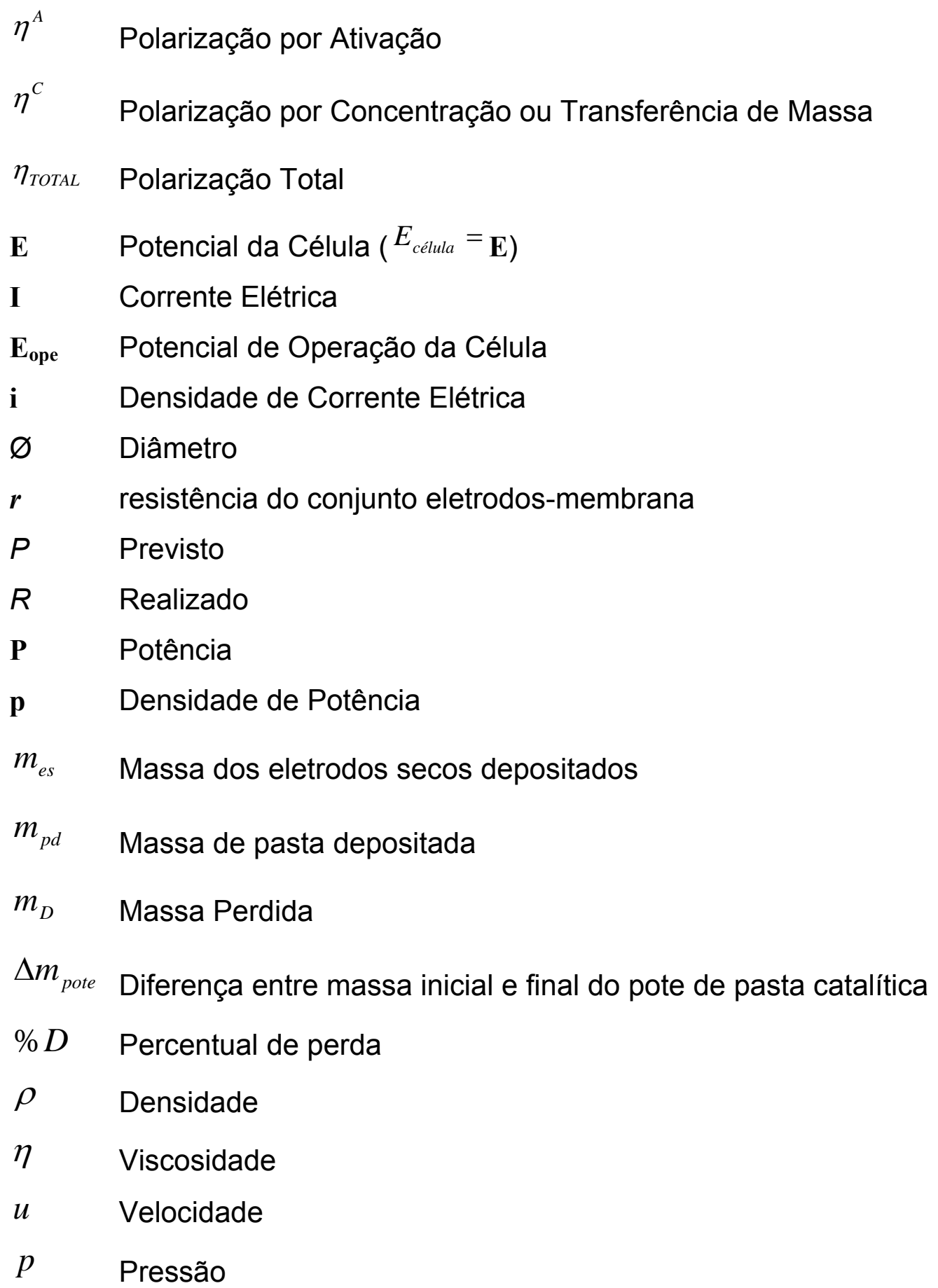




\section{INTRODUÇÃO}

A Célula a Combustível $(\mathrm{CaC})$ é um dispositivo de conversão direta de energia química em energia elétrica e térmica, possuindo uma operação contínua em função da alimentação constante de reagentes. Existem vários tipos de CaCs, na TAB.1 são apresentados os principais, classificados segundo o tipo de eletrólito que utilizam e, conseqüentemente, segundo a temperatura de operação.

TABELA 1 - Principais tipos de Célula a Combustível

\begin{tabular}{|c|c|c|}
\hline $\begin{array}{c}\text { TIPO } \\
\text { (abreviação em inglês) }\end{array}$ & $\begin{array}{l}\text { ELETRÓLITO } \\
\text { (íon transportado) }\end{array}$ & $\begin{array}{c}\text { TEMPERATURA } \\
\left({ }^{\circ} \mathrm{C}\right)\end{array}$ \\
\hline $\begin{array}{l}\text { Alcalina } \\
\text { (AFC) }\end{array}$ & $\begin{array}{l}\mathrm{KOH} \\
\left(\mathrm{OH}^{-}\right)\end{array}$ & $60 \sim 90$ \\
\hline $\begin{array}{l}\text { Membrana Polimérica } \\
\text { (PEMFC) (DAFC) }\end{array}$ & $\begin{array}{c}\text { Polímero: Nafion } \\
\left(\mathrm{H}_{3} \mathrm{O}^{+}\right)\end{array}$ & $60 \sim 90$ \\
\hline $\begin{array}{l}\text { Ácido Fosfórico } \\
\text { (PAFC) }\end{array}$ & $\begin{array}{c}\mathrm{H}_{3} \mathrm{PO}_{3}-\text { Matriz de SiC } \\
\left(\mathrm{H}_{3} \mathrm{O}^{+}\right)\end{array}$ & $160 \sim 200$ \\
\hline $\begin{array}{c}\text { Carbonatos Fundidos } \\
\text { (MCFC) }\end{array}$ & $\begin{array}{c}\text { Carbonatos Fundidos - } \\
\text { Matriz de } \mathrm{LiAlO}_{2} \\
\left(\mathrm{CO}_{3}{ }^{2-}\right)\end{array}$ & $650 \sim 700$ \\
\hline $\begin{array}{l}\text { Cerâmicas } \\
\text { (SOFC) }\end{array}$ & $\begin{array}{l}\mathrm{ZrO}_{2} \\
\left(\mathrm{O}^{2-}\right)\end{array}$ & $800 \sim 1000$ \\
\hline
\end{tabular}

Fonte - /BAL03/.

Os vários tipos de $\mathrm{CaCs}$ existentes envolvem materiais constituintes distintos e, portanto, técnicas de construção diversas, implicando em tecnologias diferentes de fabricação.

O tipo de $\mathrm{CaC}$ estudada neste trabalho é a Célula a Combustível com Membrana Polimérica Trocadora de Prótons (PEMFC - abreviação do inglês Proton Exchange Membrane Fuel Cell) e na FIG.1 mostra-se o esquema de uma célula deste tipo.

Dentro da PEMFC, a variação do processo de fabricação do conjunto eletrodos-membrana (MEA - abreviação do inglês Membrane Electrodes Assembly) afeta diretamente as características do conjunto e conseqüentemente o desempenho da célula. O processo de fabricação do MEA é o alvo principal deste trabalho. Assim, para um melhor entendimento, é preciso primeiro uma 
introdução sobre os componentes e as características do MEA e sobre os processos fenomenológicos que ocorrem na PEMFC.

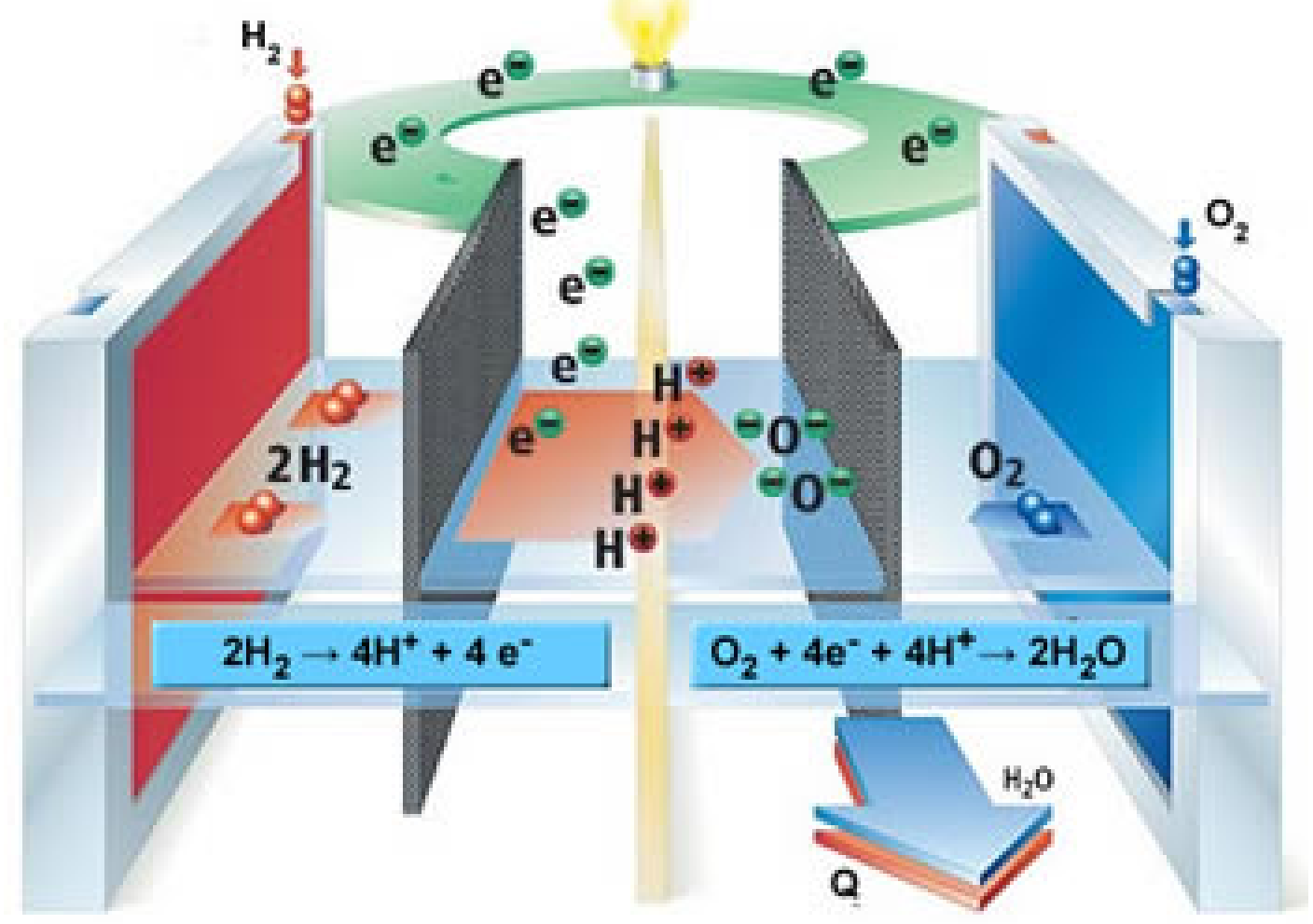

FIGURA 1 - Esquema de uma PEMFC e suas reações eletródicas

A conversão direta de energia química em energia elétrica e térmica ocorre por meio de duas reações eletroquímicas parciais em dois eletrodos, separados por um eletrólito. A oxidação do combustível ocorre no ânodo e a redução do oxidante no cátodo. Operando a PEMFC com hidrogênio (combustível) e oxigênio (oxidante) os seguintes mecanismos são possíveis:

- Reação no Ânodo (oxidação do hidrogênio):

$$
\begin{array}{ll}
\text { Adsorção: } & \mathrm{H}_{2} \rightarrow \mathrm{H}_{2, \text { ads }} \\
\text { Tafel: } & \mathrm{H}_{2, \text { ads }} \rightarrow 2 \mathrm{H}_{\text {ads }} \\
\text { Heyrovsky: } & \mathrm{H}_{2, \text { ads }}+\mathrm{H}_{2} \mathrm{O} \rightarrow \mathrm{H}_{\text {ads }}+\mathrm{H}_{3} \mathrm{O}^{+}+\mathrm{e}^{-} \\
\text {Volmer: } & 2 \mathrm{H}_{\text {ads }}+2 \mathrm{H}_{2} \mathrm{O} \rightarrow 2 \mathrm{H}_{3} \mathrm{O}^{+}+2 \mathrm{e}^{-}
\end{array}
$$

Segundo Ticianelli e Gonzales /TIC05/, o caminho da reação depende do material do eletrodo, considerando a oxidação do hidrogênio em meio ácido, duas diferentes seqüências podem ocorrer: o mecanismo de Tafel-Volmer ou o mecanismo de Heyrovsky-Volmer. Ao utilizar a platina metálica, a reação (2) é 
bastante favorecida e a oxidação do hidrogênio ocorre praticamente só pelo mecanismo de Tafel-Vomer.

- Reação no Cátodo (redução do oxigênio):

Adsorção: $\quad \mathrm{O}_{2} \rightarrow \mathrm{O}_{2, \text { ads }}$

Mecanismo Direto:

$$
\mathrm{O}_{2, \text { ads }}+4 \mathrm{H}_{3} \mathrm{O}^{+}+4 \mathrm{e}^{-} \rightarrow 6 \mathrm{H}_{2} \mathrm{O}
$$

Mecanismo Indireto:

$$
\begin{aligned}
& \mathrm{O}_{2, \text { ads }}+\mathrm{H}_{3} \mathrm{O}^{+}+\mathrm{e}^{-} \rightarrow \mathrm{O}_{2} \mathrm{H}_{\mathrm{ads}}+\mathrm{H}_{2} \mathrm{O} \\
& \mathrm{O}_{2} \mathrm{H}_{\mathrm{ads}}+\mathrm{H}_{3} \mathrm{O}^{+}+\mathrm{e}^{-} \rightarrow \mathrm{H}_{2} \mathrm{O}_{2}+\mathrm{H}_{2} \mathrm{O} \\
& \mathrm{H}_{2} \mathrm{O}_{2}+2 \mathrm{H}_{3} \mathrm{O}^{+}+2 \mathrm{e}^{-} \rightarrow 4 \mathrm{H}_{2} \mathrm{O}
\end{aligned}
$$

Ao utilizar a platina metálica, o mecanismo direto (6) é privilegiado. A seguir são representadas as duas reações químicas parciais e a global.

Ânodo: $\quad 2 \mathrm{H}_{2}+4 \mathrm{H}_{2} \mathrm{O} \rightarrow 4 \mathrm{H}_{3} \mathrm{O}^{+}+4 \mathrm{e}^{-}$

Cátodo: $\quad \mathrm{O}_{2}+4 \mathrm{H}_{3} \mathrm{O}^{+}+4 \mathrm{e}^{-} \rightarrow 6 \mathrm{H}_{2} \mathrm{O}$

Global: $\quad 2 \mathrm{H}_{2}+\mathrm{O}_{2}+4 \mathrm{H}_{2} \mathrm{O} \rightarrow 6 \mathrm{H}_{2} \mathrm{O}$

As reações foram assim colocadas para que sejam ilustrados o consumo de água no ânodo e a formação de água no cátodo. O potencial de equilíbrio da célula é calculado pela equação de Nernst:

$$
E_{e q}=E_{e q}^{o}-\frac{R T}{z F} \ln \left(\frac{\prod a_{i}^{v_{i}} \text { produtos }}{\prod a_{i}^{v_{i}} \text { reagentes }}\right)
$$

Considerando a reação $\mathrm{H}_{2}(\mathrm{~g})+{ }^{1} / \mathrm{O}_{2}(\mathrm{~g}) \leftrightarrow \mathrm{H}_{2} \mathrm{O}(\mathrm{g})$, temos:

$$
\begin{aligned}
& E_{\text {eq }}=E_{\text {eq }}^{o}-\frac{R T}{z F} \ln \left(\frac{p\left(\mathrm{H}_{2} \mathrm{O}\right)_{\text {cátodo }}^{1}}{p\left(\mathrm{H}_{2}\right)^{1} \cdot p\left(\mathrm{O}_{2}\right)^{1 / 2}}\right) \\
& \text { onde } E_{\text {eq }}^{o}=1,23 V \quad \text { e } \quad E_{\text {célula }}=E_{\text {eq }}-\eta_{\text {ânodo }}-\left|\eta_{\text {cátodo }}\right|-\eta^{R} \\
& \text { com, } \eta_{\text {cátodo }}=\eta_{\text {cátodo }}^{A}+\eta_{\text {cátodo }}^{C} \\
& \text { e } \eta_{\text {ânodo }}=\eta_{\text {ânodo }}^{A}+\eta_{\text {ânodo }}^{C} .
\end{aligned}
$$


Todas as reações ocorrem no MEA, assim seus componentes (FIG.2) são peças importantes para o desempenho da célula a combustível.

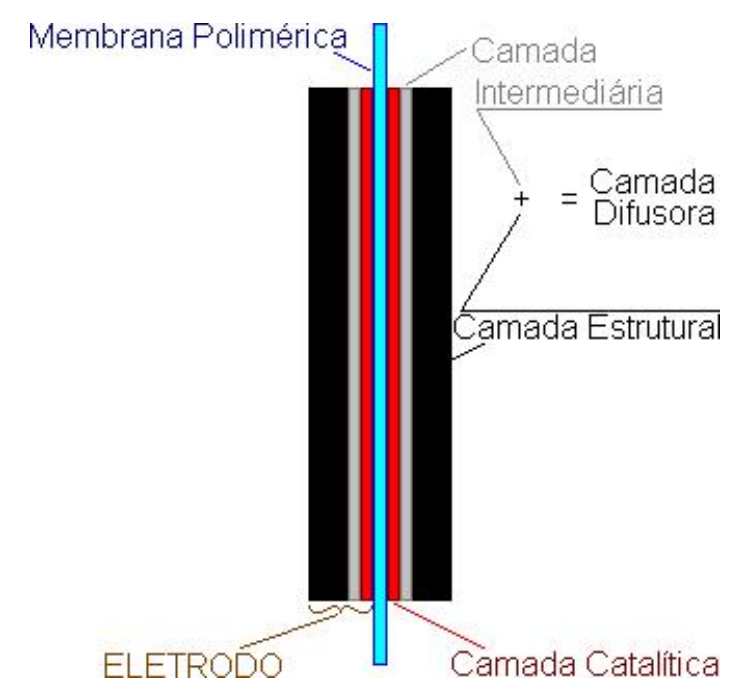

FIGURA 2 - llustração dos componentes de um MEA

O eletrólito da PEMFC (em azul na FIG.2) é uma membrana sólida que deve ser mantida hidratada para que ocorra a troca de prótons $\left(\mathrm{H}^{+}\right)$do ânodo para o cátodo. Este transporte protônico não ocorre de maneira isolada na membrana polimérica, outros fenômenos acoplados a este mecanismo estão acontecendo para que efetivamente seja possível a chegada da espécie carregada positivamente no lado catódico. O estado da arte nesse tipo de célula é o uso da membrana NAFION ${ }^{\circledR}$. Tal membrana é formada basicamente por um esqueleto de TEFLON $^{\circledR}$ com grupos sulfônicos ligados à cadeias laterais. Nas FIG.3 e 4 são apresentadas ilustrações desta estrutura. O TEFLON ${ }^{\circledR}$ possui propriedades hidrofóbicas e boa estabilidade a atmosferas oxidante e redutora na temperatura de operação da célula $\left(60^{\circ} \mathrm{C}\right.$ a $\left.80^{\circ} \mathrm{C}\right)$.

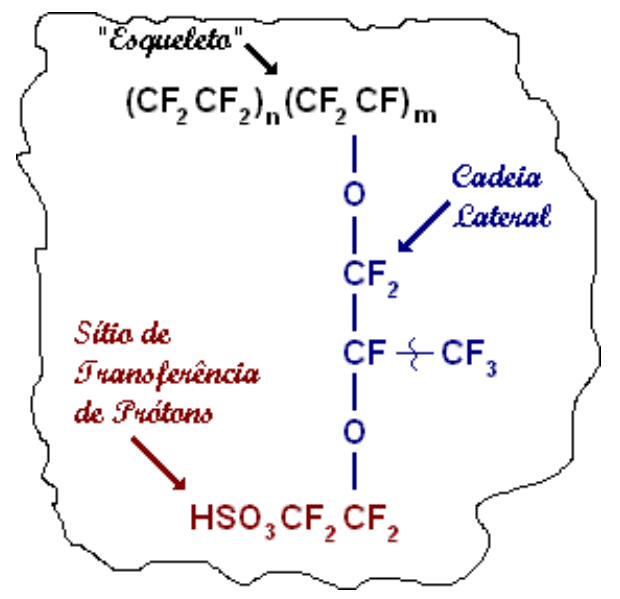

FIGURA 3 - llustração da cadeia polimérica da membrana NAFION ${ }^{\circledR}$ 
Os grupos sulfônicos $\left(\mathrm{SO}_{3}{ }^{-}\right)$são hidrofílicos e é por esta característica que o transporte de prótons é possível.

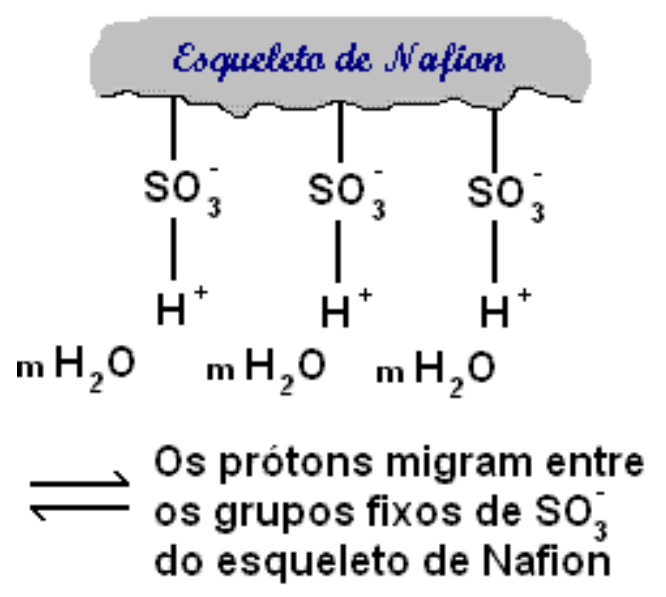

FIGURA 4 - llustração da estrutura da membrana NAFION ${ }^{\circledR}$

Com o aumento da temperatura de operação a membrana pode começar a ressecar, restringindo o transporte de prótons e aumentando sua resistividade. A manutenção desta situação indesejável ou o contínuo aumento da temperatura pode levar ao aparecimento de danos irreversíveis na membrana. Desta maneira, a hidratação da membrana durante toda a operação é condição sine qua non para o bom desempenho da célula. $\mathrm{O}$ aumento da pressão de trabalho dos gases reagentes na célula favorece a operação em temperaturas mais elevadas sem o ressecamento da membrana, porém a temperatura limite ainda mantém a classificação da PEMFC como célula de baixa temperatura de operação.

O fenômeno de transporte iônico é associado aos mecanismos de arraste eletro-osmótico, difusão da água e transferência por gradiente de pressão /DEF04/. Sendo que este último pode ser imposto ou não em função dos parâmetros de operação. Os processos de umidificação dos gases reagentes e de evaporação podem contribuir adversa ou positivamente na condutividade da membrana. O processo de evaporação apresenta uma provável menor contribuição /FRE01/.

O transporte eletro-osmótico (FIG.5) ocorre devido ao arraste da água pela hidratação do próton que é transferido do ânodo para o cátodo. Os prótons $\left(\mathrm{H}^{+}\right)$não são estáveis e precisam se associar a uma ou mais moléculas de água formando espécies $\mathrm{H}_{3} \mathrm{O}^{+}$que são arrastadas para o lado catódico em função de uma diferença de potencial (campo elétrico). $\mathrm{O}$ deslocamento só se torna possível 
pela existência de um caminho preferencial formado pelos grupos sulfônicos da estrutura da membrana.

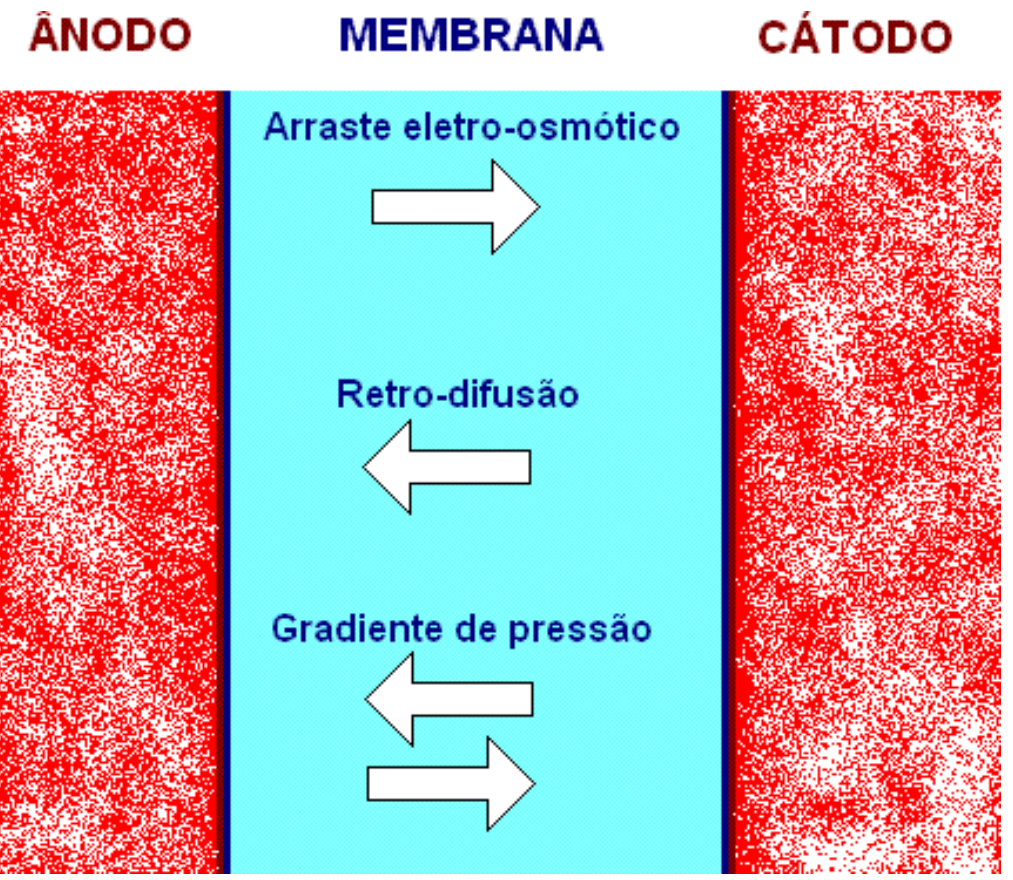

FIGURA 5 - Principais fenômenos de transporte dentro da membrana

A difusão da água (também chamada de retro-difusão) é aquela que move as moléculas de água do lado do cátodo, onde a água é produzida na reação de redução do oxigênio (RRO), para o lado anódico. Isto ocorre devido ao gradiente de concentração de água existente entre os dois lados. Lado catódico é mais saturado em relação ao lado do ânodo. Caso não houvesse alimentação de água no lado anódico e o processo de retro-difusão fosse impedido, haveria um ressecamento natural da membrana promovendo o impedimento do transporte protônico, uma vez que o $\mathrm{H}^{+}$depende da $\mathrm{H}_{2} \mathrm{O}$ para chegar ao outro lado (cátodo).

Confrontando os dois mecanismos (arraste eletro-osmótico e retrodifusão), percebe-se que o próton do hidrogênio está envolvido num mecanismo de contra fluxo, com $\mathrm{H}_{3} \mathrm{O}^{+}$se deslocando do ânodo para o cátodo $\mathrm{e}_{2} \mathrm{O}$ movendo-se em sentido contrário.

O fluxo de água que surge por efeito de um gradiente de pressão pode ser especialmente importante no gerenciamento de água da célula a combustível de membrana polimérica, porque auxilia na condução da água em um sentido que favoreça a hidratação da membrana sem que haja concentração demasiada de água em um eletrodo. Esta concentração poderia ser tal que acarretaria o 
alagamento deste componente obstruindo a chegada de reagentes nos sítios ativos e diminuindo o desempenho da PEMFC. Por outro lado, considerando os três mecanismos retratados até agora, o efeito da convecção é geralmente negligenciado quando comparado com os efeitos de arraste eletro-osmótico e retro-difusão, isto devido à baixa permeabilidade hidráulica existente na membrana /YAN05/.

De cada lado da membrana está disposto um eletrodo de difusão gasosa (EDG). O eletrodo de difusão gasosa é uma estrutura porosa condutora de elétrons do sistema eletrodo/eletrocatalisador, utilizado em células a combustível de baixa temperatura de operação /WEN00/. No EDG estão presentes três fases distintas, denominadas de tripla fase reacional. A gasosa é formada pelos gases reagentes, a sólida é o sistema eletrodo/eletrocatalisador e a líquida é atribuída ao eletrólito, que embora seja sólido só opera se estiver úmido /BAL03/.

O EDG contém geralmente duas camadas porosas. Na FIG.6 ilustra-se o EDG e suas camadas.

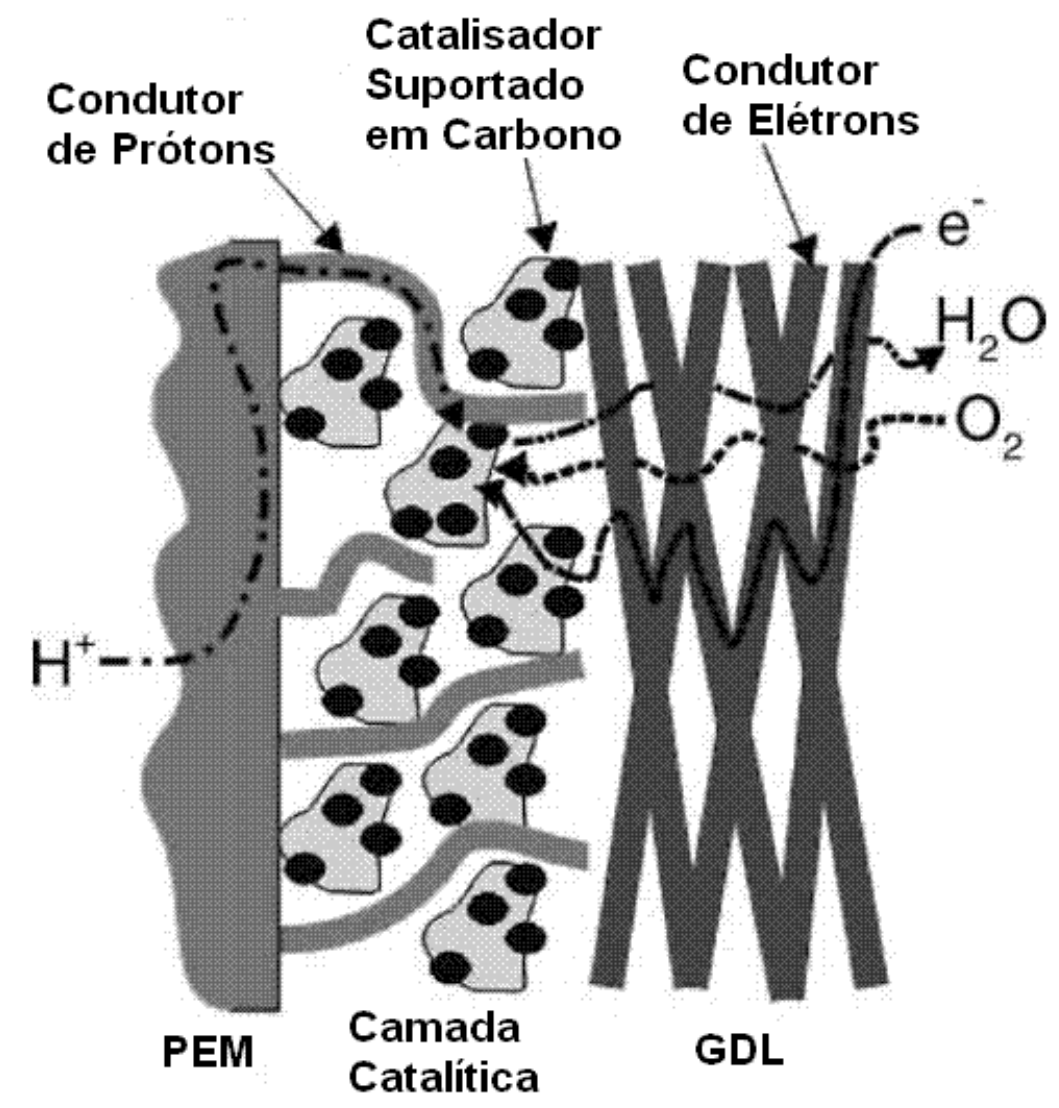

FIGURA 6 - Ilustração do EDG. Fonte - /LIT04/ 
- Camada difusora (GDL - abreviação do inglês Gas Diffusion Layer)

Com características hidrofóbicas se situa mais perto dos canais de gás. Distribui o gás reagente, remove os produtos e conecta eletricamente a camada catalítica ao circuito externo. Também atua como suporte mecânico do eletrodo.

- Camada catalítica

Fica em contato direto com a membrana. A camada catalítica é hidrofílica. Tem a função de promover eficientemente a reação eletroquímica.

O EDG tem como objetivo fornecer uma grande área reacional (maximizar a tripla fase reacional) com o mínimo de resistência e facilitar o acesso de reagentes (combustível e oxidante) e a retirada de produtos (água e gases excedentes). Na prática, o EDG deve satisfazer dois requisitos operacionais:

1. Deve ser altamente eletroativo para que a PEMFC alcance a maior densidade de corrente possível para um mesmo potencial de trabalho (por exemplo, valores acima de $600 \mathrm{~mA} . \mathrm{cm}^{-2}$ a $600 \mathrm{mV}$ );

2. Durante a operação, os poros não devem ser totalmente inundados (o que impediria a passagem dos gases reagentes) e nem devem estar completamente secos (assim, a tripla fase reacional não seria maximizada).

Os fenômenos de transporte que ocorrem na membrana, somados àqueles presentes no eletrodo definem o compromisso da estrutura do MEA com o desempenho da PEMFC. A aplicação (estacionária, portátil ou veicular) e as condições de operação, os materiais constituintes e o processo de fabricação são os principais parâmetros que influenciam os fenômenos de transporte que governam o desempenho da célula.

A definição da aplicação restringe as opções existentes para as condições de operação. Quanto a estas, o potencial (em torno de $600 \mathrm{mV}$ ) e a temperatura (entre $60^{\circ} \mathrm{C}$ e $90^{\circ} \mathrm{C}$ ) de operação, bem como a umidificação dos gases de entrada são decisões que se bem utilizadas promoverão altas densidades de corrente.

Cabe uma ressalva, embora alguns trabalhos (/ECK04/; MIL04/ e /YOS05/) sejam realizados de maneira a estudar o comportamento da célula a combustível do tipo PEMFC, operando com baixa ou nenhuma umidificação, os melhores resultados de desempenho, tanto em células unitárias como em pilhas a combustível, são obtidos com a umidificação dos gases reagentes. A umidificação 
do combustível na entrada do ânodo tem sido usada para evitar o ressecamento neste lado da célula, uma vez que o próton $\mathrm{H}^{+}$formado na reação de oxidação do hidrogênio precisa de água para se associar e migrar pela membrana. A umidificação do oxidante também é muito utilizada e defendida como ferramenta para ajudar a minimizar o efeito de secagem da membrana. Existem estágios de umidificação que podem ser utilizados no empilhamento (módulo ou pilha) de células do tipo PEMFC. De qualquer forma, seja em módulos ou em células unitárias, seja no cátodo, no ânodo ou nos dois lados da membrana, a umidificação deve ser otimizada para as condições de operação e configurações dos eletrodos. Se isto não for observado um possível mau desempenho do conjunto poderá ser notado em conseqüência do excesso de água nos eletrodos (encharcamento).

O estado da arte em relação aos materiais empregados no MEA das PEMFC é o uso da membrana NAFION ${ }^{\circledR}$ como eletrólito e platina nanoestruturada em carbono como eletrocatalisador. Além disso, o uso do ionômero da membrana na composição do eletrodo figura entre as descobertas mais importantes. Porém, mesmo empregando os melhores materiais, um bom desempenho da PEMFC só será obtido se tais materiais puderem ser dispostos de maneira a maximizar seu uso e suas potencialidades durante a operação da célula. Os métodos de fabricação do MEA influenciam diretamente sobre a maximização do uso dos materiais empregados além conferir características ao produto final que podem direcionar a aplicação da PEMFC e as condições a serem utilizadas durante a operação.

Neste cenário, um ponto chave aparece como primordial para o alcance de um alto desempenho na operação de células e pilhas do tipo PEMFC, o processo de fabricação do MEA. No IPEN, foi solicitada patente e já se encontra bem desenvolvido o processo híbrido de Aspersão/Prensagem a quente.

Porém, este processo apresentou dificuldades para a realização de estudos de aumento de escala, isto é, para a confecção de eletrodos com dimensões maiores. Como havia no laboratório o objetivo de desenvolver módulos de potência de até $1 \mathrm{~kW}$ que utilizam eletrodos de $144 \mathrm{~cm}^{2}$, era necessário desenvolver um método que obtivesse não só eletrodos maiores como também uma boa reprodutibilidade com maior volume de produção. 
Foi escolhido o método de Impressão à Tela, até o momento inédito no país para aplicação em células a combustível. Este método consiste em utilizar um rodo para forçar a passagem de uma tinta por uma peneira (tela) com o intuito de depositá-la em um substrato. Vários fatores influenciam a qualidade da deposição, de características de utensílios a parâmetros do processo passando pela interferência do operador. Um processo mecanizado diminui consideravelmente a interferência do operador e possibilita o aumento do lote de produção. Na FIG.7 é apresentado um processo básico de Impressão á Tela, bem como seus principais componentes.

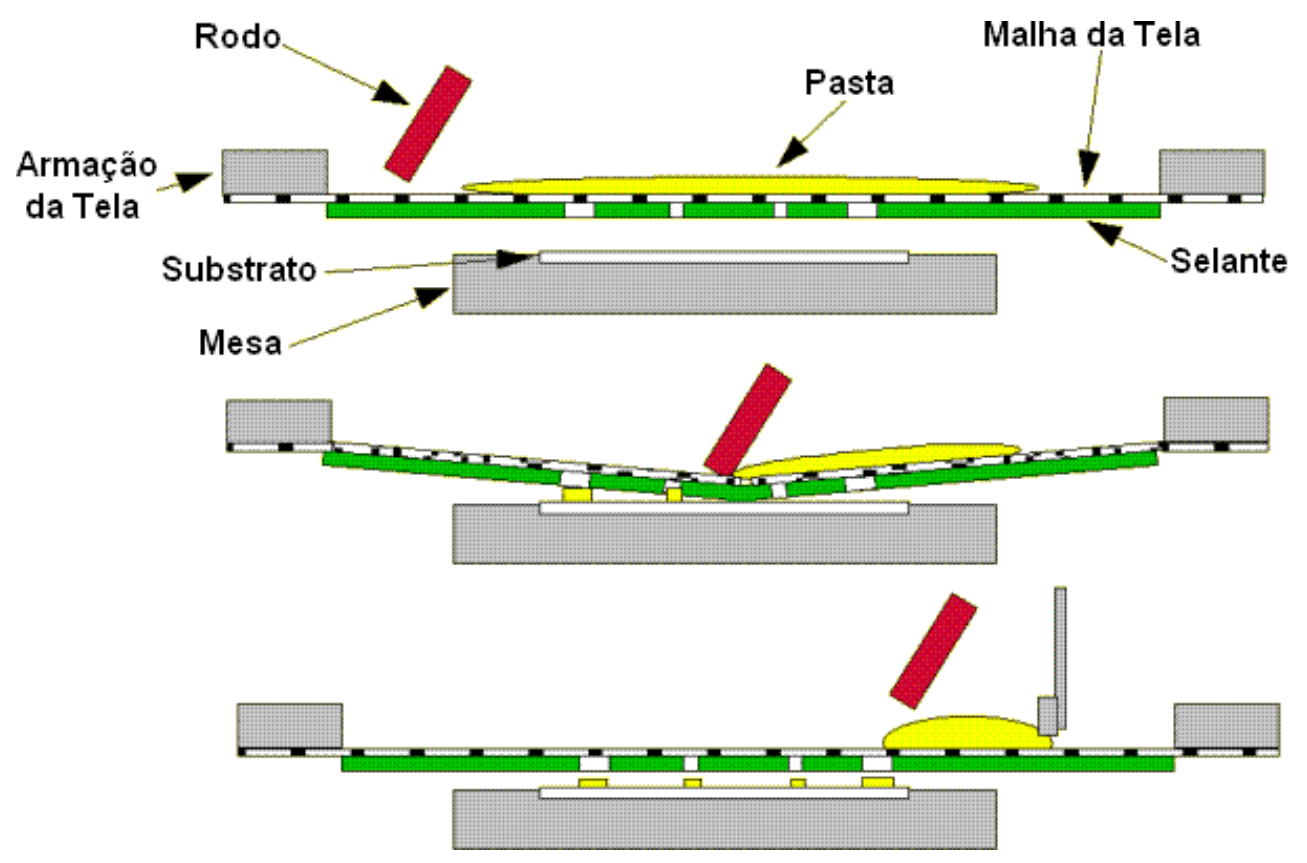

FIGURA 7 - Processo básico de Impressão à Tela. Fonte - /GWE97/

O retângulo vermelho representa o rodo de pintura, a área amarela, a pasta catalítica e o substrato é o retângulo branco de bordas pretas. A pasta catalítica está sobre uma peneira (tela) que é formada pela armação e pela malha. A armação serve para tencionar a malha. A malha é preenchida por uma substância seladora impermeável à tinta exceto na geometria correspondente à forma que se pretende imprimir no substrato.

Quanto às características dos utensílios, as mais importantes são: tela (material, mesh, espessura da malha e o diâmetro do filamento); rodo de impressão e rodo de espalhamento (tipo de material). Em relação aos parâmetros de operação, temos: rodo de impressão (inclinação, pressão e velocidade); rodo de espalhamento (inclinação e velocidade); e distância entre o substrato e a peneira (tal distância é conhecida como Snap Off). 
Todos os fatores listados no parágrafo anterior influenciam na espessura da camada depositada, no preenchimento das áreas pintadas e na definição do contorno da geometria, isto é, eles têm impacto direto sobre a qualidade da impressão e conseqüentemente sobre o desempenho do eletrodo.

Em um processo manual, o operador tem um maior nível de interferência e com isso pode imprimir pressões e velocidades não constantes e assim obter impressões não homogêneas.

Em um processo mecanizado (APÊNDICE A) estas situações indesejadas são evitadas, além disso, outras facilidades podem ser incorporadas ao processo para se obter maior reprodutibilidade de resultados. Por exemplo, um sistema ótico (APÊNDICE A) capaz de auxiliar o operador no posicionamento do substrato é especialmente importante quando a deposição é realizada sobre a membrana. Neste caso, os eletrodos são impressos em lados opostos da mesma membrana e para um bom funcionamento do MEA eles precisam estar alinhados entre si. Um sistema de posicionamento ótico confere maior precisão ao processo de alinhamento e conseqüentemente atribui ao processo de fabricação maior reprodutibilidade na produção de MEAs de bom desempenho.

Mesmo assim, com tantos parâmetros envolvidos, o estudo deste processo de fabricação de MEAs e o desempenho da PEMFC deve ainda levar em consideração a variação das características relacionadas com aplicação, condições de operação e materiais empregados. Isto é, para o desenvolvimento do processo de Impressão à Tela, vários parâmetros devem ser mantidos fixos para facilitar a comparação com outros métodos e para avaliar a reposta em desempenho do MEA produzido quando algum parâmetro significativo do processo é modificado. 


\section{OBJETIVOS}

O objetivo principal deste trabalho consiste no desenvolvimento de um método inovador no Brasil para a fabricação de eletrodos de difusão gasosa (camada catalítica), contendo partículas nanoestruturadas do eletrocatalisador, com uma carga de platina nos eletrodos da ordem de $0,4 \mathrm{mg} \cdot \mathrm{cm}^{-2}$, e de MEAs (adição da camada difusora), utilizando a técnica de Impressão à Tela ("Sieve Printing"), para aplicação em células a combustível do tipo membrana condutora protônica (PEMFC), a custo satisfatório para comercialização.

Quantitativamente, objetiva-se obter densidades de corrente da ordem de, ou superiores a, $400 \mathrm{~mA} \cdot \mathrm{cm}^{-2}$ a $600 \mathrm{mV}$, em células de $25 \mathrm{~cm}^{2}$ para operação com $\mathrm{H}_{2} / \mathrm{O}_{2}$. Além de bom desempenho, espera-se também obter estabilidade química, morfológica e mecânica, além de ótima reprodutibilidade com facilidade de obtenção de MEAs de diversos tamanhos e de mesmas características.

Especificamente, objetiva-se estudar a preparação de diferentes eletrodos e MEA's, com diferentes parâmetros do processo, otimizando-o, incluindo estudos iniciais de aumento de escala de eletrodos de até $144 \mathrm{~cm}^{2}$ de área ativa.

Resumindo, os resultados esperados com a implementação deste novo processo são altas densidades de corrente a $600 \mathrm{mV}$, maior reprodutibilidade, flexibilidade de operação e vantagens de custo inerentes ao processo. 


\section{REVISÃO DA LITERATURA}

Segundo os objetivos deste trabalho, foi realizado um estudo de patentes e publicações relacionadas com o desenvolvimento de MEAs para PEMFC, tendo como focos principais os materiais empregados, os métodos construtivos e a configuração. Os trabalhos considerados foram aqui resumidos. Primeiramente, são apresentadas algumas patentes selecionadas devido à importância das inovações introduzidas e, posteriormente, as publicações relevantes da área.

$\mathrm{Na}$ patente, US 4.876.115 - Electrode assembly for use in a solid polymer electrolyte fuel cell, /UNI89/ - Raistrick apresenta soluções para aplicação de eletrodos de difusão gasosa em conjuntos de eletrodos com eletrólito sólido (conceito do MEA), além de melhorias na estrutura porosa do eletrodo e um método para sua fabricação. As células a combustível mais comuns à época usavam eletrólito líquido para maximizar o contato entre o catalisador e o gás e assim aumentar a geração e a transferência de íons. Para tais células a carga catalítica necessária era em torno de $0,35 \mathrm{mg} \cdot \mathrm{cm}^{-2}$. Já para uma célula com eletrólito sólido (polímero), onde os materiais do eletrodo (uma mistura de carbono e platina) eram pressionados diretamente contra a superfície do polímero, as cargas catalíticas necessárias eram relativamente altas, em torno de $4,0 \mathrm{mg} \cdot \mathrm{cm}^{-2}$. Os objetivos principais eram aumentar o transporte protônico da superfície catalítica através de um eletrodo poroso de difusão gasosa até o polímero eletrólito sólido e também promover uma grande redução na quantidade de metal nobre necessária aos eletrodos usados na PEMFC. A invenção demonstrou que a adição de uma solução de $\mathrm{NAFION}^{\circledR}$, em substituição ao TEFLON $^{\circledR}$, na composição do eletrodo de difusão gasosa conseguiu atingir os objetivos mencionados. $\mathrm{O}$ inventor conclui que os eletrodos de sua invenção têm o custo predominantemente determinado pelo $\mathrm{NAFION}^{\circledR}$ e não mais pela quantidade de metal nobre utilizado como nos demais eletrodos para PEMFC. $O$ eletrodo relatado apresentava carga de $0,35 \mathrm{mgPt} . \mathrm{cm}^{-2}$.

Na patente, US 5.234.777 - Membrane catalyst layer for fuel cells, IUNI93/ - é relatado um estudo sobre eletrodo de filme fino. A invenção compreende em um processo de fabricação do conjunto membrana-eletrodos para o uso em uma célula a combustível, onde a melhoria é relativa ao uso de 
uma membrana sólida polimérica e de um filme de material condutor de prótons (com espessura menor que $10 \mu \mathrm{m}$ ) suportando o catalisador (carga de platina menor que $0,35 \mathrm{mg} \cdot \mathrm{cm}^{-2}$ ) uniformemente disperso. Tal filme é unido à membrana e, preferivelmente, apresenta espessura menor que $5 \mu \mathrm{m}$. A invenção caracteriza uma PEMFC (para uso com hidrogênio e oxigênio) constituída de um MEA com as camadas catalíticas fabricadas como unidades separadas e ligadas posteriormente à membrana. A carga de um determinado catalisador suportado na tinta é disperso uniformemente em um ionômero que seja permeável aos gases reagentes e ao transporte do íon, onde a mistura resultante apresenta-se como um filme fino. O filme fino é então transferido à superfície de uma membrana. A PEMFC é completada intensificando a estrutura porosa do eletrodo junto ao filme fino para o transporte dos gases pelo ionômero até as áreas catalíticas. A membrana e o ionômero são utilizados na forma $\mathrm{Na}^{+}$para fabricar a camada catalítica. A forma $\mathrm{Na}^{+}$do ionômero é obtida pela adição de $\mathrm{NaOH}$ em fração molar igual à solução do ionômero. Para a membrana, a forma $\mathrm{Na}^{+}$é alcançada através de banho em solução de $\mathrm{NaOH}$ com posterior enxágüe e secagem. O catalisador e um solvente são misturados uniformemente com o ionômero para produzir a tinta. A tinta é aplicada para criar uma camada sobre a superfície de uma membrana polimérica. A camada é então submetida a uma temperatura de pelo menos de $150{ }^{\circ} \mathrm{C}$ por um tempo suficiente para secar a tinta. O filme resultante e a membrana são convertidos para a forma protônica do ionômero para criar uma camada catalítica flexível, elástica e coerente sobre a membrana. O inventor menciona resultados acima de $3000 \mathrm{~mA} . \mathrm{cm}^{-2}$ a $400 \mathrm{mV}$ para uma carga de eletrodo de $0,13 \mathrm{mgPt} . \mathrm{cm}^{-2}$ operando com oxigênio pressurizado. Para esta mesma carga, porém operando com ar pressurizado a célula atingiu $1000 \mathrm{~mA} \cdot \mathrm{cm}^{-2}$ a $650 \mathrm{mV}$. A expectativa do inventor é que uma carga de $0,05 \mathrm{mgPt} . \mathrm{cm}^{-2}$ possa ser usada no ânodo sem que haja perda significativa no desempenho da PEMFC.

Na patente, US 5.861.222 - Gas diffusion electrode for membrane fuel cells and method of its production, /DEG99/ - é apresentado o desenvolvimento de um eletrodo de difusão gasosa para uso em células a combustível com membrana polimérica. Era um objetivo dos inventores melhorar os eletrodos de difusão gasosa para as células a combustível de membrana no que diz respeito a dados de desempenho durante a operação com ar (alimentado no cátodo). Outro 
objetivo era o de melhorar a operação dos eletrodos de difusão do gás controlando a interação das três fases: catalisador / eletrólito / gás. Além disso, a patente ainda dispõe sobre a criação de um método para produzir estes eletrodos de difusão gasosa com as melhorias pretendidas. Os objetivos acima foram alcançados pela construção de um eletrodo poroso de difusão gasosa para PEMFC sobre uma membrana polimérica condutora protônica. Tal eletrodo continha um eletrocatalisador finamente dividido que foi disperso sobre o polímero condutor protônico. De acordo com os aspectos preferenciais da invenção, o eletrodo de difusão de gás tem uma concentração de platina da ordem de $0,01 \mathrm{mg} \cdot \mathrm{cm}^{-2}$ a $4,0 \mathrm{mg} \cdot \mathrm{cm}^{-2}$. Outro aspecto importante desta invenção é que o eletrodo apresenta uma espessura variando de $5 \mu \mathrm{m}$ a $100 \mu \mathrm{m}$. Uma das realizações da referida patente remete à definição de um método de fabricação de eletrodos porosos de difusão gasosa para uso em PEMFC, onde a membrana é revestida com um eletrocatalisador finamente disperso e com pelo menos um material formador de poros em uma solução de um polímero condutor iônico. Como materiais formadores de poros foram sugeridos carbonatos e bicarbonatos de metais alcalinos, além de oxalato de amônia. A membrana é colocada em uma forma não ácida e estável termicamente, desta maneira é aquecida durante a deposição a uma temperatura na faixa de $130^{\circ} \mathrm{C}$ a $170{ }^{\circ} \mathrm{C}$. Depois o revestimento é secado. Segue-se a re-protonação ácida da membrana e do eletrodo. $\mathrm{O}$ material formador de poros usado numa forma finamente dividida possui uma média de tamanho de partícula da ordem de $0,1 \mu \mathrm{m}$ a $10 \mu \mathrm{m}$.

$\mathrm{Na}$ patente, US 5.869.416 - Electrode ink for membrane electrode assembly, /DOW99/ - são relatados processos de fabricação de uma tinta catalítica e de MEA. Foi observado que a composição e o processo inventados produzem MEAs que alcançam relativos altos potenciais a uma dada densidade de corrente e vazão de gás na célula a combustível. A tinta é formada basicamente por partículas ativas de catalisador, um composto orgânico e um ligante polimérico. O termo "partículas ativas de catalisador" é utilizado como referência a um metal ou composto que catalisa a eletro-redução do oxigênio ou a eletro-oxidação do hidrogênio ou metanol sob as condições de temperatura e pressão da célula a combustível. As partículas podem ser suportadas em um material apropriado como o negro de fumo (carbon black). O inventor acredita que a melhoria do desempenho resulta da capacidade do composto orgânico de ser 
facilmente volatilizado quando aquecido, situação que poderia acontecer em função da baixa incidência de ligações iônicas, de hidrogênio, covalentes ou parciais formadas entre o composto orgânico e o ligante polimérico, particularmente, quando este ligante está na forma iônica. Acredita-se também, que a facilidade com que o composto orgânico pode ser retirado da tinta, influencia significativamente as características de porosidade da camada catalítica resultante. A porosidade afeta diretamente o transporte de água através da camada, o que afeta fortemente o desempenho do MEA. Além disso, se a tinta da invenção for aplicada diretamente sobre a membrana, não causará a esta um inchaço excessivo, já que o composto orgânico não formará ligações significativas com o ionômero da membrana. Compostos orgânicos apropriados incluem aqueles que apresentarem um pKa (logaritmo negativo de base 10 da constante de equilíbrio, $\mathrm{K}$, da reação entre o composto e a água) pelo menos perto de 18 e um parâmetro de basicidade, $\beta$, menor que 0,66. O processo descrito de fabricação do MEA consiste em três passos básicos: 1- Aplicação de uma camada da composição (tinta) sobre uma membrana polimérica ou sobre outro substrato (papel de fibras de carbono, molde de Teflon ${ }^{\circledR}$ com fibra de vidro); 2Aquecimento do conjunto sob condições suficientes para evaporar pelo menos 95\% do componente orgânico e; 3- Caso a tinta não tenha sido aplicada diretamente sobre a membrana, promove-se a formação do MEA. Em um dos experimentos de exemplo o invento alcançou uma densidade de corrente maior que $1000 \mathrm{~mA} \cdot \mathrm{cm}^{-2}$ a $600 \mathrm{mV}$ em célula de $9 \mathrm{~cm}^{2}$ de área ativa operando com hidrogênio e ar, com cargas de platina de $0,14 \mathrm{mg} \cdot \mathrm{cm}^{-2}$ e $10 \mu \mathrm{m}$ de espessura no ânodo e $0,25 \mathrm{mg} \cdot \mathrm{cm}^{-2}$ e $17 \mu \mathrm{m}$ no cátodo.

Na patente, US 5.871.860 - Manufacture of electrodes, /JOH99/ - é relatado um processo de fabricação de um eletrodo não uniforme para a célula a combustível. Os inventores realizam um breve histórico de patentes no mundo sobre processos de fabricação de eletrodos ressaltando que, embora diferentes técnicas sejam utilizadas, um objetivo comum em todas elas é a formação de uma camada homogênea ao longo da área ativa. Mesmo aqueles processos que visavam obter diferentes camadas na direção dos canais de gás para o eletrólito, tinham o objetivo de que cada camada ao longo de sua área deveria ser homogênea. Ao fazerem tal histórico os inventores esclarecem que os canais de gases podem apresentar perfis que promovem um gradiente de composição e 
temperatura dos gases reagentes ao longo de seu caminho do bocal de entrada até o de saída. Segundo eles, isto ocorre pelo consumo do gás reagente e formação de produto ao longo deste caminho. Assim é proposta a criação de um eletrodo de múltiplas camadas na direção do caminho dos gases, onde a carga de catalisador possa ser definida em função do gradiente de composição e de temperatura dos gases reagentes em seu trajeto. $O$ invento proposto sugere uma melhoria do desempenho da célula uma vez que o catalisador é mais bem utilizado no novo eletrodo não uniforme. A não uniformidade do eletrodo é obtida pelo aumento da concentração do eletrocatalisador ao longo de um eixo do eletrodo, sendo este eixo paralelo ao substrato do eletrodo. A invenção visa solucionar esta questão quando do processo de fabricação do eletrodo. Em particular, os inventores utilizaram o método de impressão à tela para ajudar na aplicação pré-determinada e controlada das camadas do eletrodo que podem ser depositadas para coincidir com a matriz (caminho) e o gradiente do fluxo de gás.

A patente, US 20080191161 - Ink for Producing Catalyst Layers, /KAL08/ - é relativa à invenção de uma tinta para utilização na produção de camadas catalíticas para dispositivos eletroquímicos, incluindo a PEMFC. A tinta descrita contém ao menos um solvente orgânico que é estável à degradação oxidativa. Quanto aos solventes da tinta relatada na invenção, é preferível que sejam completamente miscíveis em água e com os solventes da solução de ionômero utilizada. Para produzir tal tinta, o metal eletrocatalisador, a solução de ionômero, a água deionizada e o solvente orgânico são pesados e homogeneizados. A tinta pode ser aplicada diretamente sobre membrana, GDL ou sobre outros tipos de substratos como filmes poliméricos. Segundo os inventores, é possível utilizar vários tipos de processos de deposição tais como, aspersão, pintura com pincel e impressão à tela. Após deposição, as camadas catalíticas são secas e apresentaram boa aderência a todos os substratos comumente utilizados, em particular às membranas poliméricas. Alguns exemplos de aplicação da tinta foram relatas. Exemplo 1 - Uma tinta, na proporção 2:1 de catalisador/ionômero, foi aplicada por aspersão sobre membrana comercial (NR 111 da DuPont). O MEA foi confeccionado com carga total de 0,44 mgPt.cm ${ }^{-2}$ (cátodo e ânodo), dimensões quadradas de $7,07 \mathrm{~cm}$ (área ativa de $50 \mathrm{~cm}^{2}$ ) e posteriormente seco a $90{ }^{\circ} \mathrm{C}$. Como GDL foi utilizado o TGPH-060 da Toray. A operação da célula ocorreu com hidrogênio e ar e para $762 \mathrm{mV}$ foi obtida a 
densidade de corrente de $500 \mathrm{~mA} \cdot \mathrm{cm}^{-2}$ com potência de $0,38 \mathrm{~W} \cdot \mathrm{cm}^{-2}$. Exemplo 2 - A tinta foi aplicada por impressão à tela sobre um GDL comercial (Sigracet $21 B C$ da SGL) na mesma dimensão e geometria do exemplo 1. Após a impressão os eletrodos foram secos. Uma membrana de 50 microns foi disposta entre os eletrodos para formar o MEA. A carga total de Pt utilizada foi de $0,54 \mathrm{mg} \cdot \mathrm{cm}^{-2}$. Este conjunto alcançou $500 \mathrm{~mA} \cdot \mathrm{cm}^{-2}$ a $700 \mathrm{mV}\left(0,35 \mathrm{~W} \cdot \mathrm{cm}^{-2}\right)$. Outro exemplo foi relatado para verificar a estabilidade durante a armazenagem. A tinta foi armazenada em recipiente selado por 64 dias à temperatura ambiente. Métodos de análise cromatográfica forma realizados no início e no fim do período de armazenamento. Os resultados demonstraram que não ocorreu decomposição ou degradação do solvente da tinta atestando sua alta estabilidade.

Em Internal humidifying of PEM fuel cells, /STA96/, é apresentado um estudo sobre umidificação interna de PEMFC. O autor ressalta a necessidade de se obter um eletrodo poroso. Neste caso, foi utilizada uma carga aproximada de Pt de $2,5 \mathrm{mg} \cdot \mathrm{cm}^{-2}$ a $2,8 \mathrm{mg} \cdot \mathrm{cm}^{-2}$. O substrato usado para suportar a camada catalítica foi um tecido de carbono de $0,4 \mathrm{~mm}$ de espessura. O tecido foi sinterizado juntamente com Pt, C, Teflon ${ }^{\circledR}$ e Nafion ${ }^{\circledR}$. O autor fez uma segunda célula tendo ouro $\left(16 \mathrm{mg} . \mathrm{cm}^{-2}\right)$ como eletrocatalisador. Em comparação, a célula com ouro apresentou menor resistividade, porém não foi notada grande diferença no desempenho. $O$ autor ponderou que a condutividade do eletrodo é um importante parâmetro, porém não é tão significante quanto as características de atividade catalítica e de eficiência em transporte de massa do sistema, que neste caso foram os efeitos limitantes do processo. Na opinião do autor, em função dos resultados obtidos, um fluxo rápido e turbulento supre maiores quantidades de oxigênio para o cátodo, porém com o efeito de diminuir a extração do oxigênio ou de aumentar a diferença sobre a estequiometria para mais. Para o autor este problema pode ser solucionado com a otimização dos canais de alimentação dos gases (placa bipolares) e com a melhoria dos eletrodos (porosidade e materiais). $\mathrm{Na}$ conclusão do artigo é ressaltado que o manejo da água e dos gases reportados naquele estudo apresentou vantagens para um sistema de baixa pressão, por outro lado, a configuração apresentada ficou prejudicada principalmente pela deficiência na cinética da reação.

Em PEM fuel cells for transportation and stationary power generation applications, /CLE97/, é apresentado um estudo sobre o desenvolvimento de 
PEMFC para aplicação veicular e para geração estacionária. Este artigo mostra um eletrodo confeccionado com baixa carga de $\mathrm{Pt}$ em relação aos comercialmente empregados naquela época, 1997. Os autores apresentam ainda soluções de eletrocatalisadores (Platina/Rutênio - Pt/Ru) para uso com gás de reforma e para células de metanol direto (Direct Methanol Fuel Cell - DMFC). A investigação dos autores foi principalmente sobre uma célula de $100 \mathrm{~cm}^{2}$ de área ativa, usando um MEA com teor de Pt de $0,14 \mathrm{mg} \cdot \mathrm{cm}^{-2}$ e com alimentação dos gases através de telas de aço inoxidável. A célula alcançou um desempenho de $600 \mathrm{~mA} . \mathrm{cm}^{-2}$ a $700 \mathrm{mV}$, comparável ao desempenho obtido por células comerciais à época que apresentavam 4,0 mg.cm ${ }^{-2}$ de $\mathrm{Pt}$ em seus eletrodos.

Em A novel process to fabricate membrane electrode assemblies for proton exchange membrane fuel cells, /KIM98/, é apresentado um processo de fabricação do conjunto eletrodo-membrana-eletrodo de uma PEMFC. Os autores introduzem o artigo relatando a dificuldade de contato existente entre eletrodo e eletrólito nas células a combustível com eletrólito sólido em relação às de eletrólito líquido. Também é ressaltado que para uma melhor utilização do catalisador é necessária a formação de uma tripla fase reacional (eletrólito catalisador - gás). É apresentado o seguinte método de confecção de MEAs: O pó da resina do copolímero de fluoreto do perfluorosulfonil é posto em uma tela de aço inoxidável e conformado por prensagem a quente. A tinta catalítica de $\mathrm{Pt} / \mathrm{C}$ é depositada de um lado desta folha, recém formada, pelo método de impressão à tela. A folha é seca e o processo se repete para o outro lado. Uma nova prensagem a quente e um posterior banho em solução de $\mathrm{NaOH}$ são realizados para a formação final do MEA, trazendo a membrana para sua forma de troca iônica. A carga de $\mathrm{Pt}$ foi controlada a $0,2 \mathrm{mg} \cdot \mathrm{cm}^{-2}$. Os autores chegaram a conclusão que a membrana aderiu muito bem à camada catalítica porosa.

Em Effect of channel dimensions and shape in the flow-field distributor on the performance of polymer electrolyte membrane fuel cells, /KUM02/, os autores utilizam uma ferramenta de fluido-dinâmica computacional (Fluent) para averiguar o efeito de diferentes geometrias de canal no desempenho da célula. Foi observado que uma placa bipolar com canais de $1,5 \mathrm{~mm}$ de perfil quadrado com espessura de parede de $0,5 \mathrm{~mm}$ apresenta o maior gradiente de pressão na simulação e, conseqüentemente, apresentaria o melhor resultado na prática. Além disso, foi conduzido estudo de perfis com espessura de parede tendendo a zero 
(perfil triangular e perfil arredondado). Neste último estudo os autores chegaram à conclusão que quanto menor a espessura das paredes dos canais melhor será a contribuição das placas de distribuição de gases para o aumento de desempenho da célula a combustível.

Em Fabrication of polymer electrolyte membrane fuel cell MEAs utilizing inkjet print technology, /TOW07/, os autores relatam um processo de preparação de membranas comerciais utilizando uma seqüência de banhos de uma hora de duração com $\mathrm{H}_{2} \mathrm{O}_{2}$, água deionizada, $\mathrm{H}_{2} \mathrm{SO}_{4}$ e novamente água deionizada. Após este tratamento a membrana é armazenada em água deionizada. Imediatamente antes da impressão a membrana é seca sob vácuo a $70^{\circ} \mathrm{C}$ até que retorne à suas dimensões originais. Para a pintura, os cartuchos de uma impressora comercial foram abertos, limpos e preenchidos com a tinta catalítica através de uma seringa. A membrana é presa a uma folha e posta na bandeja da impressora. O processo de impressão ocorre à temperatura ambiente onde o eletrodo é depositado em camadas. Cada camada precisa atingir um nível de secagem adequado entre as deposições. Com o final das deposições o eletrodo é seco em até $30 \mathrm{~s}$ e o processo se repete para a confecção de novo eletrodo do outro lado da membrana. Os autores ressaltam que o processo foi desenvolvido utilizando impressoras comerciais comuns relativamente baratas em comparação com outros métodos já bem estabelecidos, e com este processo foram confeccionados eletrodos de $2,25 \mathrm{~cm}^{2}$ com carga de $0,2 \mathrm{mgPt}_{\mathrm{cm}}{ }^{-2}$. Os resultados encontrados foram até $10 \%$ menores que aqueles obtidos pelo MEA comercial utilizado para comparação, porém o MEA fabricado apresentava 33\% menos carga catalítica.

A título de comparação, na tese de doutorado, Desenvolvimento de protótipos de células a combustível de $\mathrm{H}_{2} / \mathrm{O}_{2}$ de 500 e $1.000 \mathrm{~W}$, estudos e testes em células unitárias com catalisadores obtidos por processo sol-gel para oxidação direta de etanol, /SAR03/, é conduzido um estudo em célula unitária de $127,50 \mathrm{~cm}^{2}$ de área ativa com cargas de $0,5: 0,5 \mathrm{mgPt}_{\mathrm{cm}}{ }^{-2}$ nos eletrodos. A operação ocorreu com $\mathrm{H}_{2} / \mathrm{O}_{2}$ umidificados e o resultado obtido foi em torno de 28 A (aproximadamente $220 \mathrm{~mA} \cdot \mathrm{cm}^{-2}$ ) a $600 \mathrm{mV}$.

\subsection{Polarização Eletródica}

Vários fenômenos ocorrem na superfície do eletrodo sob a passagem de corrente elétrica. O potencial do eletrodo é dependente da corrente que circula 
no sistema, sendo os desvios em relação ao potencial de equilíbrio denominados de polarização eletródica /TIC05/. Existem diferentes tipos de polarização, na PEMFC as três aplicáveis são:

- Polarização por Ativação $\left(\eta^{A}\right)$ : representa a barreira energética criada para a transferência de elétrons na interface do eletrodo. Esta etapa é determinante em regiões de baixa corrente elétrica;

- Polarização por Queda Ôhmica $\left(\eta^{R}\right)$ : regida pela Lei de Ohm. Esta polarização é determinada pela condutividade protônica do eletrólito. Pode ser predominante em regiões de médias e altas correntes elétricas;

- Polarização por Concentração ou Transferência de Massa $\left(\eta^{C}\right)$ : é predominante quando a velocidade da reação é determinada pela difusão (chegada) das espécies reagentes aos sítios ativos na interface do eletrodo. Normalmente esta polarização ocorre em regiões de altas correntes. Pode ser minimizada pela operação com excesso de gases reagentes;

A polarização total é igual ao somatório de todas as polarizações que ocorrem na célula $\left(\eta_{\text {TOTAL }}=\eta^{A}+\eta^{R}+\eta^{C}\right)$.

$O$ efeito das polarizações pode ser representado através de curvas de polarização. A curva de polarização é um gráfico que representa o potencial, E, em volts $(\mathrm{V})$ ou milivolts $(\mathrm{mV})$ da célula sob solicitação de diferentes cargas, ou seja, a corrente elétrica (I) apresentada em ampéres (A) resultante. Para facilitar a comparação entre diferentes células, a corrente elétrica, I, é freqüentemente substituída pela densidade de corrente elétrica, i, apresentada em $\mathrm{mA} \cdot \mathrm{cm}^{-2}$, no eixo horizontal das curvas de polarização. O melhor desempenho é notado quando para um mesmo potencial uma determinada célula apresenta uma maior corrente elétrica, isto significa que a célula apresentou menores polarizações. Porém, devido ao acoplamento fenomenológico existente na PEMFC, a definição da melhor célula pode variar em função da região da curva escolhida para realizar a comparação. Assim, são definidos pontos de interesse como, por exemplo, o potencial de operação $\left(E_{\text {ope }}\right)$. Normalmente o potencial de operação utilizado neste tipo de célula é $E_{o p e}=600 \mathrm{mV}$, porque nesta condição consegue-se obter bom desempenho com menor degradação da membrana a longo prazo. 


\section{METODOLOGIA}

Para o desenvolvimento do método de Impressão à Tela na fabricação de eletrodos de difusão gasosa e de conjuntos eletrodos-membrana para aplicação em PEMFC foi conduzida a seguinte seqüência de passos: testar novas soluções para o processo de Impressão à Tela; comparar a morfologia de MEAs produzidos pelos processos de Impressão à Tela e de Aspersão; comparar o desempenho de MEAs de $25 \mathrm{~cm}^{2}$ de área ativa produzidos pelos dois processos; aumentar a escala dos MEAs produzidos para $144 \mathrm{~cm}^{2}$ de área ativa; comparar a Perda de catalisador existente em cada método; comparar o desempenho dos MEAs produzidos por impressão à Tela com MEAs comerciais e levantar custos associados à construção da célula unitária e à fabricação de MEAs $\left(144 \mathrm{~cm}^{2}\right)$ por Impressão à Tela. Tais passos não só estabelecem o novo método como também o posicionam em relação aos objetivos do IPEN em desenvolver células a combustível do tipo PEMFC. Os métodos utilizados para comparação da morfologia e do desempenho de MEAs são explicados antes do detalhamento dos passos apresentados acima. A seqüência de apresentação foi assim definida porque os métodos de comparação e caracterização são métodos já estabelecidos e de uso corrente em outras aplicações, enquanto que os passos mencionados aqui são específicos desta pesquisa e podem utilizar aqueles métodos como base.

\subsection{Microscopia Eletrônica de Varredura (MEV)}

O microscópio eletrônico de varredura utiliza um feixe de elétrons de alta energia que sistematicamente percorre (varre) a superfície da amostra. A interação deste feixe com a amostra gera um grande número de sinais na superfície da amostra ou perto dela. A captação destes sinais por detectores é a base para a formação da imagem da superfície da amostra. A razão principal para a utilização do MEV está associada à alta resolução que pode ser obtida (da ordem de 100) e a grande profundidade de foco (na ordem de 300 vezes melhor que o microscópio ótico). O resultado é a formação de imagens (micrografias) com aparência tridimensional (informações topográficas). 


\subsection{Curva de polarização}

As curvas de polarização foram traçadas a partir da maior corrente até o estado em circuito aberto, I igual a zero. Para cada corrente foi verificado o potencial da célula (E), representado no eixo vertical. A curva foi construída com a densidade de corrente elétrica (i) no eixo horizontal.

\subsection{Processos utilizados}

Embora os trabalhos de Baldo /BAL03/ e de Frey e Linardi /FRE04/ tenham definido e empregado o processo de Aspersão/Prensagem a Quente utilizado no Programa de Células a Combustível do IPEN, quando do início deste trabalho a prática no laboratório já havia sido modificada em função da constante busca por melhores resultados. Assim, para aproveitar todos os conhecimentos existentes no grupo de células PEM do Programa de Células a Combustível do IPEN, as informações foram organizadas na forma de um padrão - Confecção de MEAs e montagem de PEMFC. Algumas atividades presentes neste padrão foram detalhadas em padrões com maior especificidade técnica para execução prática. São eles: tratamento de membrana (Aspersão); preparação de tinta (Aspersão); pintura (Aspersão); e prensagem a quente.

\subsubsection{Confecção de MEAs e montagem de PEMFC}

A metodologia adotada para a confecção de PEMFC relaciona a escolha dos componentes do MEA, o tratamento e a confecção de cada componente, além do processo de união dos eletrodos à membrana. Tais informações estão descritas na TAB.2. No IPEN dois tipos de camada difusora (GDL) costumam ser utilizadas em função do objetivo da pesquisa. Pode-se utilizar o tecido de carbono ou o papel grafite. Esta escolha influencia processos posteriores, como por exemplo, o uso ou não da prensagem a quente. O papel grafite não costuma suportar as tensões existentes no processo de prensagem a quente. A tinta catalítica pode ser depositada diretamente sobre a membrana ou sobre a camada estrutural. Para facilitar a aderência da camada catalítica à membrana é utilizada solução de Nafion $^{\circledR}$ na tinta catalítica. Os parâmetros para a prensagem a quente devem ser compatíveis com as características do conjunto eletrodo-membrana-eletrodo, isto é, a pressão, a temperatura e o tempo, a serem aplicados devem ser modificados em função do tamanho do conjunto. 
TABELA 2 - Confecção de MEAs e montagem de PEMFC

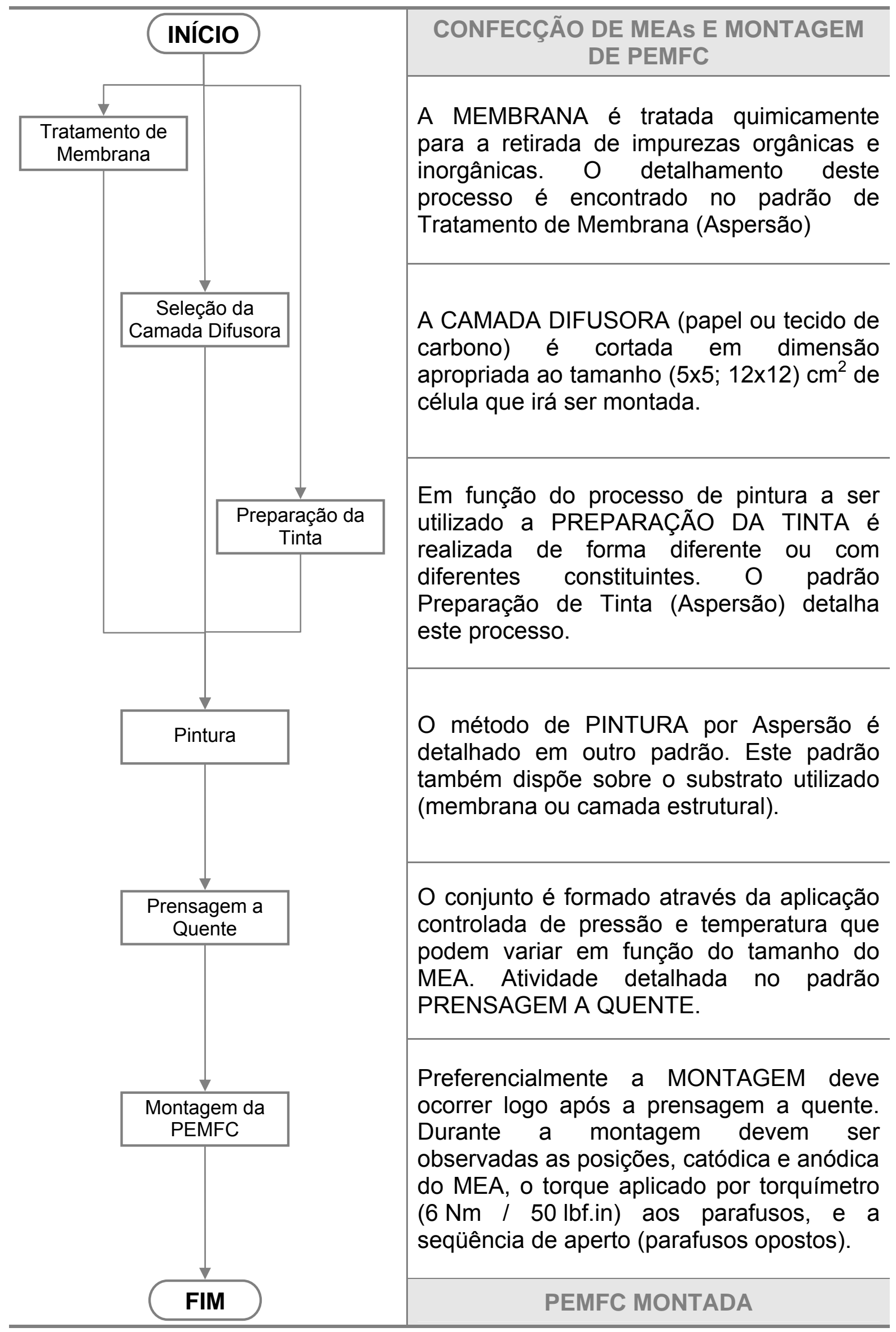




\subsubsection{Tratamento de Membrana (Aspersão)}

No caso da técnica de Aspersão, os seguintes cuidados são tomados com as membranas previamente (TAB.3).

TABELA 3 - Tratamento de Membrana (Aspersão)

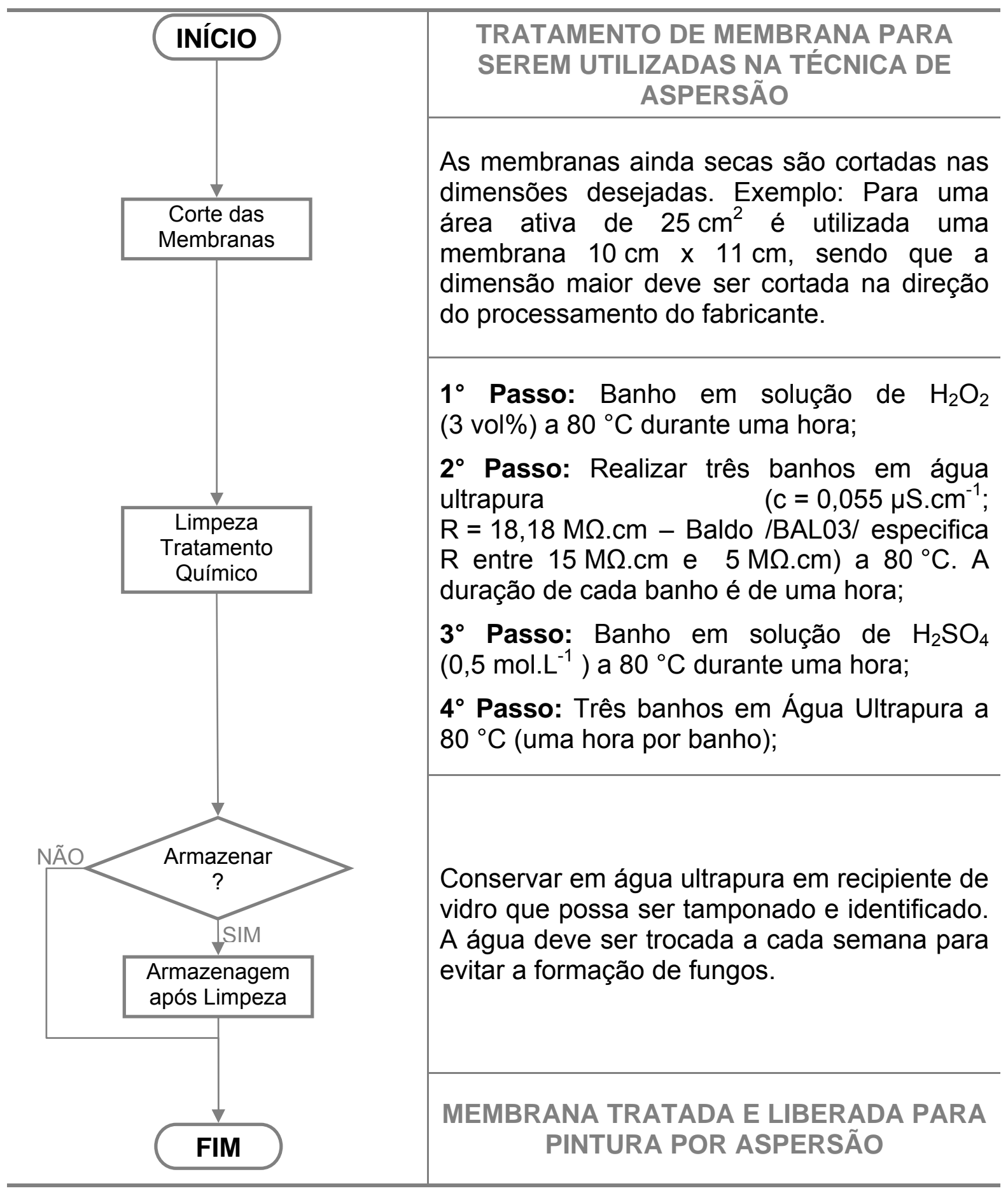

Este processo normalmente é aplicado para o tratamento de membranas comerciais. Porém, não há diferença de tratamento para diferentes especificações de membranas comerciais. 


\subsubsection{Preparação de Tinta (Aspersão)}

O processo definido na TAB.4 representa as práticas encontradas no laboratório para o desenvolvimento de eletrodos de interesse do IPEN.

TABELA 4 - Preparação de Tinta (Aspersão)

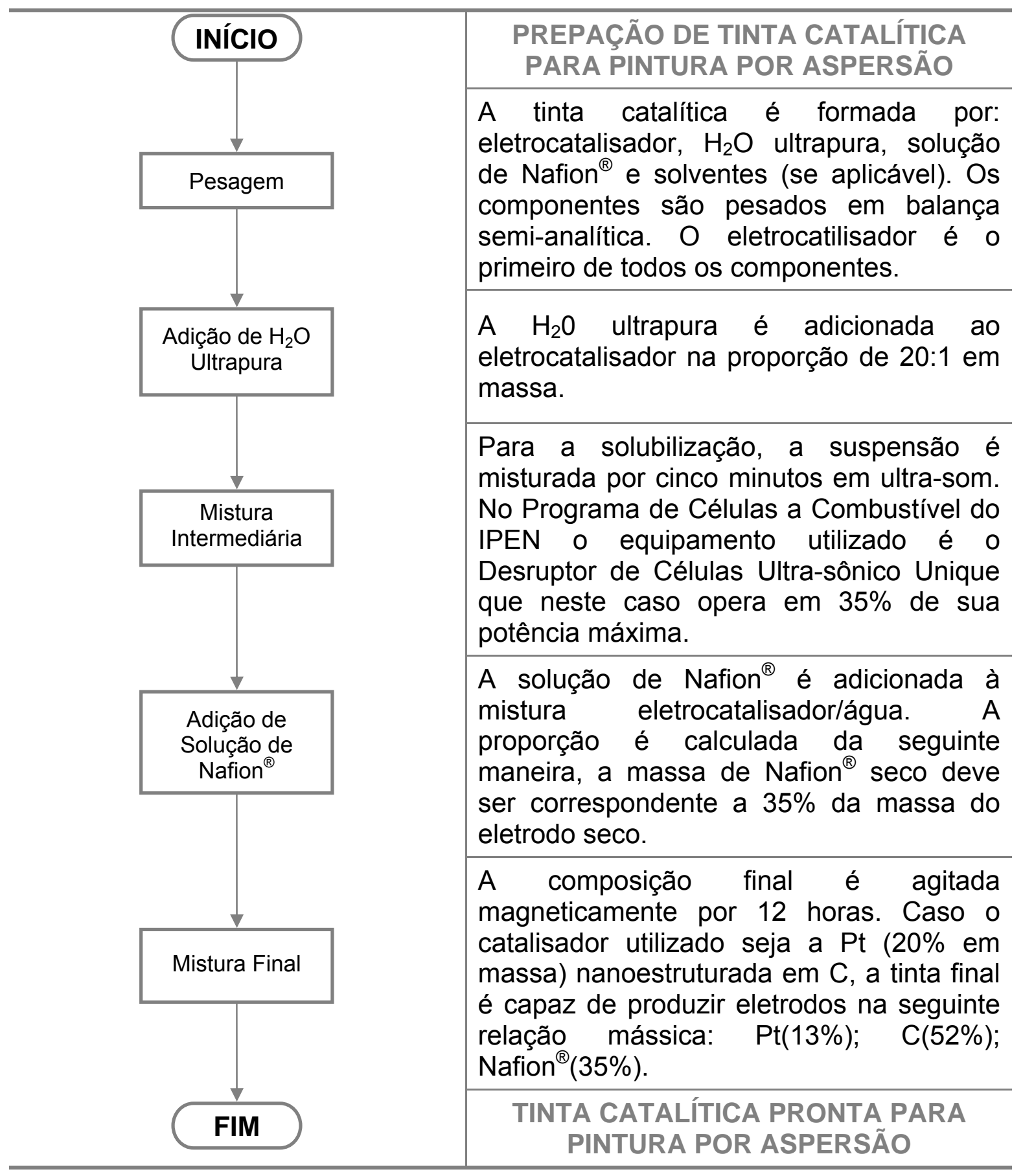

Pode ser adicionado na tinta álcool isopropílico ou acetona para facilitar o processo de pintura por Aspersão. Esta prática é utilizada para evitar entupimentos do aerógrafo. 


\subsubsection{Pintura (Aspersão)}

O processo de Aspersão sobre um substrato está descrito na TAB.5.

TABELA 5 - Pintura (Aspersão)

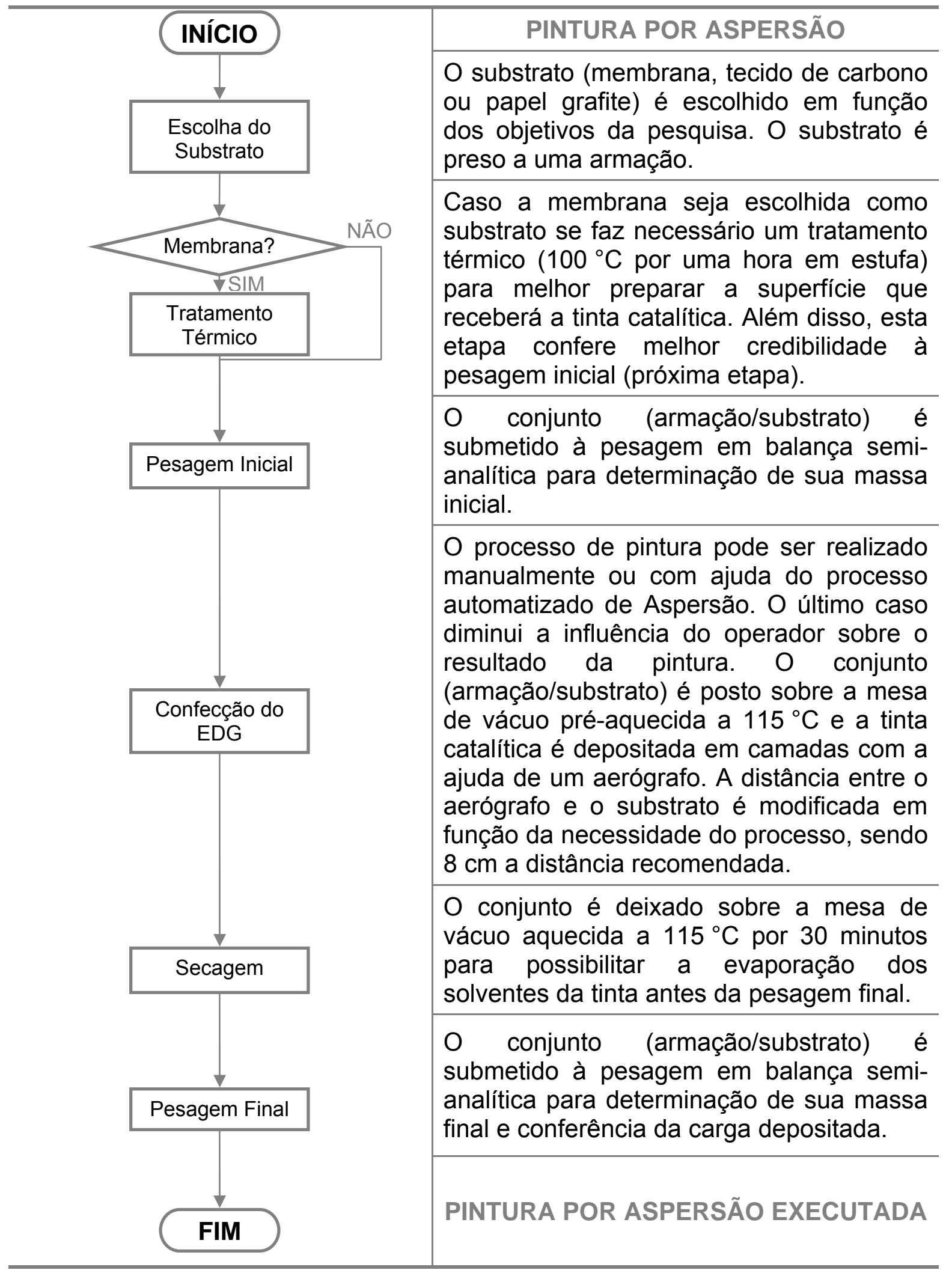


Caso seja necessário fazer o segundo eletrodo de difusão gasosa, todo o processo é repetido. Especificamente para a situação de membrana como substrato, o conjunto (armação/substrato) deve ser colocado na posição inversa da anterior (primeiro EDG) para a realização da pintura, isto é, o lado recém pintado voltado para baixo (em contato com a mesa de vácuo).

\subsubsection{Prensagem a Quente}

O processo de prensagem a quente (TAB.6) foi o que apresentou a maior diversidade de práticas no laboratório. Uma das causas desta diversidade é o fato de serem prensados MEAs de diferentes tamanhos $\left(4 \mathrm{~cm}^{2}, 5 \mathrm{~cm}^{2}, 25 \mathrm{~cm}^{2}\right.$, $49 \mathrm{~cm}^{2}$ ) exigindo assim diferentes condições de prensagem.

TABELA 6 - Prensagem a Quente

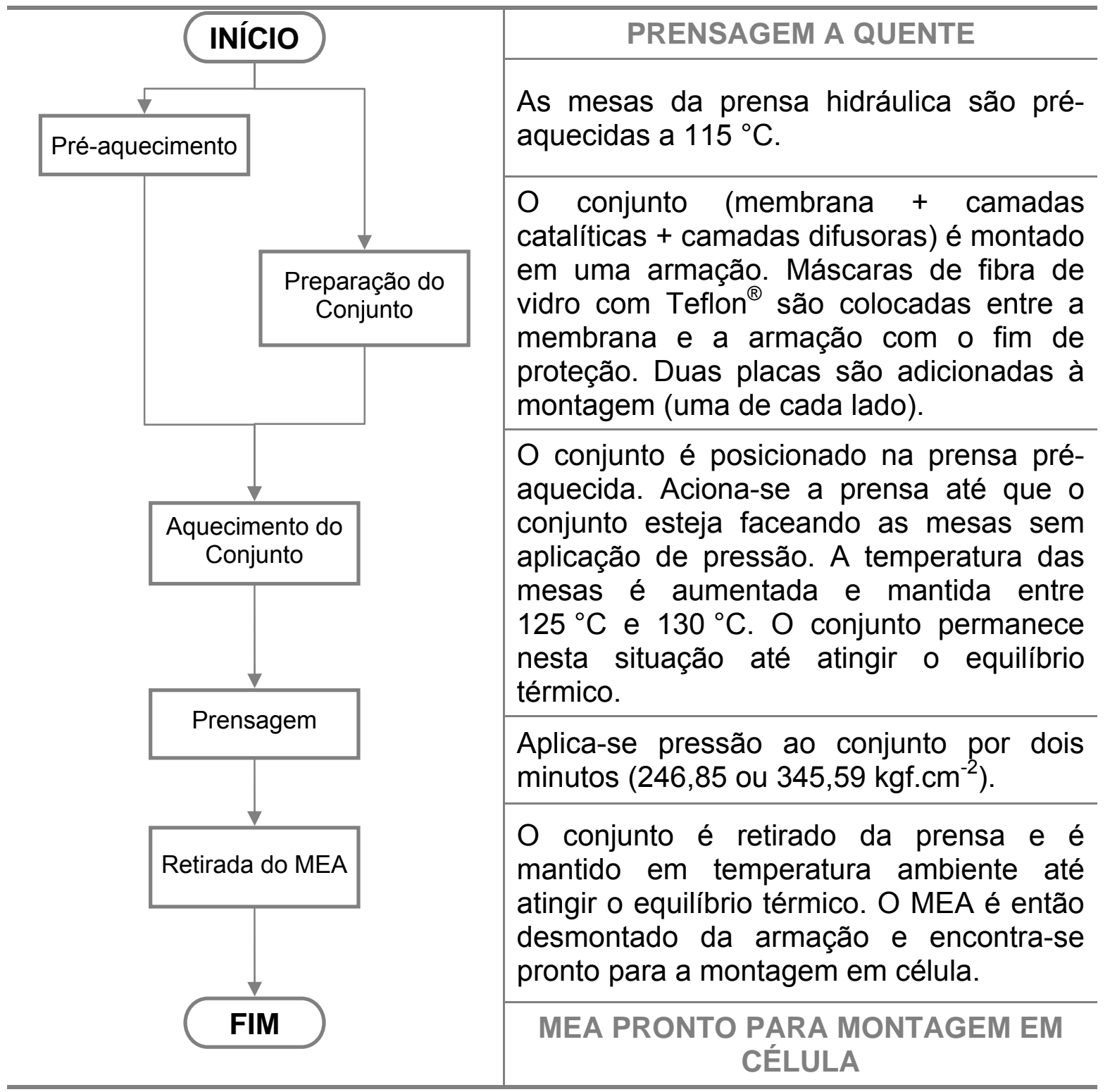




\subsection{Experiência prévia no exterior}

O Hydrogen Institute for Applied Technology - HIAT de Schwerin na Alemanha possuía prévia experiência com o processo de Impressão à Tela para fabricação de MEAs de células PEM.

Os parâmetros prévios utilizados no HIAT serviram de ponto inicial para o desenvolvimento do processo brasileiro. Porém, como o processo alemão foi desenvolvido com caráter produtivo e não científico, muitas das sugestões apresentadas tiveram que ser revalidadas, aperfeiçoadas ou descartadas através de rotinas de experimentos.

Os parâmetros relevantes desta experiência prévia estão organizados abaixo, e serviram de ponto de partida para o processo global de confecção do MEA:

- Tratamento do Eletrólito: foi sugerida a realização de tratamento térmico da membrana em estufa a $150^{\circ} \mathrm{C}$ por 30 minutos sobre placa cerâmica porosa. A limpeza da membrana (tratamento químico) seria dispensada;

- Preparação da Pasta Catalítica: os componentes da pasta, bem como seu método de preparação foram apresentados. Os componentes seriam: água ultrapura, eletrocatalisador, solução de Nafion ${ }^{\circledR} 10 \%$ em massa (tendo como solvente principal a água), e para o solvente da tinta seria utilizado o 2-[2Ethoxyethoxy] Ethyl Acetate - 2EEA. A proporção da tinta sugerida foi: $75 \%$ em massa de catalisador $(20 \%$ em massa de $\mathrm{Pt}+80 \%$ em massa de C) e $25 \%$ em massa de Nafion ${ }^{\circledR}$ considerando o eletrodo seco. A água seria adicionada na proporção de 2:1 em massa do catalisador $(\mathrm{Pt}+\mathrm{C})$. O 2EEA foi acrescentado à pasta sem uma proporção definida. O processo de preparação sugerido apresentava as etapas de pesagem, mistura (a 10.000 RPM por 15 minutos) e evaporação (com agitação magnética e aquecimento). A pasta resultante deveria apresentar $30 \%$ em massa de sólidos e consistência parecida com a de uma "maionese". Foi disponibilizada amostra da pasta catalítica fabricada no HIAT para posterior comparação visual com a desenvolvida neste trabalho;

- Processo de Impressão à Tela: recomendação para a tela - Nylon ou Poliéster, Mesh $=31 \mu \mathrm{m}$, Espessura $=55 \mu \mathrm{m}$ e $\varnothing_{\text {Filamento }}=34 \mu \mathrm{m}$. Indicada a membrana como substrato. Materiais para os rodos - Rodo de pintura em borracha e rodo de espalhamento metálico. Pressão do rodo =1,4 bar. 
Velocidade do rodo $=100 \mathrm{~mm} \cdot \mathrm{s}^{-1}$. Distância entre a mesa da máquina e a tela: para área ativa de $25 \mathrm{~cm}^{2}$ dever-se-ia utilizar $0,3 \mathrm{~mm}$ e para $144 \mathrm{~cm}^{2}$ utilizar-se-ia $0,9 \mathrm{~mm}$. Inclinação do rodo de pintura igual a $60^{\circ}$. Utilizar o modo de impressão 1 da máquina. Entre as passadas de um mesmo eletrodo foi sugerido deixar a membrana secando de cinco a dez minutos à temperatura ambiente ou sob lâmpada incandescente. Além disso, após a conclusão do primeiro eletrodo a membrana deveria receber o tratamento térmico especificado anteriormente;

- Tratamento do MEA: foi proposto realizar um tratamento químico no MEA com banho em solução de $\mathrm{HNO}_{3}$ (5\% em massa) em ebulição de 15 a 30 minutos. Após isto, lavar com água ultrapura até atingir o $\mathrm{pH} 6$;

\subsection{Procedimentos para o estabelecimento do processo de Impressão}

Para o estabelecimento do processo de impressão à tela foram realizados procedimentos prévios, como: experimento do tratamento térmico da membrana; experimento da adição de solução de Nafion ${ }^{\circledR}$ e solvente; experimento de prensagem a quente e experimento de desempenho em células de $25 \mathrm{~cm}^{2}$.

O tratamento térmico da membrana escolhido como ponto de partida foi conduzido em estufa a $150{ }^{\circ} \mathrm{C}$ por uma hora e danificou as membranas tratadas. Depois deste evento foi recomendado o tempo de trinta minutos. No IPEN um tratamento similar era realizado a $100^{\circ} \mathrm{C}$ por uma hora com membranas previamente limpas (tratamento químico). De maneira a estabelecer o melhor processo, o seguinte experimento foi organizado: Uma amostra e uma réplica foram levadas a estufa mantida entre $120^{\circ} \mathrm{C}$ e $130^{\circ} \mathrm{C}$. Tais membranas foram previamente limpas e dispostas sobre tecido de fibra de vidro com Teflon ${ }^{\circledR}$. Foram realizadas medições das massas das membranas em balança semi-analítica para diferentes tempos de permanência. Foi verificado a partir de que tempo de permanência sob tratamento térmico a massa da membrana apresentou variação desprezível. Além disso, foi verificado o aspecto visual (dimensão, cor e enrugamento).

No laboratório existiam duas opções de solução de Nafion $^{\circledR}-10 \%$ em massa em água ou $5 \%$ em massa em álcool. Além disso, era necessário verificar a real necessidade de uso do 2EEA e definir a proporção dos componentes da tinta $\left(75 \%\right.$ em massa de eletrocatalisador e $25 \%$ em massa de Nafion ${ }^{\circledR}$ seco - 
composição confeccionada no HIAT; ou $65 \%$ em massa de eletrocatalisador e $35 \%$ de Nafion $^{\circledR}$ seco - composição confeccionada no IPEN), mantendo as características que a tornam propícia para uso no processo de Impressão à Tela. Para isto, o experimento a seguir foi desenvolvido: Quatro amostras de tinta Tinta T1, com solução de Nafion $^{\circledR} 5 \%$ em massa sem 2EEA. Tinta T2, com solução de Nafion ${ }^{\circledR} 10 \%$ em massa sem 2EEA. Tinta T3, empregando solução de Nafion ${ }^{\circledR} 5 \%$ em massa com 2EEA. Tinta T4, com solução de Nafion ${ }^{\circledR} 10 \%$ em massa com 2EEA - foram preparadas conforme a composição de $65 \%$ em massa de eletrocatalisador e $35 \%$ em massa de Nafion $^{\circledR}$ seco. Esta decisão foi tomada como a mais apropriada em função dos resultados comprovados pela experiência do IPEN. Além disso, esta composição facilita a comparação posterior com o método de Aspersão. Foi utilizado carbono ao invés de eletrocatalisador com o intuito de evitar perda. A medição de massas ocorreu em temperatura ambiente em balança semi-analítica, onde para o carbono (Vulcan XC72R da Cabot) a massa almejada era de $0,5 \mathrm{~g}$. No processo de mistura foi utilizado o Dispersor Extratur Quimis a 12.000 RPM durante quinze minutos. A evaporação com aquecimento (em torno de $65^{\circ} \mathrm{C}$ ) ocorreu sob agitação magnética (o nível de agitação diminui com o aumento da evaporação da tinta).

$\mathrm{O}$ experimento de prensagem a quente foi realizado para verificar qual das práticas do laboratório (prensagem a $125^{\circ} \mathrm{C}$ com $246,85 \mathrm{kgf}_{\mathrm{cm}} \mathrm{cm}^{-2}$ ou $345,59 \mathrm{kgf.cm}^{-2}$ por dois minutos) seria a mais adequada à confecção dos novos MEAs. Dois MEAs confeccionados na máquina de impressão à tela da empresa EKRA foram utilizados para a aplicação de $246,85 \mathrm{kgf}_{\mathrm{cm}} \mathrm{cm}^{-2}$ em prensa hidráulica. Foi utilizada a tinta produzida no HIAT para confecção dos MEAs. Estes foram colocados em uma armação, umedecidos com $\mathrm{H}_{2} \mathrm{O}$ ultrapura e dispostos entre duas placas lubrificadas com grafite. Um conjunto por vez foi posicionado na prensa pré-aquecida a $115^{\circ} \mathrm{C}$. A prensa foi acionada até o conjunto facear as duas mesas sem aplicação de pressão. A temperatura das mesas foi elevada para $125^{\circ} \mathrm{C}$ e após o equilíbrio térmico foi aplicada pressão de $246,85 \mathrm{kgf.cm}^{-2}$ por dois minutos. O conjunto foi retirado da prensa e posto para esfriar em temperatura ambiente. Depois disto, o conjunto foi desmontado da armação. $O$ processo foi repedido para o segundo conjunto. Por avaliação visual foi verificado se os MEAs apresentaram descolamento da camada difusora, enrugamento na 
área ativa ou alguma outra característica que pudesse comprometer o desempenho em célula.

Para verificar se a composição da tinta afeta o desempenho dos MEAs fabricados por Impressão à Tela, foi necessário comparar as curvas de polarização para os MEAs fabricados com as diferentes tintas, sem variar os demais parâmetros envolvidos nas etapas de confecção e operação. Foram aproveitados os resultados dos três experimentos anteriores para definir as condições deste experimento.

Em função da observação do comportamento das tintas durante a feitura as considerações que se seguem foram feitas para guiar o experimento em célula: Utilizar eletrocatalisador E-TEK 20\% HP Pt sobre vulcan XC-72R mantendo a composição de $65 \%$ em massa de eletrocatalisador para $35 \%$ de Nafion $^{\circledR}$ no eletrodo seco a fim de se verificar o efeito em operação; Verificar existência de ganho em desempenho pelo uso de uma solução de Nafion ${ }^{\circledR}$ específica (10\% em massa ou $5 \%$ em massa) e verificar a real necessidade de uso do solvente 2EEA, este componente poderia ser excluído em função de sua toxidade. Também foram utilizadas as sugestões do experimento de tratamento térmico da membrana já que apresentaram bons resultados.

Três composições de pasta catalítica foram testadas. Foram confeccionados dois MEAs (prova e contraprova) para cada composição. A pintura foi realizada sobre membrana comercial (Nafion ${ }^{\circledR} 115$ ). O tratamento químico da membrana ocorreu conforme padrão do laboratório e os tratamentos térmicos $\left(120^{\circ} \mathrm{C}\right.$ em estufa por 30 minutos com utilização de moldura) foram executados antes de pintar, após a pintura da primeira face e antes do tratamento químico do MEA. Foi utilizado catalisador comercial (E-TEK 20\% HP Pt sobre vulcan XC-72R) e a composição de 65\% em massa de E-TEK e 35\% em massa de Nafion ${ }^{\circledR}$ seco foi adotada. As tintas foram preparadas conforme TAB.7.

TABELA 7 - Composição das Tintas $\left(25 \mathrm{~cm}^{2}\right)$

\begin{tabular}{c|c|c|c}
\hline TEMPO $(\mathbf{h})$ & Sol. de Nafion $^{\circledR}$ & 2EEA & Água \\
\hline $102 E A$ & $10 \%$ em massa & Sim & Sim \\
\hline $52 E S$ & $5 \%$ em massa & Sim & Não \\
\hline $5 S S$ & $5 \%$ em massa & Não & Não \\
\hline
\end{tabular}


A carga almejada para os MEAs foi de $0,4 \mathrm{mgPt} . \mathrm{cm}^{-2}$ para o ânodo e $0,6 \mathrm{mgPt}_{\mathrm{cm}}{ }^{-2}$ para o cátodo. Foi utilizada uma secagem do MEA sob lâmpada incandescente (cinco minutos com peso) entre as passadas de um mesmo eletrodo. O tratamento químico do MEA com banho em ebulição de solução de $\mathrm{HNO}_{3} 5 \%$ em massa de 15 minutos a 30 minutos e posterior lavagem com água ultrapura em temperatura ambiente até atingir o pH 6 foi adotado. Foi escolhido o tecido de carbono comercial (E-TEK - tratado com $30 \%$ de Teflon $^{\circledR}$ ) como camada difusora. A prensagem a quente ocorreu com $345,59 \mathrm{kgf}_{\mathrm{cm}} \mathrm{cm}^{-2}$ de pressão. Os MEAs foram testados no painel de operações do laboratório de PEMFC do IPEN, tendo sido utilizada a carga dinâmica TDI (RBL488 50-150-800 - com faixa de operação entre $0 \mathrm{~V}$ e $50 \mathrm{~V}, 0$ A e 150 A e $0 \mathrm{~W}$ a $800 \mathrm{~W}$ ) e um multímetro para a realização das medições em bancada. Foi utilizada uma célula de $25 \mathrm{~cm}^{2}$ da Eletrochem, alimentada com hidrogênio e oxigênio puros com o dobro da estequiometria em cada potencial percorrido na curva de polarização. Somente o ânodo foi umidificado a $85^{\circ} \mathrm{C}$. A temperatura de operação da célula girou em torno de $70^{\circ} \mathrm{C}$. Foram construídas e comparadas de três a quatro curvas (de polarização e de potência) por MEA, além de serem verificadas a corrente e a densidade de corrente a $600 \mathrm{mV}$ e na potência máxima. Foram também levantadas as resistências dos MEAs a partir de regressão linear da dispersão de pontos da região de queda ôhmica das curvas de polarização. A tangente do ângulo entre a reta de regressão linear e o eixo horizontal corresponde ao coeficiente de inclinação desta reta e seu módulo representa a resistência do conjunto, $\boldsymbol{r}$, apresentada em $\mathrm{m} \Omega . \mathrm{cm}^{2}$. Para a construção da reta de regressão linear e cálculo do coeficiente de inclinação foi utilizado o Microsoft ${ }^{\circledR}$ Office Excel 2003.

\subsection{Comparação entre os métodos de Impressão à Tela e Aspersão}

Para verificar se a técnica de impressão à tela estabelecida é capaz de produzir MEAs apropriados aos interesses do IPEN, foram realizadas comparações morfológicas dos MEAs produzidos tanto por Impressão à Tela como por Aspersão, além de comparações de desempenho em células de $25 \mathrm{~cm}^{2}$ dos MEAs produzidos pelos dois métodos.

A microscopia eletrônica de varredura foi utilizada para avaliar a morfologia dos eletrodos pintados pelas duas técnicas. Dois MEAs 
confeccionados por Aspersão (um prensado e outro sem prensar) e dois MEAs por Impressão à Tela (um prensado e outro sem prensar) foram comparados. Foram realizadas micrografias de superfície e da seção transversal do MEA (com e sem GDL) em equipamento do IPEN/CCTM, que é um Microscópio Eletrônico de Varredura PHILIPS modelo XL30 com feixe de elétrons de $20 \mathrm{KeV}$ equipado com EDAX DX-4. As imagens foram comparadas visualmente.

Para comparar o desempenho dos MEAs fabricados por Impressão à Tela com aqueles fabricados por Aspersão, algumas adaptações no método de Aspersão foram necessárias. A seguir seguem as definições deste experimento: Dois MEAs com tratamento químico e outros dois sem, foram confeccionados pelo processo automatizado de Aspersão. A pintura foi realizada sobre membrana comercial (Nafion ${ }^{\circledR} 115$ ) e o tratamento químico desta ocorreu conforme padrão do laboratório. Os tratamentos térmicos das membranas $\left(100^{\circ} \mathrm{C}\right.$ em estufa por trinta minutos com utilização de moldura) foram executados antes de pintar, após pintura da primeira face e após conclusão da pintura dos eletrodos. Usado o catalisador comercial (E-TEK 20\% HP Pt sobre vulcan XC-72R) em composição de $65 \%$ em massa de E-TEK e $35 \%$ em massa de Nafion ${ }^{\circledR}$ seco. A tinta catalítica foi preparada com a solução de Nafion $^{\circledR} 5 \%$ em massa conforme padrão do laboratório. As carga dos MEAs foram de $0,4 \mathrm{mgPt} . \mathrm{cm}^{-2}$ no ânodo e de $0,6 \mathrm{mgPt} . \mathrm{cm}^{-2}$ para o cátodo. O tratamento químico do MEA foi realizado com banho em ebulição de solução de $\mathrm{HNO}_{3} 5 \%$ em massa de 15 minutos a 30 minutos e posterior lavagem com água ultrapura em temperatura ambiente até atingir o pH 6. Tecido de carbono comercial (E-TEK - tratado com 30\% de Teflon $^{\circledR}$ ) foi adotado como camada difusora. Os MEAs foram prensados a $345,59 \mathrm{kgf} . \mathrm{cm}^{-2}$. A alimentação de gases puros, com o dobro da estequiometria em cada potencial percorrido na curva de polarização, ocorreu com umidificação somente para o ânodo $\left(85^{\circ} \mathrm{C}\right)$. A temperatura da célula foi igual a $70^{\circ} \mathrm{C}$. Para este experimento foram utilizados: a célula de $25 \mathrm{~cm}^{2}$ da Eletrochem, o painel de operações do laboratório de PEMFC do IPEN, a carga dinâmica TDI (RBL488 50150-800 - com faixa de operação entre 0 V e 50 V, 0 A e 150 A e 0 W a 800 W) e um Multímetro.

Foram construídas de três a quatro curvas por MEA. A corrente e a densidade de corrente a $600 \mathrm{mV}$, além da potência máxima alcançada e a resistência dos conjuntos foram verificados. As curvas (de polarização e de 
potência) e os resultados obtidos foram comparados com aqueles obtidos pelos MEAs confeccionados por Impressão à Tela.

\subsection{Aumento de escala dos MEAs produzidos}

A área ativa definida foi a de $144 \mathrm{~cm}^{2}$ por estar alinhada com outras pesquisas de interesse do laboratório (construção do módulo de $1 \mathrm{kWe}$ de potência com $144 \mathrm{~cm}^{2}$ de área ativa). Para que o aumento de escala fosse possível algumas barreiras tiveram que ser transpostas. Não havia no laboratório uma célula unitária preparada para receber um MEA deste tamanho e as etapas do processo de Impressão à Tela teriam que ser re-estruturadas para atender as necessidades da pintura de $144 \mathrm{~cm}^{2}$. Assim, os passos percorridos para o aumento de escala foram: projeto célula unitária; tratamento térmico; preparação da pasta; adequação da altura da mesa; secagem entre passadas; prensagem a quente; e produção por um operador. Estas etapas são descritas a seguir.

\subsubsection{Projeto célula unitária}

Foi necessário o desenvolvimento de placas de grafite e placas metálicas para a composição da célula unitária. $O$ projeto da placa de grafite é o mais relevante e, desta maneira, serviu de guia para o projeto das placas metálicas. $O$ interesse era 0 de desenvolver um perfil de canal de gases que maximizasse a área de acesso dos gases à camada difusora. A base para $\mathrm{o}$ projeto da placa de grafite foi um estudo de fluido dinâmica de gases em diferentes perfis de canais de distribuição. Este estudo foi realizado com auxílio de uma ferramenta de Fluído Dinâmica Computacional - FDC (COMSOL Multiphysics). O movimento dos gases é descrito pelas equações de NavierStokes (18) e de Continuidade (19).

$$
\begin{array}{lc}
\text { Navier-Stokes: } \quad & \rho \frac{\partial u}{\partial t}-\nabla \cdot \eta\left(\nabla u+(\nabla u)^{T}\right)+\rho(u . \nabla) u+\nabla p=0 \\
\text { Continuidade: } & \nabla \cdot u=0
\end{array}
$$

Onde $\rho$ é a densidade $\left(\mathrm{kg} \cdot \mathrm{m}^{-3}\right), \boldsymbol{\eta}$ representa a viscosidade $\left(\mathrm{N} . \mathrm{s} \cdot \mathrm{m}^{-2}\right), u$ é a velocidade $\left(\mathrm{m}_{\mathrm{s}} \mathrm{s}^{-1}\right)$ e $p$ é a pressão dada em pascal. Para a camada difusora foi utilizada uma permeabilidade igual a $10^{-12} \mathrm{~m}^{2}$, a mesma utilizada por /KUM02/. A 
simulação utilizou o hidrogênio a pressão atmosférica com velocidade de entrada de 1,4 m.s ${ }^{-1}$ em três perfis, mostrados na FIG.8 (dimensões em mm).

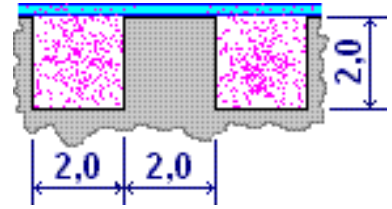

(a)

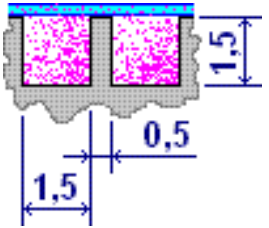

(b)

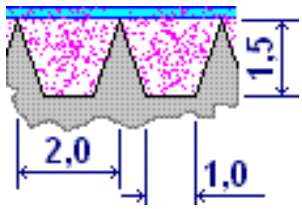

(c)

FIGURA 8 - Perfis de Canais de Gás: (a) PQ20, (b) PQ15 e (c) PT.

As áreas azuis na FIG.8 representam as camadas difusoras e as partes cinza são as placas de grafite. O lilás representa a passagem de gás pelo canal até a camada difusora. O perfil (a) existia no laboratório em placas destinadas a construção de um módulo de potência. Os perfis (b) e (c) foram desenvolvidos neste trabalho no intuito de melhorar o desempenho da célula a combustível.

Foi considerada operação em pressão atmosférica e temperatura de célula de $75^{\circ} \mathrm{C}$. Para os três perfis apresentados foram verificados: perfis de velocidade na direção z; gradiente de pressão; e áreas de estagnação (zona morta - velocidade na direção $z$ igual a zero) em regiões da camada difusora.

A direção z corresponde ao fluxo de gás no sentido da base do canal para camada difusora e vice versa.

Após definição do perfil do canal, a metodologia adotada para o projeto e desenvolvimento da célula unitária foi a seguinte: levantamento de entradas de projeto e desenvolvimento; execução do projeto; verificação das saídas de projeto e desenvolvimento; construção da célula unitária conforme projeto; e verificação de funcionalidades da Célula Unitária.

Como premissas (dados de entradas) deste projeto foram levantadas intenções de aplicação, materiais, dimensões, funcionalidades e critérios de desempenho. Para o projeto da célula unitária de $144 \mathrm{~cm}^{2}$ foram utilizadas as informações de entrada levantadas e uma ferramenta de CAD (Autocad 2006 Autodesk). Os projetos foram compatibilizados entre si e confrontados com os dados de entrada para verificar o atendimento de requisitos específicos. Para a construção, foram compradas placas brutas de materiais que atendessem às necessidades do projeto, além de anéis de vedação, resistências de aquecimento, conexões de engate rápido, parafusos, porcas e buchas. Após a construção foi verificado o funcionamento da vedação e do sistema de aquecimento. 


\subsubsection{Tratamento térmico}

Com o aumento de escala percebeu-se a dificuldade de se manter a membrana de $144 \mathrm{~cm}^{2}$ esticada durante o processo de tratamento térmico sem gerar danos (rasgos) à membrana. Para resolver este problema algumas soluções de fixação foram testadas. Foram aproveitados os resultados do experimento de tratamento térmico realizado para $25 \mathrm{~cm}^{2}$. Três membranas previamente limpas foram dispostas sobre tecido de fibra de vidro com Teflon $^{\circledR}$ e três formas diferentes de mantê-las esticadas foram testadas (presa a uma armação, com diversos pequenos pesos e com uma moldura quadrada vazada no centro como peso). A tinta produzida e utilizada no experimento foi a 52ES (com solução de Nafion ${ }^{\circledR} 5 \%$ em massa com 2EEA e sem água), porém foi substituído o eletrocatalisador por carbono (Vulcan XC72R da Cabot). A estufa foi mantida a $125^{\circ} \mathrm{C}$. Foi verificado o aspecto visual das membranas (cor, enrugamento e danos) após o tratamento.

\subsubsection{Preparação da pasta}

Para obter uma pasta que atendesse as necessidades de impressão de vários MEAs com área ativa de $144 \mathrm{~cm}^{2}$ o método de produção de tinta precisava ser otimizado. Desta maneira, foram realizados os seguintes experimentos: Primeiramente foi preparada tinta similar à utilizada no experimento de tratamento térmico $\left(144 \mathrm{~cm}^{2}\right)$, porém foi aumentada a quantidade produzida - carbono (10 g de Vulcan XC72R da Cabot) com solução de Nafion ${ }^{\circledR} 5 \%$ em massa $(107,70 \mathrm{~g}) \mathrm{e}$ 2EEA $(5 \mathrm{~g})$. A composição da tinta 52ES foi modificada para acrescentar água ultrapura $(10 \mathrm{~g}+5 \mathrm{~g})$. Para que houvesse posterior aproveitamento da tinta, no segundo experimento foi introduzido o eletrocatalisador (E-TEK 20\% HP Pt sobre vulcan XC-72R) no lugar do carbono, água ultrapura foi adicionada em solução 2:1 com o 2EEA ( $15 \mathrm{~g}$ de água para $7,5 \mathrm{~g}$ do solvente) e a massa almejada de solução de $\mathrm{Nafion}^{\circledR}$ era de $108 \mathrm{~g}$. Para o último experimento a quantidade dos componentes foi duplicada em relação ao segundo. A medição das massas ocorreu em temperatura ambiente e o processo de mistura foi conduzido a 12.000 RPM durante 15 minutos para as tintas com $10 \mathrm{~g}$ de carbono e $10 \mathrm{~g}$ de eletrocatlisador, e para a tinta com $20 \mathrm{~g}$ de eletrocatalisador foi utilizado o tempo de 30 minutos. A evaporação com aquecimento (aproximadamente $65^{\circ} \mathrm{C}$ ) sob agitação magnética (o nível de agitação diminui com o aumento da evaporação da 
tinta) foi mantida igual em todos os experimentos. As pastas foram comparadas com as anteriores. Além disso, foi verificada a qualidade da deposição na máquina de Impressão à Tela.

\subsubsection{Adequação da altura da mesa}

Para se manter a qualidade de impressão apresentada na pintura de MEAs de $25 \mathrm{~cm}^{2}$, o Snap Off da máquina (altura da mesa - distância entre a mesa e a tela) deve ser adequado para a impressão em $144 \mathrm{~cm}^{2}$. Inicialmente, foi realizada uma impressão de área de $144 \mathrm{~cm}^{2}$ sobre papel em branco (folha A4). Em seguida, foi ajustada a distância entre a mesa e a tela para a realização da pintura a fim de se obter extremidades bem definidas principalmente nos vértices do quadrado.

\subsubsection{Secagem entre passadas}

No processo de confecção dos MEAs existe uma etapa de secagem das membranas entre as deposições (passadas) de camadas da pasta catalítica de um mesmo eletrodo. Na fase de pintura de $25 \mathrm{~cm}^{2}$ de área ativa foi utilizada uma lâmpada incandescente em tal processo. Quando da fase de $144 \mathrm{~cm}^{2} \mathrm{o}$ processo de secagem entre passadas foi avaliado. Um experimento em estufa com circulação foi conduzido a $60^{\circ} \mathrm{C}$ e outro a $80^{\circ} \mathrm{C}$. Um último experimento foi realizado com um banco de lâmpadas incandescente. As membranas foram comparadas visualmente.

\subsubsection{Prensagem a Quente}

Com o aumento de escala fez-se necessário averiguar a adequação do processo de prensagem a quente, até então utilizado para os MEAs de $25 \mathrm{~cm}^{2}$ de área ativa. Dois MEAs confeccionados por Aspersão e dois MEAs por Impressão à Tela foram prensados. Os conjuntos de eletrodos-membrana foram dispostos entre duas placas de alumínio $(12 \times 12) \mathrm{cm}^{2}$ lubrificadas com grafite nas faces de contato com os conjuntos. Na prensa hidráulica com aquecimento foi averiguada

a aplicação de $345,59 \mathrm{kgf} . \mathrm{cm}^{-2}$ por dois minutos, $444,33 \mathrm{kgf.} \mathrm{cm}^{-2}$ por dois minutos e $444,33 \mathrm{kgf} . \mathrm{cm}^{-2}$ por cinco minutos. Os MEAs foram avaliados visualmente quanto à presença de áreas descoladas logo após processo de prensagem a quente. 


\subsubsection{Produção por um operador}

Este experimento teve a finalidade de se verificar a possibilidade de um único operador produzir MEAs de $144 \mathrm{~cm}^{2}$ na máquina de Impressão à Tela. Um lote, com duas membranas, foi utilizado para confeccionar os conjuntos codificados como Sie144_03 e Sie144_04. A carga de platina depositada na camada catalítica dos eletrodos foi de $0,4: 0,4 \mathrm{mg} \cdot \mathrm{cm}^{-2}$. Neste experimento a máquina foi operada somente por um operador. Para isto, utilizaram-se as conclusões de todos os outros experimentos realizados até então. A tinta utilizada foi preparada conforme processo já consolidado de preparação da pasta catalítica. Foi realizado um tratamento térmico nas membranas antes do início do processo de pintura, após conclusão do primeiro eletrodo e ao final do segundo EDG. A secagem entre passadas foi realizada sob banco de lâmpadas.

\subsection{Estimativa de Perdas}

Os dois métodos abordados neste trabalho, Impressão à Tela e Aspersão, apresentam perdas inerentes ao processo de execução. Este experimento objetivou uma comparação em relação à perda dos componentes custosos da tinta catalítica (Platina e Nafion ${ }^{\circledR}$ ). Três lotes de MEAs foram preparados. O primeiro e o segundo lotes foram de quatro MEAs e o terceiro lote de dois MEAs. Todos os lotes foram confeccionados por Impressão à Tela. Os processos foram executados segundo os melhores resultados obtidos nos experimento predecessores. Foram medidas as massas, inicial e final, do recipiente com tinta catalítica e a massa dos eletrodos depositados. Foi considerado um percentual de evaporação do solvente. Por fim, houve uma comparação entre as estimativas de perda do processo de Impressão à Tela e a utilizada no laboratório para o processo de Aspersão (100 \% - a tinta é preparada em dobro).

\subsection{Curva de Polarização - Impressão à Tela vs Aspersão vs Comercial}

MEAs de $144 \mathrm{~cm}^{2}$ de área ativa produzidos pelos dois métodos, Impressão à Tela e Aspersão, foram comparados com MEAs comerciais quanto ao desempenho em bancada.

Foi realizada a pintura sobre membrana comercial (Nafion $\left.{ }^{\circledR} 115\right)$ tratada quimicamente conforme padrão do laboratório. Um tratamento térmico da 
membrana $\left(100{ }^{\circ} \mathrm{C}\right.$ em estufa por 30 minutos com utilização de moldura para o processo de Aspersão e $120^{\circ} \mathrm{C}$ por 30 minutos para o método de Impressão à Tela) foi realizado antes de pintar, bem como, após pintura da primeira face e também após a conclusão da pintura dos eletrodos. Foi utilizado o catalisador comercial E-TEK 20\% HP Pt sobre vulcan XC-72R. Respeitada a composição de $65 \%$ em massa de E-TEK e $35 \%$ em massa de Nafion ${ }^{\circledR}$ seco. A tinta catalítica foi preparada com a solução de Nafion $^{\circledR} 5 \%$ em massa conforme padrão do laboratório para o processo de Aspersão. Um tratamento químico com banho em ebulição de solução de $\mathrm{HNO}_{3} 5 \%$ em massa de 15 a 30 minutos e posterior lavagem com água ultrapura em temperatura ambiente até atingir o $\mathrm{pH} 6$ foi realizado em todos os MEAs produzidos. Foi escolhido um tecido de carbono comercial E-TEK - tratado com 30\% de Teflon $^{\circledR}$ - como GDL. A prensagem ocorreu a $444,33 \mathrm{kgf} . \mathrm{cm}^{-2}$ por cinco minutos. O conjunto foi disposto entre placas de alumínio $(12 \times 12) \mathrm{cm}^{2}$ lubrificadas com grafite nas faces de contato.

Os dois MEAs com carga nominal 0,4:0,6 $\mathrm{mgPt}_{\mathrm{cm}}{ }^{-2}$ que foram pintados pelo método de Aspersão para o experimento de prensagem a quente foram aproveitados para a comparação de desempenho com os conjuntos eletrodosmembrana confeccionados por Impressão à Tela. Durante o processo de confecção dos MEAs por Aspersão ocorreram alguns problemas operacionais. O aerógrafo entupiu constantemente o que ocasionou consumo de tempo. A mesa de vácuo com aquecimento não atingiu a temperatura recomendada para este processo de pintura $\left(115^{\circ} \mathrm{C}\right)$. A temperatura da mesa variou de $78^{\circ} \mathrm{C}$ a $88^{\circ} \mathrm{C}$. A membrana foi levada à estufa $\left(125^{\circ} \mathrm{C}\right.$ por 10 minutos) diversas vezes para diminuir a rugosidade.

Vários conjuntos eletrodos-membrana foram preparados por Impressão à Tela para os experimentos de prensagem a quente e de produção por um operador. Três destes MEAs com carga nominal de 0,4:0,4 mgPt.cm ${ }^{-2}$ foram ensaiados em bancada e o desempenho medido foi comparado. Mais dois MEAs foram confeccionados por Impressão à Tela especialmente para o experimento de desempenho. No caso dos dois últimos MEAs confeccionados por Impressão à Tela foram utilizadas placas de alumínio de $(15,1 \times 15,1) \mathrm{cm}^{2}$ na prensagem a quente. Além disso, os tecidos de carbono utilizados nestes conjuntos foram previamente imersos em água ultrapura antes da prensagem e o conjunto foi montado em célula ainda quente, assim que retirado da prensa. 
Dois MEAs comerciais da ETEK de $144 \mathrm{~cm}^{2}$ de área ativa, carga de 0,4:0,4 $\mathrm{mgPt}_{\mathrm{cm}} \mathrm{cm}^{-2}$ e com ELAT nos dois lados do tecido foram utilizados como comparação para os MEAs fabricados por Aspersão e por Impressão à Tela. ELAT é sigla em inglês de um tipo de eletrodo desenvolvido no Los Alamos National Laboratory. Ele é confeccionado à mão e é o estado da arte em camadas de difusão gasosa.

A alimentação de hidrogênio e oxigênio puros ocorreu com vazão de 1,0 L. $\mathrm{min}^{-1}$. As umidificações do ânodo $\left(90^{\circ} \mathrm{C}\right)$ e do cátodo $\left(80^{\circ} \mathrm{C}\right)$ foram implementadas e a temperatura da célula foi mantida entre $65^{\circ} \mathrm{C}$ e $73^{\circ} \mathrm{C}$.

Por fim, foram realizadas comparações de curvas de polarização e de potência e verificada a densidade de corrente a $600 \mathrm{mV}$ e na potência máxima.

\subsection{Custo de Construção da Célula Unitária}

O custo de construção de uma célula unitária de $144 \mathrm{~cm}^{2}$ de área ativa foi levantado. Para este fim, foram mapeados os serviços e os materiais envolvidos na construção de dois conjuntos de células unitárias. Os valores encontrados são aqueles que foram praticados pelos fornecedores contratados pelo IPEN após cotação prévia no mercado. Nenhuma estimativa de custo para a produção em série deste dispositivo foi conduzida por não ser este o alvo da pesquisa. Os valores estão disponíveis em reais.

\subsection{Custo de Produção do MEA por Impressão à Tela}

Uma etapa importante no estabelecimento de um novo método é justamente o custo de produção associado. Neste caso, é importante conhecer o custo dos componentes para fabricação do MEA com $144 \mathrm{~cm}^{2}$ de área ativa e carga de $0,4 \mathrm{mgPt}_{\mathrm{cm}} \mathrm{cm}^{-2} \mathrm{em}$ cada eletrodo, da mão-de-obra empregada e daquele relacionado ao maquinário envolvido. Um dos objetivos do presente trabalho foi $o$ de desenvolver tecnologia para que o parque industrial brasileiro possa aproveitála em atividades comerciais. Como os custos associados à mão-de-obra e à operação e manutenção de equipamentos podem variar em função da localização e do modelo gerencial empregado na indústria, este estudo tem foco no custo dos componentes. Estes são em sua maioria importados e responsáveis pela parcela mais relevante do custo total. De qualquer forma, uma estimativa de tempo de produção (com cinco tamanhos de lotes) e uma simulação com diferentes valores 
de salários de operadores, foram conduzidas para que estudos posteriores possam ser realizados com o objetivo de mensurar os valores não contemplados por este trabalho. $O$ valor de compra da máquina também foi apresentado. Todos os valores foram disponibilizados, neste caso, em dólares americanos (USD). Uma comparação com o método de Aspersão foi conduzida. Foram levados em consideração todos os resultados obtidos nos experimentos predecessores, incluindo o percentual de perda estimada para o novo processo. 


\section{RESULTADOS E DISCUSSÕES}

O processo de confecção de conjuntos eletrodos-membrana (TAB.2) é constituído por diversas etapas. Algumas etapas deste processo foram estudadas para o estabelecimento do novo método de pintura por Impressão à Tela. Além disso, os resultados obtidos são aqui analisados e discutidos para melhor posicionar o método de Impressão à Tela em relação ao já estabelecido processo de pintura por Aspersão e aos interesses do laboratório de células a combustível do tipo PEM do IPEN. Os resultados foram organizados por tópicos relativos a cada característica ou processo que foi investigado e são mostrados a seguir.

\subsection{Tratamento Térmico da Membrana $\left(25 \mathrm{~cm}^{2}\right)$}

O tratamento térmico de membranas para emprego em impressão à tela deve gerar um produto que facilite a determinação da massa inicial e que apresente uma área lisa destinada à pintura, aumentando assim as chances de ocorrer uma boa deposição da pasta catalítica. Na TAB.8 são apresentados os resultados deste experimento.

TABELA 8 - Resultados do Tratamento Térmico $\left(25 \mathrm{~cm}^{2}\right)$

\begin{tabular}{c|cc|cc}
\hline \multirow{2}{*}{ TEMPO (h) } & \multicolumn{2}{|c|}{ MEMBRANA 01 } & \multicolumn{2}{c}{ MEMBRANA 02 } \\
\cline { 2 - 5 } & Massa (g) & \% & Massa (g) & \% \\
\hline 0,0 & 3,3789 & 100 & 3,3345 & 100 \\
\hline 0,5 & 2,1090 & 62,42 & 2,1440 & 64,30 \\
\hline 1,0 & 2,1109 & 62,47 & 2,1374 & 64,10 \\
\hline 2,0 & 2,1090 & 62,42 & 2,1340 & 64,00 \\
\hline
\end{tabular}

Embora não tenha sido quantificada, houve uma redução dimensional das duas membranas submetidas ao tratamento térmico. As membranas apresentaram ainda um leve enrugamento. Na TAB.8 fica evidenciada que, após trinta minutos, a variação da massa da membrana é desprezível. Este fato indica que a massa medida neste tempo pode ser considerada a massa inicial da membrana para o processo de deposição de eletrodo por Impressão à Tela. A importância da determinação de um tempo relativamente curto para o tratamento térmico, não está somente ligada à redução do tempo total de confecção de MEAs, mas principalmente à preservação da membrana, que neste caso deve ser 
preparada sem sofrer danos por exposição a altas temperaturas por um longo período. As membranas resultantes deste experimento ficaram claras e com leve enrugamento. O enrugamento da membrana ganhou foco para ser solucionado em experimentos subseqüentes deste trabalho. Assim, os seguintes parâmetros foram considerados para os tratamentos térmicos posteriores a este experimento: temperatura entre $120^{\circ} \mathrm{C}$ e $125^{\circ} \mathrm{C}$ com duração de trinta minutos e fixação em moldura para manter a membrana lisa. Além disso, nos tratamentos posteriores a redução dimensional da membrana foi levada em consideração a fim de evitar problemas na hora de realizar a pintura.

\subsection{Adição da solução de Nafion $^{\circledR}$ e do Solvente $\left(25 \mathrm{~cm}^{2}\right)$}

O experimento da solução de Nafion $^{\circledR}$ e solvente foi um método qualitativo e de baixo custo com o objetivo de eliminar uma possível composição que gerasse uma pasta catalítica inadequada. Os valores previstos e realizados na preparação das tintas estão dispostos na TAB.9.

TABELA 9 - Resultados da adição da solução de Nafion ${ }^{\circledR}$ e do solvente

\begin{tabular}{|c|c|c|c|c|c|c|c|c|c|c|c|}
\hline \multirow{3}{*}{$\begin{array}{l}\mathrm{T} \\
\mathrm{I} \\
\mathrm{N} \\
\mathrm{T} \\
\mathrm{A}\end{array}$} & \multicolumn{2}{|c|}{ CARBONO } & \multicolumn{5}{|c|}{ SOLUÇÃO DE NAFION ${ }^{\circledR}$} & \multirow{2}{*}{\multicolumn{2}{|c|}{$\begin{array}{c}\text { SOLVENTE } \\
\text { Massa (g) }\end{array}$}} & \multirow{2}{*}{\multicolumn{2}{|c|}{$\begin{array}{c}\mathrm{H}_{2} \mathrm{O} \\
\text { Massa (g) }\end{array}$}} \\
\hline & \multicolumn{2}{|c|}{ Massa (g) } & \multirow[t]{2}{*}{ Tipo } & \multicolumn{2}{|c|}{ Massa (g) } & \multicolumn{2}{|c|}{$\begin{array}{c}\text { Teor } \\
\text { (\% em } \\
\text { massa) }\end{array}$} & & & & \\
\hline & $P$ & $R$ & & $P$ & $R$ & $P$ & $R$ & $P$ & $\boldsymbol{R}$ & $P$ & $R$ \\
\hline T1 & 0,5 & 0,5054 & $5 \%$ & 5,4 & 5,4150 & 35 & 34,88 & 0,0 & 0,0 & 3,0 & 2,9930 \\
\hline T2 & 0,5 & 0,5015 & $10 \%$ & 2,7 & 2,7403 & 35 & 35,33 & 0,0 & 0,0 & 3,0 & 3,0202 \\
\hline T3 & 0,5 & 0,5026 & $5 \%$ & 5,4 & 5,3942 & 35 & 34,92 & 1,5 & 1,5261 & 3,0 & 3,0040 \\
\hline T4 & 0,5 & 0,5021 & $10 \%$ & 2,7 & 2,7572 & 35 & 35,45 & 1,5 & 1,4995 & 3,0 & 3,0012 \\
\hline
\end{tabular}

Os resultados apresentados na TAB.9 demonstram a proximidade entre os valores previstos $(P)$ e realizados $(R)$, esta evidência assegura que o processo de confecção da pasta catalítica possui reprodutibilidade e capacidade em produzir tintas de acordo com a proporção desejada. Neste caso, foi utilizada uma composição de $65 \%$ em massa de eletrocatalisador para $35 \%$ em massa de Nafion ${ }^{\circledR}$ no eletrodo seco. 
Porém, nesta primeira investigação sobre o preparado da pasta catalítica, todas as tintas apresentaram características visualmente similares à amostra da tinta do HIAT. Tal amostra de tinta foi confeccionada com $75 \%$ em massa de catalisador, sendo $20 \%$ em massa Pt e $80 \%$ em massa C, e $25 \%$ em massa de Nafion ${ }^{\circledR}$ considerando o eletrodo seco. Seguiu-se um experimento posterior em célula para verificar o desempenho operacional.

\subsection{Prensagem a quente $\left(25 \mathrm{~cm}^{2}\right)$}

Antes de verificar o desempenho em célula de $25 \mathrm{~cm}^{2}$ de área ativa, foi necessário identificar a adequação do processo de prensagem a quente existente no laboratório. Neste experimento, a seqüência e as características do processo de prensagem a quente realizados no IPEN apresentaram-se adequados, porém a carga aplicada de $246,85 \mathrm{kgf} . \mathrm{cm}^{-2}$ por dois minutos não foi suficiente para fazer aderir o GDL à camada catalítica pintada sobre membrana. Os dois MEAs prensados a $246,85 \mathrm{kgf} . \mathrm{cm}^{-2}$ por dois minutos descolaram. O segundo MEA apresentou uma boa união após ter sido re-prensado três vezes nas mesmas condições anteriores. Como conclusão deve-se utilizar uma carga de $345,59 \mathrm{kgf} . \mathrm{cm}^{-2}$ por dois minutos na prensagem a quente dos MEAs de $25 \mathrm{~cm}^{2}$.

\subsection{Desempenho em Células de $25 \mathrm{~cm}^{2}$}

A recomendação para fixar a membrana em moldura durante o tratamento térmico foi atendida e surtiu excelente efeito. Não houve dificuldade para determinar a massa inicial e nem para esticar as membranas na mesa da máquina. A tinta 52ES com solução de Nafion $^{\circledR} 5 \%$ em massa e adição do solvente 2-[2 Ethoxyethoxy] Ethyl Acetate - 2EEA - foi a que apresentou melhor trabalhabilidade. A pior tinta para se manusear foi a 5SS, com solução de Nafion ${ }^{\circledR}$ $5 \%$ em massa e sem 2EEA. A maior dificuldade de manuseio e deposição da tinta $5 S S$ pode ser atribuída a ausência do 2EEA, já que as duas outras tintas, que possuem o solvente, não apresentaram tantas dificuldades. $O$ efeito do posicionamento de um peso sobre a membrana no processo de secagem sob lâmpada entre as deposições de um mesmo eletrodo foi extremamente benéfico.

As cargas nominais de $\mathrm{Pt}$ foram de $0,4: 0,6 \mathrm{mg} \cdot \mathrm{cm}^{-2}$ no ânodo e no cátodo respectivamente. $\mathrm{Na}$ TAB.10 são apresentadas as cargas calculadas dos MEAs utilizados neste experimento. 
TABELA 10 - Cargas calculadas - Impressão à Tela $\left(25 \mathrm{~cm}^{2}\right)$

\begin{tabular}{|c|c|c|c|c|c|}
\hline \multirow[b]{2}{*}{ TINTA } & \multirow[b]{2}{*}{ MEA } & \multicolumn{2}{|c|}{ Ânodo } & \multicolumn{2}{|c|}{ Cátodo } \\
\hline & & $\begin{array}{c}\mathbf{P t} \\
\left(0,4 \mathrm{mg} \cdot \mathrm{cm}^{-2}\right) \\
\end{array}$ & $\begin{array}{c}\text { Nafion }^{\circledR} \\
(1,08 \text { mg.cm } \\
\text {-2 })\end{array}$ & $\begin{array}{c}\mathbf{P t} \\
\left(0,6 \mathrm{mg} \cdot \mathrm{cm}^{-2}\right) \\
\end{array}$ & $\begin{array}{c}\text { Nafion }^{\circledR} \\
\left(1,62 \mathrm{mg} \cdot \mathrm{cm}^{-2}\right. \\
\end{array}$ \\
\hline \multirow{2}{*}{ 102EA } & Sie25_01 & 0,395 & 1,06 & 0,618 & 1,66 \\
\hline & Sie25_02 & 0,416 & 1,12 & 0,598 & 1,61 \\
\hline \multirow{2}{*}{$52 \mathrm{ES}$} & Sie25_03 & 0,463 & 1,25 & 0,640 & 1,72 \\
\hline & Sie25_04 & 0,489 & 1,32 & 0,640 & 1,72 \\
\hline \multirow{2}{*}{$5 S S$} & Sie25_05 & 0,416 & 1,12 & 0,649 & 1,75 \\
\hline & Sie25_06 & 0,447 & 1,20 & 0,618 & 1,66 \\
\hline
\end{tabular}

Ao confrontar as cargas calculadas com as cargas nominais apresentadas na TAB.10 pode-se verificar que o erro médio para a pintura dos ânodos foi de $9,50 \%$ contra 4,67\% para as cargas do cátodo, sendo que o pico foi de $22 \%$ a mais de carga no ânodo do MEA Sie25_04. Embora o cálculo da carga depositada esteja sujeito a erros em função dos processos de evaporação do solvente da pasta e de secagem da membrana, ele foi realizado para verificar se o desempenho do MEA sofre influência significativa dos desvios entre a carga calculada e a nominal. Os MEAs confeccionados foram comparados (TAB.11) no ponto de potencial de operação (em torno de $600 \mathrm{mV}$ ) de suas melhores curvas.

TABELA 11 - Potencial de Operação - Impressão à Tela $\left(25 \mathrm{~cm}^{2}\right)$

\begin{tabular}{|c|c|c|c|c|c|c|}
\hline \multirow[b]{2}{*}{ PONTO } & \multirow{2}{*}{$\begin{array}{l}\text { MEA } \\
\text { (curva) }\end{array}$} & \multicolumn{5}{|c|}{ RESULTADOS OBTIDOS } \\
\hline & & $\begin{array}{c}\text { I } \\
\text { (A) }\end{array}$ & $\begin{array}{c}\mathbf{i} \\
\left(\mathrm{mA} \cdot \mathrm{cm}^{-2}\right)\end{array}$ & $\begin{array}{c}\mathbf{E} \\
(\mathrm{mV})\end{array}$ & $\begin{array}{l}P \\
(W)\end{array}$ & $\begin{array}{c}\mathbf{p} \\
\left(\mathrm{mW} . \mathrm{cm}^{-2}\right)\end{array}$ \\
\hline \multirow{6}{*}{$E_{\text {ope }}$} & Sie25_01c & 17,0 & 680 & 598 & 10,17 & 406,64 \\
\hline & Sie25_02c & 18,0 & 720 & 599 & 10,78 & 431,28 \\
\hline & Sie25_03c & 16,0 & 640 & 600 & 9,60 & 384,00 \\
\hline & Sie25_04c & 19,0 & 760 & 605 & 11,50 & 459,80 \\
\hline & Sie25_05b & 16,0 & 640 & 602 & 9,63 & 385,28 \\
\hline & Sie25_06a & 17,0 & 680 & 605 & 10,27 & 410,72 \\
\hline
\end{tabular}

Todos os conjuntos testados apresentaram altas densidades de corrente, acima de $600 \mathrm{~mA} \cdot \mathrm{cm}^{-2}$ no potencial de operação, $600 \mathrm{mV}$. Este fato comprova que o processo de Impressão à Tela é capaz de produzir MEAs de alto 
desempenho, um dos objetivos deste trabalho. O maior valor de densidade de corrente a $600 \mathrm{mV}$ foi de $760 \mathrm{~mA} . \mathrm{cm}^{-2}$ para a curva "c" do MEA Sie25_04 pintado com a tinta $52 E S$ - solução de Nafion $^{\circledR} 5 \%$ em massa e 2EEA. Embora este MEA tenha alcançado o melhor resultado, na TAB.11 é relacionado o MEA Sie25_03, confeccionado com a mesma tinta, que obteve o pior resultado, $640 \mathrm{~mA} . \mathrm{cm}^{-2} \mathrm{a}$ $600 \mathrm{mV}$. Isto significa que houve falha no processo de confecção. Desta maneira, o processo de deposição do eletrodo pode não possuir boa reprodutibilidade ou o processo de prensagem a quente não confere aderência adequada entre as camadas, difusora e catalítica. A análise das curvas de polarização dos MEAs confeccionados pode ajudar na identificação da falha. Caso haja comportamento discrepante na região de polarização por ativação, região de maior influência da camada catalítica, em MEAs confeccionados com a mesma tinta, a probabilidade de falha será maior no processo de Impressão à Tela, principalmente se as regiões predominantemente lineares das curvas dos dois MEAs estiverem paralelas. Porém, se o comportamento na região de ativação for similar e os coeficientes angulares das regiões lineares forem diferentes, a probabilidade de falha será maior no processo de Prensagem a Quente, já que este é o responsável por estabelecer o contato entre as duas camadas, difusora e catalítica, e assim viabilizar o transporte eletrônico até o circuito externo.

As Curvas de Polarização dos MEAs de $25 \mathrm{~cm}^{2}$ pintados por Impressão à Tela foram realizadas em operação com $\mathrm{H}_{2} / \mathrm{O}_{2}$ puros. Somente o ânodo foi umidificado a $85^{\circ} \mathrm{C}$. Vazões foram mantidas com o dobro da estequiometria e a temperatura de célula mantida a $70^{\circ} \mathrm{C}$. Cada tinta foi utilizada em dois MEAs. Cada MEA foi ativado e posteriormente foram realizadas de três a quatro curvas por conjunto ativado. O tempo médio de ativação foi de três dias (oito horas cada dia) para todos os conjuntos testados.

As melhores curvas dos dois MEAs confeccionados com a tinta 102EA - solução de Nafion ${ }^{\circledR} 10 \%$ em massa, 2EEA e $\mathrm{H}_{2} \mathrm{O}$ ultrapura - são apresentadas na FIG.9. 


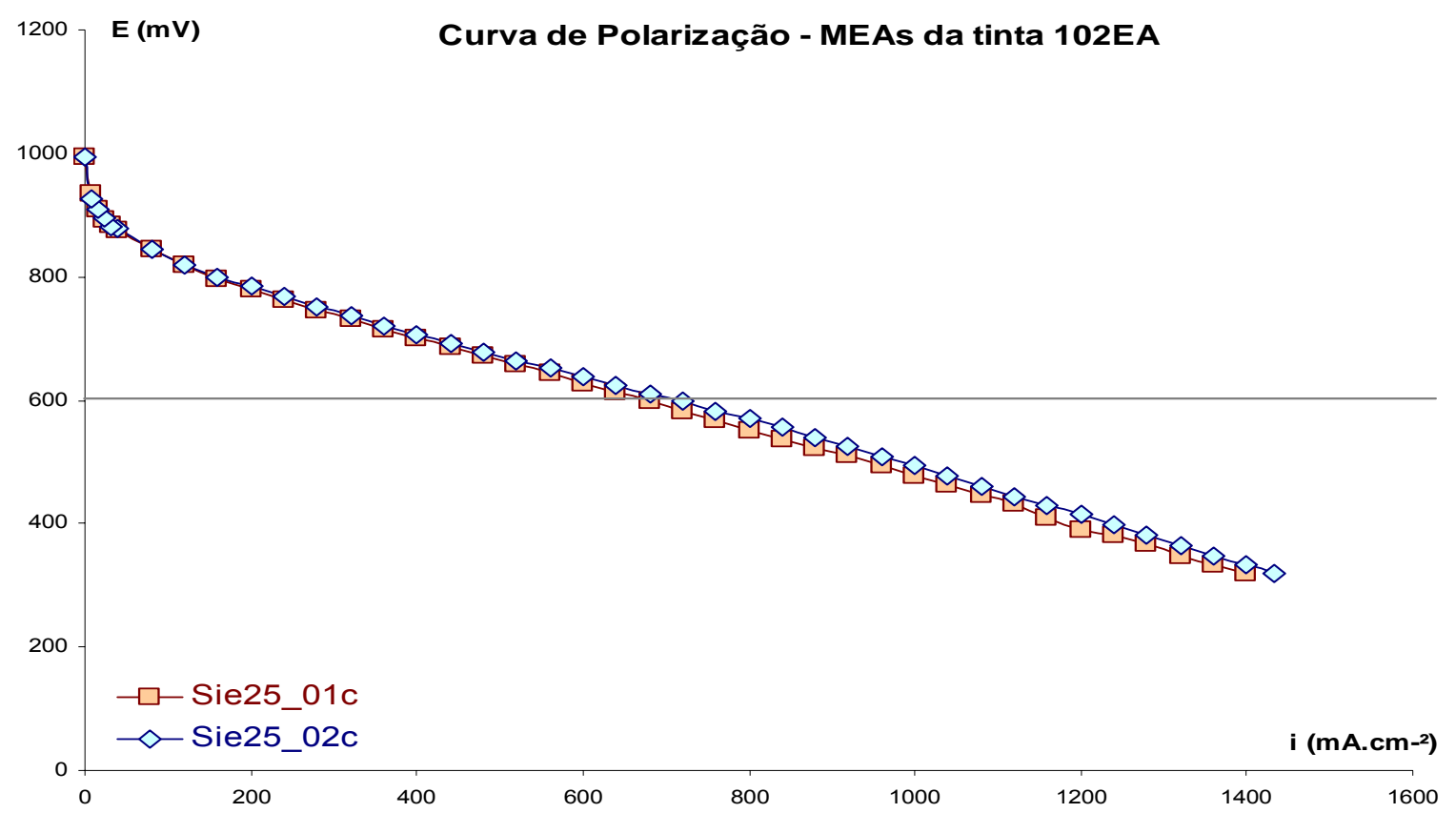

FIGURA 9 - Curvas de Polarização dos MEAs $\left(25 \mathrm{~cm}^{2}\right)$ pintados por Impressão à Tela com a tinta 102EA (solução de Nafion $^{\circledR} 10 \%$ em massa, 2EEA e $\mathrm{H}_{2} \mathrm{O}$ ultrapura). Operação com $\mathrm{H}_{2} / \mathrm{O}_{2}$ puros. Umidificação somente no ânodo $\left(85^{\circ} \mathrm{C}\right)$. Vazões com o dobro da estequiometria. Temperatura de célula mantida a $70^{\circ} \mathrm{C}$.

As duas curvas apresentam comportamentos similares tanto na região de polarização por ativação como na região de polarização por queda ôhmica. O MEA Sie25_01 obteve resultado de $680 \mathrm{~mA} \cdot \mathrm{cm}^{-2}$ ou $17 \mathrm{~A}$ a $600 \mathrm{mV}$ e o conjunto Sie25_02 alcançou $720 \mathrm{~mA} . \mathrm{cm}^{-2}$ ou 18 A neste mesmo potencial, uma variação menor do que $6 \%$. Na região de transição entre predominância de polarização por ativação e predominância de polarização por queda ôhmica, ou seja, em torno de $800 \mathrm{mV}$, as densidades de corrente para Sie25_01c e para Sie25_02c foram iguais a $160 \mathrm{~mA} \cdot \mathrm{cm}^{-2}$. Na região linear do gráfico, as resistências encontradas foram de $373 \mathrm{~m} \Omega . \mathrm{cm}^{2}$ para Sie25_01c e $356 \mathrm{~m} \Omega . \mathrm{cm}^{2}$ para Sie25_02c. A reprodutibilidade do processo de confecção de MEAs utilizando a tinta 102EA foi boa porque demonstrou que o comportamento das melhores curvas, da prova e contra-prova, é similar tanto em $600 \mathrm{mV}$ como em toda a extensão das curvas de polarização. Porém é necessário comparar estas curvas com aquelas obtidas pelos MEAs confeccionados com as demais tintas.

As demais tintas, 52ES e 5SS, utilizaram a solução de Nafion ${ }^{\circledR} 5 \%$ em massa. De acordo com os valores apresentados na TAB.11 os conjuntos confeccionados com a tinta 52ES obtiveram comportamentos diferentes entre 
prova e contraprova em torno de $600 \mathrm{mV}$. As melhores curvas dos dois MEAs confeccionados com a tinta $52 E S$ - solução de Nafion ${ }^{\circledR} 5 \%$ em massa e 2EEA são apresentadas na FIG.10.

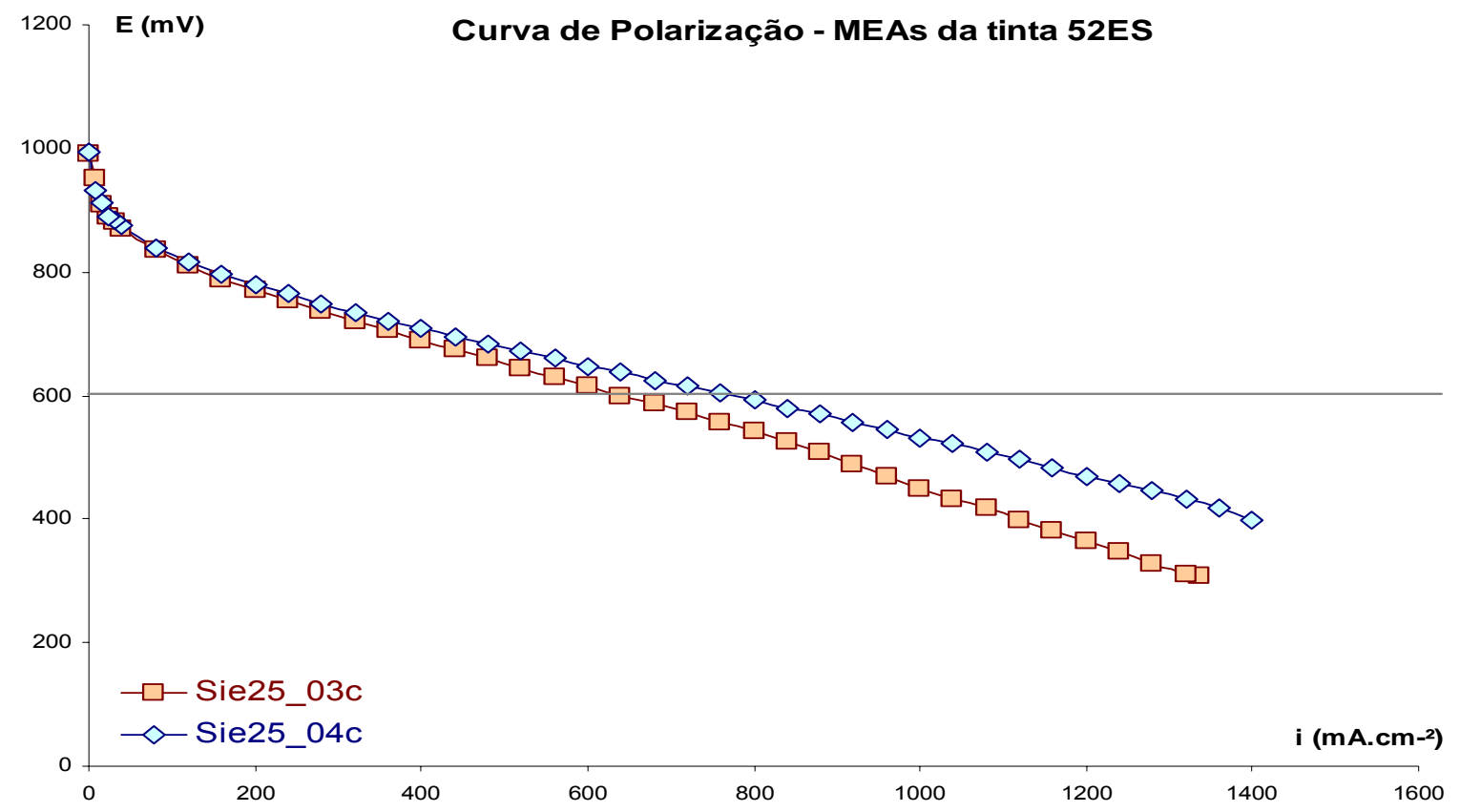

FIGURA 10- Curvas de Polarização dos MEAs $\left(25 \mathrm{~cm}^{2}\right)$ pintados por Impressão à Tela com a tinta 52ES (solução de Nafion ${ }^{\circledR} 5 \%$ em massa e 2EEA). Operação com $\mathrm{H}_{2} / \mathrm{O}_{2}$ puros. Umidificação somente no ânodo $\left(85^{\circ} \mathrm{C}\right)$. Vazões com o dobro da estequiometria. Temperatura de célula mantida a $70^{\circ} \mathrm{C}$.

Na FIG.10 é percebida uma grande diferença de comportamento das curvas na região de polarização por queda ôhmica. Na região de polarização por ativação, as curvas Sie25_03c e Sie25_04c apresentam comportamentos idênticos. A variação percentual ultrapassa $18 \%$ em torno de $600 \mathrm{mV}$, com Sie25_03c apresentando $640 \mathrm{~mA} . \mathrm{cm}^{-2}$ ou 16 A e Sie25_04c alcançando o valor máximo de todo o experimento neste potencial, $760 \mathrm{~mA} \cdot \mathrm{cm}^{-2}$ ou $19 \mathrm{~A}$. Na região de transição entre predominância de polarização por ativação e predominância de polarização por queda ôhmica os resultados foram de $80 \mathrm{~mA} \cdot \mathrm{cm}^{-2}$ a $840 \mathrm{mV}$ para os MEAs Sie25_03c e Sie25_04c. As resistências obtidas a partir dos coeficientes angulares da região linear das curvas de polarização dos conjuntos foram de $378 \mathrm{~m} \Omega . \mathrm{cm}^{2}$ para Sie25_03c e $302 \mathrm{~m} \Omega . \mathrm{cm}^{2}$ para Sie25_04c. O comportamento similar na região de polarização por ativação e discrepante na região linear das curvas Sie25_03c e Sie25_04c indica, portanto, uma possível falha na prensagem a quente do conjunto Sie25_03. 
Na FIG.11 são apresentadas as melhores curvas da tinta 5SS - solução de Nafion ${ }^{\circledR} 5 \%$ em massa sem 2 EEA.

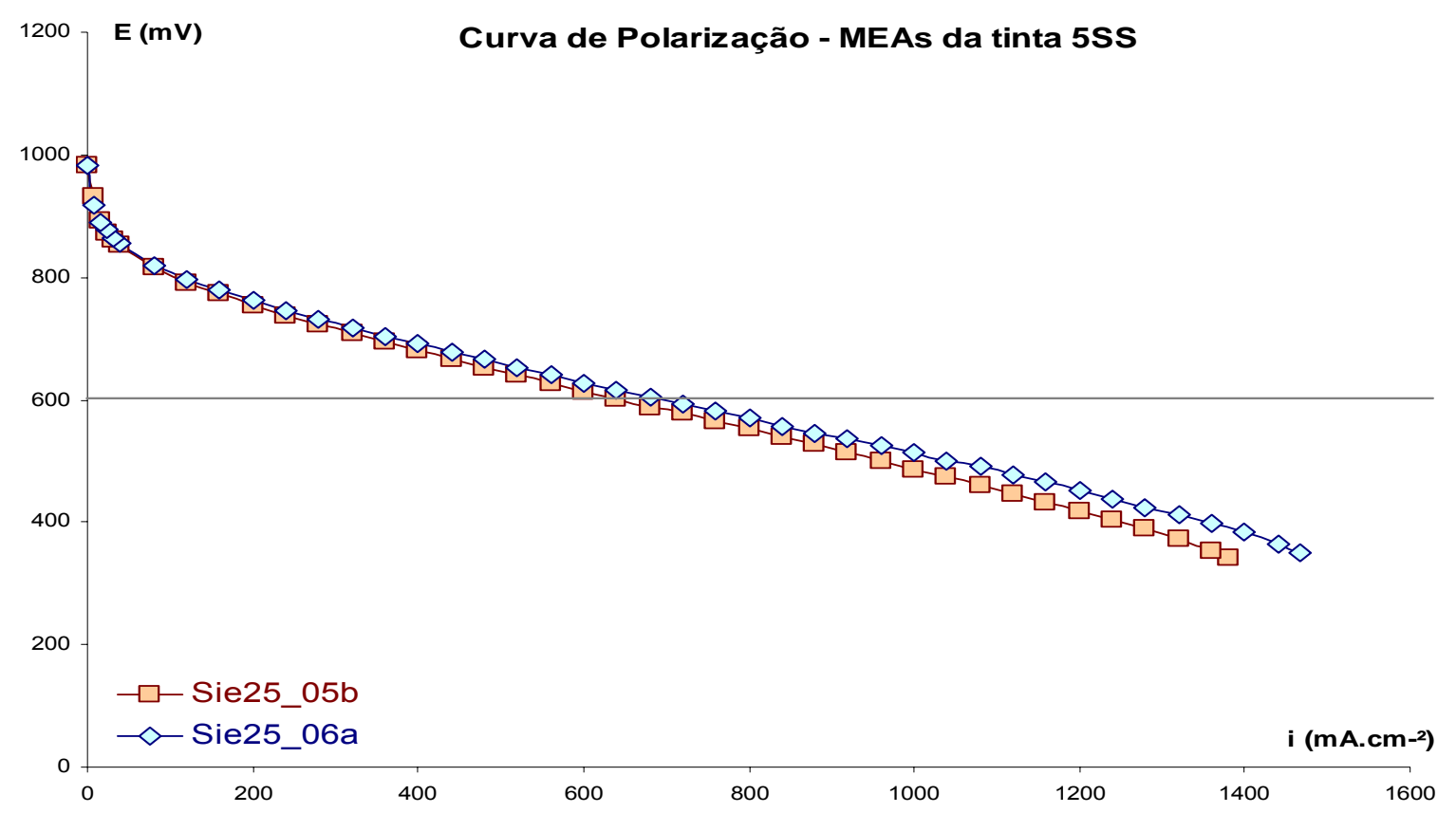

FIGURA 11- Curvas de Polarização dos MEAs $\left(25 \mathrm{~cm}^{2}\right)$ pintados por Impressão à Tela com a tinta 5 SS (solução de Nafion $^{\circledR} 5 \%$ em massa sem 2EEA). Operação com $\mathrm{H}_{2} / \mathrm{O}_{2}$ puros. Umidificação somente no ânodo $\left(85^{\circ} \mathrm{C}\right)$. Vazões com o dobro da estequiometria. Temperatura de célula mantida a $70^{\circ} \mathrm{C}$.

É observado um comportamento similar entre as curvas Sie25_05b e Sie25_06a apresentadas na FIG.11. Em torno de 600 mV, Sie25_05b alcançou 640 mA.cm ${ }^{-2}$ e Sie25_06a obteve 680 mA.cm ${ }^{-2}$ (diferença abaixo de 6,3\%). No potencial em torno de $800 \mathrm{mV}$ as densidades de corrente encontradas foram de $120 \mathrm{~mA} . \mathrm{cm}^{-2}$ para os dois conjuntos. Para os mesmos MEAs, à $840 \mathrm{mV}$ foram obtidas densidades de corrente de $40 \mathrm{~mA} \cdot \mathrm{cm}^{-2}$. Sie25_05b apresentou resistência maior, $331 \mathrm{~m} \Omega . \mathrm{cm}^{2}$, enquanto $304 \mathrm{~m} \Omega . \mathrm{cm}^{2}$ foi encontrado para Sie25_06a. A reprodutibilidade do processo de confecção de MEAs utilizando a tinta 5SS foi boa porque demonstrou que o comportamento das melhores curvas, da prova e contraprova, é similar. Um pequeno descolamento entre as curvas é observado a altas densidades de corrente em função da maior resistência do conjunto Sie25_05, provavelmente, causada por falha no processo de prensagem a quente ou por degradação da membrana ao longo das etapas de confecção do MEA.

As melhores curvas de cada tinta são confrontadas na FIG.12. 


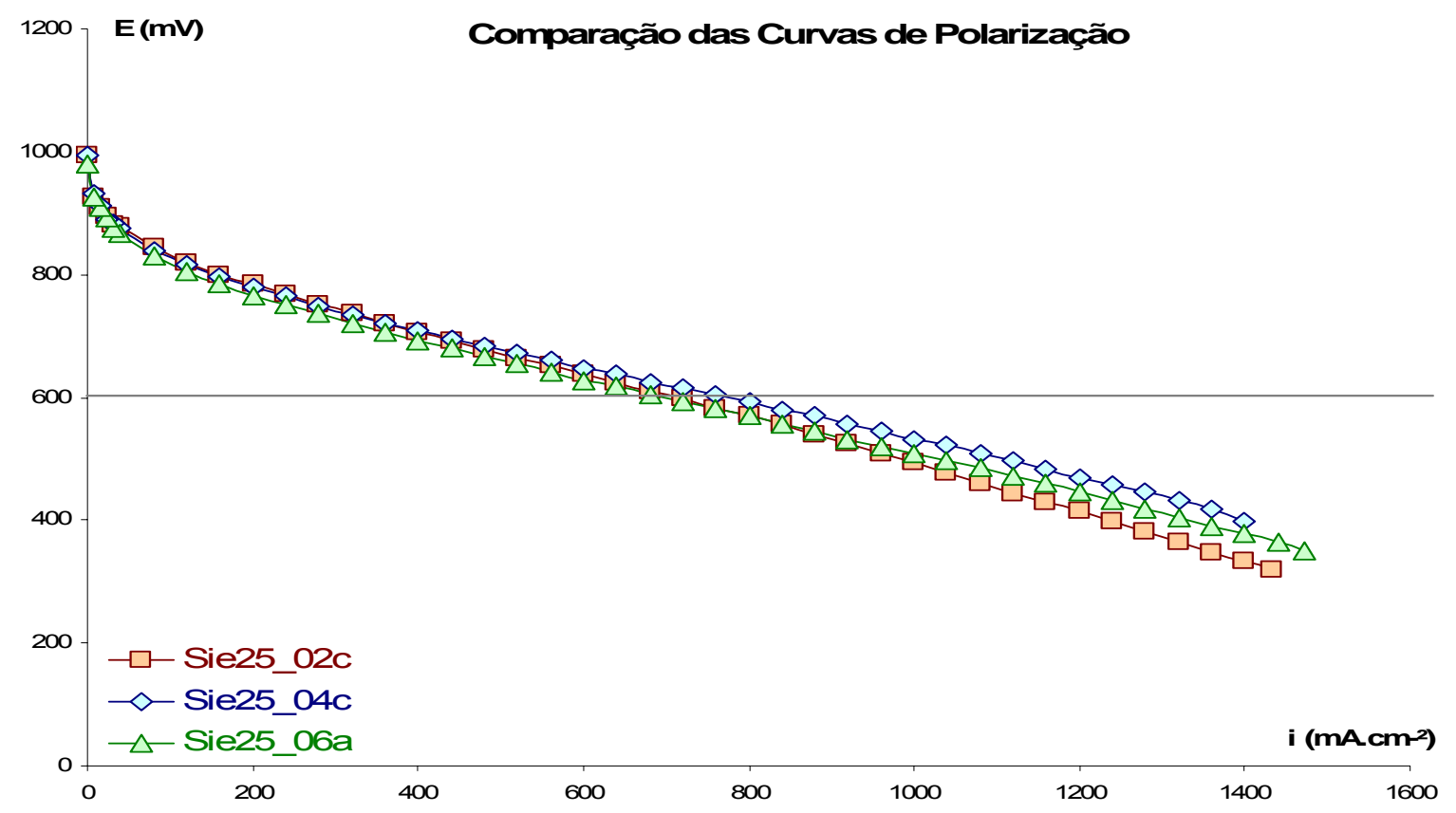

FIGURA 12- Curvas de Polarização dos melhores MEAs $\left(25 \mathrm{~cm}^{2}\right)$ de cada tinta (Sie25_02c, Sie25_04c e Sie25_06a) pintados por Impressão à Tela. Operação com $\mathrm{H}_{2} / \mathrm{O}_{2}$ puros. Umidificação somente no ânodo $\left(85^{\circ} \mathrm{C}\right)$. Vazões com o dobro da estequiometria. Temperatura de célula mantida a $70^{\circ} \mathrm{C}$.

Na FIG.12 são apresentadas as curvas de polarização dos melhores MEAs de cada tinta. Percebe-se que, os conjuntos Sie25_04 e Sie25_06 apresentam resistências similares, em torno de $300 \mathrm{~m} \Omega . \mathrm{cm}^{2}$. Comportamento esperado uma vez que foi utilizada a mesma membrana comercial para todos os conjuntos. Porém, a curva Sie25_02c demonstrou maior resistência, $356 \mathrm{m \Omega} . \mathrm{cm}^{2}$, o que significa que algum parâmetro relacionado à condutividade pode ter variado dentre todo o processo de confecção dos MEAs.

A suspeita sobre, falhas no processo de prensagem a quente ou de degradação da membrana ao longo das etapas de confecção do MEA, é pertinente, uma vez que qualquer uma destas ocorrências é capaz de aumentar a resistência do conjunto. Estas hipóteses também justificariam a diferença de comportamento entre as curvas Sie25_3c e Sie25_4c apresentadas na FIG.10, de MEAs pintados com a mesma tinta. Tais curvas apresentam uma diferença máxima de $40 \mathrm{~mA} \cdot \mathrm{cm}^{-2}$ para um mesmo potencial na região de transição em torno de $800 \mathrm{mV}$ e por outro lado chegam a apresentar uma diferença de $280 \mathrm{~mA} . \mathrm{cm}^{-2}$ na região de queda ôhmica em torno de $400 \mathrm{mV}$. Esta observação leva a conclusão de que a deposição do eletrodo foi similar nos dois MEAs e as 
barreiras existentes para a troca de carga apresentam valores muito próximos, porém reforça as hipóteses de falhas no processo de prensagem e de degradação da membrana ao longo das etapas de confecção do MEA.

Analisando os resultados obtidos na transição entre a região de ativação e queda ôhmica, o comportamento das curvas Sie25_02c e Sie25_04c apresentadas na FIG.12 é semelhante, alcançando valor igual a $160 \mathrm{~mA} . \mathrm{cm}^{-2} \mathrm{em}$ torno de $800 \mathrm{mV}$, enquanto Sie25_06a obteve neste mesmo potencial a densidade de corrente de $120 \mathrm{~mA} \cdot \mathrm{cm}^{-2}$, variação de $40 \mathrm{~mA} \cdot \mathrm{cm}^{-2}$ na comparação com as outras duas curvas. Este comportamento indica que o processo de Impressão à Tela, embora tenha demonstrado excelente reprodutibilidade, provavelmente, apresentou maior dificuldade para a deposição do eletrodo utilizando a tinta $5 S S$ - solução de Nafion ${ }^{\circledR} 5 \%$ em massa sem $2 E E A$ - em função da pior trabalhabilidade desta.

Os MEAs confeccionados também foram comparados (TAB.12) nos pontos de potência máxima de suas melhores curvas.

TABELA 12 - Potência Máxima - Impressão à Tela $\left(25 \mathrm{~cm}^{2}\right)$

\begin{tabular}{|c|c|c|c|c|c|c|}
\hline \multirow[b]{2}{*}{ PONTO } & \multirow{2}{*}{$\begin{array}{c}\text { MEA } \\
\text { (curva) }\end{array}$} & \multicolumn{5}{|c|}{ RESULTADOS OBTIDOS } \\
\hline & & $\begin{array}{c}\text { I } \\
\text { (A) }\end{array}$ & $\begin{array}{c}\text { i } \\
\left(\mathrm{mA} \cdot \mathrm{cm}^{-2}\right)\end{array}$ & $\begin{array}{c}E \\
(\mathrm{mV})\end{array}$ & $\begin{array}{c}P \\
(W)\end{array}$ & $\begin{array}{c}\text { p } \\
\left(\mathrm{mW} \cdot \mathrm{cm}^{-2}\right)\end{array}$ \\
\hline \multirow{6}{*}{$P_{\text {máx }}$} & Sie25_01c & 27,0 & 1.080 & 447 & 12,07 & 482,76 \\
\hline & Sie25_02c & 29,0 & 1.160 & 429 & 12,44 & 497,64 \\
\hline & Sie25_03c & 24,0 & 960 & 470 & 11,28 & 451,20 \\
\hline & Sie25_04c & 33,0 & 1.320 & 432 & 14,26 & 570,24 \\
\hline & Sie25_05b & 29,0 & 1.160 & 432 & 12,53 & 501,12 \\
\hline & Sie25_06a & 31,0 & 1.240 & 439 & 13,61 & 544,36 \\
\hline
\end{tabular}

$\mathrm{Na}$ TAB.12 são apresentados os picos de potência de todos os conjuntos utilizados neste experimento. Os maiores valores de potência foram observados em um intervalo de potencial entre $429 \mathrm{mV}$ e $470 \mathrm{mV}$, sendo o melhor resultado alcançado pelo conjunto Sie25_04 com 14,26 W a $33 \mathrm{~A}$.

Embora, observado na TAB.11 que os conjuntos Sie25_01 e Sie25_02, pintados com a tinta 102EA - solução de Nafion ${ }^{\circledR} 10 \%$ em massa, 2 EEA e $\mathrm{H}_{2} \mathrm{O}$ ultrapura, apresentaram melhor, ou no mínimo igual, desempenho a $600 \mathrm{mV}$ do que os MEAs Sie25_05 e Sie25_06, confeccionados com a tinta 5SS - solução de 
Nafion ${ }^{\circledR} 5 \%$ em massa sem 2EEA, os resultados apresentados na TAB.12 demonstram comportamento inverso no pico de potência. Os MEAs Sie25_01 e Sie25_02 apresentaram densidade de potência máxima inferior a $500 \mathrm{~mW} . \mathrm{cm}^{-2}$, enquanto os conjuntos Sie25_05 e Sie25_06 obtiveram valores maiores do que os $500 \mathrm{~mW} . \mathrm{cm}^{-2}$. Estes resultados demonstram o impacto da resistência na potência da célula a combustível com a evolução da densidade de corrente.

As melhores curvas de potência de cada tinta são confrontadas na FIG.13.

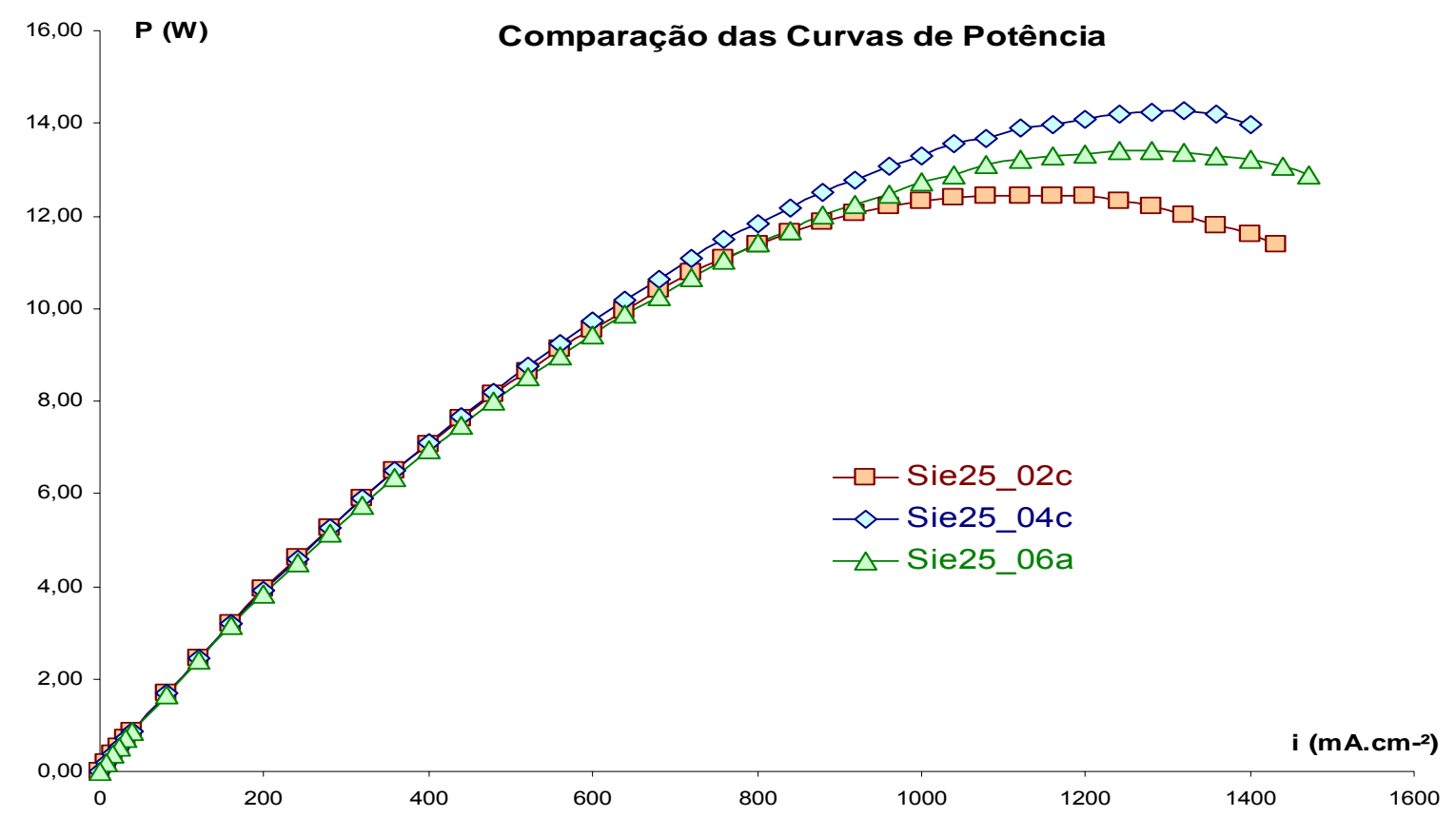

FIGURA 13- Curvas de Potência dos melhores MEAs $\left(25 \mathrm{~cm}^{2}\right)$ de cada tinta (Sie25_02c, Sie25_04c e Sie25_06a) pintados por Impressão à Tela. Ōperação com $\mathrm{H}_{2} / \mathrm{O}_{2}$ puros. Umidificação somente no ânodo $\left(85^{\circ} \mathrm{C}\right)$. Vazões com o dobro da estequiometria. Temperatura de célula mantida a $70^{\circ} \mathrm{C}$.

Fica evidenciada na FIG.13 a queda de potência da curva Sie25_02c e que a partir de $20 \mathrm{~A}\left(800 \mathrm{~mA} . \mathrm{cm}^{-2}\right)$ o conjunto Sie25_06 começa a apresentar melhor desempenho. Em comparação aos demais, o conjunto Sie25_04 apresentou os melhores resultados ao longo de toda a curva de potência. Uma boa deposição do eletrodo e uma boa prensagem a quente foram os principais responsáveis por este desempenho. Na FIG.14 são plotadas as curvas de polarização e de potência para o MEA Sie25_04, que apresentou o melhor desempenho neste experimento. 


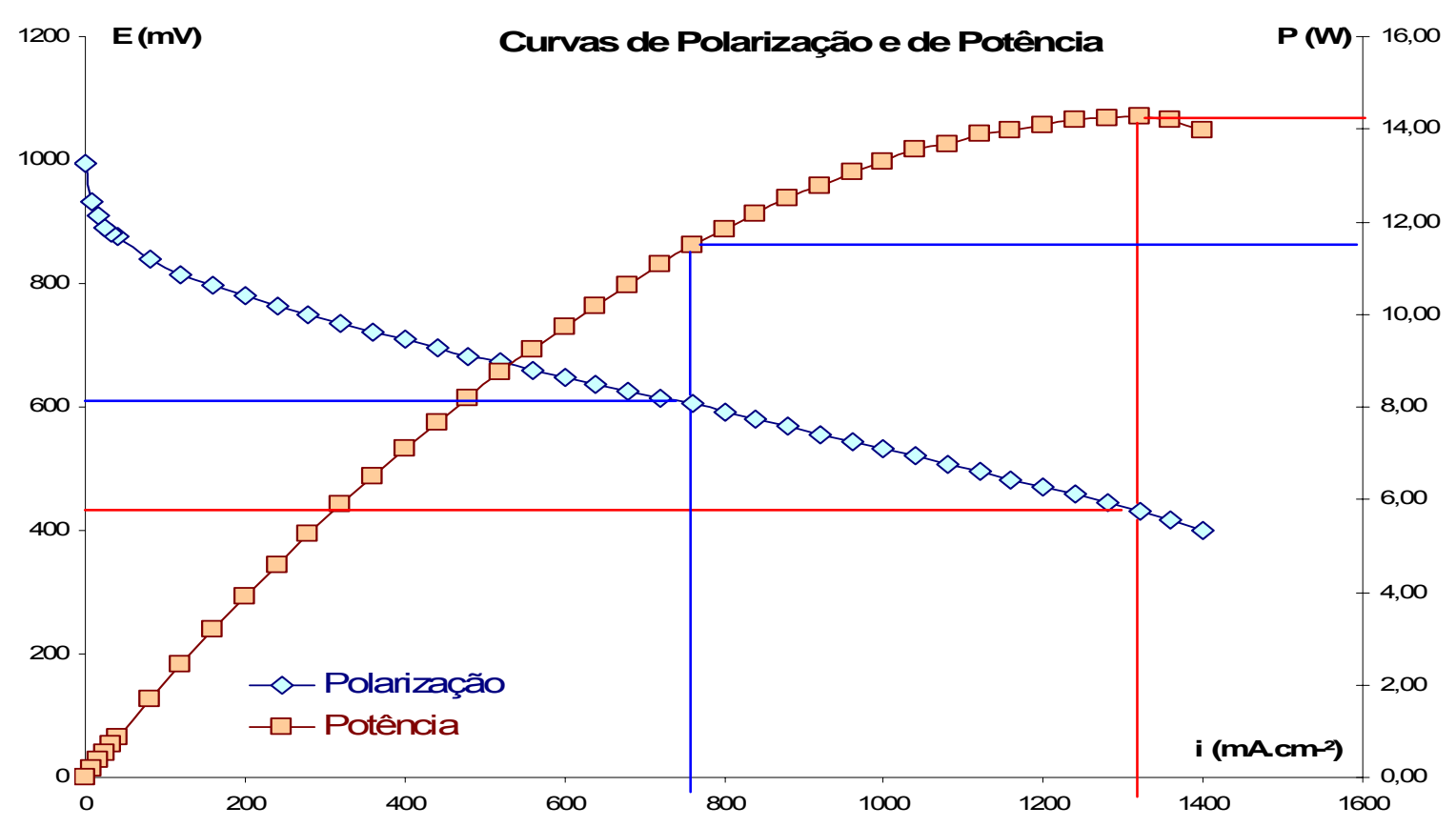

FIGURA 14- Curva de Polarização e de Potência do melhor MEA $\left(25 \mathrm{~cm}^{2}\right)$ (Sie25_04c) pintado por Impressão à Tela. Operação com $\mathrm{H}_{2} / \mathrm{O}_{2}$ puros. Umidificação somente no ânodo $\left(85^{\circ} \mathrm{C}\right)$. Vazões com o dobro da estequiometria. Temperatura de célula mantida a $70^{\circ} \mathrm{C}$.

As linhas verticais e horizontais, em azul, na FIG.14 simbolizam uma operação a $605 \mathrm{mV}$ com $760 \mathrm{~mA} . \mathrm{cm}^{-2}$ e $11,5 \mathrm{~W}\left(460 \mathrm{~mW} \cdot \mathrm{cm}^{-2}\right)$. A operação no pico de potência, a $432 \mathrm{mV}$ com $1320 \mathrm{~mA} \cdot \mathrm{cm}^{-2}$ e $14,26 \mathrm{~W}\left(570 \mathrm{~mW} \cdot \mathrm{cm}^{-2}\right)$, é representada pelas linhas vermelhas horizontais e verticais. As duas operações simbolizadas na FIG.14 evidenciam os melhores resultados obtidos para o potencial de operação e para a potência máxima.

De maneira geral, o processo de Impressão à Tela conseguiu reproduzir os resultados, uma vez que os dois conjuntos, prova e contra-prova, de uma mesma tinta apresentaram comportamentos similares na região de polarização por ativação. Um menor desempenho, a $600 \mathrm{mV}$, foi observado para os conjuntos confeccionados com a tinta $5 S S$ - solução de Nafion ${ }^{\circledR} 5 \%$ em massa sem 2EEA - nesta região, acarretado pela possível maior dificuldade de deposição demonstrada por esta tinta. Para cada tinta, os MEAs confeccionados apresentaram comportamentos similares na região linear das curvas de polarização com variação de 1,0 A no potencial de operação dos MEAs. Exceção foi verificada para a tinta $52 \mathrm{ES}$ com solução de Nafion $^{\circledR} 5 \%$ em massa e com 2EEA que mostrou uma diferença de 3,0 $\mathrm{A}$ a $600 \mathrm{mV}$ entre as melhores curvas dos dois conjuntos que a utilizaram. Esta diferença foi causada, provavelmente, 
por falha no processo de prensagem a quente ou por degradação da membrana. $O$ processo de prensagem a quente foi acompanhado em experimentos posteriores para se verificar a hipótese levantada. O MEA Sie25_02c foi o conjunto que apresentou a menor carga de $\mathrm{Pt}$ e Nafion ${ }^{\circledR}$ no cátodo e a segunda menor carga no ânodo (TAB.10), porém apresentou o segundo melhor desempenho a $600 \mathrm{mV}$ (TAB.11), o que comprova que a variação de carga não gerou influência significativa no desempenho da célula.

\subsection{MEV 25 cm² $^{2}$ Impressão à Tela vs Aspersão}

Na FIG.15 são apresentadas imagens da superfície de áreas ativas de MEAs confeccionados por Aspersão e por Impressão à Tela.

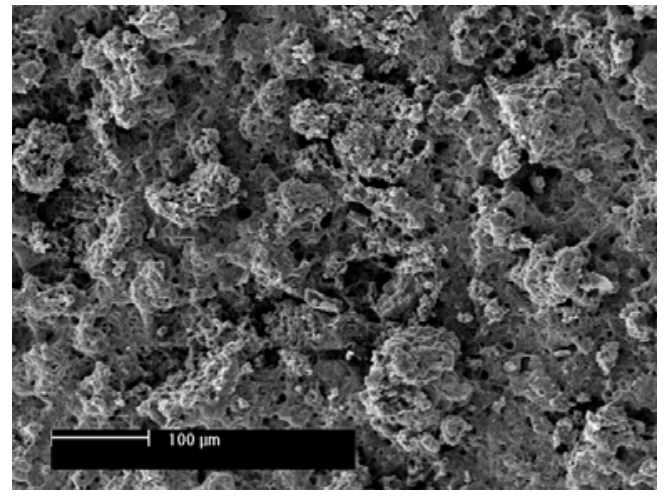

(a)

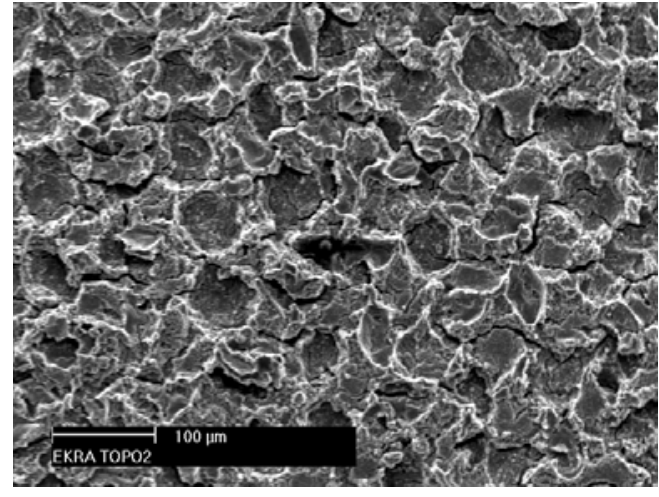

(b)

FIGURA 15 - MEV da superfície dos MEAs (sem prensagem): (a) Aspersão; (b) Impressão à Tela.

Na comparação entre os processos de Aspersão e Impressão à Tela por Microscopia Eletrônica de Varredura, FIG.15, observou-se uma camada mais coesa e homogênea na imagem do conjunto impresso pelo último método. Este aspecto da camada catalítica depositada por Impressão à Tela indica que, provavelmente, o eletrodo foi construído sem gerar áreas preferenciais, evitando assim a concentração da formação da tripla fase reacional em pontos isolados do eletrodo. Por outro lado, a camada confeccionada por Aspersão apresenta características que podem privilegiar a formação de tais áreas preferenciais. Através da análise das imagens da seção transversal poderemos comparar mais facilmente os diferentes métodos de deposição de eletrodo em relação a adesão da camada catalítica à membrana. Na FIG.16 são apresentadas as micrografias da seção transversal desses MEAs. 


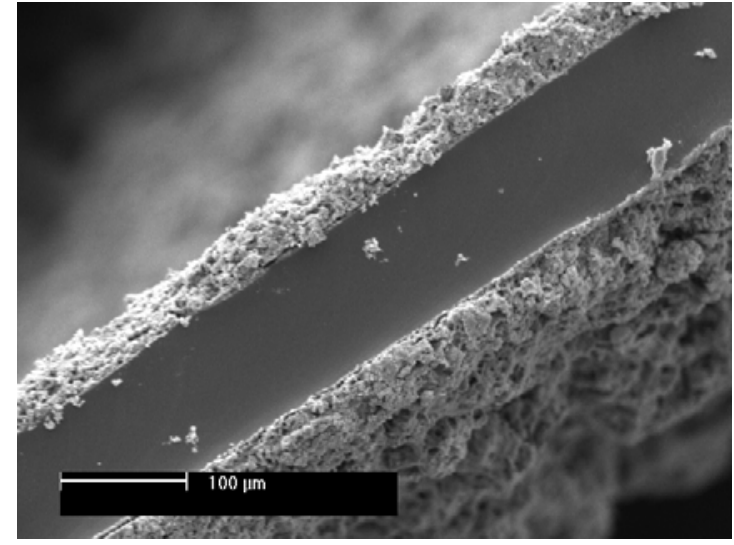

(a)

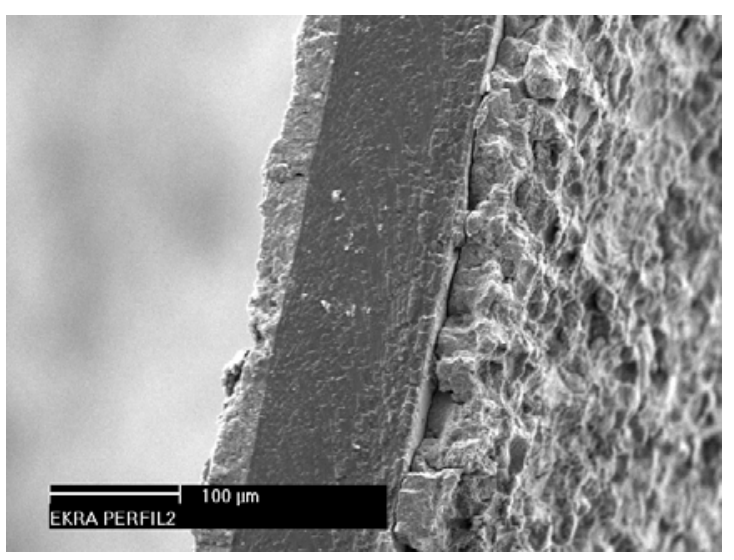

(b)

FIGURA 16 - MEV da seção transversal dos MEAs (sem prensagem): (a) Aspersão; (b) Impressão à Tela.

A adesão da camada catalítica à membrana foi similar para os dois processos de pintura. Não há sinais de falhas superficiais na cobertura das membranas (FIG.15) e as imagens da FIG.16 não apresentam evidências de dificuldades de adesão na seção transversal dos dois conjuntos. Porém, a formação final dos conjuntos conta com a adesão do GDL à camada catalítica e para verificar a real interferência do processo de deposição do eletrodo no comportamento físico da camada catalítica foi realizada nova comparação de micrografias, desta vez após prensagem. Dois MEAs, um de cada processo, foram prensados e posteriormente tiveram o GDL descolado para que se pudesse analisar a conformação da camada catalítica após a atividade de prensagem a quente. Estas micrografias são apresentadas na FIG.17.

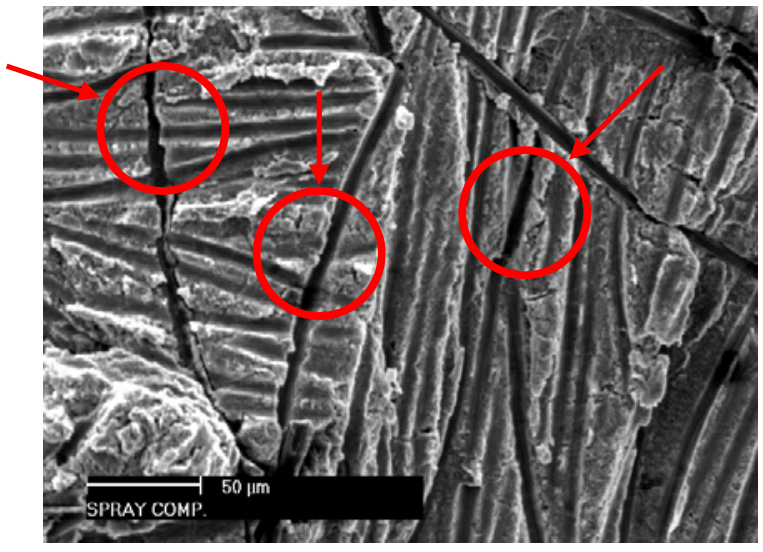

(a)

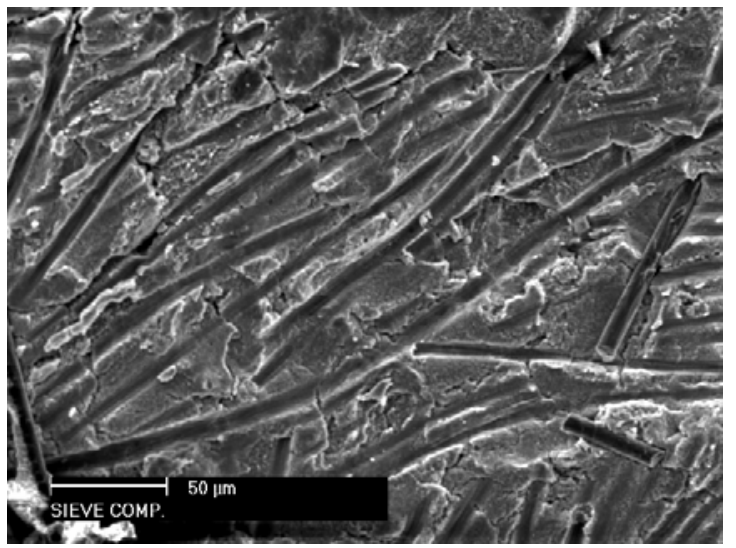

(b)

FIGURA 17 - MEV dos MEAs com GDLs descolados: (a) Aspersão; (b) Impressão à Tela. 
Como indicado pelas setas na FIG.17, a imagem da coluna (a), relativa ao processo de Aspersão, sugere que esta camada catalítica sofreu maior deformação que aquela apresentada na coluna (b), porque os sulcos dos fios do tecido de carbono aparentam estar mais profundos. Tais imagens estão coerentes com as micrografias da FIG.15, onde o eletrodo confeccionado por Impressão à Tela se mostrou muito mais compacto o que, possivelmente, resultou em maior resistência à deformação durante o processo de prensagem.

Estes resultados mostraram que, provavelmente, diferentes parâmetros de prensagem a quente serão necessários para gerar boa adesão entre GDL e camada catalítica para os eletrodos depositados pelos diferentes métodos construtivos estudados neste trabalho, Impressão à Tela e Aspersão.

\subsection{Curva de Polarização $25 \mathrm{~cm}^{2}$ - Impressão à Tela vs Aspersão}

O segundo método de comparação dos processos de Impressão à Tela e de Aspersão foi realizado através de operação de células unitárias. As condições de operação das células a combustível foram mantidas constantes. Os MEAs confeccionados por Aspersão foram comparados (TAB.13) no ponto de potencial de operação (em torno de $600 \mathrm{mV}$ ) de suas melhores curvas.

TABELA 13 - Potencial de Operação - Aspersão $\left(25 \mathrm{~cm}^{2}\right)$

\begin{tabular}{|c|c|c|c|c|c|c|}
\hline \multirow[b]{2}{*}{ PONTO } & \multirow{2}{*}{$\begin{array}{c}\text { MEA } \\
\text { (curva) }\end{array}$} & \multicolumn{5}{|c|}{ RESULTADOS OBTIDOS } \\
\hline & & $\begin{array}{c}\text { I } \\
(\mathrm{A})\end{array}$ & $\begin{array}{c}i \\
\left(\mathrm{~mA} . \mathrm{cm}^{-2}\right)\end{array}$ & $\begin{array}{c}E \\
(\mathrm{mV})\end{array}$ & $\begin{array}{c}P \\
(W)\end{array}$ & $\begin{array}{c}\mathbf{p} \\
\left(\mathrm{mW} \cdot \mathrm{cm}^{-2}\right)\end{array}$ \\
\hline \multirow{5}{*}{$E_{\text {ope }}$} & Spr25_01d & 13,0 & 520 & 604 & 7,85 & 314,08 \\
\hline & Spr25_02c & 14,0 & 560 & 598 & 8,37 & 334,88 \\
\hline & Spr25_03d & 18,0 & 720 & 600 & 10,80 & 432,00 \\
\hline & Spr25_04b & 17,0 & 680 & 596 & 10,13 & 405,28 \\
\hline & Sie25_04c & 19,0 & 760 & 605 & 11,50 & 459,80 \\
\hline
\end{tabular}

Todos os MEAs estudados apresentaram um tempo médio de ativação de vinte e quatro horas (oito horas por dia). O MEA Spr25_03, conforme TAB.13, apresentou em sua curva "d", desempenho de $720 \mathrm{~mA} \cdot \mathrm{cm}^{-2}$ a $600 \mathrm{mV}$, igual ao apresentado pelo segundo melhor MEA confeccionado por Impressão à Tela (Sie25_02c - TAB.11) e 9,89\% menor que o melhor resultado (760 mA.cm ${ }^{-2}$ Sie25_04c - TAB.13). 
$\mathrm{Na}$ TAB.13, os dois MEAs fabricados pelo método de Aspersão e que não receberam o tratamento químico com $\mathrm{HNO}_{3}$, Spr25_01 e Spr25_02, apresentaram desempenho abaixo dos $600 \mathrm{~mA} \cdot \mathrm{cm}^{-2}$ no potencial de operação, cerca de $22 \%$ abaixo do melhor resultado obtido por um MEA confeccionado pelo mesmo método e tratado quimicamente. Estes resultados demonstram a importância do tratamento com $\mathrm{HNO}_{3}$.

Os resultados de três dos cinco MEAs apresentados na TAB.13, obtidos ao longo de toda a curva de polarização podem ser vistos na FIG.18.

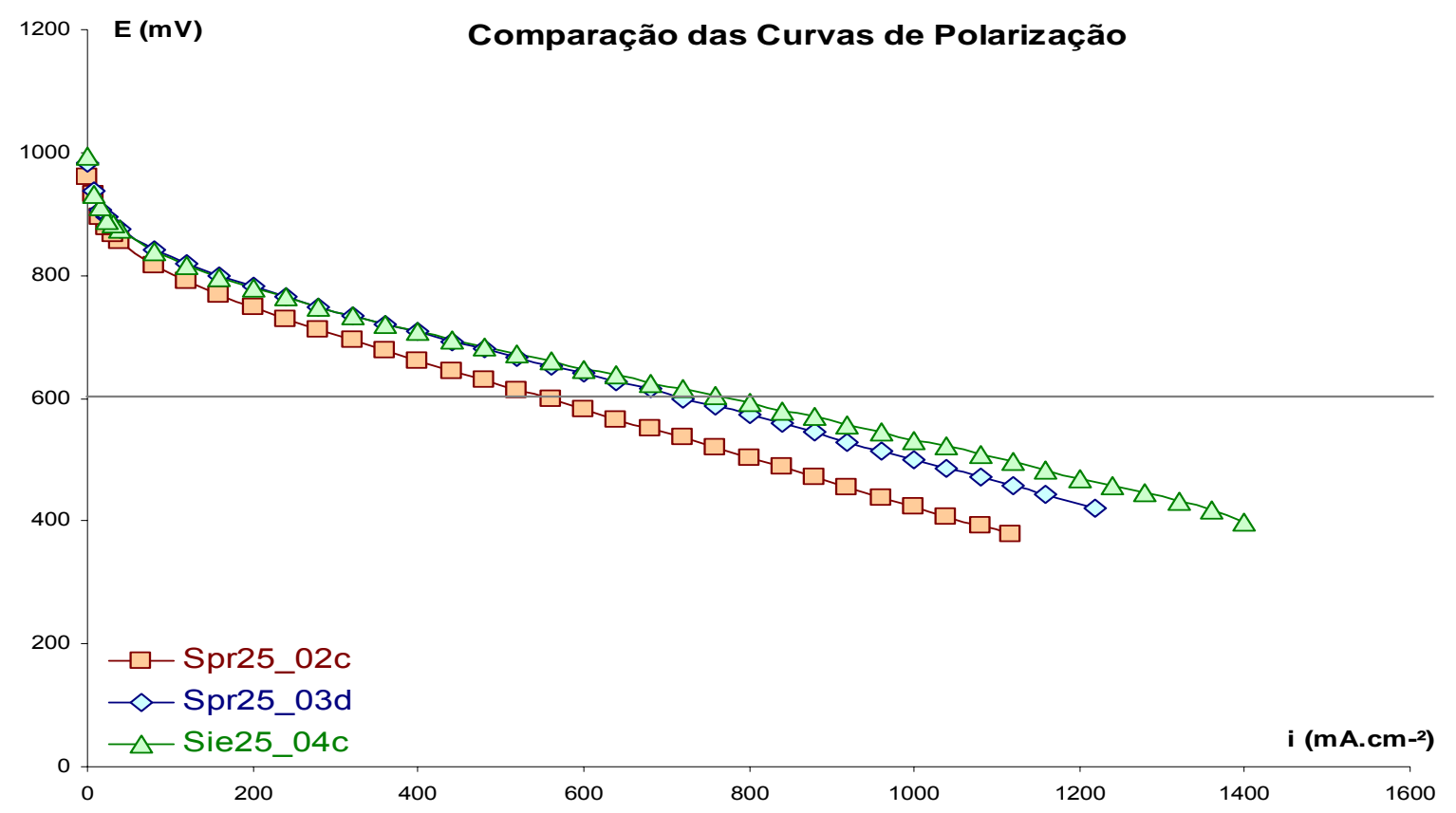

FIGURA 18- Curvas de Polarização dos melhores MEAs $\left(25 \mathrm{~cm}^{2}\right)$ com e sem tratamento químico posterior à confecção por Aspersão e do melhor MEA produzido por Impressão à Tela. Operação com $\mathrm{H}_{2} / \mathrm{O}_{2}$ puros. Umidificação somente no ânodo $\left(85^{\circ} \mathrm{C}\right)$. Vazões com o dobro da estequiometria. Temperatura de célula mantida a $70^{\circ} \mathrm{C}$.

Na FIG.18 são apresentadas as curvas de polarização dos melhores MEAs com e sem tratamento químico posterior à confecção por Aspersão e do melhor MEA produzido por Impressão à Tela. $\mathrm{Na}$ saída da região de predominância de polarização por ativação, a $780 \mathrm{mV}$, o conjunto Spr25_03 atingiu $200 \mathrm{~mA} . \mathrm{cm}^{-2}$ e o MEA Spr25_02, sem tratamento químico, apresentou $120 \mathrm{~mA} \cdot \mathrm{cm}^{-2}$, variação de $80 \mathrm{~mA} \cdot \mathrm{cm}^{-2}$ entre MEAs produzidos pelo mesmo método de deposição de eletrodo. Esta variação é conseqüência de um aumento significativo da polarização por ativação nos MEAs não tratados quimicamente. 
As curvas Sie25_04c (impressão à Tela) e Spr25_03d (Aspersão com tratamento químico) apresentaram os menores coeficientes angulares na região de queda ôhmica com valores de resistência iguais a $302 \mathrm{~m} \Omega . \mathrm{cm}^{2}$ para Sie25_04 e $346 \mathrm{~m} \Omega . \mathrm{cm}^{2}$ para o MEA Spr25_03. A curva Spr25_02c (Aspersão sem tratamento químico) demonstrou uma maior resistência, $399 \mathrm{~m} \Omega . \mathrm{cm}^{2}$.

Os resultados apresentados neste trabalho sugerem que a interferência no desempenho ocasionada pela realização de tratamento com $\mathrm{HNO}_{3}$ é benéfica para o MEA com melhoria significativa dos resultados apresentados nas curvas de polarização.

Novamente, os MEAs confeccionados por Aspersão foram comparados com o melhor resultado produzido por conjuntos preparados por Impressão à Tela, porém agora foram observados os pontos de potência máxima de suas melhores curvas (TAB.14).

TABELA 14 - Potência Máxima - Aspersão $\left(25 \mathrm{~cm}^{2}\right)$

\begin{tabular}{|c|c|c|c|c|c|c|}
\hline \multirow[b]{2}{*}{ PONTO } & \multirow{2}{*}{$\begin{array}{c}\text { MEA } \\
\text { (curva) }\end{array}$} & \multicolumn{5}{|c|}{ RESULTADOS OBTIDOS } \\
\hline & & $\begin{array}{c}\text { I } \\
\text { (A) }\end{array}$ & $\begin{array}{c}i \\
\left(\mathrm{~mA} \cdot \mathrm{cm}^{-2}\right)\end{array}$ & $\begin{array}{c}E \\
(\mathrm{mV})\end{array}$ & $\begin{array}{c}P \\
(W)\end{array}$ & $\begin{array}{c}p \\
\left(\mathrm{~mW} \cdot \mathrm{cm}^{-2}\right)\end{array}$ \\
\hline \multirow{5}{*}{$P_{\text {máx }}$} & Spr25_01d & 23,0 & 920 & 457 & 10,51 & 420,44 \\
\hline & Spr25_02c & 26,0 & 1.040 & 408 & 10,61 & 424,32 \\
\hline & Spr25_03d & 29,0 & 1.160 & 443 & 12,85 & 513,88 \\
\hline & Spr25_04b & 30,5 & 1.220 & 407 & 12,42 & 496,64 \\
\hline & Sie25_04c & 33,0 & 1.320 & 432 & 14,26 & 570,24 \\
\hline
\end{tabular}

Os MEAs Spr25_01 e Spr25_02 apresentaram densidade de potência máxima inferior a $425 \mathrm{~mW} . \mathrm{cm}^{-2}$, enquanto os conjuntos Spr25_03 e Spr25_04 obtiveram valores maiores do que $495 \mathrm{~mW} \cdot \mathrm{cm}^{-2}$. Todos os resultados apresentados pelos conjuntos fabricados por Aspersão foram menores que os resultados do conjunto confeccionado por Impressão à Tela.

As melhores curvas de potência dos MEAs com e sem tratamento químico são comparadas na FIG.19 juntamente com o melhor MEA confeccionado por Impressão à Tela. 


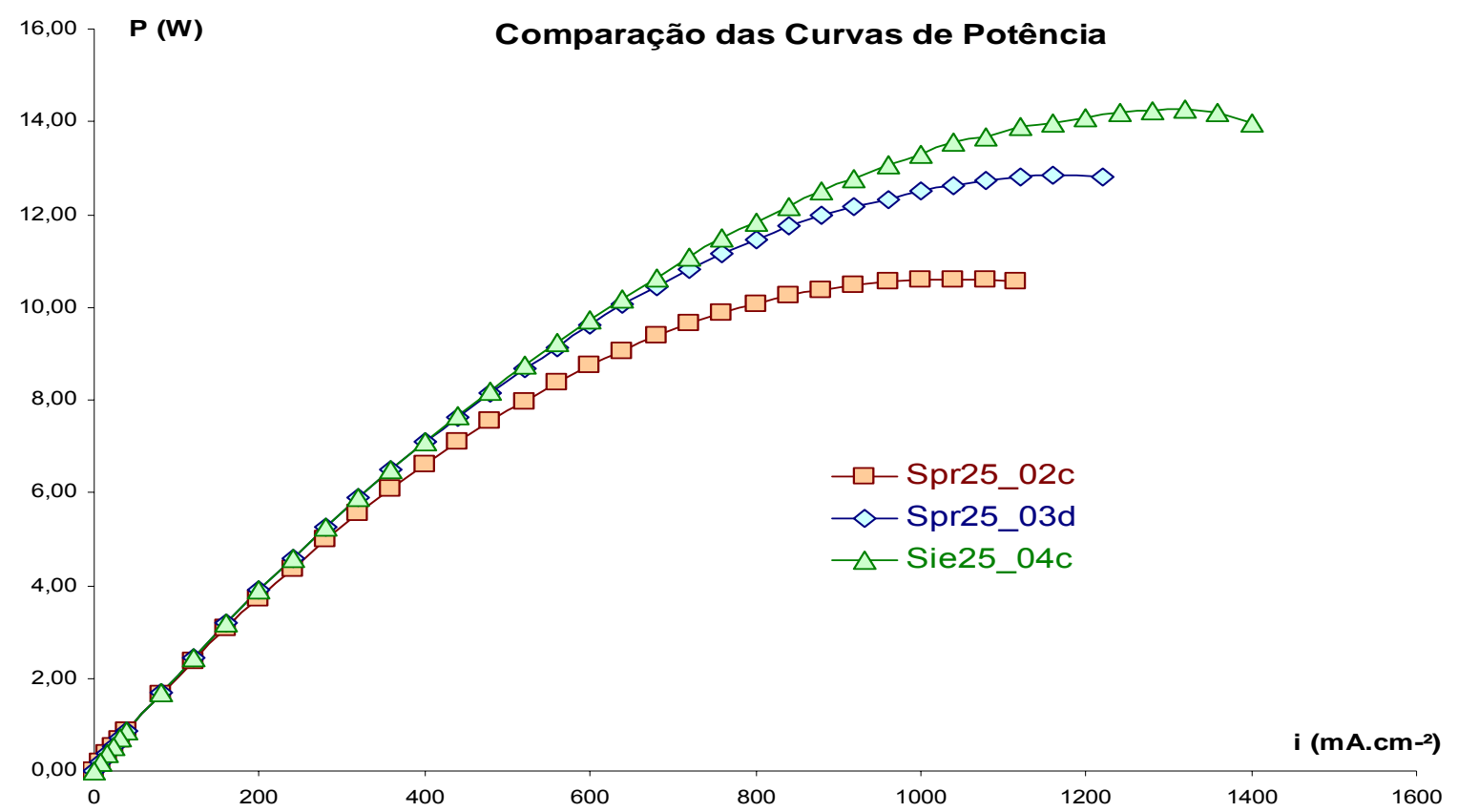

FIGURA 19- Curvas de Potência dos melhores MEAs $\left(25 \mathrm{~cm}^{2}\right)$ com e sem tratamento químico posterior à confecção por Aspersão e do melhor MEA produzido por Impressão à Tela. Operação com $\mathrm{H}_{2} / \mathrm{O}_{2}$ puros. Umidificação somente no ânodo $\left(85^{\circ} \mathrm{C}\right)$. Vazões com o dobro da estequiometria. Temperatura de célula mantida a $70^{\circ} \mathrm{C}$.

Na FIG.19 o início do descolamento da curva Spr25_02c das demais é percebido a partir dos $200 \mathrm{~mA} \cdot \mathrm{cm}^{-2}$, evidenciando a grande queda de potência deste conjunto. Os outros dois MEAs apresentaram melhor desempenho, sendo que o conjunto Sie25_04, confeccionado por Impressão à Tela, apresentou os melhores resultados ao longo de toda a curva de potência.

Os resultados alcançados nos experimentos de comparação de desempenho entre conjuntos de $25 \mathrm{~cm}^{2}$ de área ativa preparados pelos processos de Impressão à Tela e de Aspersão demonstram que os dois processos são equivalentes em relação ao desempenho dos conjuntos gerados, desde que o processo de tratamento químico do $\mathrm{MEA}$ com $\mathrm{HNO}_{3}$ seja associado ao processo de deposição do eletrodo.

\subsection{Projeto Célula Unitária}

Foram desenhados modelos, mostrados nas FIG.20 a 22, que correspondem à região de início de dois canais conjugados e abrangem uma parte do canal de entrada (com 1,5 $\mathrm{mm}$ de espessura) e continuam até $2 \mathrm{~mm}$ de comprimento de cada um dos canais do perfil. A região em vermelho corresponde 
à entrada de gás. A região verde é a área de distribuição. A região em azul representa os canais e o retângulo transparente superior identifica a posição da camada difusora. As direções x, y e z são indicadas nas respectivas figuras.

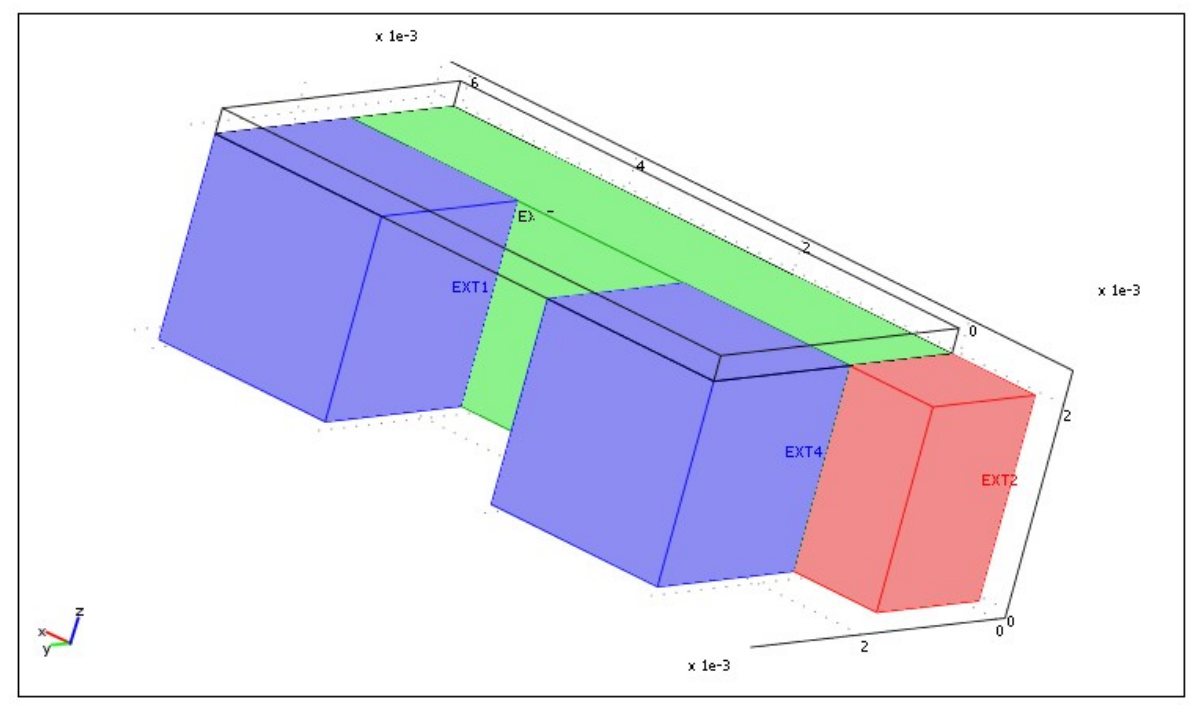

FIGURA 20 - PQ20 - canal quadrado (2 mm), parede quadrada (2 mm)

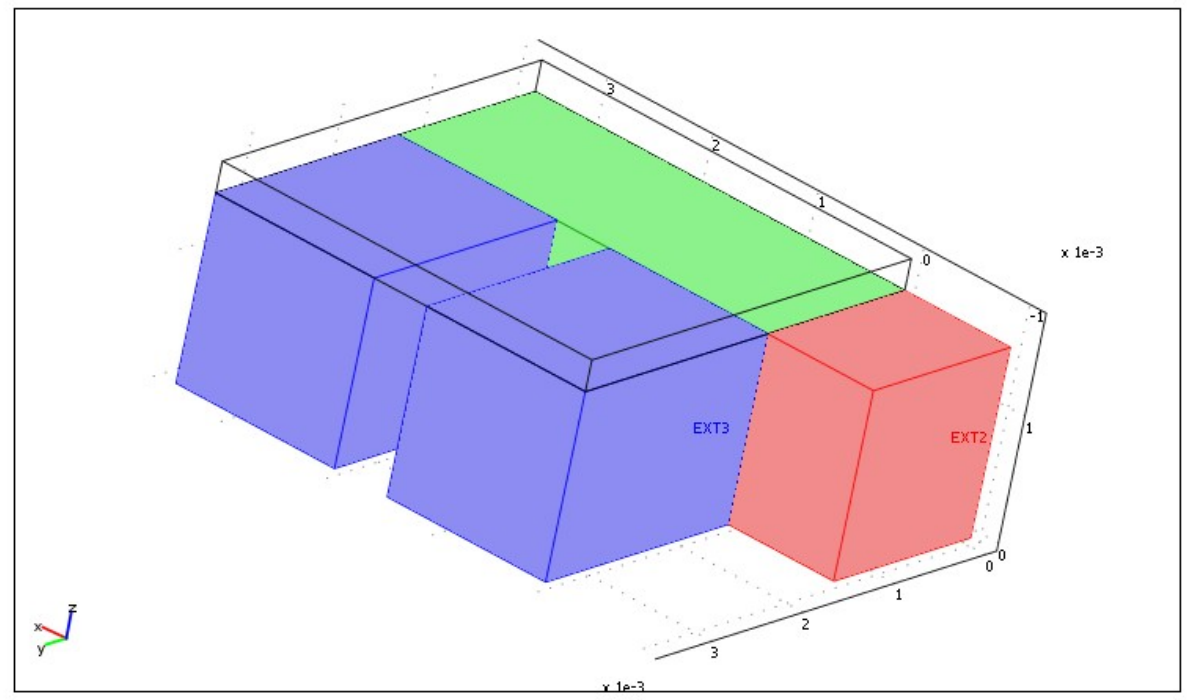

FIGURA 21 - PQ15 - canal quadrado $(1,5 \mathrm{~mm})$, parede de 0,5 $\mathrm{mm} \times 1,5 \mathrm{~mm}$ 


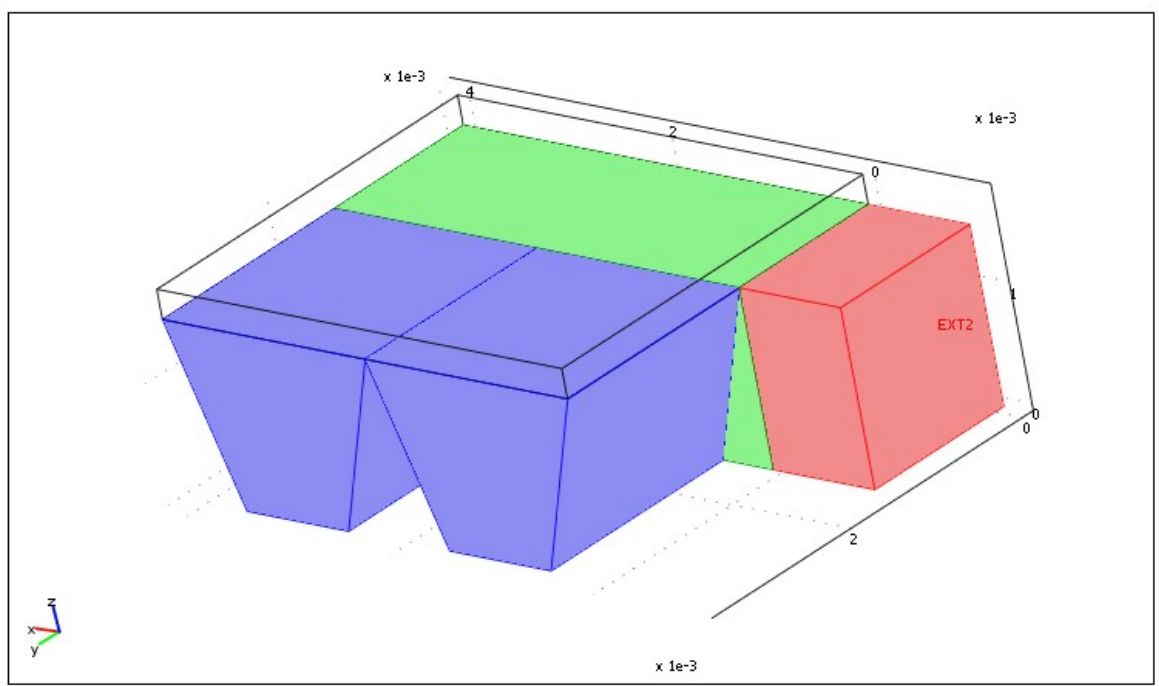

FIGURA 22 - PT - canal trapezoidal $(b=1 \mathrm{~mm} ; \mathrm{B}=2 \mathrm{~mm})$, parede triangular

Os gráficos de pressão e velocidade para os três perfis de canal (FIG.23 a 28) foram calculados através de FDC pelas equações de navier-stokes (18) e de continuidade (19) segundo condições de contorno (ver item 4.7.1).

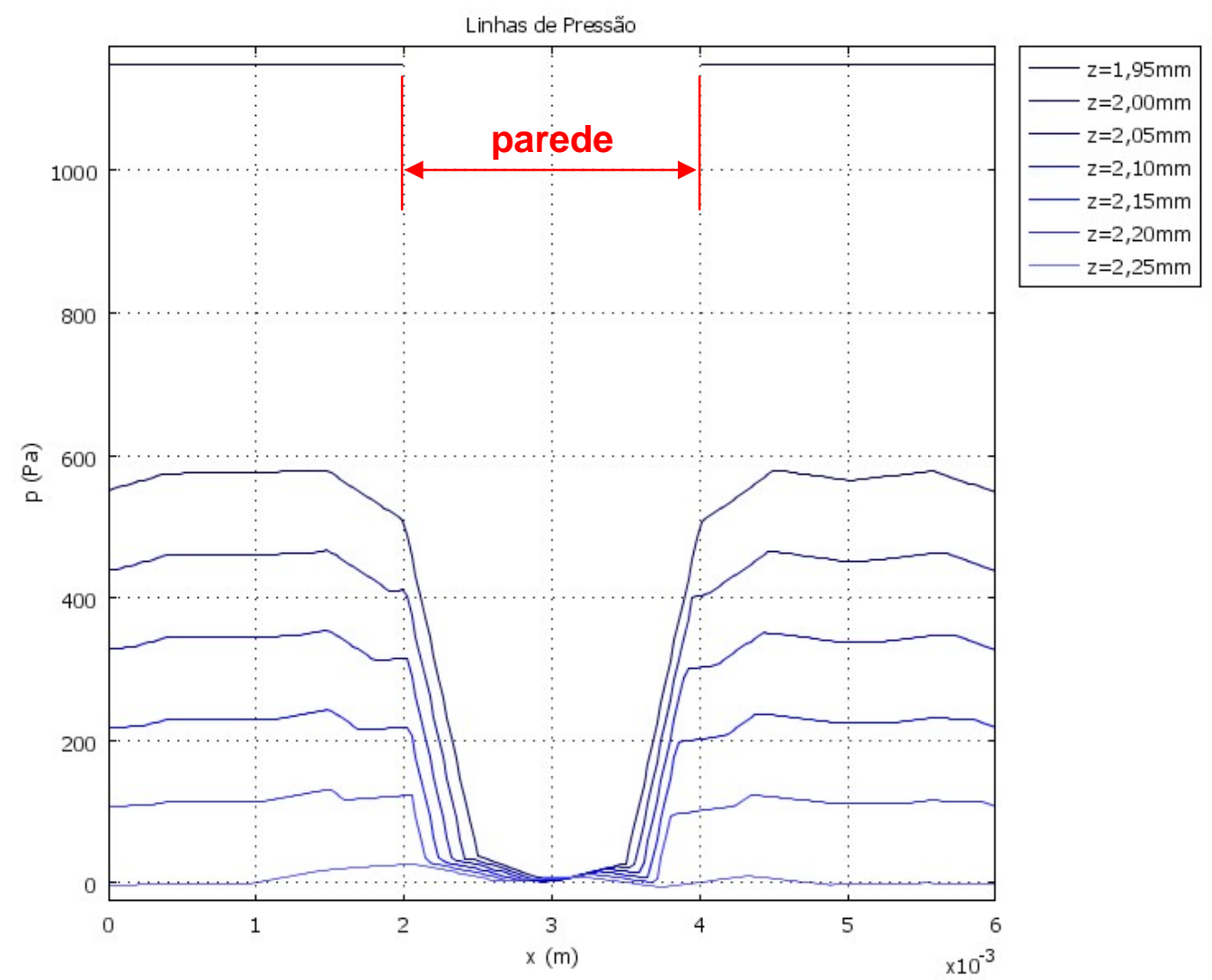

FIGURA 23 - Linhas de Pressão, PQ20, y = 3,5 mm 


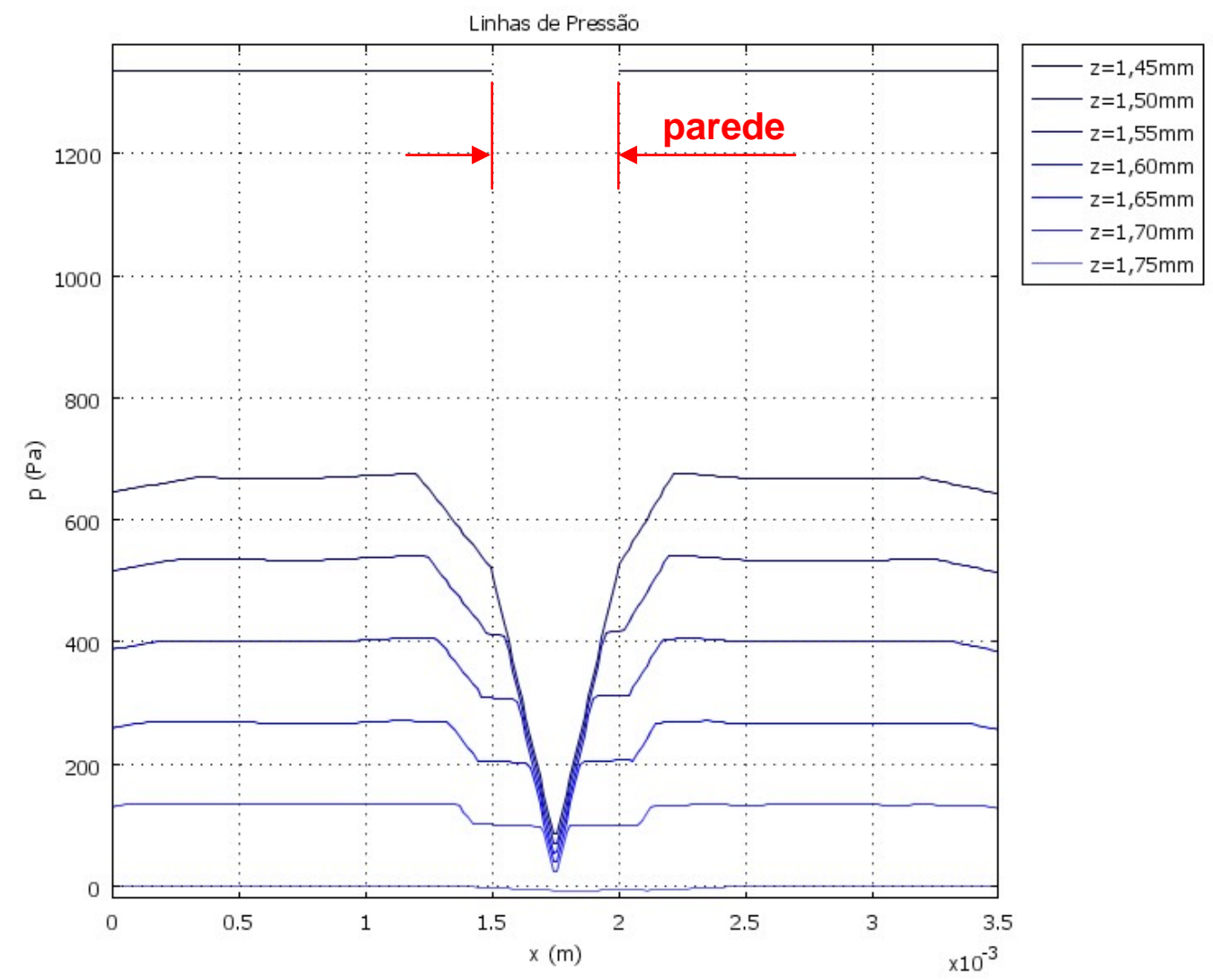

FIGURA 24 - Linhas de Pressão, PQ15, y = 3,5 mm

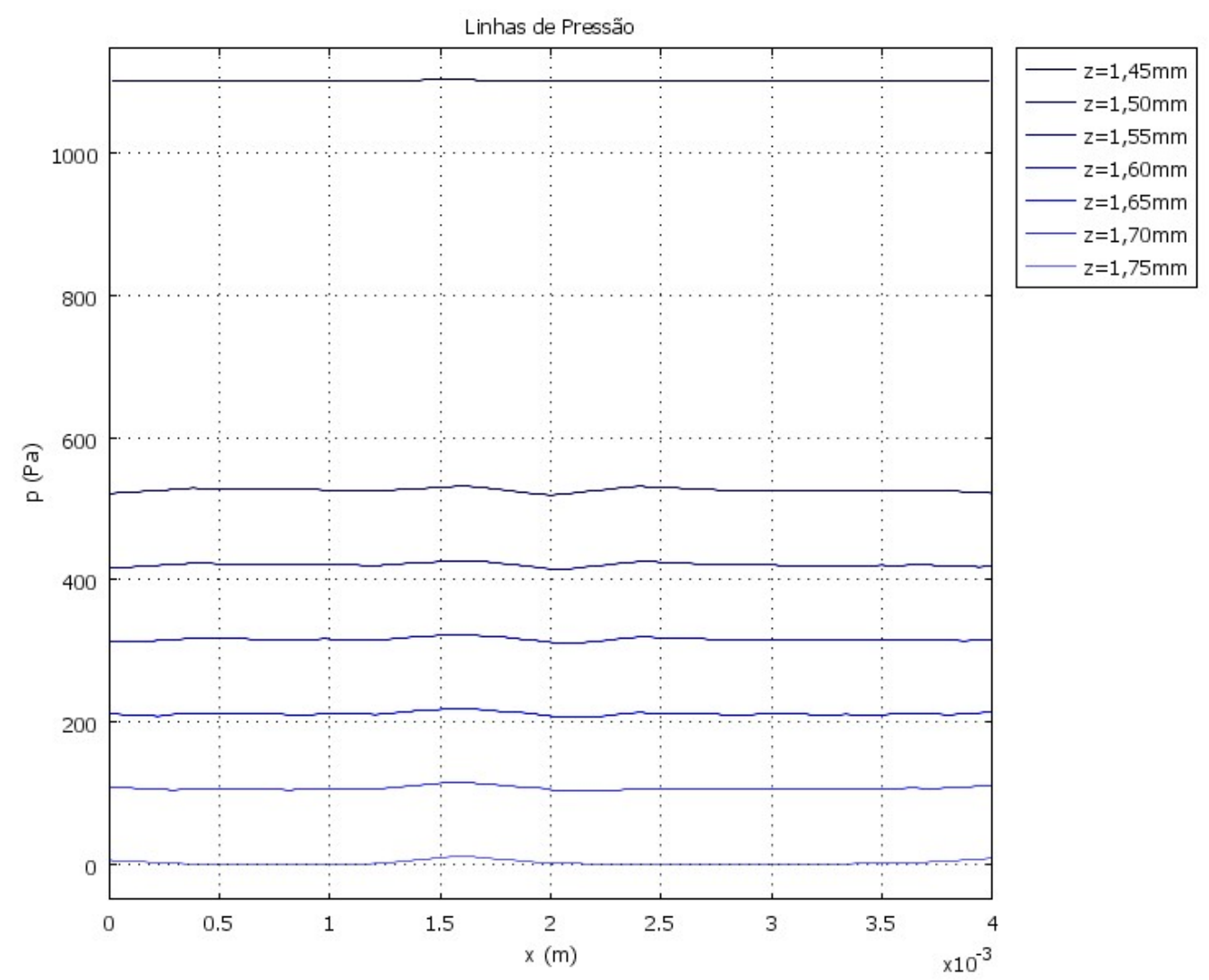

FIGURA 25 - Linhas de Pressão, PT, y = 3,5 mm 


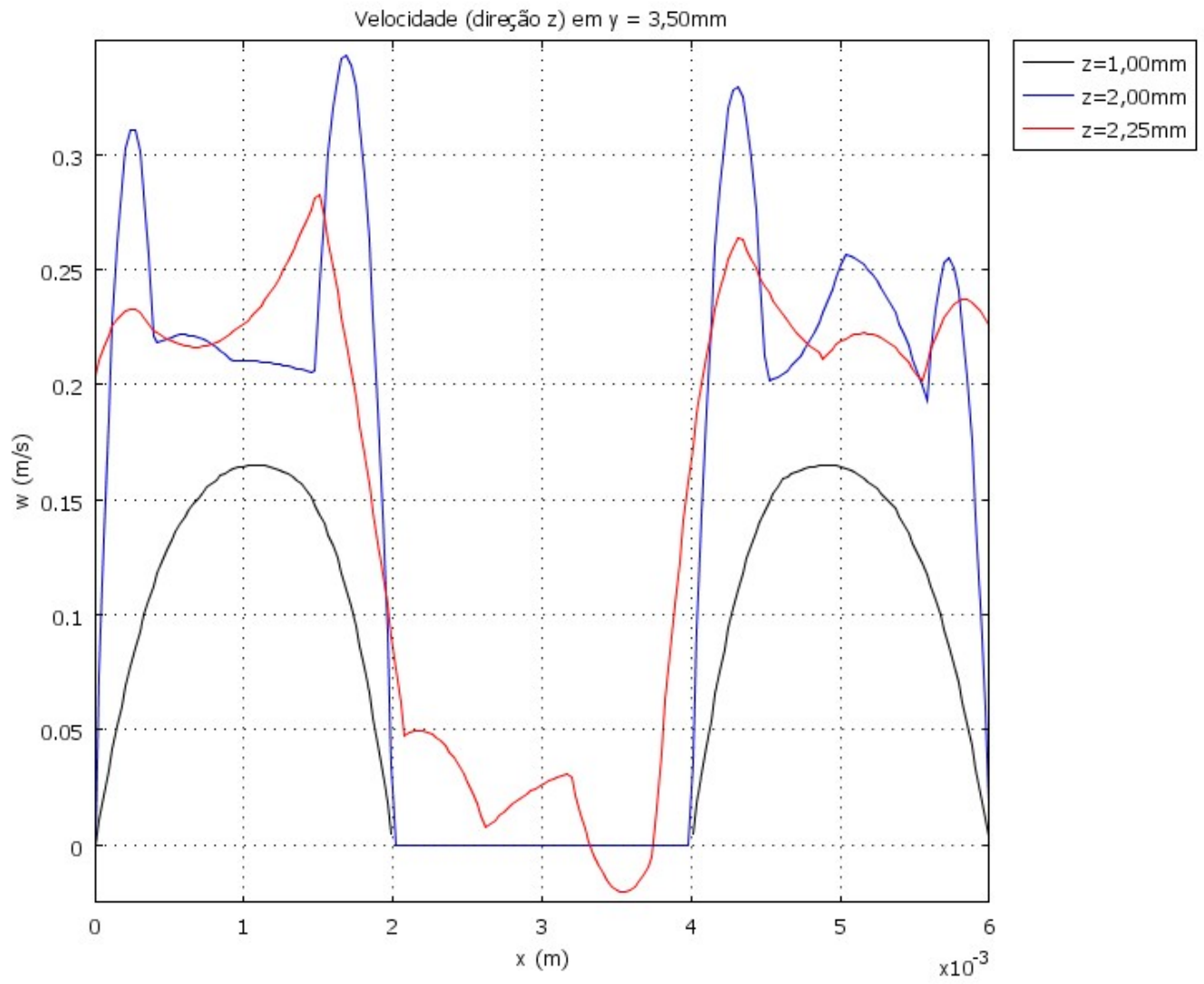

FIGURA 26 - Velocidade (direção z), PQ20, y = 3,5 mm

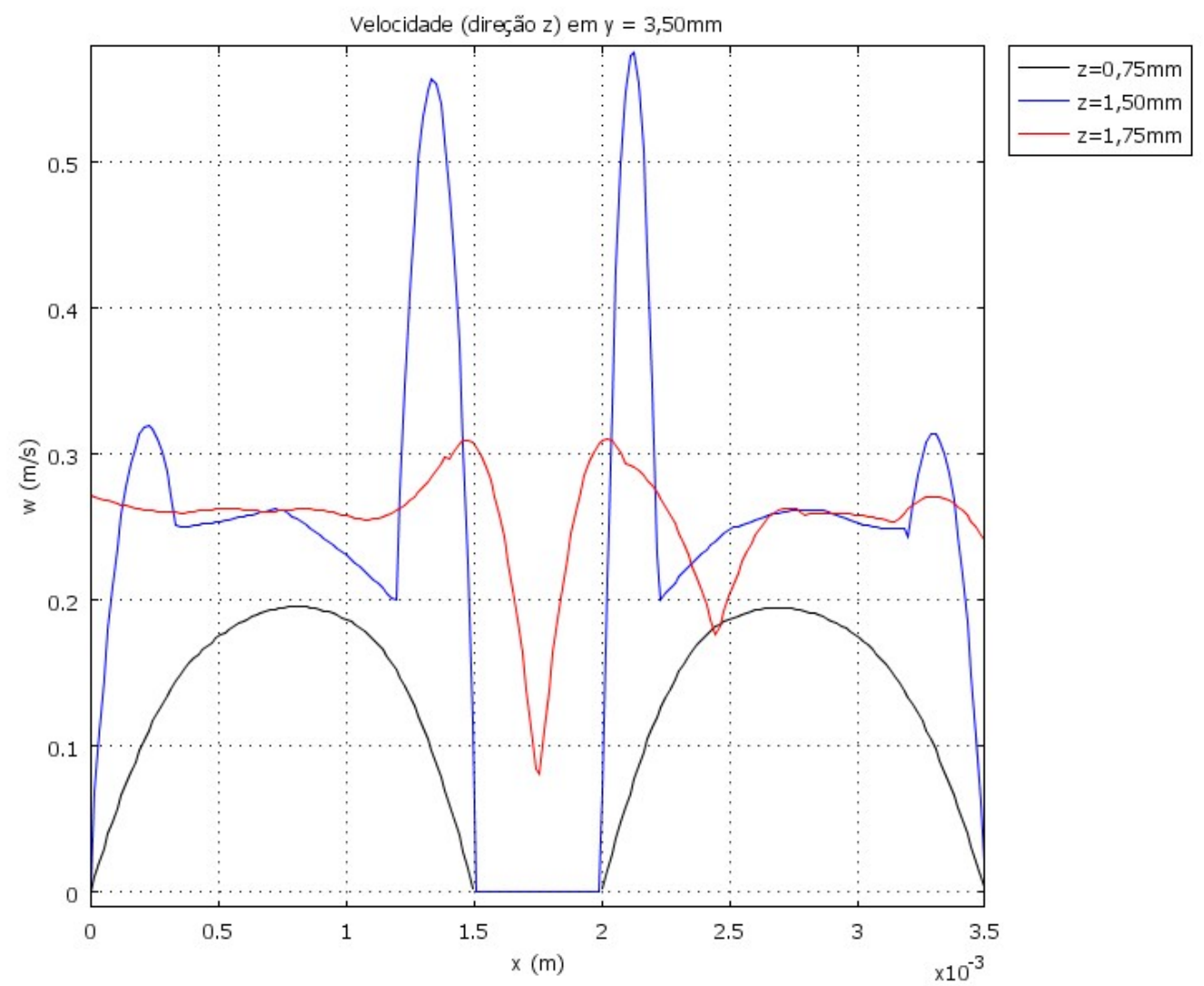

FIGURA 27 - Velocidade (direção z), PQ15, y = 3,5 mm 


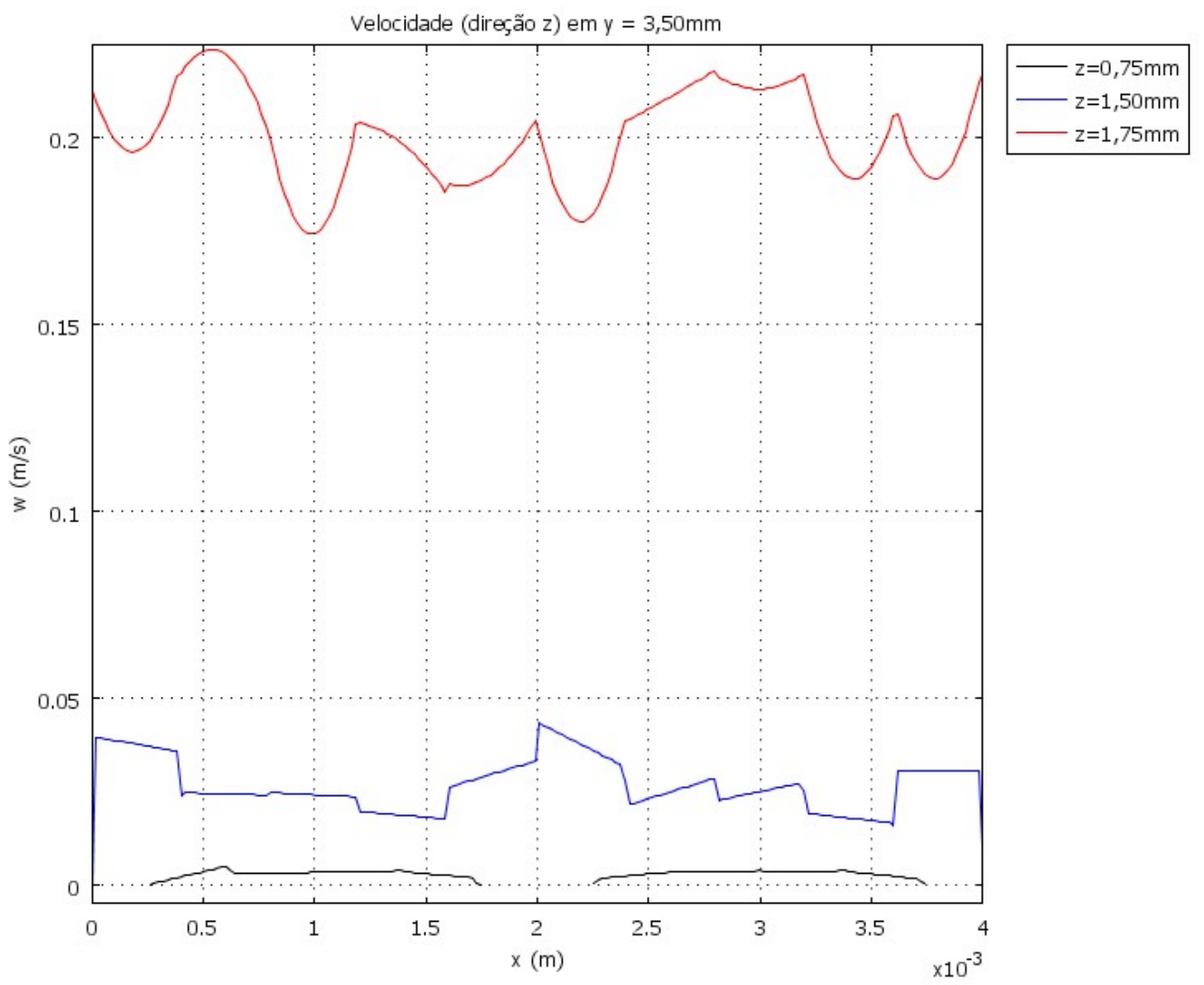

FIGURA 28 - Velocidade (direção z), PT, y = 3,5 mm

De acordo com os gráficos apresentados, FIG.23 a 28, percebe-se uma grande região de estagnação no topo da parede entre os canais de perfil quadrado de 2,0 mm. Na FIG.23 este efeito é percebido pela não existência de um grande gradiente de pressão na faixa compreendida entre 2,50 mm e 3,50 mm (todas as linhas de pressão estão muito próximas de zero). No gráfico de velocidades de PQ20, FIG.26, é notória a região de baixas velocidades em z, fato que confirma o resultado obtido pelas linhas de pressão. O perfil PQ15 apresenta estagnação, porém esta é pontual em torno de $x=1,75 \mathrm{~mm}$ (FIG.24). Embora os canais de perfil trapezoidal, PT, tenham apresentado na FIG.25 gradientes de pressão, $\Delta p$, em torno de $1,1 \mathrm{kPa}$, que são menores que aqueles encontrados para o PQ15 na FIG.24 (com $\Delta$ p aproximadamente igual a 1,3 kPa), o valor da velocidade na direção $z$ no canal trapezoidal manteve-se em torno de 0,2 m.s ${ }^{-1}$ ao longo de todo eixo x para z igual a 1,75 mm (FIG.28), ao contrário dos outros dois perfis de canal que apresentaram áreas ou pontos de grande quedas de velocidade chegando a atingir velocidades abaixo de $0,1 \mathrm{~m} \cdot \mathrm{s}^{-1}$ na saída da região da camada difusora para z igual a 2,25 mm em PQ20 (FIG.26), e z igual a 1,75 mm em PQ15 (FIG.27). 
Em suma, os dois perfis desenvolvidos neste trabalho (PQ15 e PT) apresentaram melhores resultados numéricos do que o perfil já existente no IPEN (PQ20) no estudo de FDC.

Do APÊNDICE B ao APÊNDICE D são apresentadas as gravuras obtidas com representações de zonas de pressão e de velocidade para os perfis estudados.

Segundo os resultados obtidos, placas de grafite com os dois perfis desenvolvidos foram projetadas. O resultado do projeto Célula Unitária é apresentado a seguir.

- Características Gerais: apresentadas na TAB.15 são relativas ao uso, à materiais, à dimensões, à vedação, ao perfil de canal, ao sistema de aquecimento e à alimentação de gases da célula projetada.

TABELA 15 - Características Gerais de Projeto $\left(144 \mathrm{~cm}^{2}\right)$

\begin{tabular}{l|l}
\hline \multicolumn{1}{c|}{ ASSUNTO } & \multicolumn{1}{c}{ DETALHAMENTO DA INFORMAÇÃo } \\
\hline Uso & $\begin{array}{l}\text { A célula unitária permite o uso de MEAs }\left(144 \mathrm{~cm}^{2}\right) \text { comerciais e } \\
\text { produzidos no próprio laboratório. Os MEAs possuem seção } \\
\text { quadrada. A célula apresenta facilidade para a realização de } \\
\text { medidas e conexão de equipamentos (multímetro e carga } \\
\text { dinâmica). }\end{array}$ \\
\hline Materiais & $\begin{array}{l}\text { Grafite impregnada (Qualidade ELLOR+25/45) foi utilizada no } \\
\text { par de placas de direcionamento de gases e coleta de elétrons. } \\
\text { Cobre eletrolítico (com deposição superficial de ouro) foi } \\
\text { utilizado no par de placas para escoamento eletrônico. Alumínio } \\
\text { foi utilizado no par de placas com função estrutural. }\end{array}$ \\
\hline Dimensões & $\begin{array}{l}\text { Placas de Grafite }-187 \times 187 \times 4 \text { mm. } \\
\text { Placas de Cobre }-187 \times 200 \times 1 \text { mm. } \\
\text { Placas de Alumínio }-187 \times 187 \times 10 \text { mm. }\end{array}$ \\
\hline Vedação & Utilizado Viton ${ }^{\circledR}$ para os anéis de vedação. \\
\hline Perfil de Canal & Quadrado e Trapezoidal \\
\hline Aquecimento & $\begin{array}{l}\text { Resistências em tarugo }(\varnothing 6,35 \mathrm{~mm}, 120 \mathrm{~mm} \text { de comprimento, } \\
60 \text { W } / 110 \text { V). }\end{array}$ \\
\hline Alimentação & Conexões de engate rápido da Festo ${ }^{\circledR}$. \\
\hline
\end{tabular}

- Projeto: O detalhamento é mostrado do APÊNDICE E ao APÊNDICE O;

- Construção da Célula Unitária conforme projeto: O material das quatro placas de grafite impregnadas foram compradas da Carbono Lorena. Duas placas de grafite (canal de perfil quadrado - PQ15) foram construídas em oficina do Centro Universitário da FEl. As placas metálicas (duas de cobre e duas de alumínio) foram usinadas em oficina do Departamento de Física 
da USP. A usinagem das outras duas placas de grafite (canal de perfil trapezoidal - PT) foi encomendada à Carbono Lorena e embora tenham sido realizados os estudos de FDC, até a conclusão deste trabalho tais placas não haviam sido entregues. A douração das placas de cobre foi realizada pela empresa Marilize Decorações e Restaurações S/C Ltda. As resistências elétricas foram adquiridas da Produtos Elétricos Palley Ltda.

No projeto de aumento de escala algumas das soluções anteriores não surtiram o efeito desejado. A definição do uso de resistências de aquecimento foi uma destas soluções. Com a operação percebeu-se que a própria célula é capaz de gerar calor suficiente para se manter. Inclusive, em altas correntes, há necessidade de refrigeração do conjunto. Portanto, em trabalhos posteriores a esta dissertação, poder-se-ia estudar o projeto de placas estruturais com funções de arrefecimento e não de abrigo de sistema de aquecimento como o apresentado aqui. No intuito de diminuir componentes, o projeto da célula unitária não utilizou anéis de vedação como elementos de vedação entre a placa de cobre e a de grafite. O silicone, alta temperatura RTV, destinado a esta função provavelmente reagiu com o hidrogênio e perdeu sua capacidade de vedação. Uma solução possível seria o uso de anéis de vedação entre a placa de cobre e a de grafite.

\subsection{Tratamento Térmico da Membrana $\left(144 \mathrm{~cm}^{2}\right)$}

Os experimentos foram realizados em estufa com circulação a $125{ }^{\circ} \mathrm{C}$. As membranas permaneceram nesta condição por 30 minutos. Na TAB.16 são apresentados estes resultados.

TABELA 16 - Resultados do Tratamento Térmico da Membrana $\left(144 \mathrm{~cm}^{2}\right)$

\begin{tabular}{ccc}
\hline MEMBRANA & FIXAÇÃo & RESULTADO \\
\hline M1 & Presa em Moldura & Rasgou \\
\hline M2 & $\begin{array}{c}\text { Sob armação quadrada } \\
\text { vazada no meio }\end{array}$ & Ideal para pintura \\
\hline M3 & $\begin{array}{c}\text { Sob quatro pequenos } \\
\text { pesos nos vértices }\end{array}$ & $\begin{array}{c}\text { Propícia para pintura, porém } \\
\text { apresentou bordas enrugadas. }\end{array}$ \\
\hline
\end{tabular}

O tratamento térmico da membrana para $144 \mathrm{~cm}^{2}$ de área ativa não apresentou o mesmo resultado que aquele para $25 \mathrm{~cm}^{2}$. A membrana presa à 
moldura rasgou. Este resultado, provavelmente deveu-se ao fato de que a maior área quando submetida a este tratamento apresente uma maior redução dimensional, e se estiver presa, pode gerar maiores tensões de cisalhamento. Tanto o uso da armação vazada como o uso dos pequenos pesos, foram adequados a este tamanho de membrana. Recomenda-se o uso da armação vazada por facilitar o manuseio e por causar menor dano à membrana.

\subsection{Parâmetros da Preparação da Pasta, da Máquina e da Prensagem}

Os aumentos de escala e de lotes de pintura no processo de Impressão à Tela implicaram na necessidade de se ter maiores quantidades de tinta disponível. Para diminuir a perda durante a fabricação da tinta, maiores quantidades deveriam ser produzidas e este experimento foi realizado neste sentido. Para execução deste experimento foram utilizados o carbono Vulcan XC72R da Cabot, a Solução de Nafion 5\% em massa, o solvente 2EEA, o eletrocatalisador E-TEK 20\% HP Pt sobre vulcan XC-72R e a água ultrapura. Os resultados encontrados estão descritos na TAB.17.

TABELA 17 - Resultados Preparação da Pasta $\left(144 \mathrm{~cm}^{2}\right)$

\begin{tabular}{|c|c|c|c|c|c|c|c|}
\hline \multicolumn{2}{|c|}{ EXPERIMENTO } & \multirow{2}{*}{\begin{tabular}{|c} 
CARBONO \\
$(\mathrm{g})$
\end{tabular}} & \multirow{2}{*}{$\begin{array}{c}\text { Pt ETEK } \\
\text { (g) } \\
-\end{array}$} & \multirow{2}{*}{$\begin{array}{c}\text { NAFION } \\
(\mathrm{g}) \\
107,70\end{array}$} & \multirow{2}{*}{$\begin{array}{c}\text { 2EEA } \\
(\mathrm{g}) \\
5,00\end{array}$} & \multirow{2}{*}{$\begin{array}{c}\mathrm{H}_{2} \mathrm{O} \\
(\mathrm{g}) \\
10,00 \\
+ \\
5,00\end{array}$} & \multirow{2}{*}{$\begin{array}{l}\text { SOL.2:1 } \\
\qquad(\mathrm{g}) \\
-\end{array}$} \\
\hline 1 & $\mathrm{P}$ & & & & & & \\
\hline 1 & $\mathrm{R}$ & 10,02 & - & 109,62 & 5,03 & $\begin{array}{c}10,01 \\
+ \\
5,12\end{array}$ & - \\
\hline \multirow{2}{*}{2} & $\mathrm{P}$ & - & 10,00 & 108,00 & - & - & $\begin{array}{r}15,00: \\
7,50\end{array}$ \\
\hline & $\mathrm{R}$ & - & 10,06 & 108,05 & - & - & $\begin{array}{c}15,02: \\
7,51\end{array}$ \\
\hline \multirow{2}{*}{3} & $\mathrm{P}$ & - & 20,00 & 216,00 & - & - & $\begin{array}{c}30,00: \\
15,00\end{array}$ \\
\hline & $\mathrm{R}$ & - & 20,00 & 216,17 & - & - & $\begin{array}{c}30,00: \\
14,99\end{array}$ \\
\hline
\end{tabular}

A expressão "Sol.2:1" na TAB.17 é correspondente à solução de água/2EEA na proporção 2:1 adicionada à tinta. Na mesma tabela, a respeito da adição de água, é apresentada na coluna $\mathrm{H}_{2} \mathrm{O}$ uma soma para representar que a 
adição ocorreu em momentos diferentes. A tinta do experimento 1 secava e endurecia muito rapidamente impossibilitando a pintura. A tinta do experimento 2 foi ideal para a Impressão à Tela. A tinta do experimento 3 entrou em combustão durante o processo de evaporação.

A tinta do experimento 1 secava muito rapidamente e por isto, no experimento 2 a água e o 2EEA foram adicionados em solução e não separadamente para verificar se este procedimento poderia diminuir a evaporação. A tinta do experimento 3 entrou em combustão, provavelmente, em função do aumento de temperatura no agitador magnético durante a evaporação. Quanto menor a massa de tinta no becker, maior será a temperatura para um mesmo nível de aquecimento do agitador magnético. Assim, o mais provável é que a evaporação começou lenta e com a perda de massa o calor gerado foi tão grande que a tinta entrou em combustão. Para solucionar este problema, foi utilizada uma atmosfera de gás inerte durante o processo de evaporação no preparo de uma pasta posterior.

No experimento de adequação da altura de mesa, a impressão no papel ficou bem definida apresentando vértices e bordas laterais sem borrões ou manchas de indefinição conforme evidenciado na FIG.29.
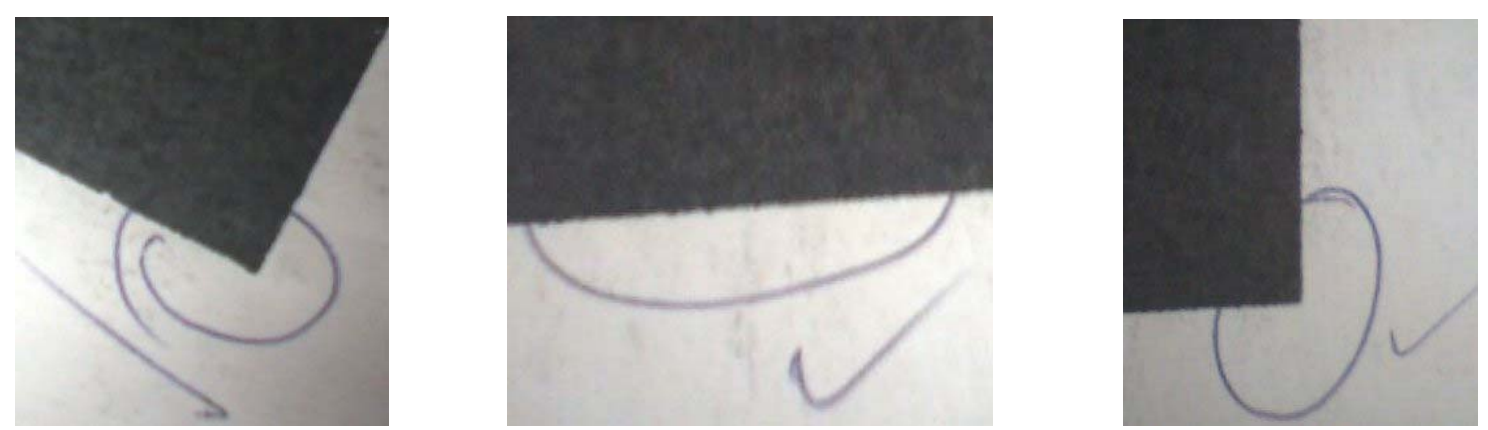

FIGURA 29 - Impressão do experimento de altura de mesa

Nos dois primeiros experimentos de secagem entre passadas, as membranas permaneceram na estufa por um período médio de cinco minutos. No último experimento o tempo foi condicionado ao processo de pintura, isto é, enquanto a membrana anterior secava sob lâmpadas a posterior era pintada. $A$ secagem em estufa não foi suficiente para preparar as membranas para a próxima deposição da pasta catalítica. Quando a membrana entrava em contato com a tela da máquina, partes que ainda não estavam secas da camada depositada eram arrancadas da membrana e as partes secas recebiam a 
segunda deposição. O resultado é um quadrado pintado com diversas falhas de deposição, normalmente na forma de riscos longos ou áreas amorfas. As membranas secas sob o banco de lâmpadas apresentaram áreas bem definidas e sem falhas. O procedimento de secagem sob lâmpadas desponta como a melhor solução para manter a membrana lisa e propícia para receber diversas camadas de um mesmo eletrodo. Durante o experimento de prensagem a quente, os quatros MEAs só não apresentaram descolamento logo após processo de prensagem quando foi utilizada a carga de $444,33 \mathrm{kgf.} \mathrm{cm}^{-2}$ por cinco minutos. Os MEAs produzidos para este experimento foram comparados posteriormente quanto ao desempenho em bancada com MEAs comerciais.

\subsection{Estimativa de Perdas}

As massas, inicial e final, bem como a diferença entre elas para os reservatórios das tintas utilizadas na Impressão à Tela são apresentadas na TAB.18 para três lotes diferentes de tinta.

TABELA 18 - Resultados Massas dos Potes $\left(144 \mathrm{~cm}^{2}\right)$

\begin{tabular}{c|c|c|c}
\hline \multirow{2}{*}{ LOTE } & \multicolumn{3}{|c}{ MASSA DO POTE DE PASTA CATALÍTICA } \\
\cline { 2 - 4 } & INICIAL & FINAL & DIFERENÇA \\
\hline 1 & $296,565 \mathrm{~g}$ & $245,407 \mathrm{~g}$ & $51,158 \mathrm{~g}$ \\
\hline 2 & $243,930 \mathrm{~g}$ & $204,010 \mathrm{~g}$ & $39,920 \mathrm{~g}$ \\
\hline 3 & $222,123 \mathrm{~g}$ & $205,989 \mathrm{~g}$ & $16,134 \mathrm{~g}$ \\
\hline
\end{tabular}

Percebeu-se na produção do lote 1 que as duas primeiras passadas de um mesmo eletrodo eram as que mais depositavam catalisador sobre a membrana. Além disso, mesmo sob lâmpada, a membrana necessitava de um tempo de secagem um pouco maior para receber a terceira camada sem perder pasta para a peneira da máquina. A partir do lote 2 uma regra de deposição foi implementada: a cada duas passadas a peneira era limpa na região de deposição. Esta situação gerava tempo suficiente para o MEA secar e ainda recomeçava com grandes deposições de tinta sobre a membrana, além de conferir maior agilidade ao processo (não há entupimento da peneira) e maior controle. Foi notado que a média de deposição com a prática da regra de deposição é de $0,2 \mathrm{mgPt} . \mathrm{cm}^{-2}$ a cada duas passadas. O lote 3 foi pintado por um único operador. 
Na TAB.19 são mostradas as cargas dos eletrodos secos depositados por lote.

TABELA 19 - Resultados Cargas Depositadas $\left(144 \mathrm{~cm}^{2}\right)$

\begin{tabular}{|c|c|c|c|c|c|c|}
\hline \multirow[b]{2}{*}{ LOTE } & \multirow[b]{2}{*}{ MEA } & \multicolumn{2}{|c|}{ Ânodo } & \multicolumn{2}{|c|}{ Cátodo } & \multirow{2}{*}{$\begin{array}{c}\text { Total } \\
\text { Eletrodo } \\
\text { (g) }\end{array}$} \\
\hline & & $\begin{array}{c}\mathbf{P t} \\
\left(\mathrm{mg} \cdot \mathrm{cm}^{-2}\right)\end{array}$ & $\begin{array}{l}\text { Nafion }^{\circledR} \\
\left(\mathrm{mg} \cdot \mathrm{cm}^{-2}\right)\end{array}$ & $\begin{array}{c}\mathbf{P t} \\
\left(\mathrm{mg} \cdot \mathrm{cm}^{-2}\right)\end{array}$ & $\begin{array}{l}\text { Nafion }^{\circledR} \\
\left(\mathrm{mg} \cdot \mathrm{cm}^{-2}\right)\end{array}$ & \\
\hline \multirow{4}{*}{1} & E1 & 0,408 & 1,098 & 0,590 & 1,588 & \multirow{4}{*}{4,182} \\
\hline & E2 & 0,413 & 1,112 & 0,531 & 1,430 & \\
\hline & Sie144_01 & 0,421 & 1,133 & 0,469 & 1,263 & \\
\hline & Sie144_02 & 0,458 & 1,233 & 0,485 & 1,306 & \\
\hline \multirow{4}{*}{2} & E3 & 0,439 & 1,182 & 0,635 & 1,710 & \multirow{4}{*}{4,908} \\
\hline & E4 & 0,461 & 1,241 & 0,625 & 1,683 & \\
\hline & E5 & 0,462 & 1,244 & 0,679 & 1,828 & \\
\hline & E6 & 0,433 & 1,166 & 0,697 & 1,877 & \\
\hline \multirow{2}{*}{3} & Sie144_03 & 0,316 & 0,851 & 0,457 & 1,230 & \multirow{2}{*}{1,737} \\
\hline & Sie144_04 & 0,316 & 0,851 & 0,479 & 1,290 & \\
\hline
\end{tabular}

Considera-se que a pasta catalítica é composta por $30 \%$ em massa de sólidos (platina, carbono e $\mathrm{Nafion}^{\circledR}$ seco), assim para calcular a perda as seguintes relações foram utilizadas:

$$
m_{e s}=(30 \%) m_{p d},
$$

onde, $m_{e s}$ representa a massa dos eletrodos secos depositados e $m_{p d}$ representa a massa da pasta depositada. $O$ total de perda de massa catalítica é calculado segundo a expressão (21).

$$
m_{D}=\Delta m_{\text {pote }}-m_{p d},
$$

onde, $m_{D}$ representa a massa perdida de pasta catalítica e $\Delta m_{\text {pote }}$ representa a diferença entre a massa inicial e final do pote de pasta catalítica no processo de Impressão à Tela.

$$
\% D=\left(\frac{m_{D}}{m_{p d}}\right) \times 100
$$

onde, $\% D$ representa o percentual de perda do processo. 
A comparação entre o percentual de perda dos três lotes e o conhecido do processo de Aspersão é apresentada na TAB.20.

TABELA 20 - Resultados da Estimativa de Perdas $\left(144 \mathrm{~cm}^{2}\right)$

\begin{tabular}{c|c|c|c|c|c}
\hline LOTE & $m_{e s}$ & $m_{p d}$ & $\Delta m_{p o t e}$ & $m_{D}$ & $\% D$ \\
\hline 1 & $4,182 \mathrm{~g}$ & $13,940 \mathrm{~g}$ & $51,158 \mathrm{~g}$ & $37,218 \mathrm{~g}$ & $267 \%$ \\
\hline 2 & $4,908 \mathrm{~g}$ & $16,360 \mathrm{~g}$ & $39,920 \mathrm{~g}$ & $23,560 \mathrm{~g}$ & $144 \%$ \\
\hline 3 & $1,737 \mathrm{~g}$ & $5,790 \mathrm{~g}$ & $16,134 \mathrm{~g}$ & $10,344 \mathrm{~g}$ & $179 \%$ \\
\hline \multicolumn{6}{c}{$\% D$} \\
\hline
\end{tabular}

O estudo da estimativa de perda comprova que o método de Impressão à Tela é mais adequado para produções por batelada, isto é, por lotes limitados. Isto porque o total de tinta perdida por contato com espátulas, luvas e na própria peneira cresce muito pouco quando aumentado o tamanho do lote. Assim quanto maior o lote menor a perda, porém o tamanho do lote fica limitado à capacidade dos operadores de gerenciar a secagem e o tratamento térmico das membranas. Desta maneira, não é recomendável o lote unitário porque gera muita perda e nem é possível a produção seriada em função das limitações do processo.

A produção por batelada é adequada para a construção de pequenos módulos de potência, até $10 \mathrm{~kW}$. O processo de Aspersão é mais adequado do que o método de Impressão à Tela se a finalidade for a de experimentos de pesquisa e desenvolvimento de eletrocatalisadores.

\subsection{Produção por um operador}

Os MEAs resultantes deste experimento foram prensados e posteriormente utilizados na comparação com MEAs comerciais e com outros produzidos por Aspersão.

$\mathrm{Na}$ TAB.21 são apresentados resultados deste estudo com o cálculo das massas depositadas de platina e de Nafion ${ }^{\circledR}$ para cada um dos eletrodos de cada MEA confeccionado. Na mesma tabela foi também apresentada a carga nominal de deposição. 
TABELA 21 - Resultados Produção por um operador $\left(144 \mathrm{~cm}^{2}\right)$

\begin{tabular}{|c|c|c|c|c|}
\hline \multirow[b]{2}{*}{ MEA } & \multicolumn{2}{|c|}{ Ânodo } & \multicolumn{2}{|c|}{ Cátodo } \\
\hline & $\begin{array}{c}\mathbf{P t} \\
\left(0,4 \mathrm{mg} \cdot \mathrm{cm}^{-2}\right)\end{array}$ & $\begin{array}{c}\text { Nafion }^{\circledR} \\
\left(1,08 \mathrm{mg} \cdot \mathrm{cm}^{-2}\right)\end{array}$ & $\begin{array}{c}\mathbf{P t} \\
\left(0,4 \mathrm{mg} \cdot \mathrm{cm}^{-2}\right)\end{array}$ & $\begin{array}{c}\text { Nafion }^{\circledR} \\
(1,08 \text { mg.cm } \\
\end{array}$ \\
\hline Sie144_03 & 0,316 & 0,851 & 0,457 & 1,230 \\
\hline Sie144_04 & 0,316 & 0,851 & 0,479 & 1,290 \\
\hline
\end{tabular}

Nenhuma etapa do processo apresentou dificuldade maior pelo fato de ser realizada por um operador, porém esta prática limita o tamanho do lote ou pelo menos aumenta o tempo de produção por utilizar menos recursos humanos. A produção por uma pessoa só foi possível devido à aplicação da regra de deposição (ver item 5.10).

\subsection{Desempenho $144 \mathrm{~cm}^{2}$ - Impressão à Tela vs Aspersão vs Comercial}

Os MEAs utilizados neste experimento são apresentados na TAB.22 juntamente com as cargas de Pt e Nafion ${ }^{\circledR}$ calculadas por eletrodo.

TABELA 22 - Cargas calculadas $\left(144 \mathrm{~cm}^{2}\right)$

\begin{tabular}{|c|c|c|c|c|c|}
\hline \multirow[b]{2}{*}{ MEIO } & \multirow[b]{2}{*}{ MEA } & \multicolumn{2}{|c|}{ Ânodo } & \multicolumn{2}{|c|}{ Cátodo } \\
\hline & & $\begin{array}{c}\mathbf{P t} \\
\left(0,4 \mathrm{mg} \cdot \mathrm{cm}^{-2}\right)\end{array}$ & $\begin{array}{c}\text { Nafion }^{\circledR} \\
(1,08 \text { mg.cm } \\
\end{array}$ & $\begin{array}{c}\mathbf{P t} \\
\left(0,6 \mathrm{mg} \cdot \mathrm{cm}^{-2}\right)\end{array}$ & $\begin{array}{c}\text { Nafion }^{\circledR} \\
(1,62 \text { mg.cm } \\
\text { (2) }\end{array}$ \\
\hline \multirow{2}{*}{ Aspersão } & Spr144_01 & 0,438 & 1,179 & 0,609 & 1,640 \\
\hline & Spr144_02 & 0,403 & 1,085 & 0,596 & 1,605 \\
\hline \multirow{5}{*}{$\begin{array}{l}\text { Impressão } \\
\text { à Tela }\end{array}$} & Sie144_01 & 0,421 & 1,133 & 0,469 & 1,263 \\
\hline & Sie144_02 & 0,458 & 1,233 & 0,485 & 1,306 \\
\hline & Sie144_03 & 0,316 & 0,851 & 0,457 & 1,230 \\
\hline & Sie144_05 & 0,410 & 1,103 & 0,409 & 1,101 \\
\hline & Sie144_06 & 0,394 & 1,060 & 0,424 & 1,142 \\
\hline \multirow{2}{*}{ ETEK } & ETEK_01 & 0,400 & - & 0,400 & - \\
\hline & ETEK_02 & 0,400 & - & 0,400 & - \\
\hline
\end{tabular}

Percebeu-se que, no início da operação, todos os MEAs apresentaram melhores resultados ao trabalhar em temperaturas inferiores a $65^{\circ} \mathrm{C}$. Com a continuação das operações, os MEAs Spr144_01, Spr144_02, ETEK_01 e ETEK_02 obtiveram o melhor desempenho em torno de $73^{\circ} \mathrm{C}$. Os demais conjuntos apresentaram melhores resultados em torno de $65^{\circ} \mathrm{C}$. 
O MEA Sie144_02 falhou durante a operação. Percebeu-se uma queda brusca de desempenho e a operação foi interrompida. Quando a célula foi aberta o conjunto estava descolado e apresentava dois rasgos na membrana.

Comportamento similar foi apresentado para o MEA ETEK_02. Este conjunto (comercial) apresentou fissura na membrana lateralmente ao eletrodo, porém dentro do perímetro de vedação. Assim, os gases (hidrogênio e oxigênio) entraram em contato direto e por este fato o desempenho da célula foi prejudicado impossibilitando a realização das curvas de polarização e de potência.

Os MEAs confeccionados foram comparados no ponto de potencial de operação (em torno de $600 \mathrm{mV}$ ) de suas melhores curvas, como apresentado na TAB.23.

TABELA 23 - Resultados no Potencial de Operação $\left(144 \mathrm{~cm}^{2}\right)$

\begin{tabular}{|c|c|c|c|c|c|c|}
\hline \multirow[b]{2}{*}{ PONTO } & \multirow{2}{*}{$\begin{array}{c}\text { MEA } \\
\text { (curva) }\end{array}$} & \multicolumn{5}{|c|}{ RESULTADOS OBTIDOS } \\
\hline & & $\begin{array}{c}\text { I } \\
\text { (A) }\end{array}$ & $\begin{array}{c}i \\
\left(\mathrm{~mA} \cdot \mathrm{cm}^{-2}\right)\end{array}$ & $\begin{array}{c}E \\
(\mathrm{mV})\end{array}$ & $\begin{array}{c}P \\
(W)\end{array}$ & $\begin{array}{c}p \\
\left(\mathrm{~mW} \cdot \mathrm{cm}^{-2}\right)\end{array}$ \\
\hline \multirow{9}{*}{$E_{\text {ope }}$} & Spr144_01b & 24,0 & 166,67 & 596 & 14,30 & 99,33 \\
\hline & Spr144_02c & 32,0 & 222,22 & 604 & 19,33 & 134,22 \\
\hline & Sie144_01b & 22,0 & 152,78 & 607 & 13,35 & 92,74 \\
\hline & Sie144_02 & 25,0 & 173,61 & 600 & 15,00 & 104,17 \\
\hline & Sie144_03c & 30,0 & 208,33 & 591 & 17,73 & 123,13 \\
\hline & Sie144_05b & 43,0 & 298,61 & 599 & 25,76 & 178,87 \\
\hline & Sie144_06a & 45,0 & 312,50 & 600 & 27,00 & 187,50 \\
\hline & ETEK_01c & 54,0 & 375,00 & 601 & 32,45 & 225,38 \\
\hline & ETEK_02 & 35,3 & 245,14 & 601 & 21,22 & 147,33 \\
\hline
\end{tabular}

Nota: Não foram realizadas curvas para os MEAs Sie144_02 e ETEK_02. Os dois furaram durante a operação.

O tempo médio de ativação da maioria dos MEAs foi maior que uma semana (50 horas), sendo que a rotina de operação variou de oito a doze horas diária. Somente os MEAs Sie144_05 e Sie144_06 atingiram seus melhores resultados após oito horas de ativação apenas. Esta diferença no tempo de ativação dos conjuntos de $144 \mathrm{~cm}^{2}$ de área ativa confeccionados neste trabalho provavelmente está relacionada com as mudanças implementadas, 
principalmente a realização da montagem em célula com o conjunto ainda quente, retirado diretamente da mesa da prensa.

O projeto da célula unitária demonstrou-se capaz de produzir resultados maiores que $300 \mathrm{~mA} . \mathrm{cm}^{-2}$ para $600 \mathrm{mV}$, conforme observado na TAB.23. Um bom desempenho quando comparado a outras células similares $-220 \mathrm{~mA} \cdot \mathrm{cm}^{-2}$ a $600 \mathrm{mV}$ com área ativa de $127,50 \mathrm{~cm}^{2}$ e MEA com cargas de 0,5:0,5 mgPt.cm ${ }^{-2}$ nos eletrodos /SAR03/.

No experimento de desempenho de MEAs de $144 \mathrm{~cm}^{2}$ somente os MEAs comerciais e os conjuntos produzidos por Impressão à Tela e prensados entre placas de $15,1 \mathrm{~cm}$ de comprimento por 15,1 cm largura não descolaram durante a operação e atingiram os melhores desempenhos a $600 \mathrm{mV}$, acima de $300 \mathrm{~mA} \cdot \mathrm{cm}^{-2}$. Os demais conjuntos, prensados entre placas de $12 \mathrm{~cm}$ de comprimento por $12 \mathrm{~cm}$ largura, descolaram após algum tempo de operação, este fato mostra a importância da adequação do processo de prensagem a quente no desempenho em célula. A queda no desempenho é percebida na FIG.30, que apresenta as melhores curvas dos MEAs de $144 \mathrm{~cm}^{2}$ de área ativa confeccionados por Impressão à Tela.

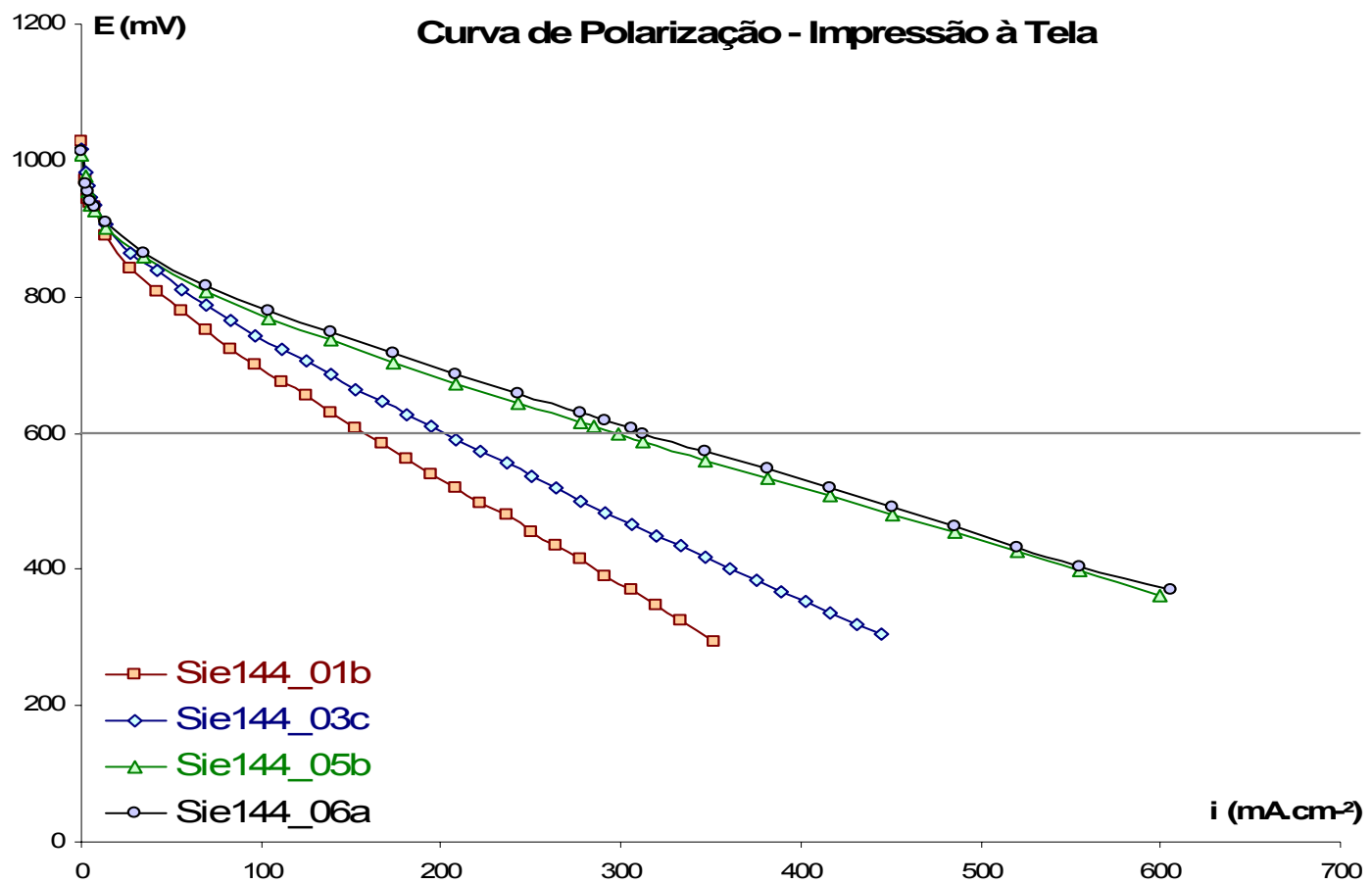

FIGURA 30- Curvas de Polarização dos MEAs $\left(144 \mathrm{~cm}^{2}\right)$ confeccionados por Impressão à Tela. Operação com $\mathrm{H}_{2} / \mathrm{O}_{2}$ puros. Umidificação no ânodo $\left(90^{\circ} \mathrm{C}\right)$ e no cátodo $\left(80^{\circ} \mathrm{C}\right)$. Vazões de 1,0 L.min ${ }^{-1}$. Temperatura de célula mantida em torno de $65^{\circ} \mathrm{C}$. 
$\mathrm{Na}$ FIG.30, os MEAs prensados entre placas de $(12 \times 12) \mathrm{cm}^{2}$, Sie144_01 e Sie144_03, apresentam altos valores de resistência em suas curvas, $1551 \mathrm{~m} \Omega . \mathrm{cm}^{2}$ e $1254 \Omega . \mathrm{cm}^{2}$, respectivamente. Os conjuntos Sie144_05 e Sie144_06, prensados entre placas de $(15,1 \times 15,1) \mathrm{cm}^{2}$, obtiveram, na região de predominância de polarização por queda ôhmica, menores coeficientes angulares da reta, apresentando menores resistências, $844 \mathrm{~m} \Omega . \mathrm{cm}^{2}$ para Sie144_05 e Sie144_06 com $810 \mathrm{~m} \Omega . \mathrm{cm}^{2}$.

Estes resultados demonstram que o uso das placas de maior dimensão melhorou o resultado da prensagem a quente. Esta melhoria da prensagem a quente surtiu efeito benéfico no desempenho com a obtenção de um aumento maior do que $104 \%$ na densidade de corrente entre o pior e o melhor resultado a $600 \mathrm{mV}$ para os conjuntos confeccionados por Impressão à Tela.

$\mathrm{Na}$ FIG.31 são apresentadas curvas de polarização dos MEAs fabricados por Aspersão e utilizados neste estudo.

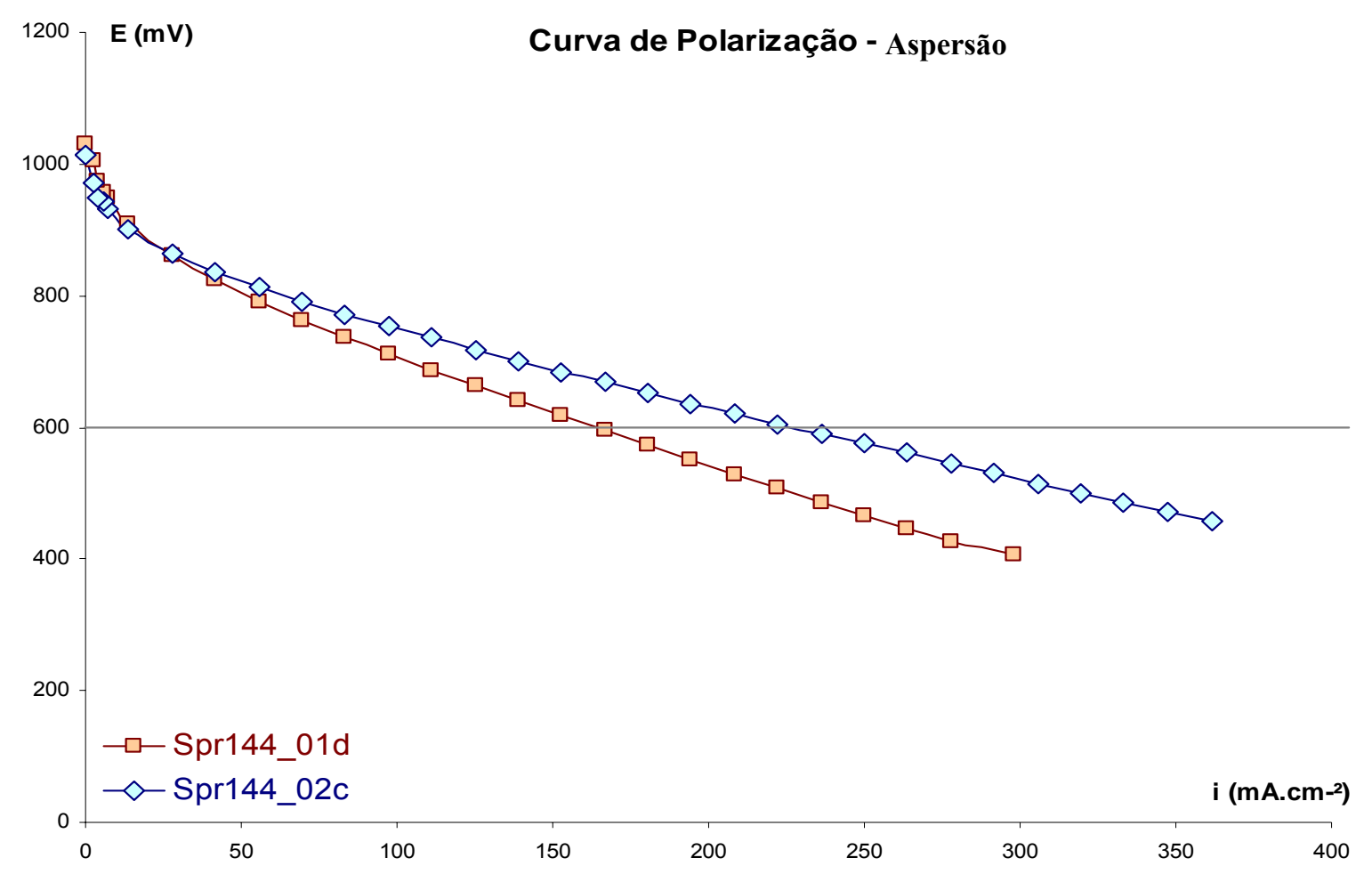

FIGURA 31 - Curvas de Polarização dos MEAs $\left(144 \mathrm{~cm}^{2}\right)$ confeccionados por Aspersão. Operação com $\mathrm{H}_{2} / \mathrm{O}_{2}$ puros. Umidificação no ânodo $\left(90^{\circ} \mathrm{C}\right)$ e no cátodo $\left(80^{\circ} \mathrm{C}\right)$. Vazões de 1,0 L. $\mathrm{min}^{-1}$. Temperatura de célula mantida em torno de $73^{\circ} \mathrm{C}$. 
As resistências obtidas através das curvas apresentadas na FIG.31 ficaram acima de $1000 \mathrm{~m} \Omega \cdot \mathrm{cm}^{2}$, com o conjunto Spr144_01 em sua curva "d" obtendo $1561 \mathrm{~m} \Omega . \mathrm{cm}^{2}$ e o MEA Spr144_02 alcançando $1101 \mathrm{~m} \Omega . \mathrm{cm}^{2}$. Ambos foram prensados entre placas de $(12 \times 12) \mathrm{cm}^{2}$ e produzidos com maior carga de $\mathrm{Pt}$ no cátodo que os demais MEAs do experimento de $144 \mathrm{~cm}^{2}$, constituindo conjuntos de 0,4:0,6 mgPt.cm ${ }^{-2}$. Neste caso, o baixo desempenho não pode ser atribuído somente ao processo de prensagem a quente. Durante a confecção destes MEAs por Aspersão diversos problemas ocorreram causados principalmente pelo não alcance da temperatura ideal da mesa de vácuo para o processo de pintura.

A comparação entre o melhor MEA produzido por cada processo e o comercial da ETEK é realizada na FIG.32.

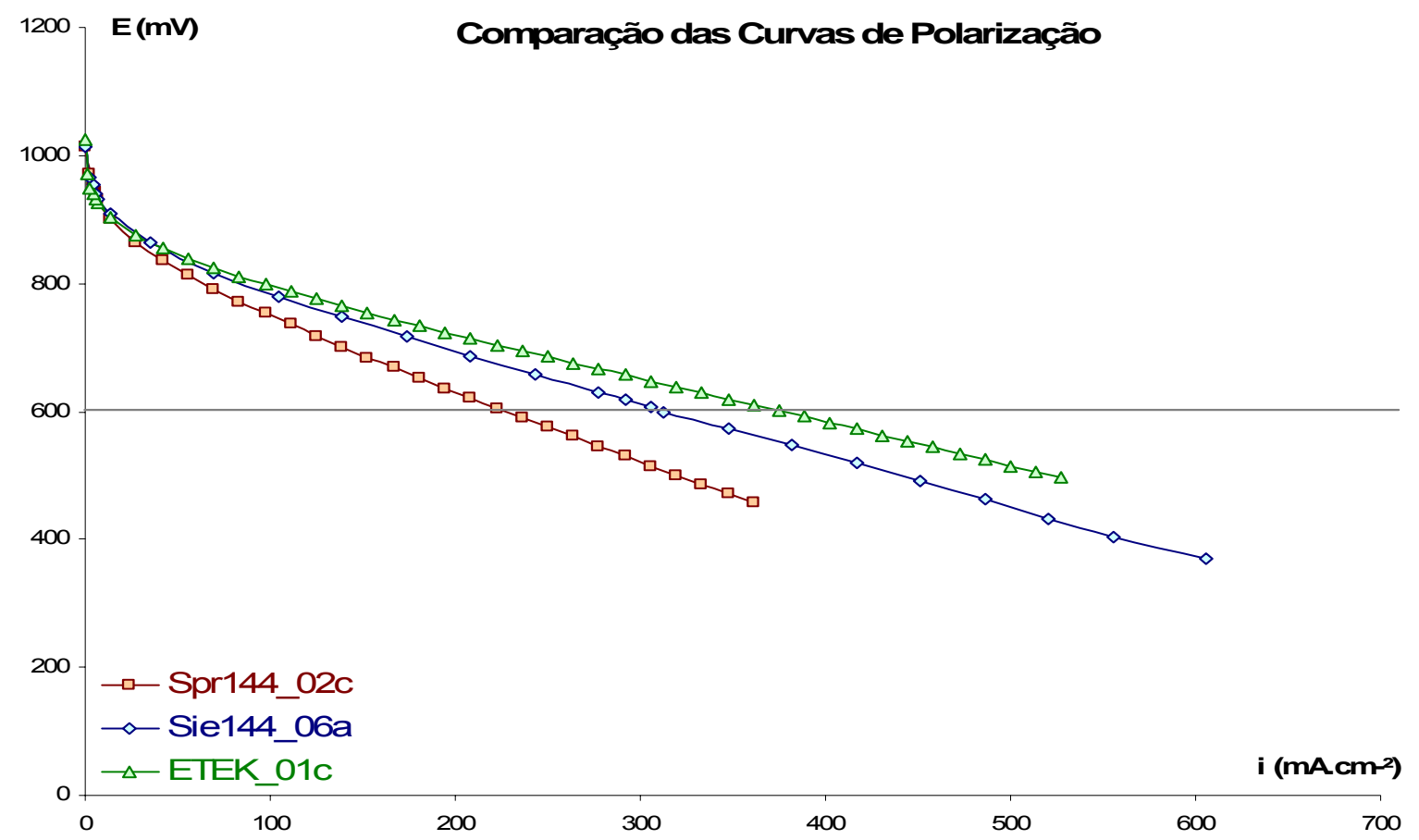

FIGURA 32- Curvas de Polarização dos melhores MEAs $\left(144 \mathrm{~cm}^{2}\right)$, Aspersão, Impressão à Tela e o comercial da E-TEK. Operação com $\mathrm{H}_{2} / \mathrm{O}_{2}$ puros. Umidificação no ânodo $\left(90^{\circ} \mathrm{C}\right)$ e no cátodo $\left(80^{\circ} \mathrm{C}\right)$. Vazões de $1,0 \mathrm{~L}$. $\mathrm{min}^{-1}$. Temperatura de célula mantida entre $65^{\circ} \mathrm{C}$ e $73^{\circ} \mathrm{C}$.

$\mathrm{Na}$ FIG.32 são percebidas as diferentes inclinações das curvas apresentadas pelos três conjuntos comparados. Maior diferença é verificada entre as curvas ETEK_01c (conjunto comercial) e Spr144_02C (conjunto confeccionado por Aspersão). O MEA comercial (ETEK) apresentou os melhores resultados, resistência de $683 \mathrm{~m} \Omega . \mathrm{cm}^{2}$ e densidade de corrente de $375 \mathrm{~mA} \cdot \mathrm{cm}^{-2}$ a $600 \mathrm{mV}$. 
Os conjuntos comerciais apresentavam camada difusora ELAT dos dois lados do tecido de carbono enquanto os MEAs produzidos neste estudo utilizaram tecido de carbono com $30 \%$ de Teflon $^{\circledR}$. Estas características, associadas ao processo de prensagem ineficiente, utilizando placas de $(12 \times 12) \mathrm{cm}^{2}$, podem ter sido responsáveis pelas maiores diferenças de desempenho entre as curvas mostradas nas FIG.30 a 32.

Os MEAs também foram comparados nos pontos de potência máxima de suas melhores curvas (TAB.24).

TABELA 24 - Resultados na Potência Máxima $\left(144 \mathrm{~cm}^{2}\right)$

\begin{tabular}{|c|c|c|c|c|c|c|}
\hline \multirow[b]{2}{*}{ PONTO } & \multirow{2}{*}{$\begin{array}{c}\text { MEA } \\
\text { (curva) }\end{array}$} & \multicolumn{5}{|c|}{ RESULTADOS OBTIDOS } \\
\hline & & $\begin{array}{c}\text { I } \\
\text { (A) }\end{array}$ & $\begin{array}{c}\text { i } \\
\left(\mathrm{mA} \cdot \mathrm{cm}^{-2}\right)\end{array}$ & $\begin{array}{c}E \\
(\mathrm{mV})\end{array}$ & $\begin{array}{c}P \\
(W)\end{array}$ & $\begin{array}{c}P \\
\left(\mathrm{~mW} \cdot \mathrm{cm}^{-2}\right)\end{array}$ \\
\hline \multirow{9}{*}{$P_{\text {máx }}$} & Spr144_01b & 42,90 & 297,91 & 408 & 17,50 & 121,55 \\
\hline & Spr144_02c & 52,10 & 361,81 & 458 & 23,86 & 165,57 \\
\hline & Sie144_01b & 40,00 & 277,78 & 414 & 16,56 & 115,00 \\
\hline & Sie144_02 & \multicolumn{5}{|c|}{ Dados não levantados para este MEA } \\
\hline & Sie144_03c & 50,00 & 347,22 & 419 & 20,95 & 145,49 \\
\hline & Sie144_05b & 75,00 & 520,83 & 427 & 32,03 & 222,40 \\
\hline & Sie144_06a & 75,00 & 520,83 & 433 & 32,48 & 225,52 \\
\hline & ETEK_01c & 76,00 & 527,78 & 497 & 37,77 & 262,31 \\
\hline & ETEK_02 & \multicolumn{5}{|c|}{ Dados não levantados para este MEA } \\
\hline
\end{tabular}

Todos os resultados de pico de potência apresentados na TAB.24 foram alcançados em valores de potencial e densidade de corrente que correspondem à região de queda ôhmica nas curvas de polarização.

Os MEAs Sie144_05, Sie144_06 e ETEK_01 apresentaram densidade de potência máxima superior a $220 \mathrm{~mW} . \mathrm{cm}^{-2}$, e o maior pico foi registrado para a curva ETEK_01c em 262,31 mW.cm ${ }^{-2}$ a $497 \mathrm{mV}$. Todos os conjuntos prensados entre placas de $12 \mathrm{~cm}$ de largura por $12 \mathrm{~cm}$ de comprimento apresentaram densidades de potência abaixo de $170 \mathrm{~mW} . \mathrm{cm}^{-2}$.

As melhorias implementadas no processo de prensagem a quente provavelmente foram responsáveis pelo aumento de até $96 \%$ no valor da densidade de potência máxima entre os conjuntos fabricados por Impressão à Tela. 
As melhores curvas de potência dos MEAs confeccionados por Aspersão e por Impressão à Tela são comparadas na FIG.33 com o conjunto comercial da ETEK.

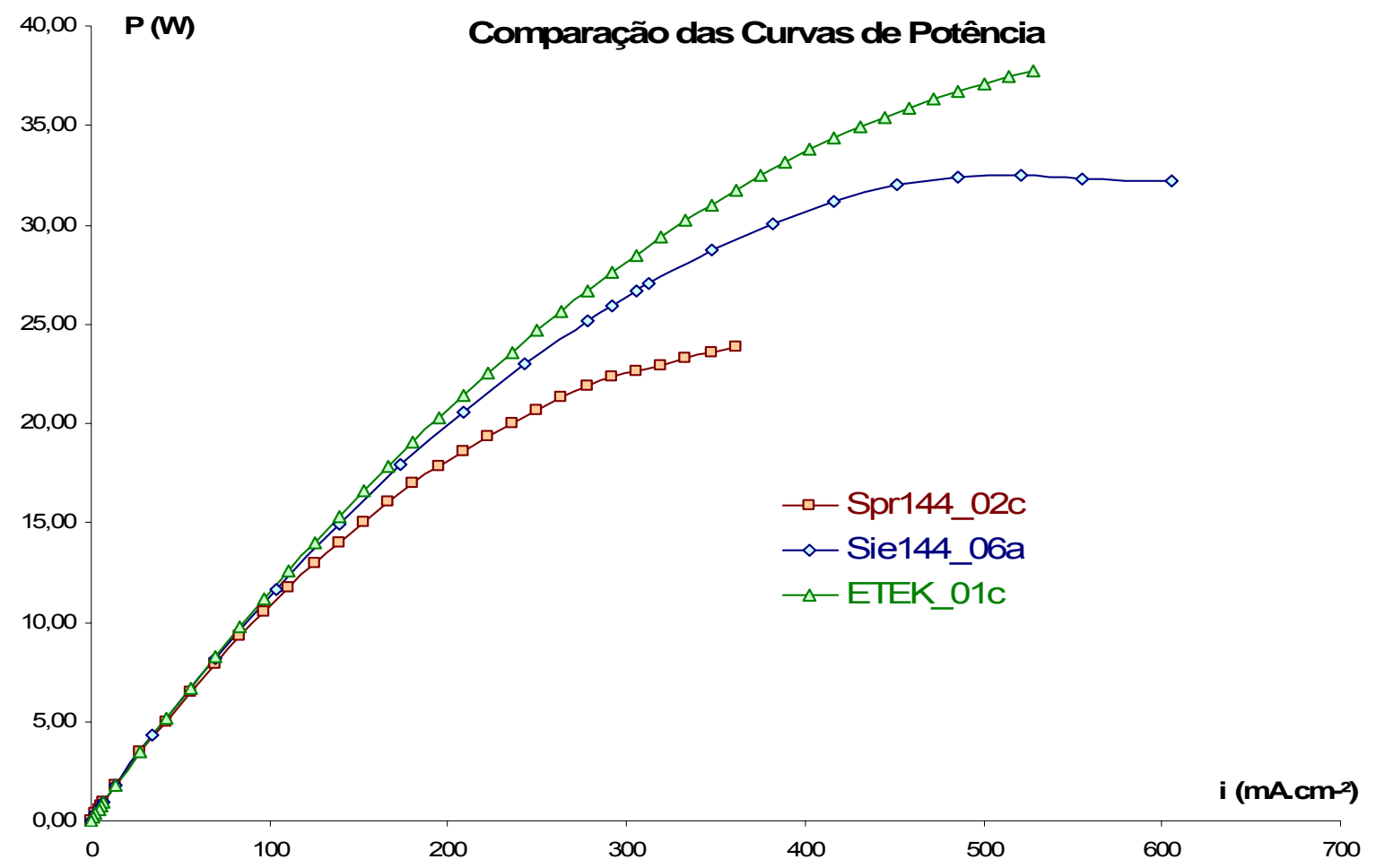

FIGURA 33- Curvas de Potência dos melhores MEAs $\left(144 \mathrm{~cm}^{2}\right)$, Aspersão, Impressão à Tela e o comercial da E-TEK. Operação com $\mathrm{H}_{2} / \mathrm{O}_{2}$ puros. Umidificação no ânodo $\left(90^{\circ} \mathrm{C}\right)$ e no cátodo $\left(80^{\circ} \mathrm{C}\right)$. Vazões de 1,0 L. $\min ^{-1}$. Temperatura de célula mantida entre $65^{\circ} \mathrm{C}$ e $73^{\circ} \mathrm{C}$.

O descolamento da curva Spr144_02c na FIG.33 é percebido mesmo abaixo de $100 \mathrm{~mA} \cdot \mathrm{cm}^{-2}$. O MEA comercial, ETEK_01, apresentou melhores resultados ao longo de toda a curva de potência em relação aos demais. $O$ conjunto Sie144_06 apresentou desempenho mais próximo do comercial, porém isto só foi possível após emprego da prensagem a quente entre placas de alumínio de $(15,1 \times 15,1) \mathrm{cm}^{2}$ nos MEAs fabricados por Impressão à Tela.

Nesta comparação de desempenho, dois MEAs de $144 \mathrm{~cm}^{2}$ de área ativa confeccionados no laboratório e prensados entre placas de $(12 \times 12) \mathrm{cm}^{2}$ apresentaram comportamento similar a $600 \mathrm{mV}$. Conforme TAB.23, o conjunto Spr144_02 confeccionado por Aspersão alcançou 222,22 mA.cm ${ }^{-2}$ e o MEA Sie144_03 produzido por Impressão à Tela registrou 208,33 mA.cm ${ }^{-2}$. Porém deve-se ressaltar que os MEAs produzidos por Aspersão tinham uma carga maior, 0,4:0,6 mgPt.cm ${ }^{-2}$, enquanto que os conjuntos de Impressão à Tela foram 
produzidos com carga de 0,4:0,4 mgPt.cm ${ }^{-2}$, neste caso, significa que o processo de Impressão à Tela conseguiu conferir aos MEAs um melhor desempenho.

Porém, as maiores diferenças em desempenho foram percebidas entre conjuntos fabricados pelo mesmo processo de deposição de eletrodo e prensados entre placas de diferentes dimensões. Os MEAs prensados entre placas de maiores dimensões apresentaram melhores resultados a $600 \mathrm{mV}$ e no pico de potência, além de alcançarem os menores valores de resistência. Este fato reforça a influência do processo de prensagem a quente no desempenho do MEA. A inadequação deste processo, utilizando placas de $(12 \times 12) \mathrm{cm}^{2}$, é muito provavelmente uma das causadoras da maior resistência em conjuntos eletrodosmembrana registrada neste experimento, de $1551 \mathrm{~m} \Omega . \mathrm{cm}^{2}$ para o MEA Sie144_01.

Um processo que não foi abordado neste trabalho, porém passível de execução em estudos futuros é a pintura sobre tecido de carbono. Este processo pode ser implementado tanto para deposição de camada catalítica como para deposição de camada difusora (similar ao ELAT). Além disso, outros trabalhos futuros poderiam abordar a variação da composição, o emprego de um tecido de carbono com outros percentuais de Teflon $^{\circledR}$ e a deposição de menores cargas de componentes nobres. Estas situações podem colaborar para a redução do custo do conjunto eletrodo-membrana-eletrodo, além de melhorar o desempenho em operação.

\subsection{Custo da Célula Unitária de $144 \mathrm{~cm}^{2}$ de área ativa}

Para a construção da célula unitária de $144 \mathrm{~cm}^{2}$ de área ativa segundo o projeto desenvolvido neste trabalho foram empregados diversos materiais. Além disso, alguns serviços tiveram que ser contratados para que a célula atendesse às especificações de projeto. Para levantar o custo de fabricação deste dispositivo foi realizado levantamento de preços junto às ordens de compra emitidas aos fornecedores utilizados na construção da célula.

Os materiais comprados, suas quantidades e unidades, bem como os respectivos valores em reais, são apresentados na TAB.25. 
TABELA 25 - Custo dos Materiais da Célula Unitária

\begin{tabular}{c|c|c|c|c}
\hline ITEM & ESPEC & QUANT & UNIT & TOTAL \\
\hline $\begin{array}{c}\text { Placa de } \\
\text { Grafite }\end{array}$ & $\begin{array}{c}187 \times 187 \times 4 \mathrm{~mm} \\
\text { (impregnada) }\end{array}$ & 4 unidades & 52,00 & 208,00 \\
\hline $\begin{array}{c}\text { Placa de } \\
\text { Cobre }\end{array}$ & $187 \times 200 \times 1 \mathrm{~mm}$ & 4 unidades & 28,00 & 112,00 \\
\hline $\begin{array}{c}\text { Placa de } \\
\text { Alumínio }\end{array}$ & $187 \times 187 \times 10 \mathrm{~mm}$ & 4 unidades & 30,00 & 120,00 \\
\hline Vedação & O-ring de Viton ${ }^{\circledR}$ & $6,00 \mathrm{~m}$ & 16,00 & 96,00 \\
\hline Fixação & Parafusos e porcas & 32 conjuntos & 0,00 & 0,00 \\
\hline Fixação & Buchas de Teflon & \\
\hline Conexão & $\begin{array}{c}\text { Engate rápido para tubo } \\
\text { de } \varnothing 6 \text { mm }\end{array}$ & 84 unidades & 4,38 & 280,32 \\
\hline $\begin{array}{c}\text { Resistência } \\
\text { Elétrica }\end{array}$ & $\begin{array}{r}\varnothing 6,35 \times 120 \mathrm{~mm} ; 60 \mathrm{~W} \text { e } \\
110 \mathrm{~V}\end{array}$ & 12 unidades & 42,00 & 504,00 \\
\hline
\end{tabular}

O custo de cada serviço contratado é mostrado na TAB.26.

TABELA 26 - Custo dos Serviços realizados na Célula Unitária

\begin{tabular}{c|c|c|c|c}
\hline ITEM & ESPEC & QUANT & UNIT & TOTAL \\
\hline Usinagem de Grafite & Rasgos e furações & 4 unidades & 177,00 & 708,00 \\
\hline $\begin{array}{c}\text { Usinagem de Cobre } \\
\text { e Alumínio }\end{array}$ & Rasgos e furações & 8 unidades & 50,00 & 400,00 \\
\hline Douração do Cobre & Dois lados & 4 unidades & 230,00 & 920,00 \\
\hline
\end{tabular}

As quantidades apresentadas referem-se àquelas necessárias para a construção de dois conjuntos de célula unitária. O custo da construção de um conjunto de célula unitária $\left(144 \mathrm{~cm}^{2}\right)$ girou em torno de $\mathrm{R} \$ 1.700,00$. Durante os experimentos realizados neste trabalho, percebeu-se que o sistema de aquecimento projetado era desnecessário, assim, com a eliminação do custo das resistências elétricas, cada conjunto de placas da célula unitária custa em média $\mathrm{R} \$ 1.450,00$.

\subsection{Custo de Produção do MEA de $144 \mathrm{~cm}^{2}$ por Impressão à Tela}

A caracterização do MEA e dos lotes estudados é apresentada na

TAB.27. Esta tabela foi construída considerando uma carga total de $0,8 \mathrm{mgPt} . \mathrm{cm}^{-2}$ 
por MEA e uma composição de eletrodo com $35 \%$ de Nafion ${ }^{\circledR}$ seco. Os valores são apresentados em gramas para uma área ativa de $144 \mathrm{~cm}^{2}$.

TABELA 27 - Estimativa de custo (Spr - Aspersão; Sie - Impressão à Tela)

\begin{tabular}{c|c|c|c|c|c|c}
\hline \multirow{2}{*}{ QUANT } & \multirow{2}{*}{ PROC } & \multicolumn{2}{|c|}{ ELETROCATALISADOR } & \multirow{2}{*}{ NAFION } & \multirow{2}{*}{$m_{e s}$} \\
\cline { 3 - 5 } & & $P t$ & $C$ & Total & & \multirow{2}{*}{$0,310 \mathrm{~g}$} \\
\hline 1 & Spr & $0,115 \mathrm{~g}$ & $0,461 \mathrm{~g}$ & $0,576 \mathrm{~g}$ & $0,386 \mathrm{~g}$ \\
\hline 2 & Sie & $0,230 \mathrm{~g}$ & $0,922 \mathrm{~g}$ & $1,152 \mathrm{~g}$ & $0,620 \mathrm{~g}$ & $1,772 \mathrm{~g}$ \\
\hline 4 & Sie & $0,461 \mathrm{~g}$ & $1,843 \mathrm{~g}$ & $2,304 \mathrm{~g}$ & $1,241 \mathrm{~g}$ & $3,545 \mathrm{~g}$ \\
\hline 6 & Sie & $0,691 \mathrm{~g}$ & $2,765 \mathrm{~g}$ & $3,456 \mathrm{~g}$ & $1,861 \mathrm{~g}$ & $5,317 \mathrm{~g}$ \\
\hline 8 & Sie & $0,922 \mathrm{~g}$ & $3,686 \mathrm{~g}$ & $4,608 \mathrm{~g}$ & $2,481 \mathrm{~g}$ & $7,089 \mathrm{~g}$ \\
\hline
\end{tabular}

A massa do eletrodo seco $\left(m_{e s}=\right.$ Nafion $^{\circledR}+$ eletrocatalisador $)$ foi calculada para servir de base para o estudo de levantamento de custo.

O levantamento de custo foi realizado para os componentes da pasta catalítica, para o tecido de carbono empregado e para a membrana utilizada. Para os componentes da pasta catalítica foram considerados o percentuais de perda, $\% D$, calculados no item 5.10 deste trabalho e feita uma projeção para lotes com seis e oito MEAs. O percentual de sólidos da pasta quando da deposição foi definido como $30 \%$. Assim é possível calcular a massa da pasta depositada $\left(m_{p d}\right)$, a massa desperdiçada $\left(m_{D}\right)$ e a massa total de pasta a ser produzida para a confecção do lote $\left(m_{T}\right)$. Na TAB.28 as massas são apresentadas em gramas e \%D em percentagem.

TABELA 28 - Cálculo da massa total de pasta produzida

\begin{tabular}{c|c|c|c|c|c|c}
\hline QUANT & PROC & $m_{e s}$ & $m_{p d}$ & $\% D$ & $m_{D}$ & $m_{T}$ \\
\hline 1 & Spr & $0,886 \mathrm{~g}$ & $2,953 \mathrm{~g}$ & $100 \%$ & $2,953 \mathrm{~g}$ & $5,906 \mathrm{~g}$ \\
\hline 2 & Sie & $1,772 \mathrm{~g}$ & $5,907 \mathrm{~g}$ & $179 \%$ & $10,553 \mathrm{~g}$ & $16,460 \mathrm{~g}$ \\
\hline 4 & Sie & $3,545 \mathrm{~g}$ & $11,817 \mathrm{~g}$ & $144 \%$ & $17,018 \mathrm{~g}$ & $28,835 \mathrm{~g}$ \\
\hline 6 & Sie & $5,317 \mathrm{~g}$ & $17,723 \mathrm{~g}$ & $116 \%$ & $20,575 \mathrm{~g}$ & $38,298 \mathrm{~g}$ \\
\hline 8 & Sie & $7,089 \mathrm{~g}$ & $23,630 \mathrm{~g}$ & $94 \%$ & $22,113 \mathrm{~g}$ & $45,743 \mathrm{~g}$ \\
\hline
\end{tabular}

$\mathrm{Na}$ TAB.28 os $\% D$ dos lotes com seis e com oito MEAs foram projetados usando a relação entre os percentuais de perda medidos dos lotes com quatro e dois MEAs (aproximadamente 80\%). Experimentos futuros com estes tamanhos de lotes poderão estimar o $\% D$ com maior precisão, de qualquer 
forma eles foram considerados aqui para que seja possível visualizar o efeito do aumento do lote no custo unitário do MEA.

Com o conhecimento da massa total de pasta catalítica a ser produzida para a confecção de cada lote, pode-se descobrir a massa de cada componente sólido da pasta. Valores em gramas são apresentados na TAB.29.

TABELA 29 - Cálculo dos componentes sólidos

\begin{tabular}{c|c|c|c|c|c}
\hline QUANT & PROC & $m_{T}$ & Sólidos & Eletrocat. & Nafion $^{\circledR}$ \\
\hline 1 & Spr & $5,906 \mathrm{~g}$ & $1,772 \mathrm{~g}$ & $1,152 \mathrm{~g}$ & $0,620 \mathrm{~g}$ \\
\hline 2 & Sie & $16,460 \mathrm{~g}$ & $4,938 \mathrm{~g}$ & $3,210 \mathrm{~g}$ & $1,728 \mathrm{~g}$ \\
\hline 4 & Sie & $28,835 \mathrm{~g}$ & $8,651 \mathrm{~g}$ & $5,623 \mathrm{~g}$ & $3,028 \mathrm{~g}$ \\
\hline 6 & Sie & $38,298 \mathrm{~g}$ & $11,489 \mathrm{~g}$ & $7,468 \mathrm{~g}$ & $4,021 \mathrm{~g}$ \\
\hline 8 & Sie & $45,743 \mathrm{~g}$ & $13,723 \mathrm{~g}$ & $8,920 \mathrm{~g}$ & $4,803 \mathrm{~g}$ \\
\hline
\end{tabular}

A coluna Nafion ${ }^{\circledR}$ da TAB.29 representa a massa deste ionômero na pasta sem considerar a massa do solvente existente na solução empregada para a produção da tinta catalítica. Os dados da TAB.29 foram aproveitados para o cálculo do quadro de massas por lote apresentado na TAB.31. O cálculo da massa de solução de Nafion ${ }^{\circledR}$ empregada na pasta é apresentado na TAB.30.

Para o cálculo dos componentes líquidos foi utilizada a composição da melhor pasta produzida como referência de proporção. Os valores assumidos são aqueles levantados antes do processo de evaporação e as densidades foram consideradas iguais a da água. Vide TAB.30.

TABELA 30 - Componentes da pasta catalítica de referência

\begin{tabular}{c|c|c|c|c|c}
\hline \multicolumn{2}{c|}{ Eletrocatalisador } & \multicolumn{2}{c}{ Solução de Nafion ${ }^{\circledR} \mathbf{5}$ vol.\% } & \multicolumn{2}{c}{ Solução 2:1 } \\
\hline \multicolumn{2}{c|}{$10,00 \mathrm{~g}$} & \multicolumn{2}{c|}{$108,00 \mathrm{~g}$} & \multicolumn{2}{c}{$30,00 \mathrm{~g}$} \\
\hline \multicolumn{2}{c|}{$6,76 \%$} & Nafion $^{\circledR}$ & Solventes & Água & $\mathbf{2 E E A}$ \\
\hline $\mathbf{P t}$ & $\mathrm{C}$ & $5,40 \mathrm{~g}$ & $102,60 \mathrm{~g}$ & $20,00 \mathrm{~g}$ & $10,00 \mathrm{~g}$ \\
\hline $2,00 \mathrm{~g}$ & $8,00 \mathrm{~g}$ & $3,65 \%$ & $69,32 \%$ & $13,51 \%$ & $6,76 \%$ \\
\hline $1,35 \%$ & $5,41 \%$ & Percentual de Líquidos na Pasta \\
\hline \multicolumn{3}{c|}{ Percentual de Sólidos na Pasta } & \multicolumn{3}{c}{$89,59 \%$} \\
\hline \multicolumn{3}{c}{$10,41 \%$} \\
\hline
\end{tabular}


Na TAB.31 é apresentado o resultado final do cálculo de massas (em gramas) dos componentes por lote de MEA produzido. O lote com um MEA produzido pelo processo de Aspersão (Spr) não recebe adição de 2EEA. O total de água utilizada foi suprimido por não interferir significativamente no cálculo do custo da pasta.

TABELA 31 - Quadro de massas por lote

\begin{tabular}{c|c|c|c|c}
\hline QUANT & PROC & Eletrocat. & Sol. Nafion $^{\circledR}$ & 2EEA \\
\hline 1 & $\mathrm{Spr}$ & $1,152 \mathrm{~g}$ & $12,400 \mathrm{~g}$ & $0,000 \mathrm{~g}$ \\
\hline 2 & $\mathrm{Sie}$ & $3,210 \mathrm{~g}$ & $34,560 \mathrm{~g}$ & $3,210 \mathrm{~g}$ \\
\hline 4 & $\mathrm{Sie}$ & $5,623 \mathrm{~g}$ & $60,560 \mathrm{~g}$ & $5,623 \mathrm{~g}$ \\
\hline 6 & Sie & $7,468 \mathrm{~g}$ & $80,420 \mathrm{~g}$ & $7,468 \mathrm{~g}$ \\
\hline 8 & Sie & $8,920 \mathrm{~g}$ & $96,060 \mathrm{~g}$ & $8,920 \mathrm{~g}$ \\
\hline
\end{tabular}

A massa do componente, apresentada na TAB.31, multiplicada pelo seu custo unitário representa o custo estimado total do componente no processo de fabricação. O custo unitário do componente é apresentado em dólares por grama e foi levantado a partir das ordens de compra realizadas pelo laboratório para aquisição destes materiais.

O somatório dos custos estimados dos componentes representa o custo da pasta catalítica (U\$MEA) e é apresentado na TAB.32 para cada lote na coluna U\$ / MEA.

TABELA 32 - Custo da pasta catalítica por MEA

\begin{tabular}{c|c|c|c|c|c}
\hline QUANT & PROC & $\begin{array}{c}\text { Eletrocat. } \\
\left(53,35 \cup \$ . g^{-1}\right)\end{array}$ & $\begin{array}{c}\text { Sol. Nafion }^{\circledR} \\
\left(0,31 \cup \$ . g^{-1}\right)\end{array}$ & $\begin{array}{c}\text { 2EEA } \\
\left(0,25 \cup \$ . g^{-1}\right)\end{array}$ & U\$ I MEA \\
\hline 1 & Spr & U\$ 61,46 & U\$ 3,84 & U\$ 0,00 & 65,30 \\
\hline 2 & Sie & U\$ 171,25 & U\$ 10,71 & U\$ 0,80 & 91,38 \\
\hline 4 & Sie & U\$ 299,99 & U\$ 18,77 & U\$ 1,41 & 80,04 \\
\hline 6 & Sie & U\$ 398,42 & U\$ 24,93 & U\$ 1,87 & 70,87 \\
\hline 8 & Sie & U\$ 475,88 & U\$ 29,78 & U\$ 2,23 & 63,49 \\
\hline
\end{tabular}

Observando os valores da coluna U\$ / MEA da TAB.32 sobre o custo da pasta catalítica por MEA, o processo de Aspersão (Spr) só apresentou valor maior que o lote de oito conjuntos produzidos por Impressão à Tela. Este fato ocorre em função do maior percentual de perda registrado pelo processo de 
Impressão à Tela em relação ao de Aspersão. Este percentual de perda só é atenuado no processo de Impressão à Tela caso sejam produzidas maiores quantidades de MEAs dentro de um mesmo lote.

Segundo os dados apresentados na TAB.32, o processo de Impressão à Tela torna-se uma opção economicamente viável em relação ao processo de Aspersão a partir de lotes de oito conjuntos produzidos, considerando somente os custos da pasta catalítica

O custo do tecido de carbono empregado no MEA é de 900,00 U\$.m² considerando a compra de 16 unidades de $0,25 \mathrm{~m}$ de largura por 0,25 $\mathrm{m}$ de comprimento da ETEK (B1A30WP - Carbon Cloth Designation A, com 30\% em massa de Teflon ${ }^{\circledR}$ ) /EPU08/. Neste valor não estão inclusas despesas com frete e impostos sobre a importação. São necessários $0,0288 \mathrm{~cm}^{2}$ por MEA deste tecido.

O valor do metro quadrado da membrana polimérica é de U\$1.360,00 considerando a compra de duas unidades com dimensões de 0,41 $\mathrm{m}$ de largura por 1,23 m de comprimento da membrana Nafion ${ }^{\circledR} \mathrm{N} 115$ /ONL08/, incluindo frete e sem impostos de importação. São necessários $0,0256 \mathrm{~m}^{2}$ desta membrana por MEA. O custo total dos componentes é apresentado na TAB.33

TABELA 33 - Custo total dos componentes por MEA

\begin{tabular}{|c|c|c|c|c|c|}
\hline QUANT & PROC & $\begin{array}{c}\text { Pasta } \\
(\mathrm{U} \$ / M E A)\end{array}$ & $\begin{array}{c}\text { Tec. Carb. } \\
\text { (U\$/MEA) }\end{array}$ & $\begin{array}{c}\text { Membrana } \\
\text { (U\$/MEA) }\end{array}$ & $\begin{array}{l}\text { TOTAL } \\
\text { (U\$/MEA) }\end{array}$ \\
\hline 1 & Spr & 65,30 & \multirow{5}{*}{25,92} & \multirow{5}{*}{34,82} & 126,04 \\
\hline 2 & Sie & 91,38 & & & 152,12 \\
\hline 4 & Sie & 80,04 & & & 140,78 \\
\hline 6 & Sie & 70,87 & & & 131,61 \\
\hline 8 & Sie & 63,49 & & & 124,23 \\
\hline
\end{tabular}

Para completar a comparação de custos entre os processos de fabricação, devemos acrescentar o custo relacionado ao tempo de produção dos lotes aos valores apresentados na coluna TOTAL da TAB.33. Esta componente tem influência sobre o custo da mão-de-obra por MEA além de afetar os custos relacionados com o maquinário utilizado. Todos os lotes produzidos despenderam um dia (oito horas) para serem concluídos, a diferença fica por conta do tamanho do lote e da quantidade de operadores. 
$\mathrm{Na}$ TAB.34 é mostrada uma simulação levando em consideração diferentes valores de salário de operadores ( $R \$ 1.000,00 ; R \$ 2.000,00$; $\mathrm{R} \$ 3.000,00$ e $\mathrm{R} \$ 4.000,00$ ) considerando um mês de trinta dias com jornada de oito horas. Os valores foram convertidos para dólar ( $U \$ 1,00=R \$ 2,00)$ e as simulações são apresentadas em U\$MEA.

TABELA 34 - Simulação de Custo (Ope - operadores; HH - homem-hora)

\begin{tabular}{|c|c|c|c|c|c|c|c|c|}
\hline \multirow[t]{2}{*}{ Quant } & \multirow[t]{2}{*}{ Proc } & \multirow[t]{2}{*}{ Ope } & \multirow{2}{*}{$\frac{\text { Horas }}{\text { MEA }}$} & \multirow[t]{2}{*}{$\mathrm{HH}$} & $\begin{array}{c}1.000,00 \\
\text { R\$/mês ou } \\
2,08 \text { U } \$ / h\end{array}$ & $\begin{array}{c}2.000,00 \\
\mathrm{R} \$ / \mathrm{mês} \text { ou } \\
4,16 \text { U\$/h }\end{array}$ & $\begin{array}{c}3.000,00 \\
\mathrm{R} \$ / \mathrm{mês} \text { ou } \\
6,25 \mathrm{U} \$ / \mathrm{h}\end{array}$ & $\begin{array}{c}4.000,00 \\
R \$ / m e ̂ s \text { ou } \\
8,32 \text { U\$/h }\end{array}$ \\
\hline & & & & & (U\$/MEA) & (U\$/MEA) & (U\$/MEA) & (U\$/MEA) \\
\hline 1 & Spr & 1 & 8 & 8 & 16,64 & 33,28 & 50,00 & 66,56 \\
\hline 2 & Sie & 1 & 4 & 4 & 8,32 & 16,64 & 25,00 & 33,28 \\
\hline 4 & Sie & 2 & 2 & 4 & 8,32 & 16,64 & 25,00 & 33,28 \\
\hline 6 & Sie & 2 & 1,33 & 2,66 & 5,53 & 11,06 & 14,56 & 22,12 \\
\hline 8 & Sie & 2 & 1 & 2 & 4,16 & 8,32 & 12,50 & 16,64 \\
\hline
\end{tabular}

Com estes cenários apresentados na TAB.34, a partir de um salário de $\mathrm{R} \$ 2.000,00$ mensais, ou $\cup \$ 4,16$ a hora, por operador, a produção de um lote de quatro MEAs, com dois operadores, por Impressão à Tela (157,42 U\$/MEA) é mais econômica que a confecção destes com um operador no processo de Aspersão (159,32 U\$/MEA).

As projeções de tamanho de lote e as simulações de custo de mão-deobra serviram para identificar que o processo de Impressão à Tela pode tornar-se economicamente viável em relação ao processo de Aspersão mesmo para pequenos lotes de produção.

Um MEA comercial similar (A-7 ELAT ${ }^{\circledR}$ V2.1 Hand Fabricated, Double Sided Coatings - confeccionado com membrana Nafion 115, eletrocatalisador $20 \%$ Pt em Vulcan XC-72, com carga de $0,5 \mathrm{mg} \cdot \mathrm{cm}^{-2}$ por eletrodo, com aplicação de ionômero na camada catalítica e com ELAT nos dois lados do tecido de carbono) é vendido a U $\$ 272,59$ o de $100 \mathrm{~cm}^{2}$ e por U $\$ 500,83$ o de $225 \mathrm{~cm}^{2}$ /EPU08/, o que torna a produção por Impressão à Tela uma opção economicamente viável para o IPEN.

Para que possa haver um levantamento mais completo sobre o custo de produção deve-se levar em conta o investimento inicial da máquina de Impressão à Tela $(U \$ 60.000,00)$ e os custos associados a sua operação e 
manutenção. É recomendável, que no futuro seja conduzido um estudo para identificar a formação de "Lotes Econômicos" para diferentes tamanhos e geometrias de MEA considerando todas as parcelas de contribuição do custo operacional. 


\section{CONCLUSÕES}

Durante o desenvolvimento do processo de Impressão à Tela para confecção de MEAs de células do tipo PEM, foi necessária a introdução de diversos procedimentos técnicos para a execução do processo com sucesso:

(1) Constatou-se a importância do prévio tratamento térmico da membrana que facilitou a pintura no processo de Impressão à Tela para áreas ativas de $25 \mathrm{~cm}^{2}$ evitando-se seu enrugamento. Para área de $144 \mathrm{~cm}^{2}$, o efeito também foi benéfico, porém adicionou-se a utilização de um dispositivo com uma armação vazada no centro.

(2) Na produção de grandes quantidades de pasta catalítica, a tinta com adição de solução 2:1 de água e 2-[2 Ethoxyethoxy] Ethyl Acetate - 2EEA - foi ideal para o processo de Impressão à Tela. O uso de atmosfera de gás inerte durante o processo de evaporação no preparado da pasta diminuiu o risco de combustão.

(3) O procedimento de secagem sob lâmpadas foi a melhor solução para se manter a membrana lisa e propícia para receber diversas camadas de um mesmo eletrodo durante o processo de Impressão à Tela. Ao utilizar um peso sobre a membrana durante a secagem sob lâmpada o efeito de enrugamento da membrana foi minimizado. Além disso, a regra de deposição mostrou-se uma boa prática operacional para lotes de produção de MEAs de $144 \mathrm{~cm}^{2}$. A produção por uma pessoa só foi possível devido ao uso da regra de deposição limitando, porém o tamanho do lote ou aumentando o tempo de produção.

(4) O processo de prensagem a quente utilizando placas de $(15,1 \times 15,1) \mathrm{cm}^{2}$ a $444,33 \mathrm{kgf} . \mathrm{cm}^{-2}$ por 5 minutos para MEAs de $144 \mathrm{~cm}^{2}$ alcançou o grau de aderência desejado entre camada difusora e camada catalítica. Esta prática permitiu que os conjuntos não descolassem durante operação.

Desenvolvido o método de Impressão à Tela, os eletrodos confeccionados apresentaram uma camada catalítica mais coesa e homogênea do que os conjuntos fabricados por Aspersão, embora a adesão da camada catalítica à membrana seja similar para os dois processos de pintura.

Os dois processos, Aspersão e Impressão à Tela, foram capazes de produzir MEAs com desempenhos acima de $600 \mathrm{~mA} \cdot \mathrm{cm}^{-2}$ a $600 \mathrm{mV}$ para 
conjuntos com $25 \mathrm{~cm}^{2}$ de área ativa. O MEA de $25 \mathrm{~cm}^{2}$ que apresentou o melhor desempenho (760 mA.cm a $600 \mathrm{mV}$ e $14,26 \mathrm{~W}$ a $33 \mathrm{~A}$ ) foi fabricado por Impressão à Tela utilizando tinta com solução de Nafion $5 \%$ em massa e solvente. Os dois métodos apresentaram excelente reprodutibilidade de resultados. A variação de carga não gerou influência significativa no desempenho da célula de $25 \mathrm{~cm}^{2}$ de área ativa.

Os dois perfis desenvolvidos para os testes dos MEAs de $144 \mathrm{~cm}^{2}$ apresentaram bons resultados utilizando-se simulação por FDC. O perfil quadrado desenvolvido apresentou menor área de estagnação e o perfil trapezoidal resultou em velocidades sempre maiores que zero. A célula unitária de $144 \mathrm{~cm}^{2}$ projetada demonstrou bom desempenho alcançando densidades de corrente acima de $300 \mathrm{~mA} . \mathrm{cm}^{-2}$ a $600 \mathrm{mV}$ com MEAs de 0,4:0,4 mgPt.cm ${ }^{-2}$.

Os desempenhos dos MEAs de $144 \mathrm{~cm}^{2}$ produzidos neste trabalho ficaram abaixo dos resultados obtidos pelo melhor conjunto comercial utilizado para comparação. Porém, os MEAs comerciais apresentavam camada difusora ELAT dos dois lados do tecido de carbono enquanto os MEAs de fabricação própria utilizaram tecido de carbono com $30 \%$ de Teflon ${ }^{\circledR}$. Estas diferenças entre os conjuntos foram as prováveis responsáveis pela discrepância em desempenho.

Observou-se que um MEA comercial similar pode apresentar um preço de venda até $100 \%$ maior do que o custo da produção própria, o que torna a produção por Impressão à Tela uma opção viável para o Programa de Células a Combustível do IPEN e passível de transferência para a indústria nacional. Neste caso, recomenda-se a produção por batelada, a fim de se minimizar perdas.

Concluindo, foi desenvolvido um processo inédito no Brasil de confecção de conjuntos eletrodos-membrana, por Impressão à Tela, com baixo custo e capaz de obter MEAs de bom desempenho, adequado para a construção de pequenos módulos de potência, objetivo principal deste trabalho. 


\subsection{Sugestões para trabalhos posteriores}

Novos trabalhos poderiam abordar o uso de outras composições da pasta catalítica, visando melhorar o desempenho do MEA. Pesquisas sobre o tratamento químico do $\mathrm{MEA}$ com $\mathrm{HNO}_{3}$ podem levantar informações relevantes sobre o impacto desta atividade no desempenho da célula.

Como sugestão para estudo, a pintura sobre tecido de carbono pode ser implementada tanto para deposição de camada catalítica como para deposição de camada difusora (similar ao ELAT). Além disso, o emprego de um tecido de carbono com outros percentuais de Teflon $^{\circledR}$, a utilização de uma camada difusora ELAT comercial e a deposição de menores cargas de componentes nobres podem colaborar para a melhoria do desempenho do MEA em operação ou para a redução do custo do conjunto eletrodo-membrana-eletrodo.

Com a percepção de que a redução da espessura da parede dos canais de distribuição de gás melhora o desempenho da célula, outros perfis poderiam ser submetidos à simulação por FDC, por exemplo, o perfil triangular. Para obter um estudo de simulação mais completo deve-se considerar ainda os efeitos das reações químicas, do contato elétrico e da compressão do GDL.

Em trabalhos posteriores, poder-se-ia estudar o projeto de placas estruturais com funções de arrefecimento. Outra sugestão de melhoria ao projeto Célula Unitária é o uso de anéis de vedação entre a placa de cobre e a de grafite.

Para aproveitar a versatilidade da máquina de Impressão à Tela, o estudo da confecção de MEAs de diferentes geometrias poderia ser abordado em algum trabalho posterior a este.

Estudos de confiabilidade poderiam ser conduzidos para verificar o comportamento dos MEAs produzidos, por exemplo, experimentos de longa duração visando à obtenção de dados de durabilidade dos MEAs.

Por fim, recomenda-se que seja conduzido um estudo para identificar a formação de "Lotes Econômicos" para diferentes tamanhos e geometrias de MEA considerando todas as parcelas de contribuição do custo operacional. 
APÊNDICE A - Máquina de Impressão à Tela

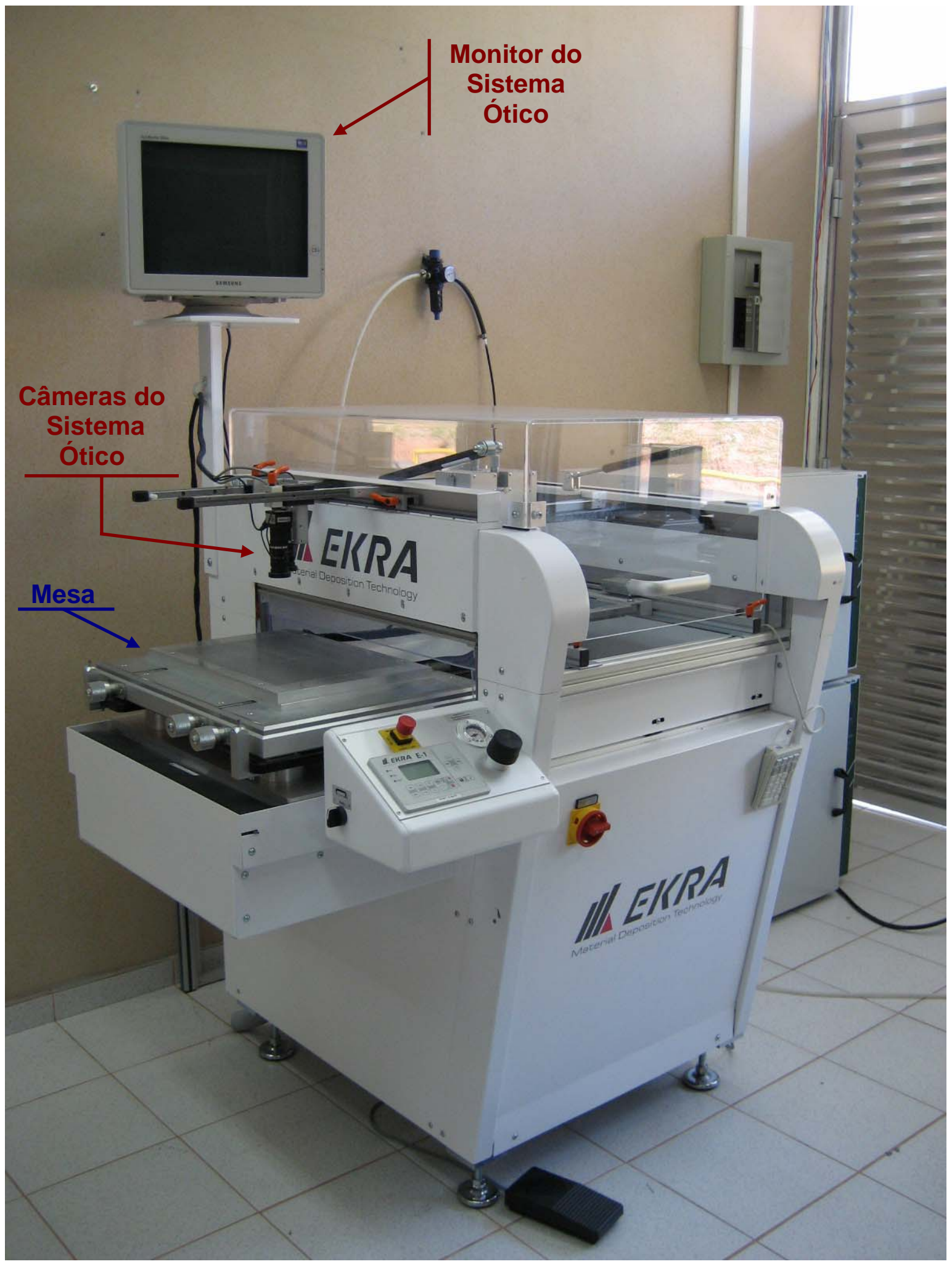


APÊNDICE B - Resultados do perfil PQ20

$\mathrm{P}(\mathrm{Pa})$ para $\mathrm{y}=3,50 \mathrm{~mm}$

Max: 1148.108
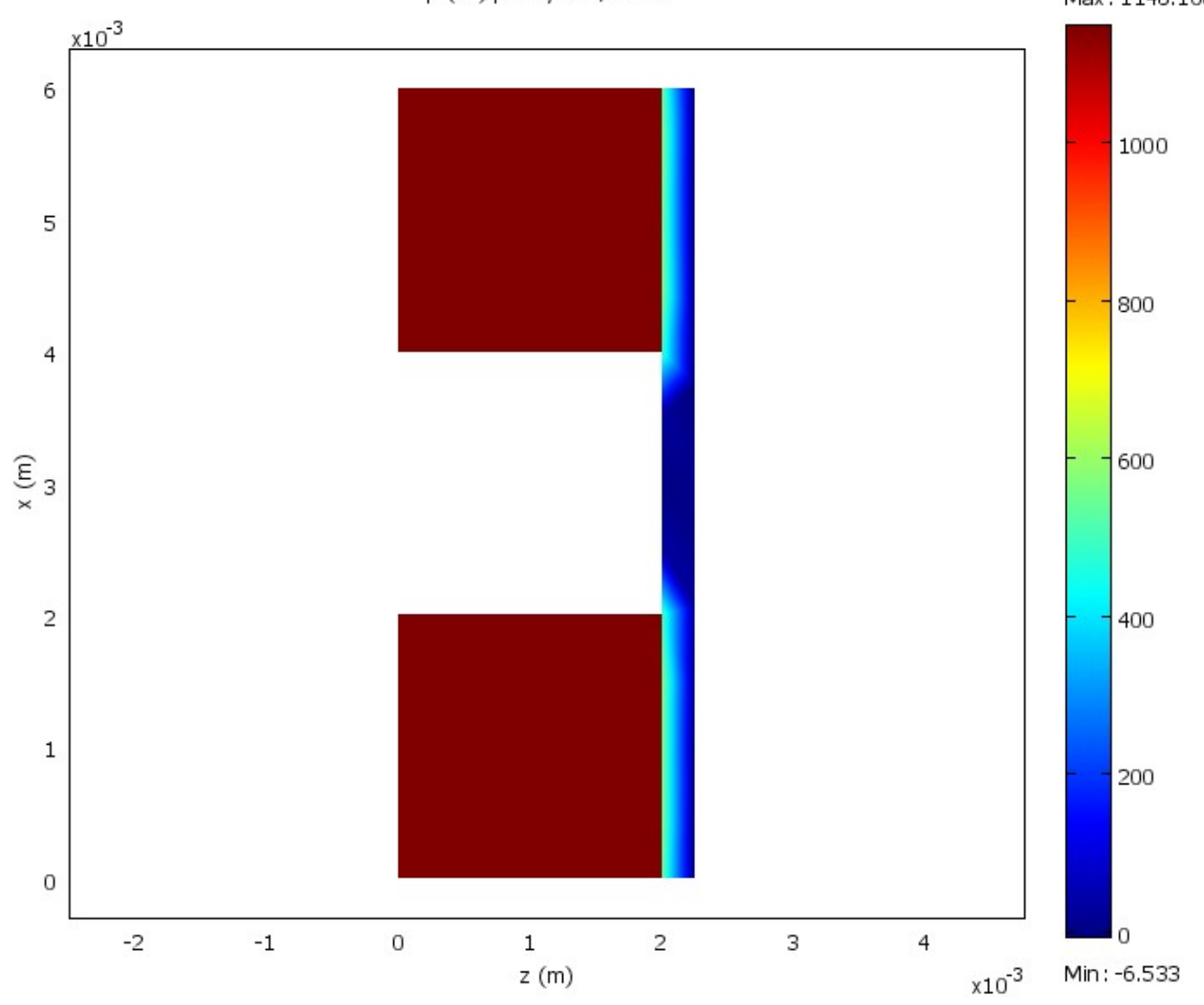

$\mathrm{w}(\mathrm{m} / \mathrm{s})$ para $=3,50 \mathrm{~mm}$

Max : 0.363
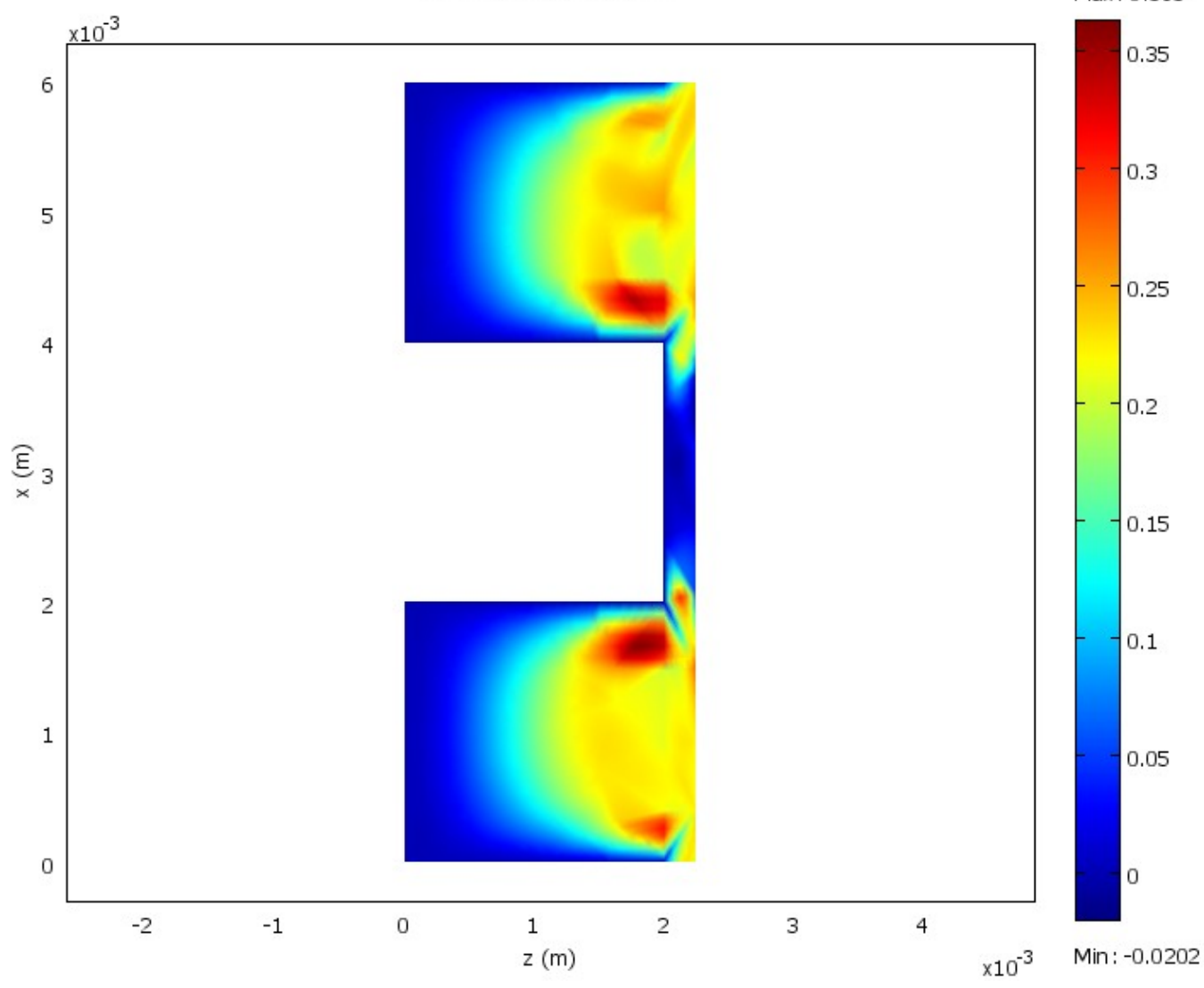
APÊNDICE C - Resultados do perfil PQ15

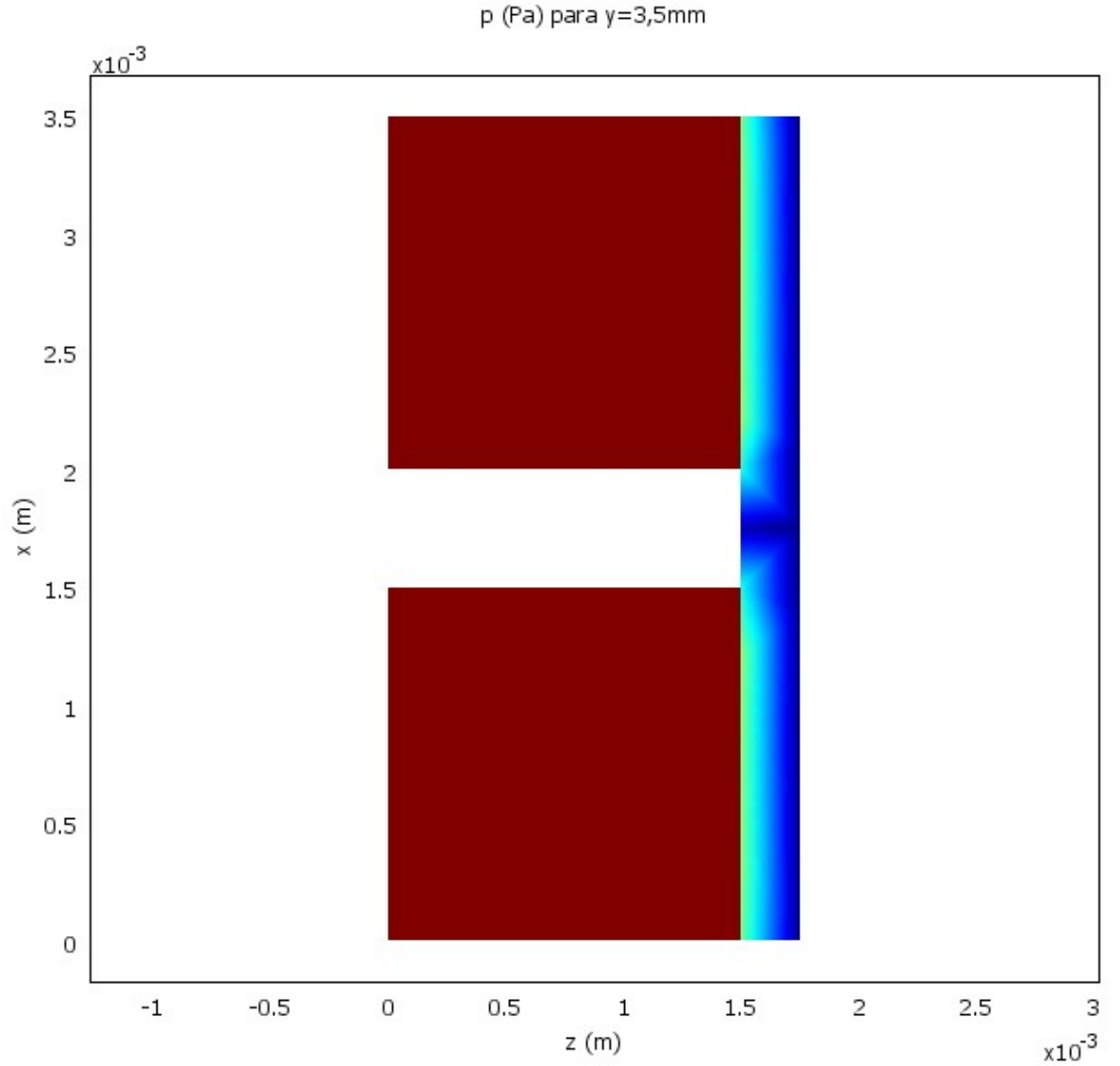

Max : 1334.93
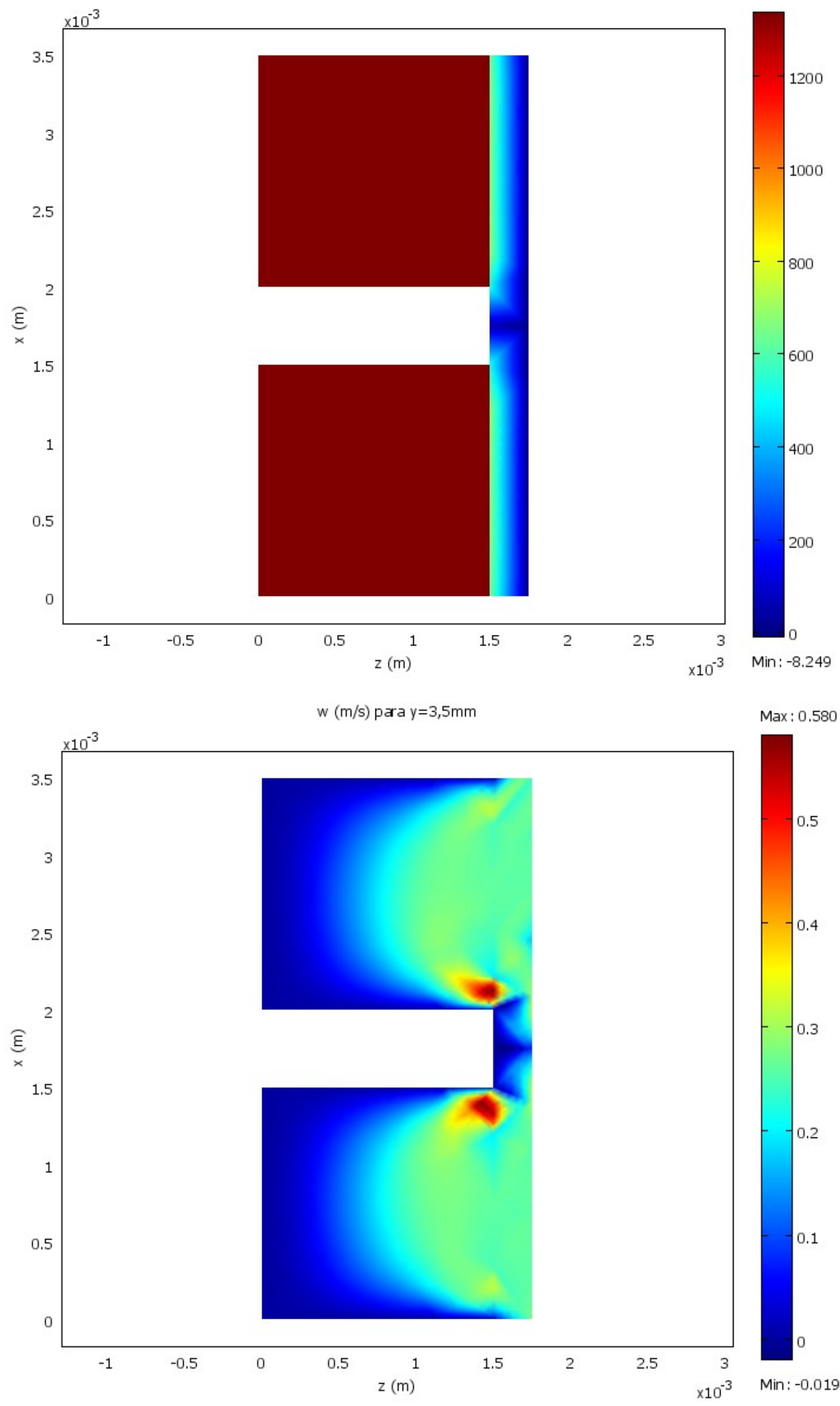

Max : 0.580

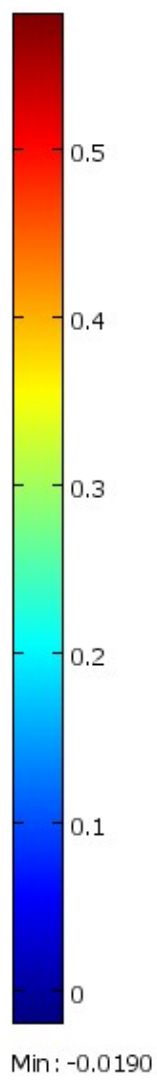




\section{APÊNDICE D - Resultados do perfil PT}

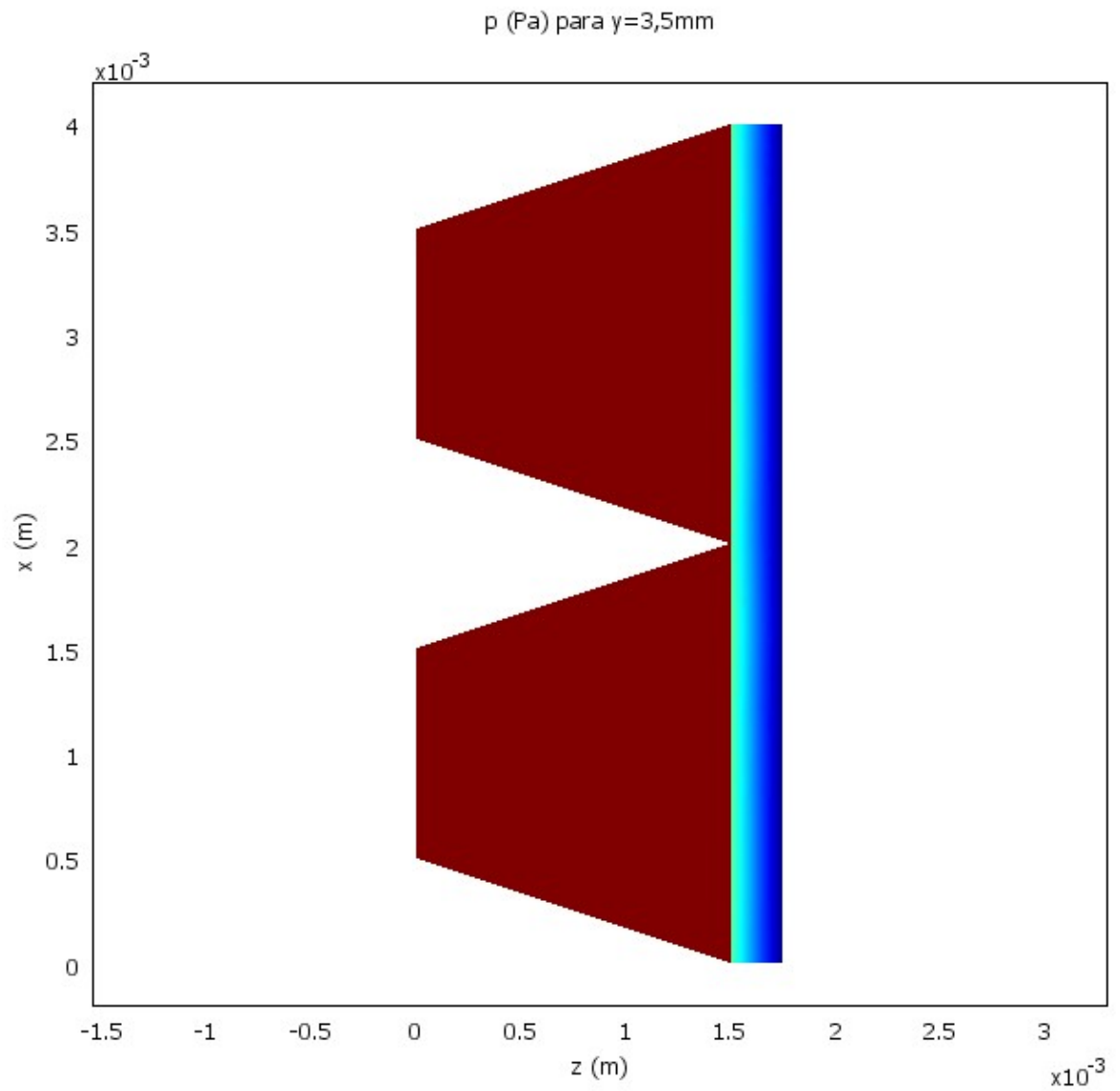

Max : 1103.881

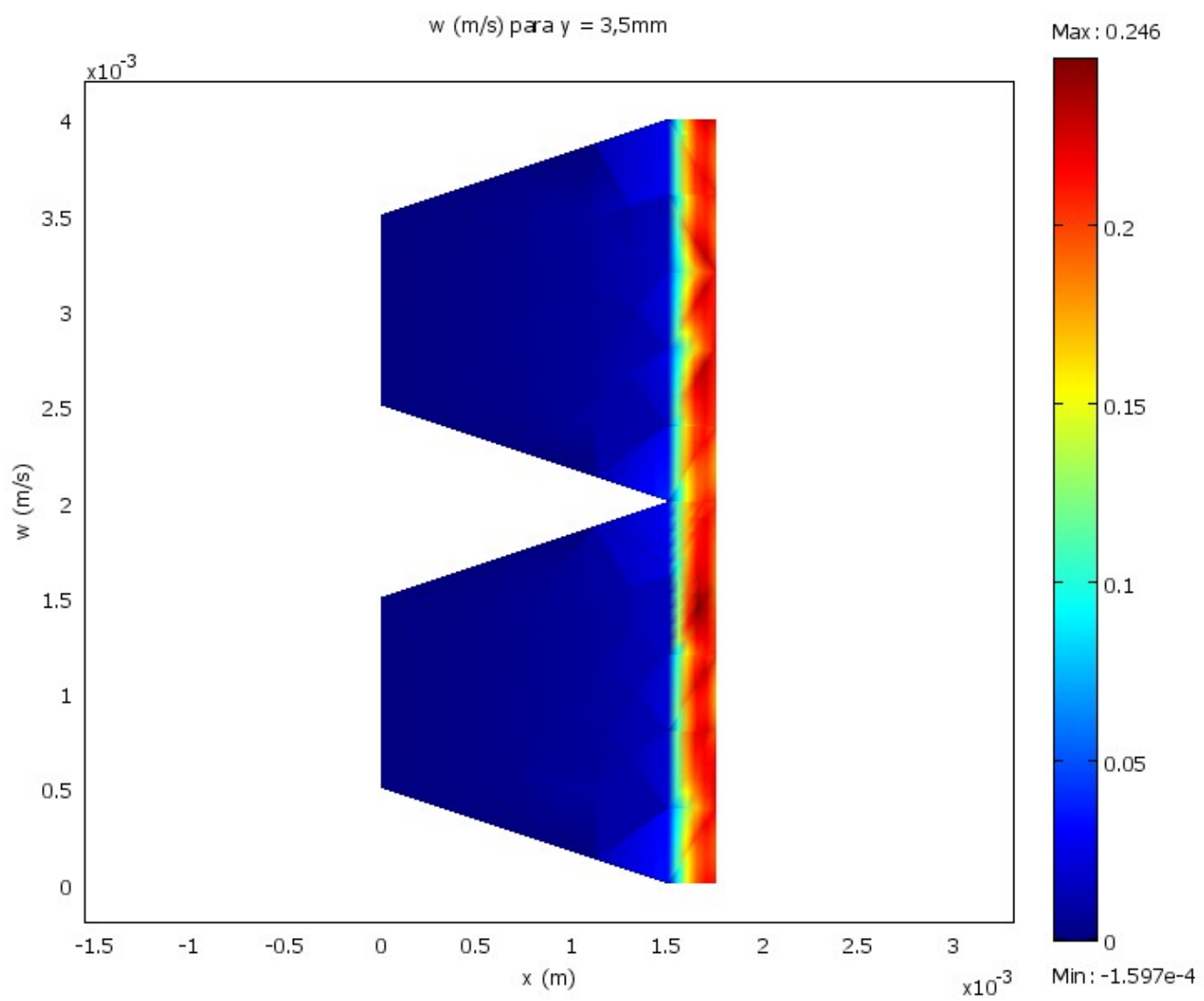


APÊNDICE E - Vista Frontal - Grafite - Perfil Quadrado

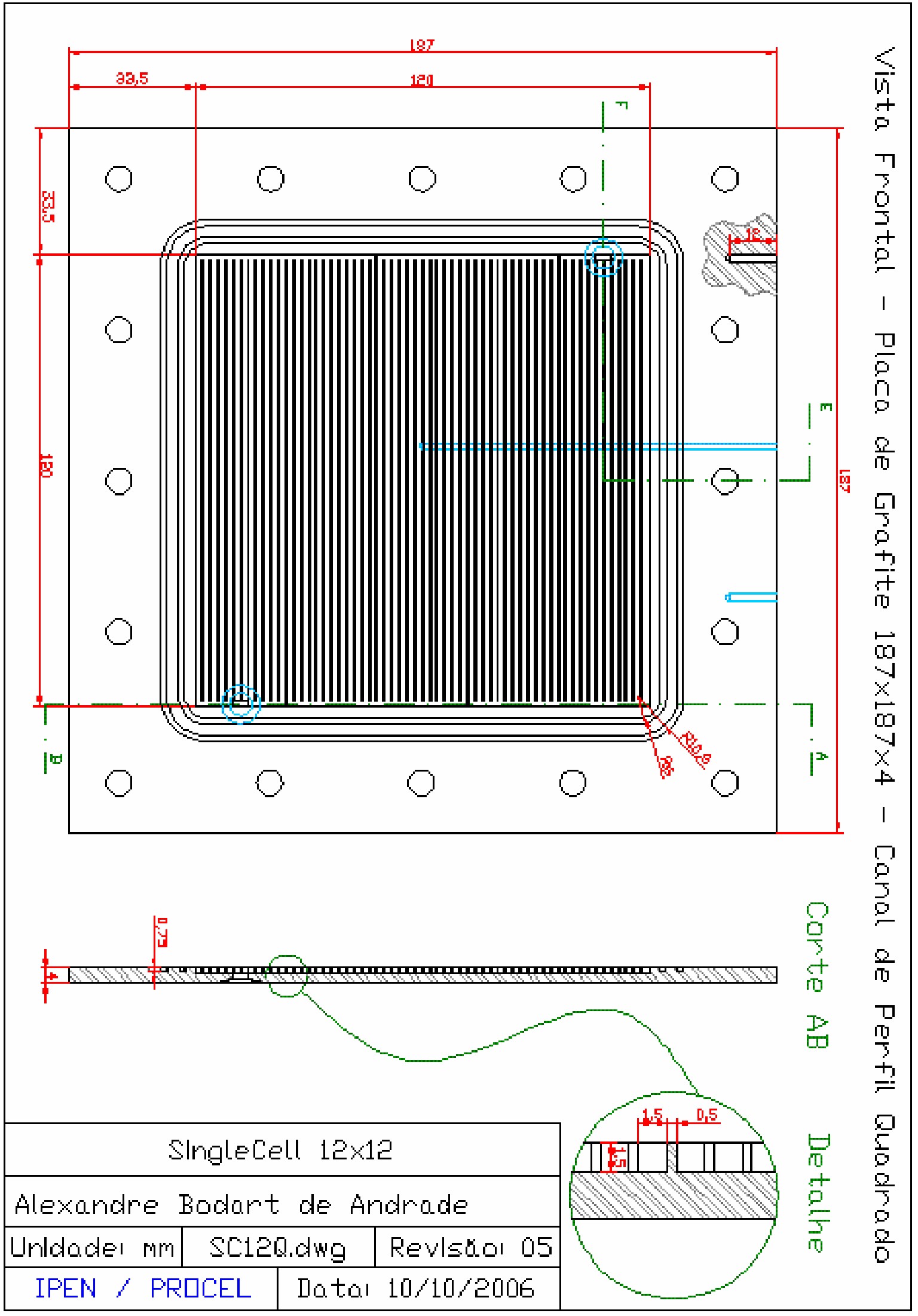


APÊNDICE F - Vista Posterior - Grafite - Perfil Quadrado

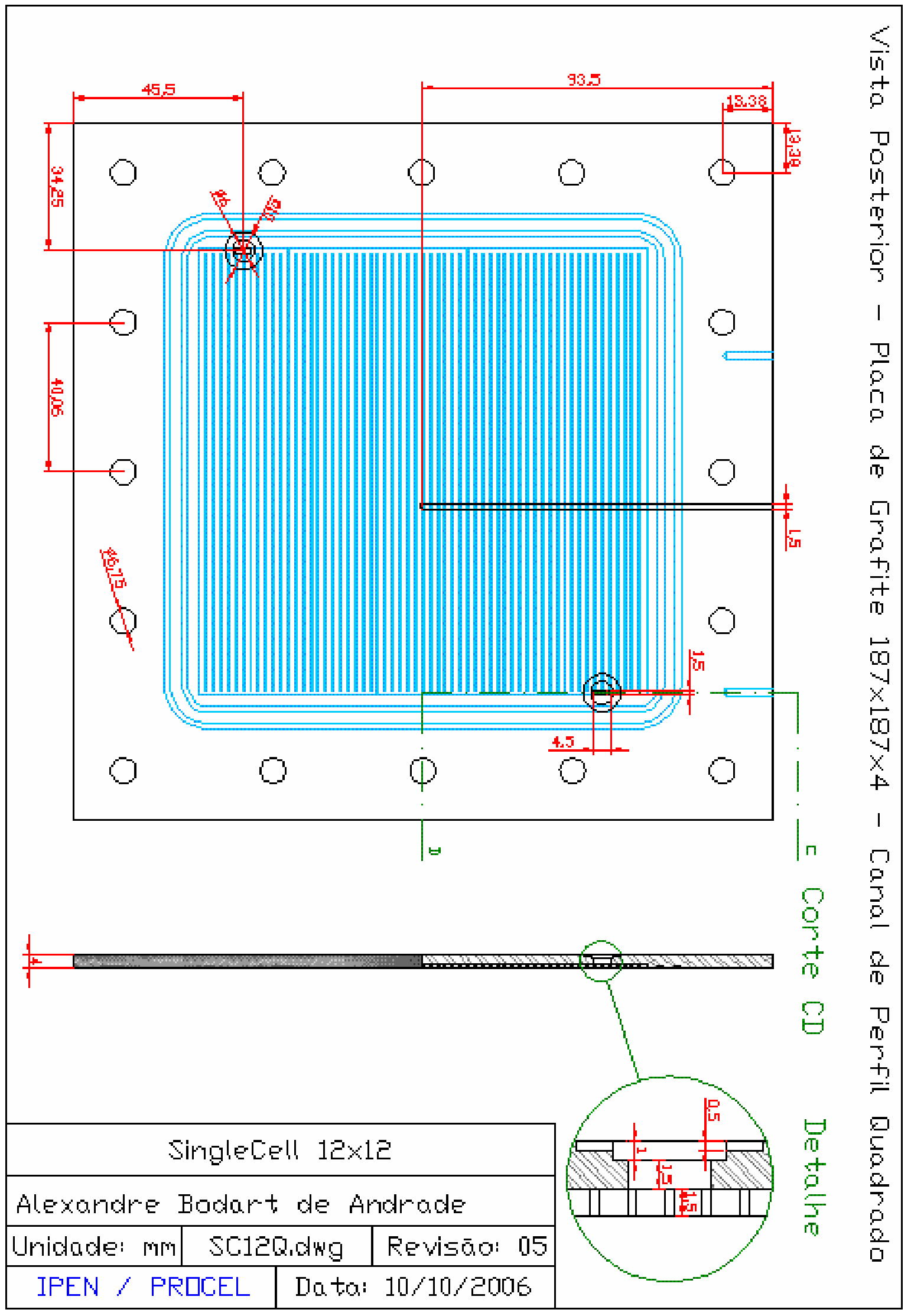


APÊNDICE G - Vista de Topo - Grafite - Perfil Quadrado

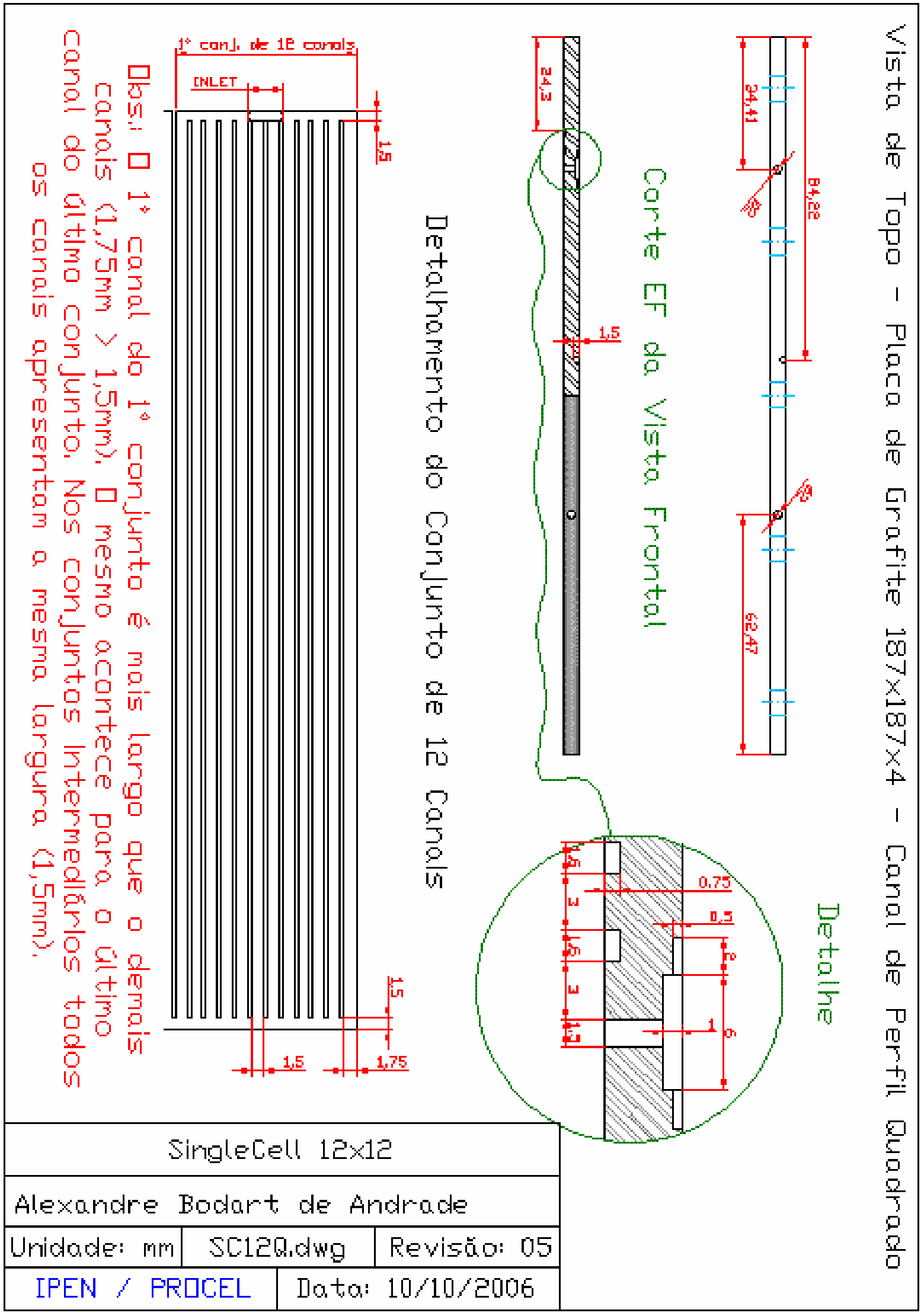


APÊNDICE H - Vista Frontal - Grafite - Perfil Trapezoidal

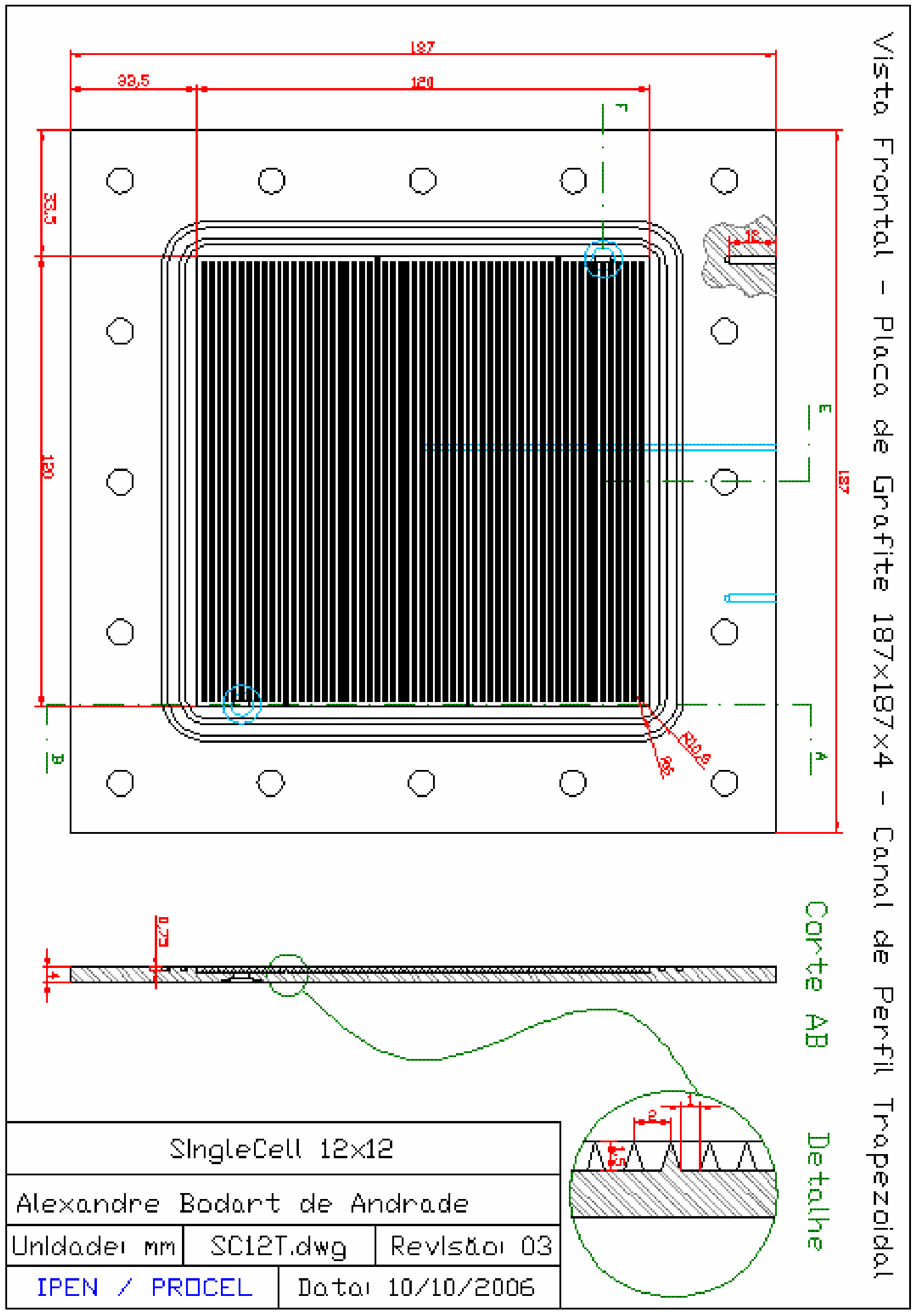


APÊNDICE I - Vista Posterior - Grafite - Perfil Trapezoidal

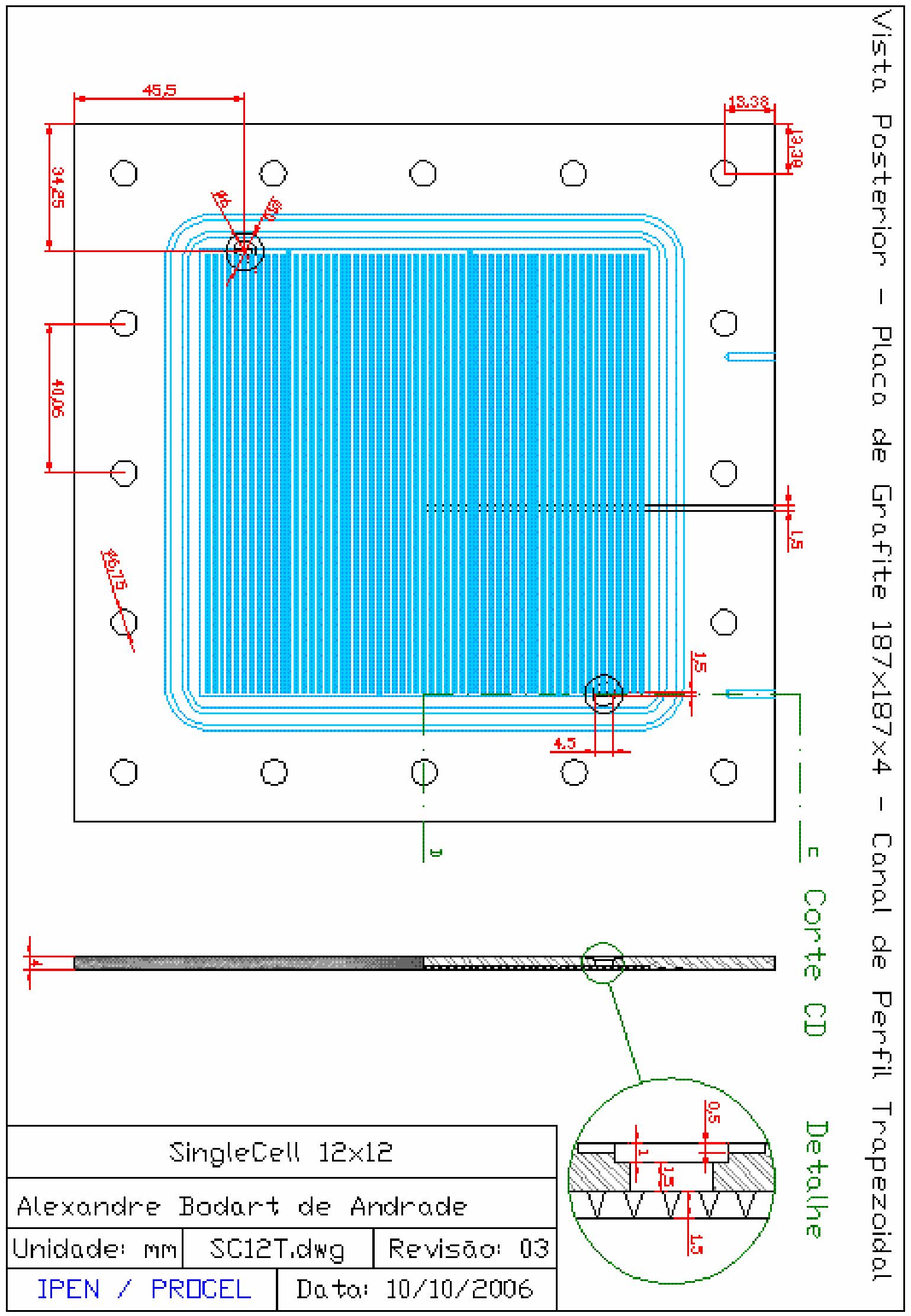


APÊNDICE J - Vista de Topo - Grafite - Perfil Trapezoidal

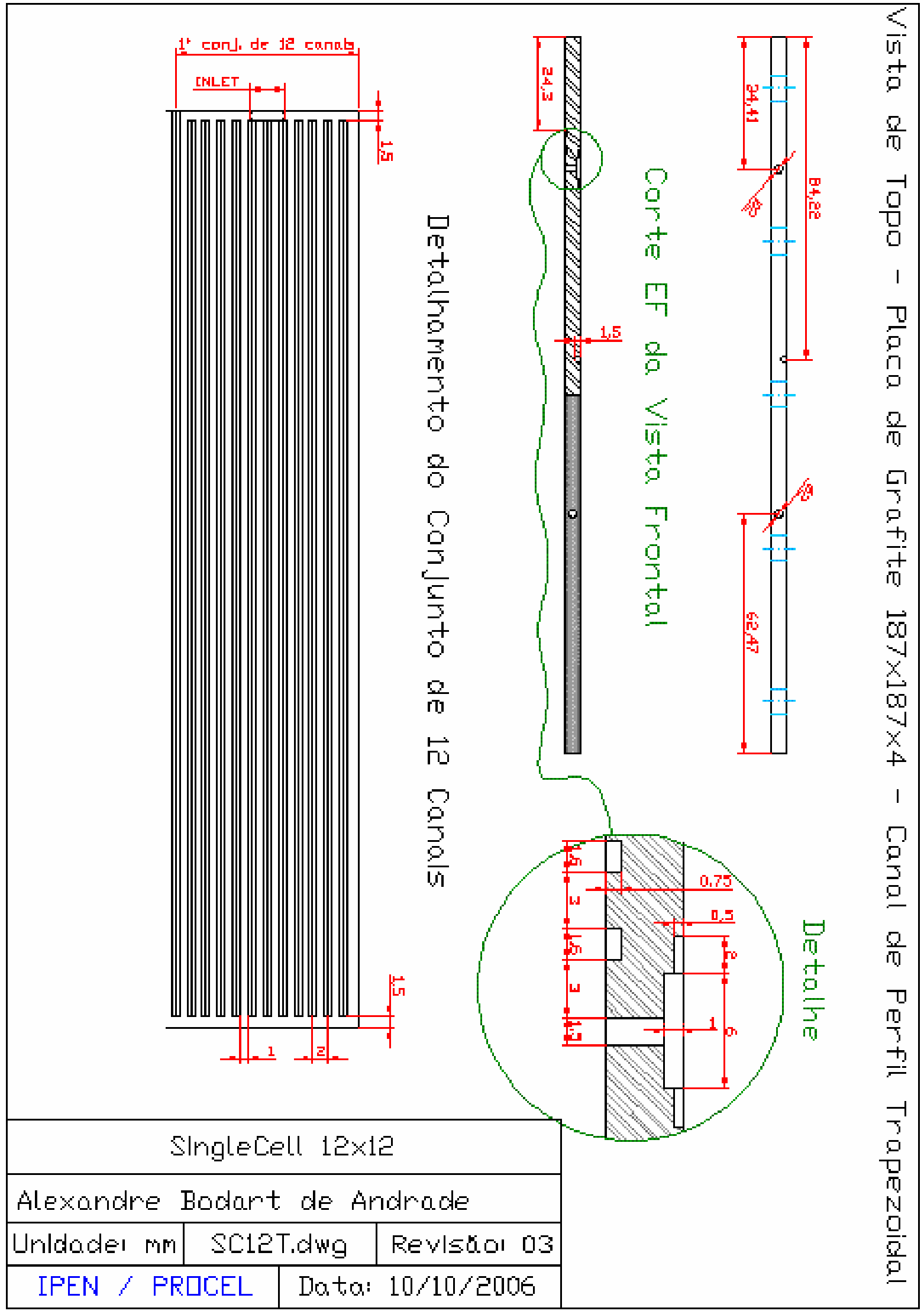


APÊNDICE K - Vista Frontal - Cobre

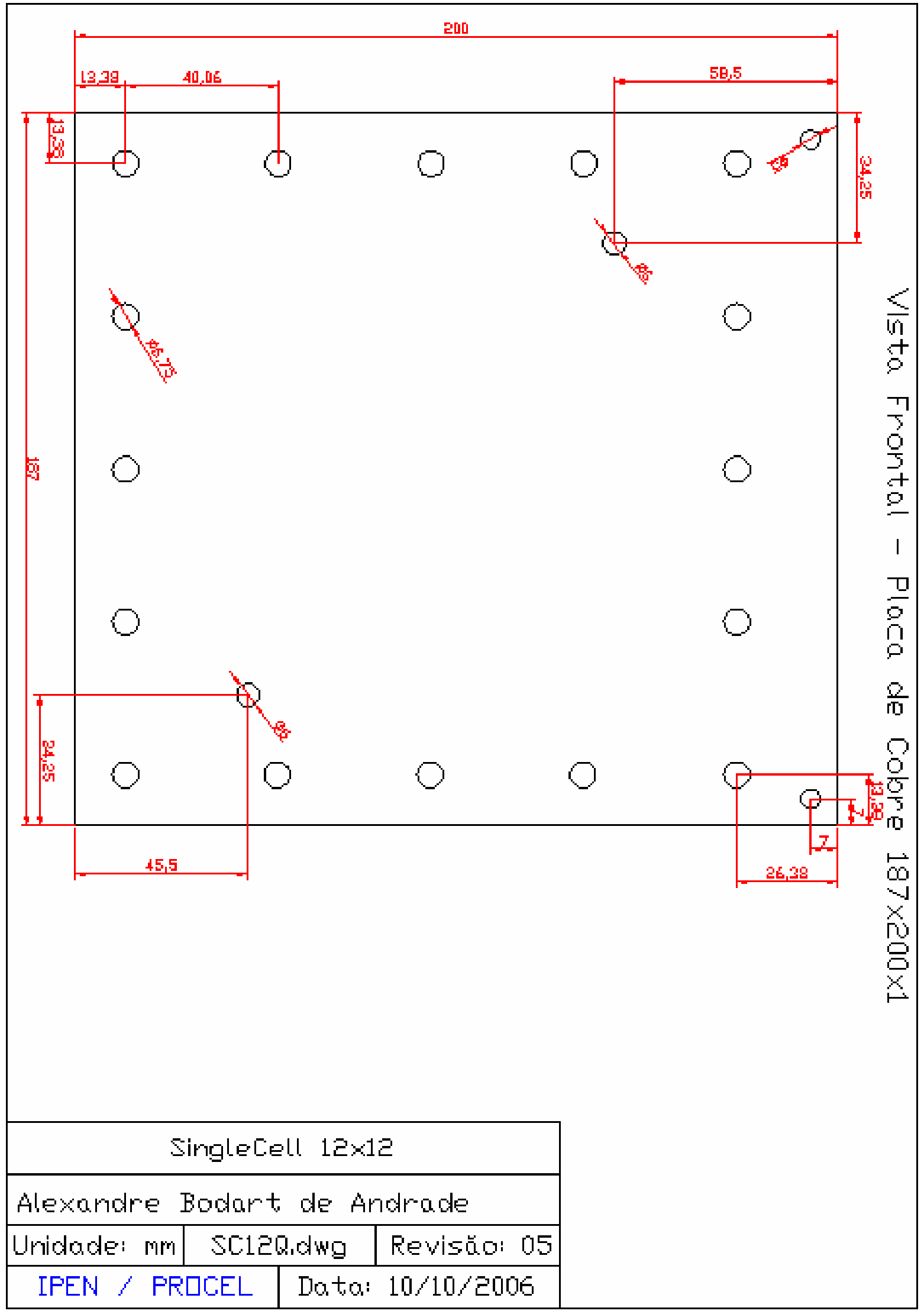


APÊNDICE L - Vista Frontal - Alumínio

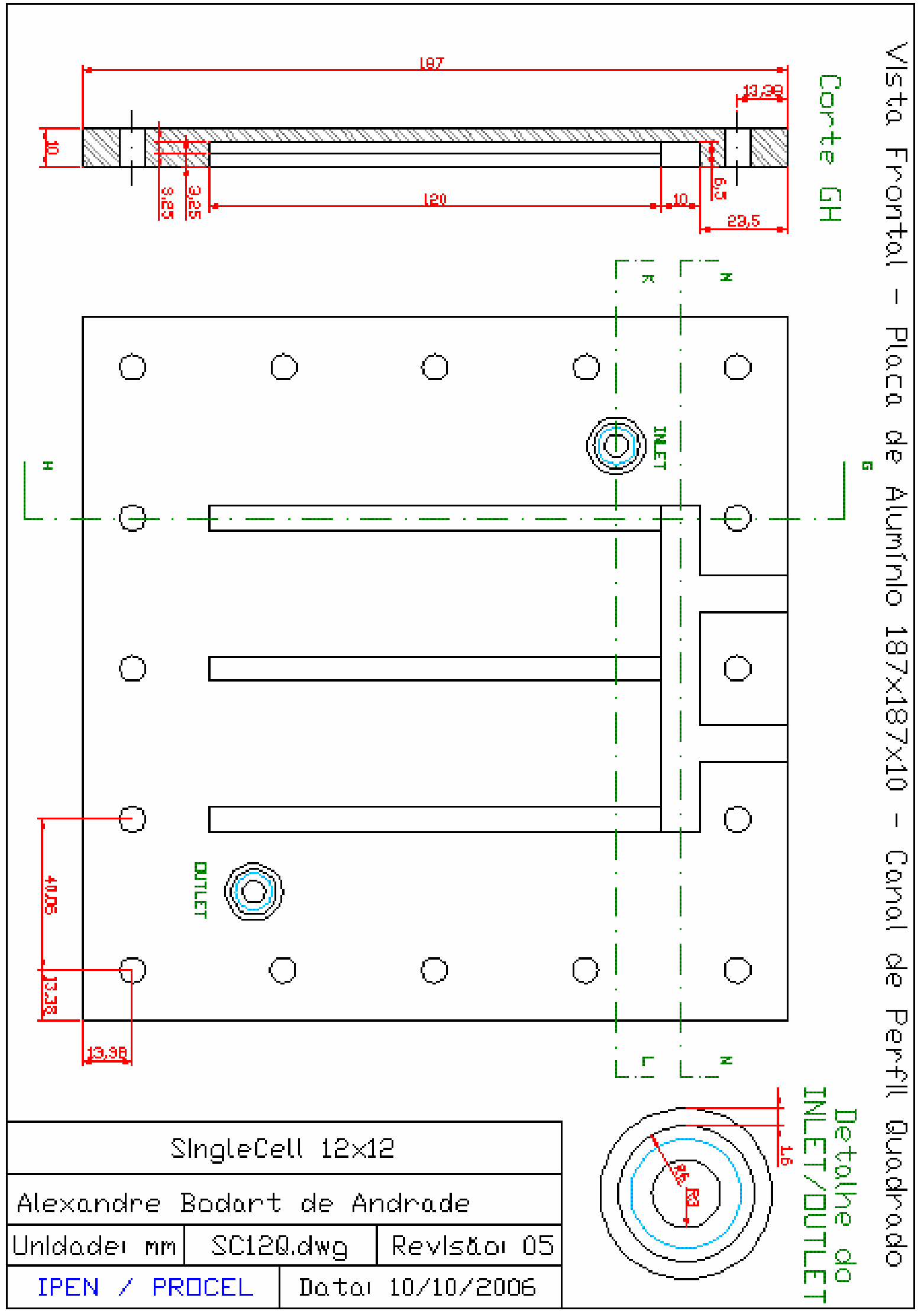


APÊNDICE M - Vista Posterior - Alumínio

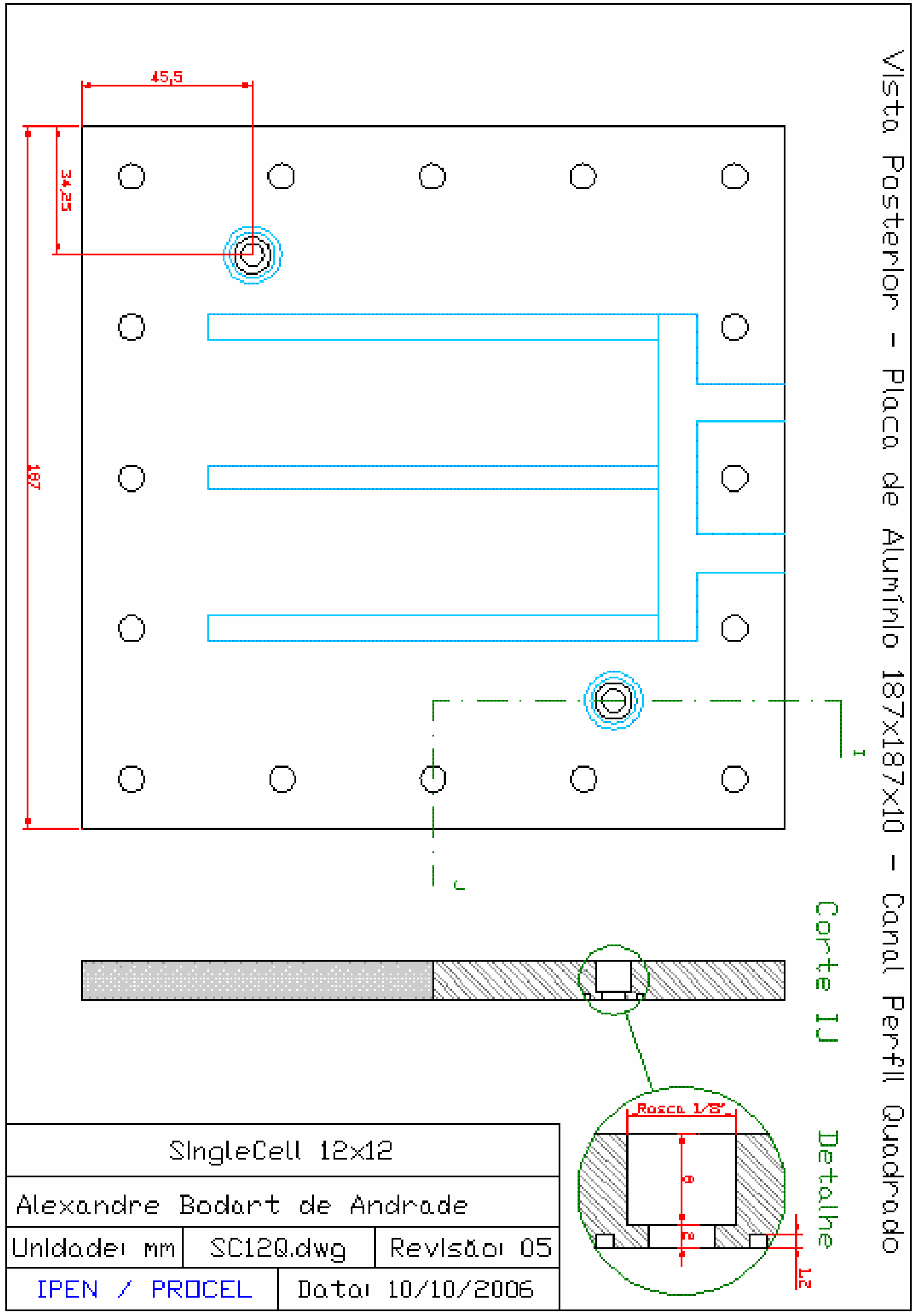


APÊNDICE N - Vista de Topo - Alumínio

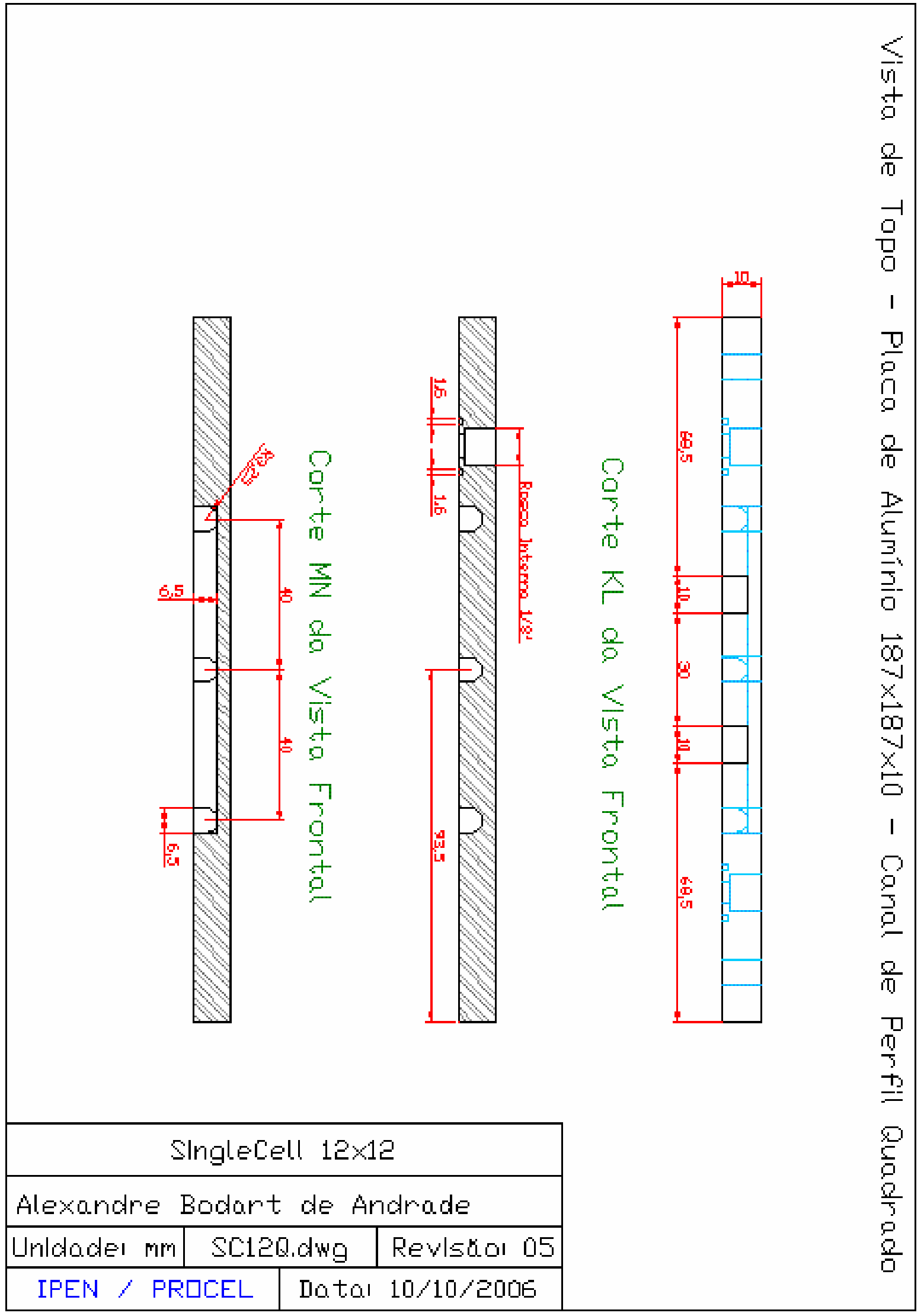


APÊNDICE O - Montagem

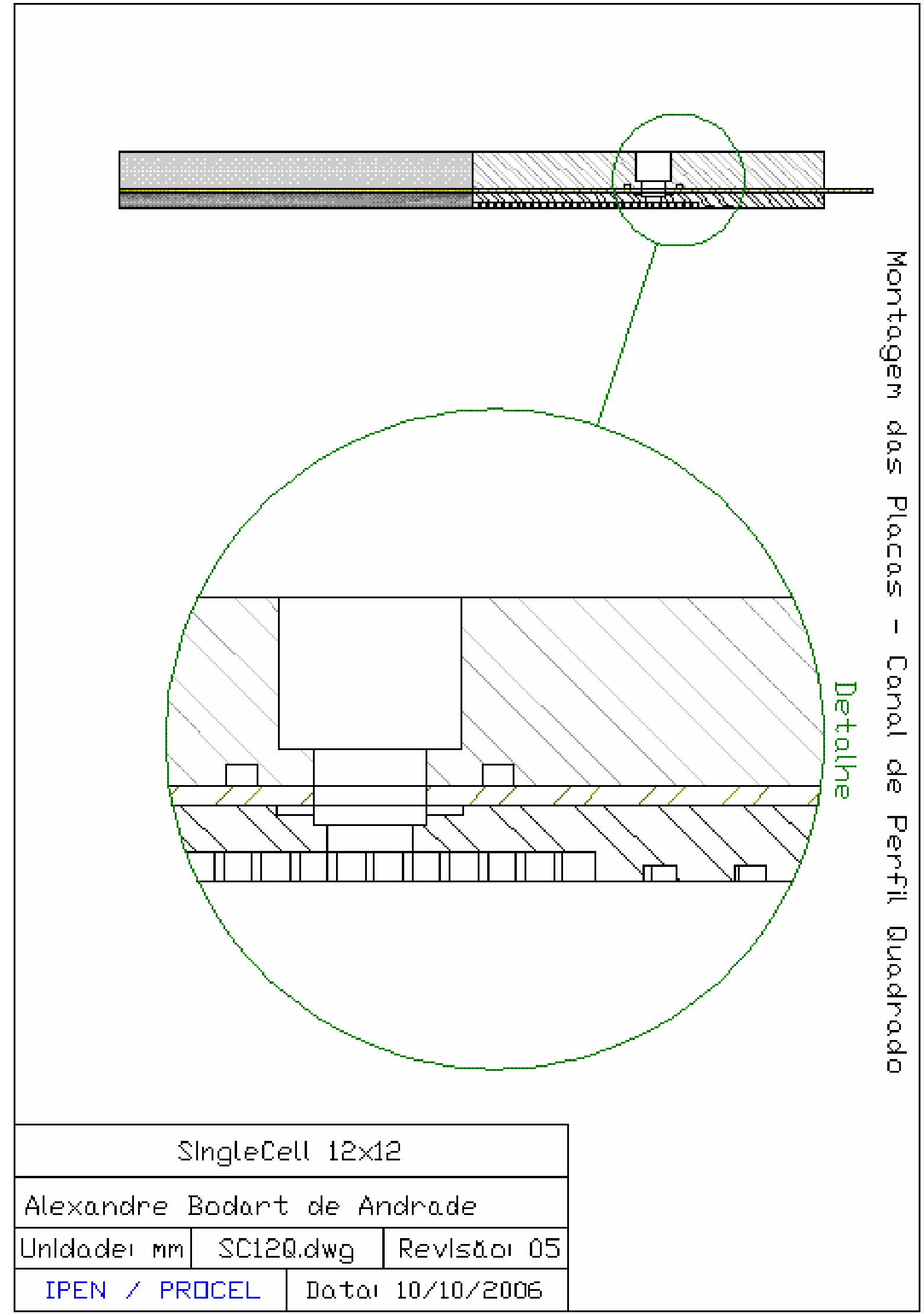




\section{GLOSSÁRIO}

Ativação: processo operacional que visa alcançar o estado de melhor desempenho de um MEA recém confeccionado.

Polarização: afastamento do potencial de operação em relação ao potencial de equilíbrio em função da passagem de corrente elétrica em um eletrodo.

Trabalhabilidade: propriedade que apresenta um material de ser facilmente preparado e aplicado. 


\section{REFERÊNCIAS BIBLIOGRÁFICAS}

/BAL03/ BALDO, W.R. Desenvolvimento de um método de preparação de conjuntos eletrodo-membrana-eletrodo para células a combustível a membrana trocadora de prótons (PEMFC). 2003. Dissertação (Mestrado) - Instituto de Pesquisas Energéticas e Nucleares, São Paulo.

/CLE97/ CLEOGHORN, S.J.C.; REN, X.; SPRINGER, T.E.; WILSON, M.S.; ZAWODZINSKI, C.; ZAWODZINSKI, T.A.; GOTTESFELD, S. PEM fuel cells for transportation and stationary power generation applications. International Journal of Hydrogen Energy, v. 22, n. 12, p. 1137-1144, 1997.

/DEF04/ DE FRANCESCO, M.; ARATO, E.; COSTA, P. Transport phenomena in membranes for PEMFC applications: an analytical approach to the calculation of membrane resistance. Journal of Power Sources, v. 132, p. 127-134, 2004.

/DEG99/ DEGUSSA AKTIENGESELLSCHAFT. A. Fischer; H. Wendt; R. Zuber. Gas diffusion electrode for membrane fuel cells and method of its production. US Pat. 5.861.222; 19 jan. 1999.

/GWE07/ GWENT Eletronic Materials Ltd. Produzido por Alan Hobby, 1997. Apresenta texto sobre o processo de impressão à tela. Disponível em: $<$ http://www.g-e-m.com/info/indust/indust.html $>$. Acesso em: 12 jul. 2007.

/DOW99/ DOW CHEMICAL COMPANY. R. D. Mussell. Electrode ink for membrane electrode assembly. US Pat. 5.869.416; 09 fev. 1999.

/ECK04/ ECKL, R.; ZEHTNER, W.; LEU, C.; WAGNER, U. Experimental analysis of water management in a self-humidifying polymer electrolyte fuel cell stack. Journal of Power Sources, v. 138, p. 137-144, 2004.

/EPU08/ EPURCHASE PRODUCT. E-TEK Division. Disponível em: $<$ http://www.etek-inc.com/epurchase/purchase A.php?prodid=8>. Acesso em: 25 jun. 2008.

/FRE01/ FREIRE, T.J.P.; GONZALEZ, E.R. Effect of membrane characteristics and humidification conditions on the impedance response of polymer electrolyte fuel cells. Journal of Electroanalytical Chemistry, v. 503, p. 57-68, 2001.

/FRE04/ FREY, T.; LINARDI, M. Effects of membrane electrode assembly preparation on the polymer electrolyte membrane fuel cell performance. Electrochimica Acta, v. 50, p. 99-105, 2004. 
/JOH99/ JOHNSON MATHEY PUBLIC LIMITED Co. Frost et al. Manufacture of electrodes. US Pat. 5.871.860; 16 fev. 1999.

/KAL08/ KALOW \& SPRINGUT LLP. W. Behl; M. Lopez. Ink for Producing Catalyst Layers. US Pat. 20080191161; 14 ago. 2008.

/KIM98/ KIM, C.S.; CHUN, Y.G.; PECK, D.H.; SHIN, D.R. A novel process to fabricate membrane electrode assemblies for proton exchange membrane fuel cells. International Journal of Hydrogen Energy, v. 23, n. 11, p. 1045-1048, 1998.

/KUM02/ KUMAR, A.; REDDY, R.G. Effect of channel dimensions and shape in the flow-field distributor on the performance of polymer electrolyte membrane fuel cells. Journal of Power Sources, v. 113, p. 11-18, 2002.

/LIT04/ LITSTER, S.; MCLEAN, G. PEM fuel cell electrodes. Journal of Power Sources, v. 130, p. 61-76, 2004.

/ONL08/ ONLINE STORE. Ion Power, Inc. Disponível em: <http://store.ionpower.com/>. Acesso em: 25 jun. 2008.

ISAR03/ SARTORI, R.A. Desenvolvimento de protótipos de células a combustível de $\mathrm{H}_{2} / \mathrm{O}_{2}$ de 500 e 1.000 W; estudos e Experimentos em células unitárias com catalisadores obtidos por processo solgel para oxidação direta de etanol. 2003. Tese (Doutorado) - Instituto de Química de São Carlos, USP, São Carlos.

ISTA96/ STASCHEWSKI, D. Internal humidifying of PEM fuel cells. International Journal of Hydrogen Energy, v. 21, n. 5, p. 381-385, 1996.

/TIC05/ TICIANELLI, E.A.; GONZALEZ, E.R. Cinética dos processos eletródicos. In: TICIANELLI, E.A.; GONZALEZ, E.R. Eletroquímica: princípios e aplicações. 2.ed. São Paulo, SP: Editora da Universidade de São Paulo, 2005. p. 77-126.

/TOW07/ TOWNE,S.; VISWANATHAN, V.; HOLBERY, J.; RIEKE, P. Fabrication of polymer electrolyte membrane fuel cell MEAs utilizing inkjet print technology. Journal of Power Sources, v. 171, p. 575-584, 2007.

/UNI89/ UNITED STATES DEPARTAMENT OF ENERGY. I. D. Raistrick. Electrode assembly for use in a solid polymer electrolyte fuel cell. US Pat. 4.876.115; 24 out. 1989.

/UNI93/ UNIVERSITY OF CALIFORNIA. M. S. Wilson. Membrane catalyst layer for fuel cells. US Pat. 5.234.777; 10 ago. 1993. 
/WENO0/ WENDT, H.; GÖTZ, M.; LINARDI, M. Tecnologia de Células a Combustível. Química Nova, 23 (4), p.538-546, 2000.

IWIL04/ WILLIAMS, M.V.; KUNZ, H.R.; FENTON, J.M. Operation of Nafion ${ }^{\circledR}-$ based PEM fuel cells with no external humidification: influence of operating conditions and gas diffusion layers. Journal of Power Sources, v. 135, p. 122-134, 2004.

/YAN05/ YAN, Q.; TOGHIANI, H.; WU, J. Investigation of water transport through membrane in a PEM fuel cell by water balance experiments. Journal of Power Sources, aceito em 06/09/2005, a ser publicado, no prelo.

/YOS05/ YOSHIOKA, S.; YOSHIMURA, A.; FUKUMOTO, H.; HIROI, O.; YOSHIYASU, $\mathrm{H}$. Development of a PEFC under low humidified conditions. Journal of Power Sources, v. 144, p. 146-151, 2005. 